$$
\begin{aligned}
& \text { UNIVERSIDADE DE SÃO PAULO } \\
& \text { INSTITUTO DE GEOCIÊNCIAS }
\end{aligned}
$$

\title{
ENSAIOS TRIAXIAIS MULTI-ESTÁGIOS EM SOLO RESIDUAL
}

\author{
MARIANE BORBA DE LEMOS \\ Orientador: Prof. Dr. Fernando Antônio Medeiros Marinho
}

\section{Dissertação de Mestrado}

Programa de Pós-Graduação em Recursos Minerais e Hidrogeologia

SÃO PAULO

2019 

UNIVERSIDADE DE SÃO PAULO

INSTITUTO DE GEOCIÊNCIAS

ENSAIOS TRIAXIAIS MULTI-ESTÁGIOS EM SOLO RESIDUAL

Mariane Borba de Lemos

Dissertação apresentada ao Programa de Pós-Graduação em Recursos Minerais e Hidrogeologia para a obtenção do título de Mestre em Ciências

Orientador: Prof. Dr. Fernando Antônio Medeiros Marinho 
Autorizo a reprodução e divulgação total ou parcial deste trabalho, por qualquer meio convencional ou eletrônico, para fins de estudo e pesquisa, desde que citada a fonte.

Serviço de Biblioteca e Documentação do IGc/USP

Ficha catalográfica gerada automaticamente com dados fornecidos pelo(a) autor(a) via programa desenvolvido pela Seção Técnica de Informática do ICMC/USP

Bibliotecários responsáveis pela estrutura de catalogação da publicação: Sonia Regina Yole Guerra - CRB-8/4208 | Anderson de Santana - CRB-8/6658

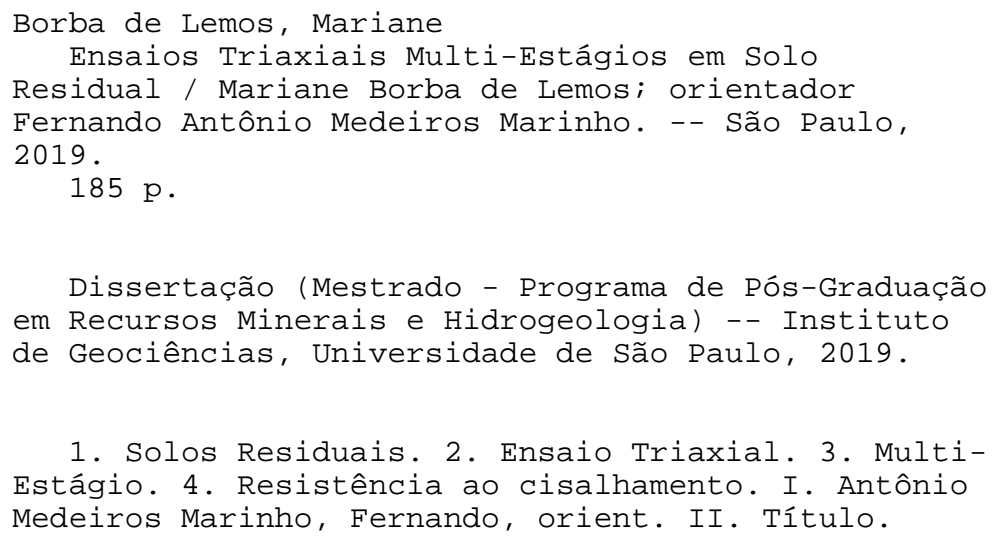


À minha avó Lourdes e à minha irmã Marina, que tanto me marcaram e que gostariam de saber que consegui chegar até aqui. 



\section{AGRADECIMENTOS}

Gostaria de expressar os meus sinceros agradecimentos a todos aqueles que participaram e que tornaram possível a realização da presente pesquisa.

À Universidade de São Paulo e a todos os professores do Instituto de Geociências pela oportunidade de aprendizagem e pelos conhecimentos essenciais à minha formação pessoal e profissional.

Ao professor Fernando Marinho pela oportunidade, pela orientação impecável e pela presença constante em todas as etapas da pesquisa, mostrando-se sempre disponível para auxílios, trocas de ideias e discussões.

Aos técnicos de laboratório do LMS, Antônio e Joaquim por todos os auxílios e ensinamentos, fundamentais para realização dos ensaios realizados.

À empresa Egis Engenharia, em nome do Engenheiro Carlos e do Técnico Gilberto, por permitir a utilização de sua estrutura e pelo apoio constante durante a execução dos ensaios triaxiais.

Aos colegas Carla e Robert, pela companhia e pela ajuda nos momentos iniciais da pesquisa, que foram fundamentais para o meu desenvolvimento.

Ao Tiago Manzolli, por toda a ajuda no desenvolvimento deste trabalho e, principalmente, por todo o carinho, companheirismo e compreensão nos momentos de dificuldade.

À toda a minha família, em especial aos meus pais, Janaína e Hamilton, pelo apoio financeiro, pelo amor e pela compreensão, sem os quais eu não conseguiria vencer este desafio. 

“Guarde sempre na lembrança que esta estrada não é sua Sua vista pouco alcança, mas a terra continua" A estrada e o violeiro - Sidney Miller 



\section{RESUMO}

LEMOS, M.B, 2019, Ensaios Triaxiais Multi-Estágios em Solo Residual [Dissertação de Mestrado], São Paulo, Instituto de Geociências, Universidade de São Paulo, 186 p.

Em projetos geotécnicos, a determinação dos parâmetros de deformabilidade e resistência ao cisalhamento é fundamental para a previsão do comportamento de um solo frente aos métodos construtivos escolhidos. Neste contexto, a adoção da técnica multi-estágio em ensaios triaxiais pode ser uma boa ferramenta na otimização de projetos, uma vez que utiliza apenas um corpo de prova para a determinação destes parâmetros, reduzindo os custos e o tempo de ensaio. Nesta técnica, um único corpo de prova é submetido à três estágios de cisalhamento, em tensões confinantes distintas, sem que a tensão de resistência seja totalmente mobilizada até o último estágio do teste. Tendo em vista o elevado potencial prático e econômico desta técnica, esta pesquisa tem o objetivo de avaliar sua aplicação em um solo residual jovem de elevada heterogeneidade. Para tanto, foram realizados ensaios triaxiais multi-estágios e convencionais em amostras compactadas e indeformadas e as trajetórias de tensões, os parâmetros de resistência e de deformabilidade obtidos foram comparados. Também foram realizadas análises em microscópio eletrônico de varredura (MEV), a fim de analisar o efeito dos estágios sucessivos de cisalhamento na estrutura do corpo de prova. Observou-se que os parâmetros de resistência obtidos em ensaios multi-estágios apresentam boa correlação com os obtidos em ensaios convencionais, nas amostras indeformadas. Porém, nos ensaios realizados em amostras compactadas, os corpos de prova apresentaram comportamentos distintos, com ganho de resistência nos estágios finais. Em relação aos parâmetros de deformabilidade, notou-se que os obtidos em ensaios multi-estágios são compatíveis com aqueles obtidos em ensaios convencionais, após atingir certo nível de deformação. Nas imagens de MEV, foi possível observar a formação de um plano de ruptura em um corpo de prova que foi cisalhado apenas até o pico da tensão desviadora. Já nos ensaios convencionais realizados, a elevada heterogeneidade do solo dificultou a moldagem de corpos de prova compatíveis e a interpretação dos parâmetros de resistência. Dessa forma, conclui-se que a técnica multi-estágio é válida para a obtenção dos parâmetros de resistência para este solo em amostras indeformadas e, em casos de elevada heterogeneidade, está técnica pode apresentar resultados mais coerentes do que aqueles obtidos na técnica convencional, uma vez que não é necessário interpolar dados obtidos em amostras distintas.

Palavras-chave: solos residuais, ensaio triaxial, multi-estágio, resistência ao cisalhamento 



\begin{abstract}
LEMOS M.B, 2019, Multistage Triaxial Testing of Residual Soil [Master Thesis], São Paulo, Institute of Geosciences, University of São Paulo, 186 p.

The determination of deformability and shear strength parameters is fundamental for the behavior prediction of a soil considering the construction methods in geotechnical projects. The adoption of the multistage technique in triaxial tests may be a good tool in the optimization of projects, it uses only one test body for the determination of these parameters, reducing costs and test time. In this technique, a single specimen is subjected to three shear stages, at distinct confining stresses, without the full mobilization of the stress strength until the last stage of the test. Considering the practical and economic potential of this technique, this research aims the evaluation of its application in a highly heterogeneous residual soil. In order to do so, we performed multistage and conventional triaxial tests on compacted and undeformed samples, and the tensile trajectories and shear strength and deformability parameters obtained were compared. Scanning Electron Microscopy (SEM) analysis were also performed to study the effect of successive shear stages on the structure of the specimen. It was observed that the shear strength parameters obtained in multistage tests present good correlation with those obtained through conventional tests of undisturbed samples. However, in the tests carried out on compacted samples, the specimens presented different behaviors, resulting in poorly correlated resistance parameters. Regarding the parameters of deformability, it was noticed that the results of the multistage tests were compatible with the ones obtained in conventional tests, after reaching a certain level of deformation. In the SEM images, it was possible to observe the formation of a failure plane in a specimen that was sheared up to the peak of the deviator stress. In the conventional tests, the high soil heterogeneity made it difficult to mold compatible test bodies and to interpret the shear strength parameters. Therefore, it is concluded that the multistage technique is valid for the obtention of shear strength parameters for undisturbed samples of this soil. Furthermore, in cases of high heterogeneity, the multistage technique can provide more accurate results than the ones obtained in the conventional technique.
\end{abstract}

Keywords: residual soils, triaxial test, multi-stage, shear strength 



\section{SUMÁRIO}

RESUMO

\section{ABSTRACT}

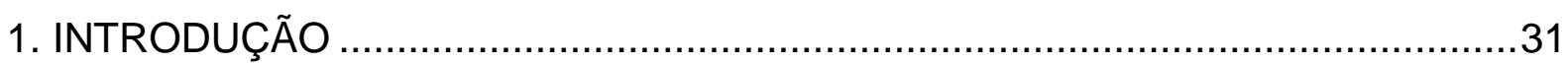

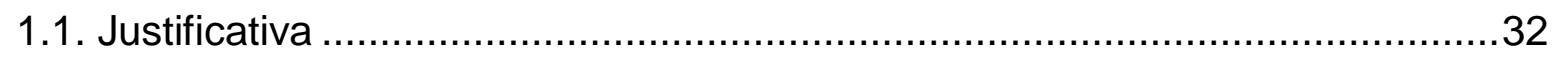

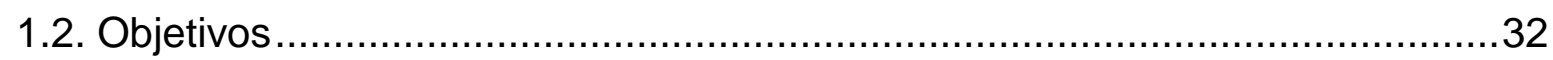

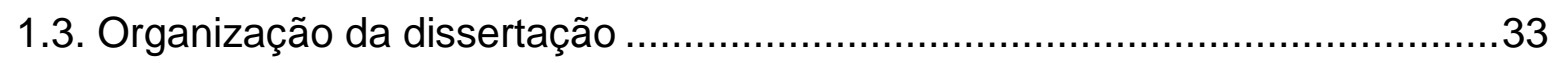

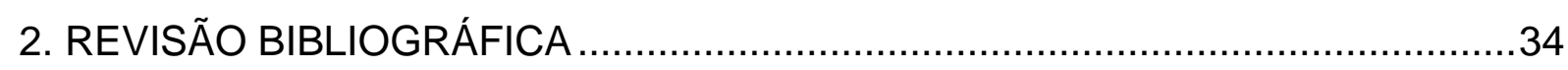

2.1. Resistência ao Cisalhamento de Solos.........................................................34

2.1.1. Ensaio de compressão triaxiais convencional .......................................35

2.1.2. Critérios para determinação da resistência ao cisalhamento em ensaios

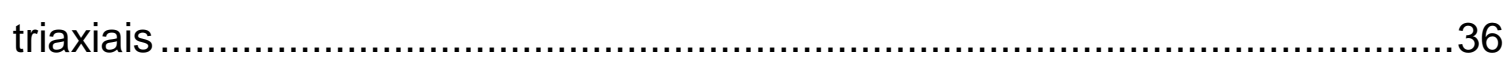

2.2. Zonas de Cisalhamento e Mecanismos de Ruptura em Solos ........................38

2.2.1. Microestruturas típicas de uma zona de cisalhamento............................40

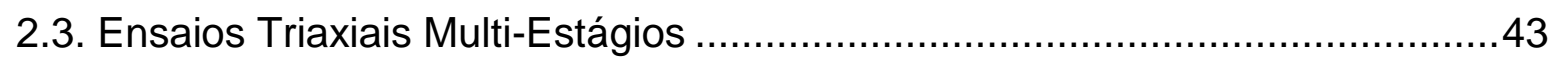

2.3.1. Metodologia de execução de ensaios triaxiais multi-estágios ..................44

2.3.2. Resultados da literatura e suas interpretações .......................................54

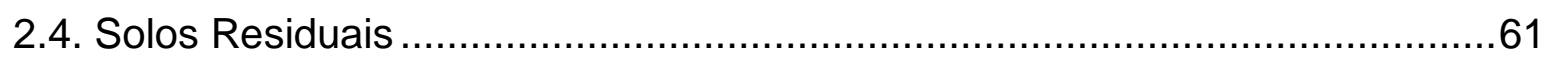

2.4.1. Resistência ao cisalhamento de solos residuais ...................................62

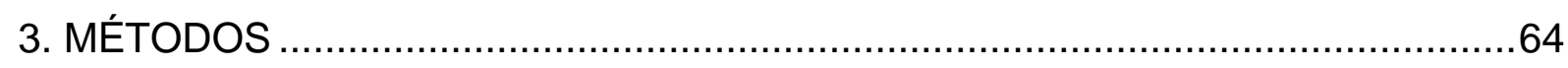

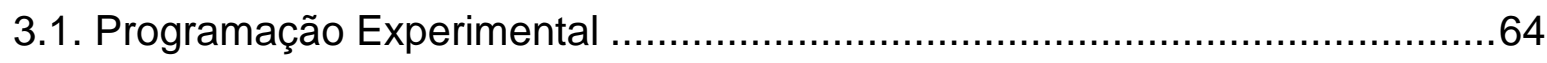

3.2. Retirada de Amostras e Armazenamento …….............................................66

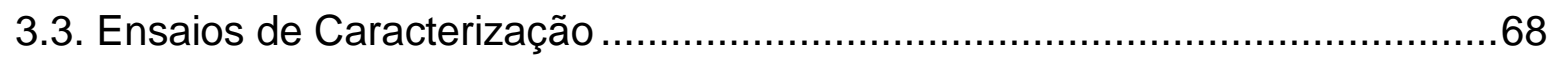

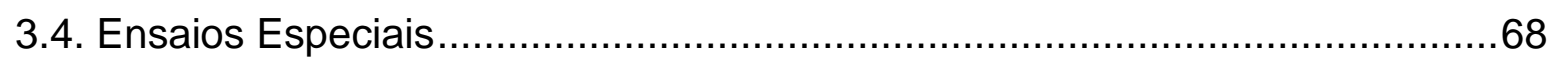

3.4.1. Descrição das prensas triaxiais utilizadas ..............................................68

3.4.2. Moldagem e compactação dos corpos de prova ....................................70 
3.4.3. Método de execução dos ensaios triaxiais convencionais....................... 70

3.4.5. Método de execução dos ensaios triaxiais multi-estágios ....................... 73

3.5. Análises em Microscópio Eletrônico de Varredura (MEV) ............................... 74

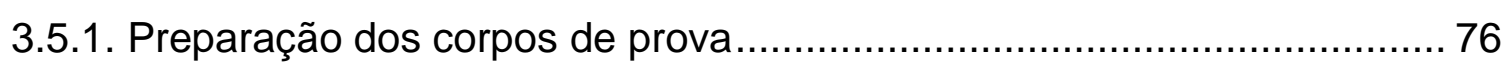

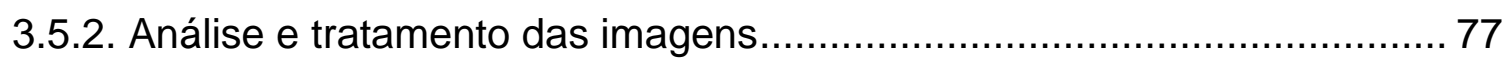

4. CARACTERIZAÇÃO GEOLÓGICO-GEOTÉCNICA DO SOLO UTILIZADO ........ 78

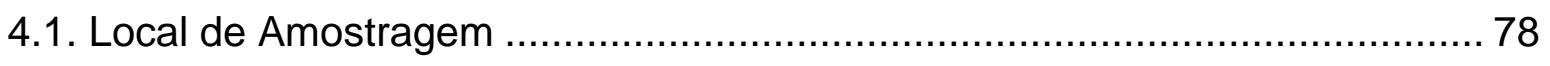

4.2. Caracterização Geológica Regional ....................................................... 79

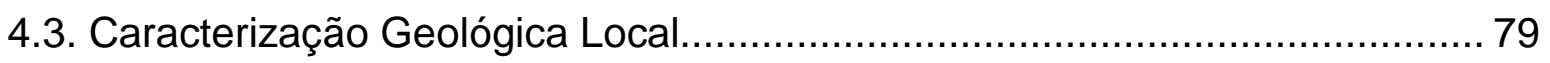

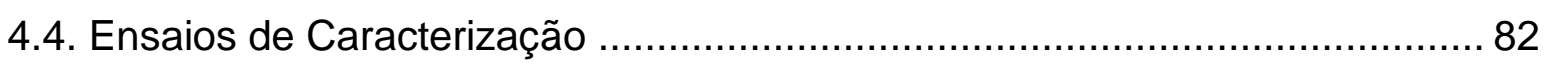

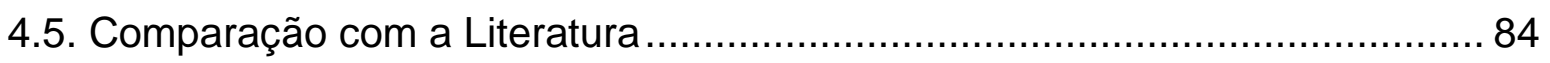

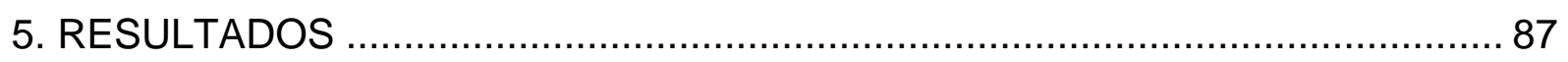

5.2. Ensaios Triaxiais do Tipo CIU em Amostras Compactadas ........................... 87

5.2.1. Ensaio convencional em amostra compactada (ensaio A: C-CIU-

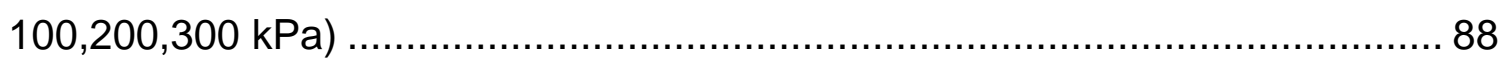

5.2.2. Ensaio multi-estágio em amostra compactada (ensaio B: ME-CIU-

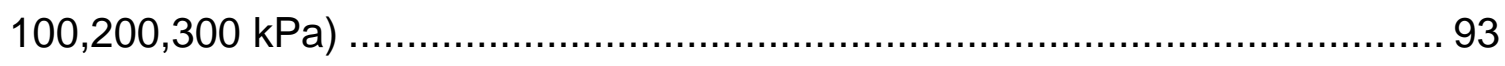

5.4. Ensaios Triaxiais em Amostras Indeformadas ………................................ 98

5.4.1. Ensaios triaxiais convencionais em amostras indeformadas ................... 98

5.4.2. Ensaios triaxiais multi-estágio em amostras indeformadas .................... 111

5.3. Ensaio de Cisalhamento Triaxial do Tipo ClU com Repetição da Tensão de Adensamento (ensaio C: ME-CIU-200,200,200 kPa).................................... 130

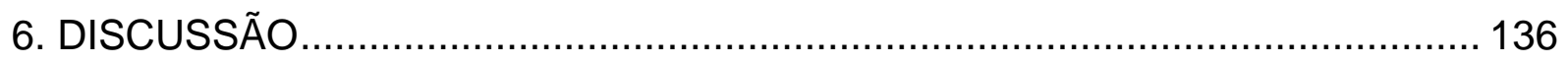

6.1. Avaliação de Ensaios Multi-Estágios em Amostras Compactadas................ 136

6.1.1. Comportamento tensão-deformação e desenvolvimento de poro-pressões 136

6.1.2. Trajetórias de tensão 139 
6.1.3. Parâmetros de resistência...............................................................140

6.1.4. Parâmetros de deformabilidade ......................................................142

6.2. Avaliação de ensaios multi-estágios em amostras indeformadas.................144

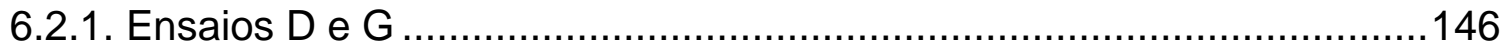

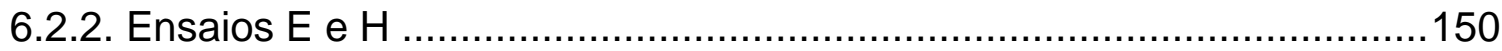

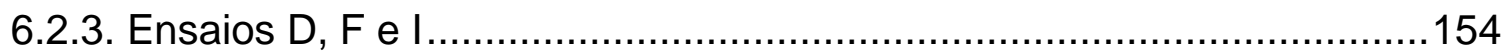

6.3. Efeito das etapas de cisalhamento intermediárias na estrutura dos corpos de

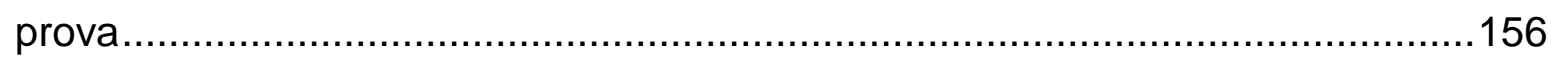

6.3.1. Avaliação do grau de perturbação do corpo de prova após as etapas de cisalhamento iniciais 157

6.3.2. Variação de volume e índice de vazios ao longo de ensaios multi-estágios 160

6.4. Análise microestrutural de corpos de provas submetidos à compressão triaxial 162

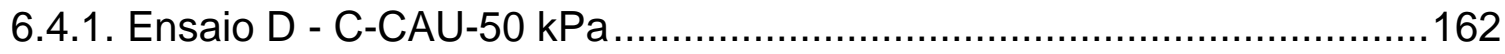

6.4.2. Ensaio D - C-CAU-100 kPa .......................................................165

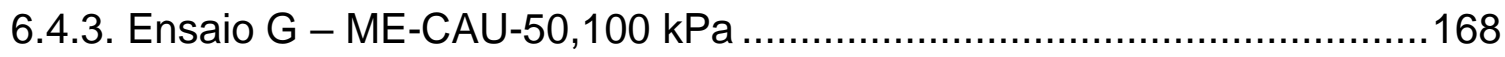

6.5. Influência da Heterogeneidade do Solo na Estimativa dos Parâmetros de Ruptura em Ensaios Convencionais ................................................................172

7. CONCLUSÃO

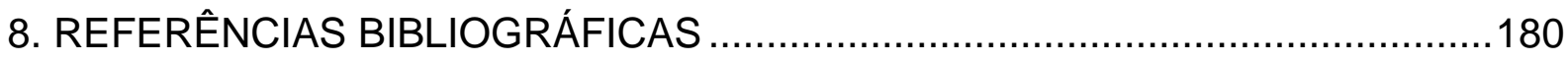

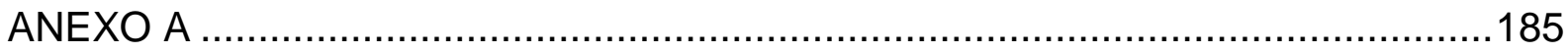




\section{LISTA DE FIGURAS}

Figura 1. Parâmetros de resistência e derivações no diagrama de Mohr (Head, 1998)

Figura 2. Esquema de uma câmara triaxial (modificado de Head, 1998) 36

Figura 3. Critérios utilizados para determinar a resistência de solos (adaptado de Head, 1998). 38

Figura 4. Processos mecânicos durante avanço do cisalhamento. Curva de tensãodeformação em tensão efetiva constante para argilas normalmente consolidadas (adaptado de Skempton, 1985) 40

Figura 5. (a) zona de cisalhamento de em um solo residual de argilito de Staffordshire (UK) visto em microscópio óptico (b) indicação das estruturas de cisalhamento (Kink Bands) (Tchalenko, 1967). 40

Figura 6. (a) relações texturais e estruturais de uma zona de cisalhamento em um solo residual de argilito de staffordshire (UK). $C=$ grumos de argila; $O=$ matéria orgânica; $\mathrm{S}$ = orientação de partículas (b) descontinuidades geradas por cisalhamento (Tchalenko, 1967) 41

Figura 7. Relações de zonas de cisalhamento de Riedel (PDS - Principal Displacement Shear) (Ahlgren, 2001). 42

Figura 8. Desenvolvimento de uma zona de cisalhamento (a) desenvolvimento inicial da zona de cisalhamento com formação da direção de cisalhamento menor R; (b) subsequente formação da zona conjugada R'; (c) Zonas $P$ são formadas com elevadas taxas de deformação; (d) formação do plano de ruptura (PDS - principal displacement shear) (Gyllland et al, 2013).

Figura 9. Critérios de paralisação de estágios intermediários utilizados em ensaios triaxiais multi-estágios. (a) paralisação em deformação definida previamente; (b) máxima tensão desviadora $\left(\mathrm{dq} / \mathrm{d} \varepsilon_{a}=0\right)$; (c) ponto onde a trajetória de tensões muda de direção e se estabiliza em uma tangente; (d) ponto crítico $\left(\varepsilon_{v}=0\right) ;(e) d \varepsilon_{v} / d q=0$ (adaptado de Sharma et al, 2011)

Figura 10: Esquema dos testes realizados por Kim e Ko. (a) estágios de cisalhamento consecutivos com pressão confinante constante; (b) teste realizado com primeiro e 
terceiro estágio de cisalhamento com a mesma tensão confinante e segundo estágio de cisalhamento executado com uma tensão confinante maior (adaptado de Kim e Ko, 1979)

Figura 11: Esquema do método de construção de envoltória de ruptura sugerido por Saeedy \& Mollah (1988). .52

Figura 12: Típica curva tensão-deformação de ensaios triaxiais multi-estágios não drenados, com indicação de restauração da deformação axial entre estágios de cisalhamento, devido retirada de carga axial (adaptado de Schoenemann e Pyles, 1988) 54

Figura 13. Diagramas tensão-deformação e trajetórias de tensões de ensaios triaxiais convencionais $(C)$ e multi-estátágios $(M)$. A série $A$ foi realizada em amostras compactadas e artificialmente sobreadensadas e a série $B$ foi realizada em amostras indeformadas (adaptado de Parry e Nadarajah, 1973) .55

Figura 14. Variações no índice de vazios (e) com incremento na tensão de adensamento em ensaios convencionais e multi-estágios. Em (A) resultados para argilas compactadas e sobreadensadas (série A) e em (B) amostras indeformadas (série B) (Parry e Nadarajah,1973).

Figura 15. (A) Diagramas de tensão-deformação e variação de volume em ensaios convencionais e multi-estágios drenados (B) Diagramas de tensão-deformação e variação de poro-pressões em ensaios convencionais e multi-estágios drenados (Saeedy e Mollah, 1988) .59

Figura 16. Curvas de tensão-deformação de um ensaio multi-estágio CIU em um solo residual de granito (adaptado de Ho e Fredlund, 1982) 60

Figura 17: Perfil de alteração (Vaz, 1996) 62

Figura 18. Coleta de bloco indeformado. (A) moldagem da amostra; (B) amostra moldada em formato cúbico; (C) amostra sendo coberta por papel laminado; e (D) amostra envolvida por papel laminado e tecido.

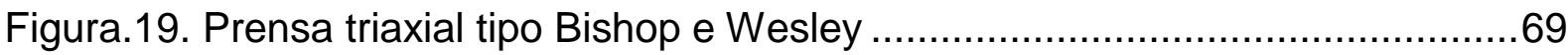

Figura 20. Prensa triaxial da Wykeham Farrance ................................................70 
Figura 21. Trajetória de tensões resultante do ensaio $F$, indicando as etapas de adensamento (linha tracejada em preto), de cisalhamento (curvas em preto), descarregamento axial (em vermelho) e dissipação das poro-pressões (em amarelo).

Figura 22. Trajetórias de tensões resultante do ensaio $G$, indicando ponto de finalização do ensaio e retirada da amostra para análises em MEV 75

Figura 23. Curvas de tensão-deformação do ensaio $\mathrm{G}$ e dos ensaios de 50 e $100 \mathrm{kPa}$ do ensaio $D$, indicando a máxima deformação a qual as amostras analisadas em MEV foram submetidas 76

Figura 24. Localização da área de estudo. (A) está indicado os limites da cidade universitária e em (B) há a demarcação do campo experimental (fonte: Google Earth ${ }^{\circledR}$, 2017) 78

Figura 25. Locais de retirada de blocos indeformados (blocos A, B e C) em talude préescavado no campo experimental de geotecnia do LMS-USP 80

Figura 26. Estruturas presentes no solo, observadas durante a moldagem de corpos de prova em amostra indeformada. (a) bolsões e bandamento herdados da rocha mãe; (b) bolsões quartzo-feldspáticos associados à veios de quartzo; (c) Fraturas preenchida por argilominerais e óxido e hidróxido de ferro; e em (d) núcleos de material poroso de coloração marrom ................................................................ 81

Figura 27. Mapeamento de detalhes em poços de inspeção (ABEF, 1989) ............. 82

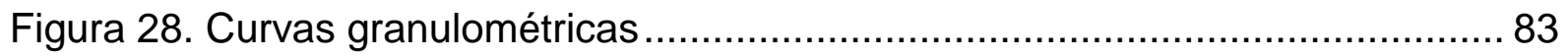

Figura 29. Classificação do solo na carta de plasticidade de Casagrande ................ 84

Figura 30. Carta de plasticidade de Casagrande com indicação dos dados obtidos na

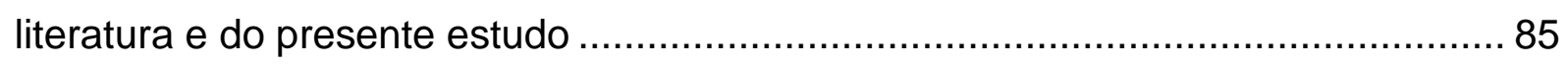

Figura 31. Curva de compactação obtida com energia normal............................... 87

Figura 32. Corpos de prova compactados após ensaio de cisalhamento triaxial (ensaio A)

Figura 33. Resultados do ensaio A - curvas de tensão-deformação e variação de poropressões versus deformação axial 89

Figura 34. Resultados do ensaio A - curvas de tensão-deformação normalizadas . 90 
Figura 35. Resultados do ensaio A - trajetórias de tensão

Figura 36. Resultados do ensaio A - Círculos de Mohr e envoltória de ruptura.........91

Figura 37. Resultados do ensaio A - Módulos de deformabilidade. .92

Figura 38. Resultados do ensaio A - Módulos de deformabilidade normalizados pela tensão efetiva média

Figura 39. Corpo de prova compactado após ruptura - ensaio B .93

Figura 40. Resultados do ensaio B - curvas de tensão-deformação e variação de pressão neutra

Figura 41. Resultados do e nsaio B - curvas de tensão-deformação normalizadas .95

Figura 42. Resultados do ensaio B - trajetórias de tensão .95

Figura 43. Resultados do ensaio B - círculos de Mohr e envoltória de ruptura ........96

Figura 44. Resultados do ensaio B - módulos de deformabilidade.

Figura 45. Resultados do ensaio B - módulos de deformação normalizado pela tensão confinante média

Figura 46. Resultados do ensaio D - corpos de prova ensaiados .99

Figura 47. Resultados do ensaio D - curvas de tensão-deformação e variação de poropressões versus deformação axial 100

Figura 48. (a) Curvas de tensão-deformação com comportamentos distintos: em A, ensaio realizado com tensão de adensamento abaixo da tensão de cedência; em $B$, ensaio com tensão confinante próximo a tensão de cedência; em $C$, ensaio com confinante maior que a tensão de cedência. $\mathrm{Em}$ (b) trajetórias de tensão e definição da curva de cedência (adaptado de Pinto, 2006) ..................................................102

Figura 49. Resultados do ensaio D- trajetórias de tensões .................................102

Figura 50. Resultados do ensaio D - círculos de Mohr e envoltória de ruptura interpretada 103

Figura 51. Resultados do ensaio D - módulos de deformação 104

Figura 52. Resultados do ensaio D - módulos de deformabilidade normalizados pela tensão efetiva média 104 
Figura 53. Resultados do ensaio E - corpos de prova cisalhados 105

Figura 54. Resultados do ensaio E - curva de tensão-deformação e variação de poropressão versus deformação axial

Figura 55. Resultados do ensaio E - curvas de tensão-deformação normalizados pela tensão confinante efetiva. 108

Figura 56. Resultados do ensaio $\mathrm{E}$ - trajetórias de tensões e envoltórias de ruptura interpretadas. 109

Figura 57. Resultados do ensaio E - círculos de Mohr e envoltória de ruptura interpretada. 109

Figura 58. Resultados do ensaio E - módulos de deformação 110

Figura 59. Resultados do ensaio E - módulos de deformação normalizados pela tensão efetiva média ( $\left.p^{\prime}\right)$.

Figura 60. Corpo de prova utilizado no ensaio $\mathrm{F}$ durante moldagem, ilustrando material poroso de coloração marrom escura no centro da amostra.

Figura 61. Corpo de prova utilizado no ensaio $F$ após ensaio de cisalhamento triaxial, com cavidades geradas pelo colapso dos bolsões porosos durante compressão.. 112 Figura 62. Resultados do ensaio $\mathrm{F}$ - gráficos de tensão-deformação e de variação de poro-pressões versus deformação axial 113

Figura 63. Resultados do ensaio F - gráfico de tensão-deformação normalizado pela tensão confinante efetiva 114

Figura 64. Resultados do ensaio F - diagrama de tensões com envoltória de ruptura interpretada. 114

Figura 65. Resultados do ensaio F - círculos de Mohr e envoltória de ruptura ...... 115

Figura 66. Resultados do ensaio F - módulos de deformação 115

Figura 67. Resultados do ensaio F - módulos de deformação normalizado pela tensão efetiva média ( $p$ ') 116

Figura 68. Resultados do ensaio $G$ - trajetórias de tensões indicando o ponto de paralisação do ensaio. 
Figura 69. Resultados do ensaio G - gráficos de tensão-deformação e de variação de poro-pressão versus deformação axial

Figura 70. Resultados do ensaio G - gráfico de tensão-deformação normalizado pela tensão confinante efetiva $\left(\sigma_{3}{ }^{\prime}\right)$.

Figura 71. Resultados do ensaio G - trajetórias de tensão

Figura 72. Resultados do ensaio G - círculos de Mohr e envoltória de ruptura ......120

Figura 73. Resultados do ensaio G - módulos de deformação secantes

Figura 74. Resultados do ensaio G - módulos de deformação normalizado pela tensão efetiva média ( $\left.p^{\prime}\right)$

Figura 75. Resultados do ensaio H - gráficos de tensão-deformação e de variação de poro-pressões versus deformação axial. 122

Figura 76. Resultados do ensaio $\mathrm{H}$ - gráfico tensão-deformação normalizado pela tensão confinante efetiva $\left(\sigma_{3}{ }^{\prime}\right)$ 123

Figura 77. Resultados do ensaio $\mathrm{H}$ - trajetórias de tensão 123

Figura 78. Resultados do ensaio $\mathrm{H}$ - círculos de Mohr e envoltória de ruptura ...... 124

Figura 79. Resultados do ensaio $\mathrm{H}-$ módulos de deformabilidade 124

Figura 80. Resultados do ensaio $\mathrm{H}$ - módulos de deformabilidade normalizados pela tensão efetiva média ( $p$ ') 125

Figura 81. Resultados do ensaio I - curva de tensão-deformação e variação de poropressão versus deformação axial. 126

Figura 82. Resultados do ensaio I - curvas de tensão deformação normalizadas pela tensão confinante efetiva 127

Figura 83. Resultados do ensaio I - trajetórias de tensões 128

Figura 84. Resultados do ensaio I - círculos de Mohr e envoltória de ruptura..... 128

Figura 85. Resultados do ensaio I - módulos de deformabilidade secantes. 129

Figura 86. Resultados do ensaio I - módulos de deformabilidade normalizados por p' 
Figura 87. Resultados do ensaio C - curvas de tensão-deformação e variação de poropressões versus deformação axial 131

Figura 88. Resultados do ensaio $\mathrm{C}$ - trajetória de tensões efetivas 132

Figura 89. Resultados do ensaio C - Trajetória de tensões totais. 133

Figura 90. Resultados do ensaio C - círculo de Mohr obtidos. 133

Figura 91. Resultado s do ensaio C - módulos de deformação 134

Figura 92. Resultados do ensaio $C$ - módulos de deformação normalizado pela tensão efetiva média ( $\left.p^{\prime}\right)$. 134

Figura 93. Comparação entre o comportamento de tensão-deformação e de variação de poro-pressões resultantes dos ensaios $A$ e $B$. 137

Figura 94. Comparação das trajetórias de tensões obtidas nos ensaios A e B ...... 140

Figura 95. Círculos de Mohr obtidos nos ensaios A e B 141

Figura 96. Comparação entre módulos de deformabilidade secantes obtidos nos ensaios A e B. 143

Figura 97. Módulos de deformabilidade secantes normalizados por p' obtidos nos ensaios $A$ e $B$ 143

Figura 98. Comparativo das trajetórias de tensões obtidas nos ensaios D, F, G, H e I 145

Figura 99. Gráficos de tensão-deformação e variação de poro-pressões dos ensaios G e D 146

Figura 100. Trajetórias de tensões resultantes dos ensaios D e G 147

Figura 101. Módulos de deformabilidade obtidos no ensaio G e D 148

Figura 102. Módulos de deformabilidade normalizados por p' obtidos nos ensaios D e G. 149

Figura 103. Curvas de tensão-deformação dos ensaios D e G 150

Figura 104. Curvas de tensão-deformação e variação de poro-pressões dos ensaios E e H. 151

Figura 105. Trajetórias de tensões obtidas nos ensaios E e H 152 
Figura 106. Círculos de Mohr de ruptura obtidos nos ensaios E e H 152

Figura 107. Módulos de deformabilidade secantes obtidos nos ensaios E e H.......153

Figura 108. Comparativo dos módulos de deformabilidade secantes obtidos nos ensaios $\mathrm{E}$ e $\mathrm{H}$.

Figura 109. Curvas de tensão-deformação e curvas de variação de variação de poropressões versus deformação axial obtidas nos ensaios $\mathrm{D}, \mathrm{F}$ e I 155

Figura 110. Trajetórias de tensões e envoltórias de ruptura obtidas nos ensaios $D, F$ el 156

Figura 111. Trajetórias de tensão do ensaio C, indicando deslocamento das trajetórias de tensão para a direita ao longo do ensaio 158

Figura 112. (A) módulos de deformabilidade secantes obtidos no ensaio C. (B) módulos de deformabilidade secantes normalizados por p' 159

Figura 113. Variação do índice de vazios durante os estágios de adensamento dos ensaios D e G. (A) gráfico entre razão do índice de vazios ao longo do adensamento e o índice de vazioinicial versus aumento da tensão confinante. (B) gráfico da variação do índice de vazios versus aumento da tensão confinante 161

Figura 114. Trecho do plano de ruptura obtido no ensaio D-C-CAU-50 kPa observado em MEV. 163

Figura 115. Detalhe do plano de ruptura obtido no ensaio D-C-CAU-50 kPa, ilustrando as paredes e o seu preenchimento, com indicação dos pontos observados com maior detalhe. (1) textura de um grumo de solo; (2) textura do preenchimento da falha, ao lado do grumo; (3) textura do solo próximo à parede do plano de ruptura 164

Figura 116. Trecho do plano de ruptura obtido no ensaio D-C-CAU-50 kPa, com lineações próximas às paredes de falha evidentes (kink bands). 165

Figura 117. Trecho do plano de ruptura obtido no ensaio D-C-CAU-100 kPa observado em MEV. 166

Figura 118. Zona de cisalhamento do ensaio D-C-CAU-100 kPa, com indicações do esquema de Riedel, com indicador cinemático provando caráter antitético de R'...167 
Figura 119. Zona de cisalhamento do ensaio D-C-CAU-100 kPa. (A) detalhe do PSZ com preenchimento; $(B)$ imagem de maior detalhe diferenciando a textura interna e externa do PSZ.

Figura 120. Trecho do plano de ruptura obtido no ensaio D-C-CAU-100 kPa observado em MEV 169

Figura 121. Microestruturas observadas na zona de cisalhamento gerada no ensaio G-ME-CAU-50,100 kPa. Em 1, 1A e 1B observa-se aglomerado mineral que preenche o plano de ruptura: em 2 e $2 A$ há um detalhe do preenchimento do plano; e em 3 e 3A observa-se lineações geradas próximas ao plano de falha. 170

Figura 122. Detalhe das paredes do plano de ruptura gerada no ensaio G-ME-CAU$50,100 \mathrm{kPa}$ 171

Figura 123. Comportamento tensão-deformação obtidos nos ensaios D e E. 173

Figura 124. Trajetórias de tensões obtidas nos ensaios D e E 174

Figura 125. Dificuldades de interpretação de ensaios convencionais devido a elevada heterogeneidade do solo apresentadas no ensaio $D$ 175

Figura 126. Círculos de Mohr de ruptura obtidos por ABEF (1989). Em (A) e (B) resultados de ensaios UU; Em (C) resultados de um ensaio CD: e em (D) resultados de um ensaio CU (adaptado de ABEF, 1989). 176 


\section{LISTA DE TABELAS}

Tabela 1. Critérios de paralisação já utilizados em ensaios multi-estágios

Tabela 2. : Comparação de fatores que afetam a resistência de solos de alteração e transportados (adaptado de Brenner et al, 1997)

Tabela 3. Programa experimental - ensaios especiais realizados 65

Tabela 4. Frações granulométricas presentes nos blocos A, B e C .83

Tabela 5. Ensaios de caracterização - comparativo com os dados da literatura (frações granulométricas, limites de Atterberg e densidade dos grãos). .85

Tabela 6. Parâmetros de resistência do solo em estudo .86

Tabela 7 . Características dos corpos de prova compactados utilizados nos ensaios $A$ e B .88

Tabela 8. Resultados do ensaio D - características iniciais dos corpos de prova ....98

Tabela 9. Resultados do ensaio E - características iniciais dos corpos de prova ensaiados 105

Tabela 10. Resultados do ensaio F - características iniciais do corpo de prova utilizado

Tabela 11. Resultados do ensaio $\mathrm{G}$ - características iniciais e corpo de prova após cisalhamento

Tabela 12. Resultados do ensaio $\mathrm{H}$ - características iniciais do corpo de prova e imagem do corpo de prova cisalhado.

Tabela 13. Resultados do ensaio I - características iniciais e imagem do corpo de prova cisalhado 125

Tabela 14. Resultados do ensaio C - características iniciais do corpo de prova ensaiado.

Tabela 15. Parâmetros de resistência e síntese das condições do ensaio nos pontos de ruptura.

Tabela 16. Parâmetros de resistência do solo compactado: comparativo com a literatura 
Tabela 17. Síntese dos parâmetros de resistência obtidos em amostras indeformadas 145

Tabela 18. Dados dos ensaios D e G na ruptura ............................................. 147

Tabela 19. Pontos de ruptura inferidos nos três estágios do ensaio $C$................... 157

Tabela 20. Parâmetros de resistência efetivos do solo........................................ 174 


\section{LISTA SÍMBOLOS E ABREVIAÇÕES}

$\mathrm{C}=$ Ensaios triaxiais convencionais

$\mathrm{ME}=$ Ensaios triaxiais multi-estágios

$\mathrm{CAU}=$ Ensaio triaxial adensado anisotrópico não drenado

$\mathrm{CIU}=$ Ensaio triaxial adensado isotrópico drenado

$C A D=$ Ensaio triaxial adensado anisotrópico drenado

$\mathrm{CID}=$ Ensaio triaxial adensado isotrópico drenado

UU = Ensaio triaxial não adensado não drenado

$\mathrm{cp}=$ Corpo de prova

$\mathrm{w}=$ Umidade $[\%]$

$\mathrm{W}_{\mathrm{ot}}=$ Umidade ótima [\%]

$Y_{d}=$ Densidade seca $\left[\mathrm{g} / \mathrm{cm}^{3}\right]$

e = Índice de vazios

$\mathrm{S}=$ Grau de saturação [\%]

IP = Índice de plasticidade $=$ LL - LP [\%]

$\mathrm{LL}=$ Limite de liquidez [\%]

LP $=$ Limite de plasticidade [\%]

$\mathrm{CL}=$ Argila de baixa plasticidade

$\mathrm{CH}=$ Argila de alta plasticidade

$\mathrm{ML}=$ Silte de baixa plasticidade

$\mathrm{MH}=$ Silte de baixa plasticidade

B = Parâmetro B de Skempton

$\delta=$ Tensão cisalhante $[\mathrm{kPa}]$

$\sigma_{1}=$ sig1 $=$ Tensão principal maior $=$ tensão axial total $[\mathrm{kPa}]$

$\sigma_{3}=$ sig3 $=$ Tensão principal menor $=$ tensão confinante total $[\mathrm{kPa}]$

$\sigma=$ Tensão normal total $[\mathrm{kPa}]$ 
$\sigma^{\prime}=$ Tensão normal efetiva $[\mathrm{kPa}]$

$\sigma_{1}{ }^{\prime}=\operatorname{sig}_{1}{ }^{\prime}=\sigma_{1}-\mathrm{u}=$ Tensão axial efetiva $[\mathrm{kPa}]$

$\sigma_{3}{ }^{\prime}=\operatorname{sig}_{3}{ }^{\prime}=\sigma_{3}-\mathrm{u}=$ Tensão confinante efetiva $[\mathrm{kPa}]$

$\mathrm{u}=$ Poro pressão $[\mathrm{kPa}]$

$\Delta \mathrm{u}=$ Variação de poro pressão $[\mathrm{kPa}]$

$\Delta v=$ Variação volumétrica $\left[\mathrm{cm}^{3}\right]$

$q=$ Tensão desviadora $=\sigma_{1}^{\prime}-\sigma_{3}^{\prime}[\mathrm{kPa}]$

$\varepsilon_{a}=$ Deformação axial [\%]

$\varepsilon_{v}=$ Deformação volumétrica [\%]

$\mathrm{t}=\left(\sigma_{1}-\sigma_{3}\right) / 2[\mathrm{kPa}]$

$s=\left(\sigma_{1}+\sigma_{3}\right) / 2[\mathrm{kPa}]$

$s^{\prime}=\left(\sigma_{1}{ }^{\prime}+\sigma_{3}{ }^{\prime}\right) / 2[\mathrm{kPa}]$

$p^{\prime}=$ Tensão efetiva média $=\left(\sigma_{1}+2 \sigma_{3}\right) / 3[\mathrm{kPa}]$

$\mathrm{E}=$ Módulo de deformabilidade de Young $[\mathrm{kPa} / \mathrm{MPa}]$

$\mathrm{c}=$ Coesão $[\mathrm{kPa}]$

$c^{\prime}=$ Coesão efetiva $[\mathrm{kPa}]$

$\varphi=$ Ângulo de atrito $\left[{ }^{\circ}\right]$

$\varphi^{\prime}=$ Ângulo de atrito efetivo $\left[^{\circ}\right]$

IP = Índice de plasticidade = LL - LP [\%]

$\mathrm{LL}=$ Limite de liquidez [\%]

LP = Limite de plasticidade [\%]

$\mathrm{CL}=$ Argila de baixa plasticidade

$\mathrm{CH}=$ Argila de alta plasticidade

$\mathrm{ML}=$ Silte de baixa plasticidade

$\mathrm{MH}=$ Silte de baixa plasticidade 


\section{INTRODUÇÃO}

Em geral, os solos residuais são caracterizados por apresentar elevada heterogeneidade, herdada da rocha-mãe. Por isso, a determinação dos parâmetros de resistência destes solos em laboratório é dificultada, pois a obtenção de amostras replicáveis e de boa qualidade é difícil e, em alguns casos, de alto custo. Para minimizar o efeito da variabilidade do solo, a técnica multi-estágio é uma ferramenta que pode contribuir para a definição de parâmetros representativos.

Os ensaios triaxiais multi-estágios permitem a determinação dos parâmetros de resistência utilizando apenas uma amostra. Um único corpo de prova é submetido a três estágios de cisalhamento, com diferentes pressões confinantes, permitindo a construção da envoltória de ruptura. Desta forma, não é necessário a interpolação de dados obtidos de amostras distintas, como realizado no método tradicional. Além disso, a técnica multi-estágios reduz o número de amostras e o tempo de ensaio, podendo ser uma ferramenta interessante na otimização de projetos geotécnicos.

A técnica multi-estágio é utilizada desde a década 1950 (e. g. Taylor, 1950) e com o desenvolvimento dos equipamentos de ensaios triaxiais este procedimento se tornou relativamente simples. Porém, a utilização deste tipo de ensaio ainda é restrita, devido à falta de normatização e de dificuldades de execução.

As principais dificuldades de execução de ensaios multi-estágios é a definição do critério de paralisação e a construção da envoltória de ruptura, sem a mobilização total dos parâmetros de resistência. Há na literatura diversas sugestões de metodologias de execução de ensaios multi-estágios, para diferentes tipos de ensaio e tipo de solo, que serão descritas no capítulo 2.

Em solos residuais, Ho e Fredlund (1982), Rahardjo et al (1995) e Khosravi et al (2011) testaram a técnica multi-estágios em solos residuais e obtiveram parâmetros de resistência correlatos com os obtidos em ensaios convencionais. Porém, alguns autores não indicam a aplicação desta técnica em solos residuais. Alguns autores sugerem que os estágios subsequentes de cisalhamento podem gerar deformações acumuladas e perturbações na estrutura do corpo de prova, resultando em quebra das ligações por cimentação, realinhamento dos grãos de argila e mudanças nos índices de vazios. 
Tendo em vista estas dificuldades e considerando o potencial prático e econômico da técnica multi-estágio, a presente pesquisa tem o objetivo de avaliar a viabilidade da aplicação desta técnica em solos residuais saturados para a determinação de parâmetros de resistência e módulos de deformabilidade.

Para tanto, foram realizados ensaios triaxiais convencionais e ensaios multi-estágios em um solo residual jovem migmatítico, retirado do campus Butantã da Universidade de São Paulo, na zona oeste do município de São Paulo, Brasil. Foram realizados ensaios em amostras indeformadas e compactadas e os parâmetros de resistência e deformabilidade obtidos em cada tipo de ensaio foram comparados, com o objetivo de avaliar os resultados obtidos em ensaios triaxiais múltiplos.

O efeito dos estágios sucessivos de cisalhamento na estrutura do solo foi avaliado em análises em microscópio eletrônico de varredura, na tentativa de avaliar as perturbações na estrutura do solo após a execução dos estágios intermediários.

\subsection{Justificativa}

O uso da técnica multi-estágios em ensaios triaxiais para solos residuais ainda exige estudos que estabeleçam os procedimentos mais adequados para a acurada determinação dos parâmetros de ruptura. No Brasil, estudos deste tipo são restritos. A validação e a difusão desta técnica para este tipo de solo deverão proporcionar uma redução no tempo de ensaios e na quantidade de amostras, sendo eficaz na otimização de projetos geotécnicos .

\subsection{Objetivos}

Os objetivos do presente projeto são:

- Verificar a validade da técnica multi-estágio para obtenção de parâmetros de resistência e deformabilidade para um solo residual em amostras indeformadas e compactadas.

- Avaliar os efeitos da execução de estágios sucessivos de cisalhamento na estrutura do solo, por meio de análise de microscopia eletrônica. 


\subsection{Organização da dissertação}

A presente dissertação foi organizada em 7 capítulos, sendo eles: introdução; revisão bibliográfica; métodos; caracterização do solo utilizado; resultados; discussão; e conclusões, em ordem numérica.

No capítulo 2 é apresentada uma revisão sobre a resistência ao cisalhamento de solos, incluindo os aspectos teóricos utilizados na determinação das condições de ruptura e os mecanismos de ruptura a partir de um carregamento axial. Em seguida, são apresentadas as diversas propostas metodológicas para a execução de ensaios triaxiais multi-estágios e a influência da utilização desta técnica na definição dos parâmetros de resistência para determinados tipos de solo. Por fim, apresenta-se as principais características dos solos residuais e os fatores que influenciam na resistência deste tipo de solo.

O capítulo 3 apresenta o plano experimental e as metodologias adotadas em cada uma de suas etapas.

No capítulo 4 é apresentada a caracterização geológico-geotécnica do solo utilizado, com apresentação da geologia regional, observações em campo, resultados de ensaios laboratoriais e comparação com dados da literatura. Parte deste estudo resultou na publicação "Caracterização geológico-geotécnica do solo residual proveniente gnaisses migmatíticos do Complexo Embu, São Paulo, SP" (Lemos e Marinho, 2018), sendo a principal fonte citada neste capítulo.

O capítulo 5 traz os resultados obtidos nos ensaios triaxiais convencionais e multiestágios, apresentando os parâmetros de resistência e deformabilidade obtidos e a interpretação do comportamento tensão-deformação deste solo em cada um dos ensaios realizados.

No capítulo 6 é apresentada a avaliação dos resultados obtidos utilizando a técnica multi-estágio nas amostras compactadas e indeformadas, realizada a partir da comparação com os resultados obtidos em ensaios convencionais. Também são discutidos os efeitos das etapas de cisalhamento sucessivas na estrutura do solo, a partir de análises que integram imagens em microscópio eletrônico, resultados dos ensaios e dados da literatura.

Por fim, o capítulo 7 apresenta as conclusões obtidas neste estudo e sugestões para estudos futuros. 


\section{REVISÃO BIBLIOGRÁFICA}

Este capítulo apresenta os principais aspectos teóricos utilizados como base para a determinação da metodologia utilizada no programa experimental e para a interpretação e compreensão dos resultados obtidos. É apresentada uma revisão sobre resistência ao cisalhamento dos solos, incluindo os mecanismos de ruptura a partir de análises em microescala e os aspectos teóricos utilizados na determinação das condições de ruptura. Em seguida, apresentam-se os principais aspectos metodológicos de ensaios triaxiais multi-estágios e a influência desta metodologia na determinação dos parâmetros de resistência. Por fim, apresenta-se as principais características dos solos residuais e os fatores que influenciam na resistência deste tipo de solo.

\subsection{Resistência ao Cisalhamento de Solos}

A resistência ao cisalhamento de um solo pode ser definida como a máxima tensão que o solo pode suportar sem que ocorra ruptura ou como a tensão de cisalhamento do solo no plano onde ocorre a ruptura (e.g. Pinto, 2006).

De acordo com Head (1998), a resistência do solo é influenciada pelas seguintes características naturais do solo: mineralogia, distribuição granulométrica, formato dos grãos, índice de vazios, presença de água, estrutura, histórico de tensões préexistentes e existência de tensões in situ. De acordo com o autor, para a determinação dos parâmetros de resistência é necessário relacionar a tensão de cisalhamento (ס) e a tensão normal $(\sigma)$ na superfície de ruptura. A relação das tensões de ruptura com os parâmetros de resistência pode ser obtida pela envoltória de Mohr-Coulomb, definida pela equação 1 .

$$
\delta=c+\sigma \cdot \tan ^{\prime} \varphi \quad \text { (equação 1) }
$$

Onde c e $\varphi$ são constantes que representam a coesão e o ângulo de atrito do solo, respectivamente.

Para determinação dos parâmetros de resistência efetivos, considera-se a ação da poro-pressão, como indicado na equação 2 , onde $u$ representa a pressão de neutra.

$$
\delta^{\prime}=c^{\prime}+(\sigma-u) \cdot \tan \varphi^{\prime} \quad \text { (equação 2) }
$$

Os parâmetros de resistência totais ou efetivos podem ser obtidos a partir da ensaios de compressão triaxiais, plotando os círculos de Mohr de ruptura e traçando a 
envoltória tangente aos círculos (e.g. Head, 1998). O ângulo de atrito é o ângulo entre a envoltória de ruptura e o eixo horizontal. A coesão é dada pelo intercepto da envoltória de ruptura no eixo vertical, como ilustrado na Figura 1.

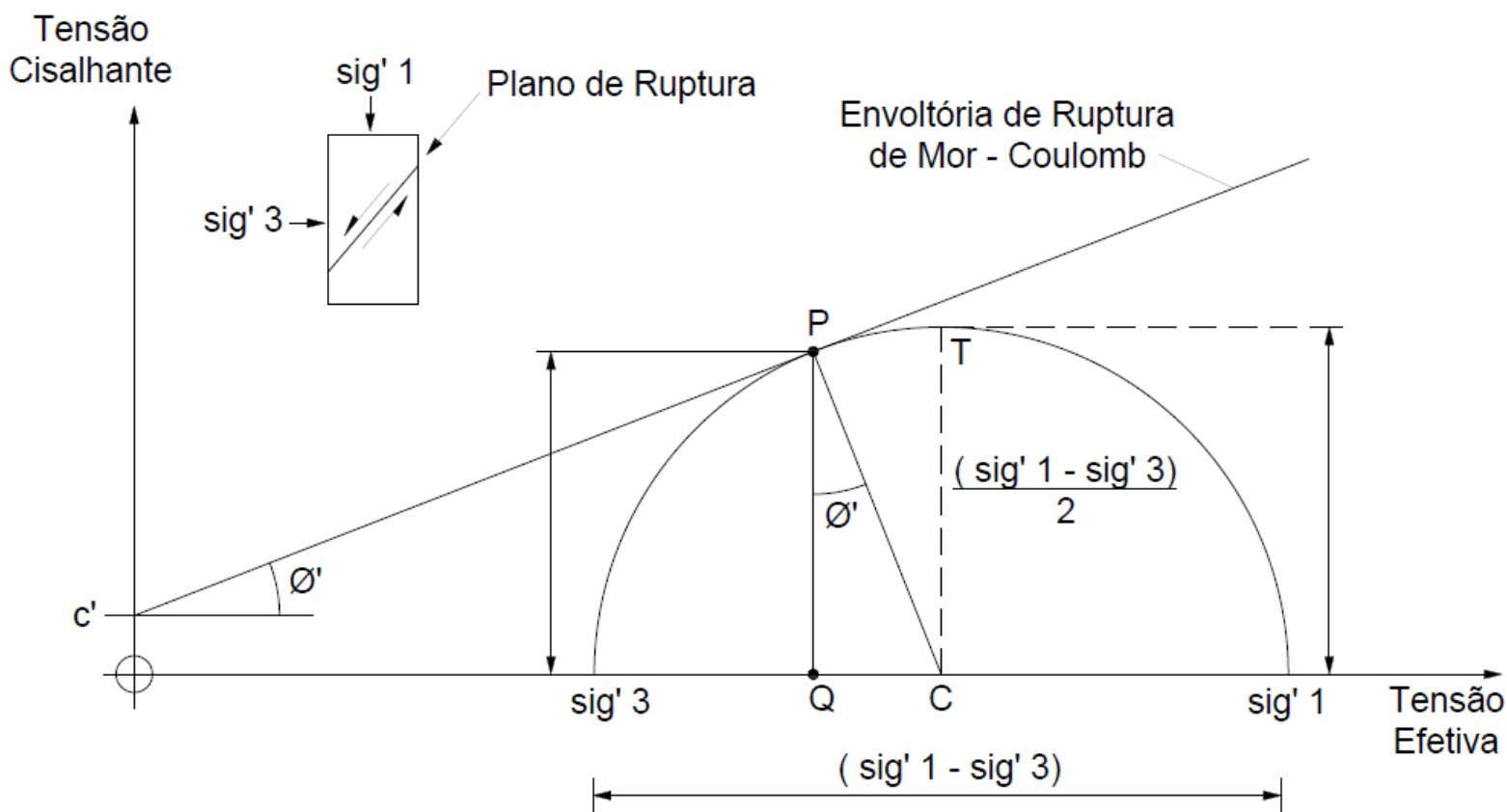

Figura 1. Parâmetros de resistência e derivações no diagrama de Mohr (Head, 1998)

\subsubsection{Ensaios de compressão triaxiais convencional}

Segundo Pinto (2006), o ensaio de compressão triaxial é realizado a partir da aplicação de um estado hidrostático de tensões e de um carregamento vertical em uma amostra de formato cilíndrico. Para isto, o corpo de prova é colocado em uma câmara triaxial (Figura 2) e, em seguida, é envolvido em uma membrana impermeável. Após, a câmara é preenchida por água, onde aplica-se a tensão confinante, que atua em todas as direções, denominada de tensão confinante.

O cisalhamento é induzido por meio da aplicação de uma carga axial. A carga axial, aplicada pelo deslocamento de um pistão, é medida por uma célula de carga ou um anel dinamométrico. Durante este carregamento, a deformação axial provocada no corpo de prova é medida por um sensor de deslocamento, permitindo, assim, a obtenção das relações de tensão-deformação.

O carregamento axial permite o traçado dos círculos de Mohr correspondentes. A determinação dos parâmetros de resistência é realizada pelo traçado da envoltória de 
ruptura, tangente aos círculos de Mohr de ruptura obtidos em, no mínimo, três ensaios triaxiais realizados com tensões de adensamento diferentes.

Em ensaios realizados na condição não drenada, a variação de poro-pressões durante o carregamento também é monitorada, permitindo a obtenção dos parâmetros de resistência efetivos. Em relação às condições de drenagem, há três tipos de ensaios triaxiais: CD, CU e UU. O ensaio CD é realizado permitindo a drenagem de água nas fases de adensamento e de cisalhamento. O ensaio CU permite drenagem de água apenas na fase de adensamento, desta forma, não ocorre variação de volume do corpo de prova durante o carregamento axial. No ensaio UU a drenagem não é permitida nas fases de adensamento e cisalhamento.

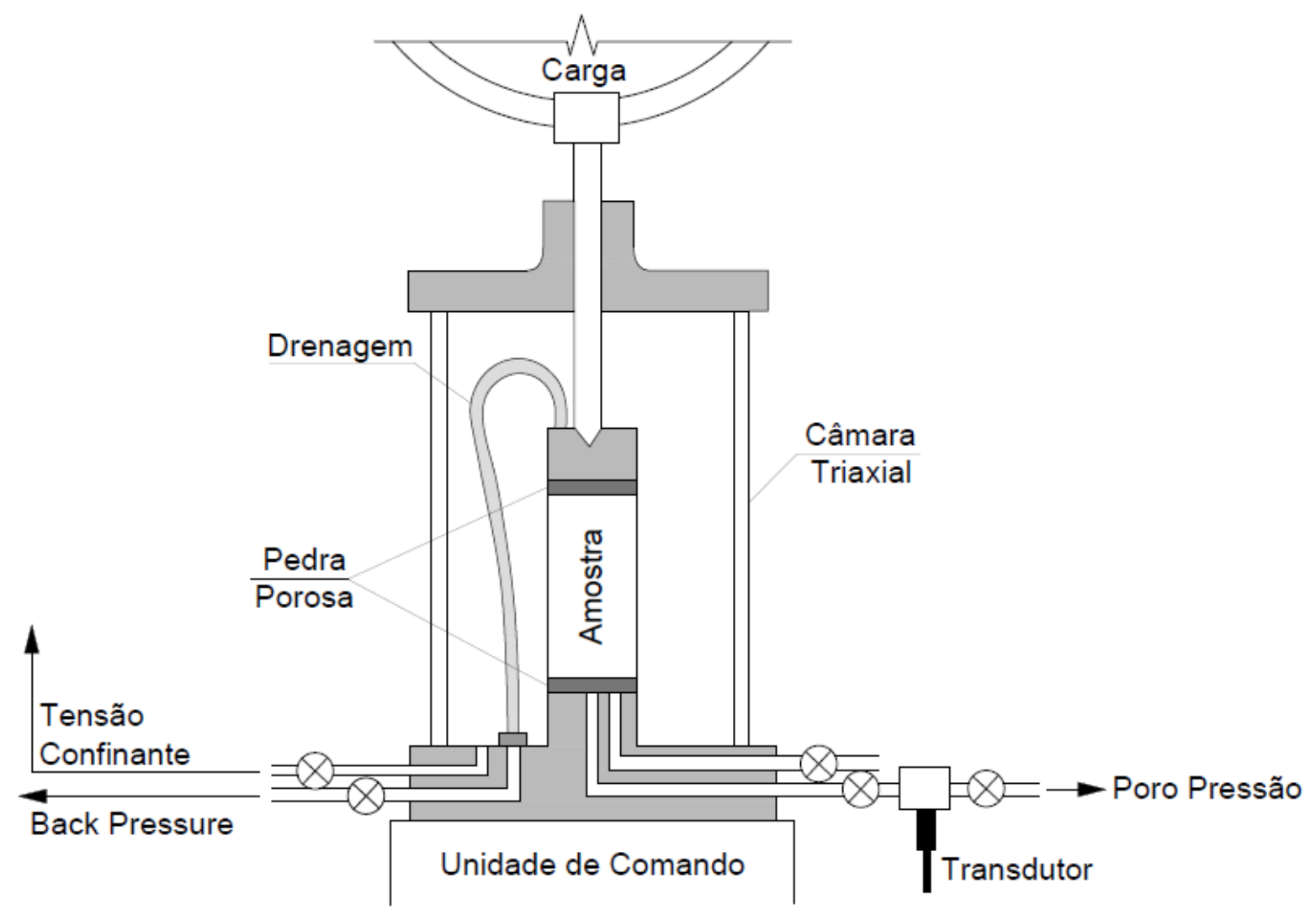

Figura 2. Esquema de uma câmara triaxial (modificado de Head, 1998)

\subsubsection{Critérios para determinação da resistência ao cisalhamento em ensaios} triaxiais

De acordo com Head (1998), há cinco critérios para determinar a resistência ao cisalhamento em ensaios triaxiais, que são os seguintes:

a) pico da tensão desviadora: $\left(\sigma_{1}-\sigma_{3}\right)_{\max }$;

b) máxima razão de tensões principais: $\left(\sigma_{1} / \sigma_{3}\right)_{\max }$; 
C) deformação limitante: $\varepsilon$ lim;

d) estado crítico; e

e) Resistência residual

A adoção de um destes critério depende do tipo de solo em estudo e do objetivo da análise. A Figura 3 ilustra estes critérios em diagramas de tensão-deformação e de variação de volume.

O critério (a) considera a ocorrência da ruptura no pico da tensão desviadora. Este critério é o mais tradicional e é utilizado em diversos tipos de solos.

Kenney e Watson (1961) não indicam a utilização do critério (a) para ensaios não drenados. Para ensaios não drenados, o critério (b) é mais indicado, pois traz uma melhor correlação da resistência ao cisalhamento com outros parâmetros do solo, além de evidenciar de forma mais efetiva o pico de tensões, principalmente em solos cuja tensão desviatória é continuamente crescente até elevadas deformações. Kenney e Watson (1961), porém, alertam que este critério não representa o exato momento da ruptura em ensaios não drenados realizados em argilas sobreadensadas.

O critério (c) pode ser utilizados em solos cujos picos de resistência ocorrem em deformações muito elevadas e, por isso, definir um limite de deformação pode ser mais apropriado, devido a limitações laboratoriais. Neste caso, a escolha do limite da deformação alcançada pelo ensaio ( $\varepsilon_{\lim }$ ) deve levar em conta as solicitações da obra a qual os dados dos ensaios serão aplicados. Este critério também é comumente aplicado em ensaios multi-estágios (Head, 1998).

O critério (d) considera que a resistência de um solo é definida em seu ponto crítico. Este critério é indicado para ensaios drenados realizados em areias fofas e compactas. De acordo com Head (1998), o estado crítico é uma característica intrínseca do material e sua definição depende apenas das tensões efetivas. Em contraponto, o pico de tensão desviadora depende do índice de vazios e da densidade inicial da amostra, que pode ser muito variável e não replicável em laboratório. Por isso, a adoção deste critério de ruptura é mais adequada para materiais arenosos.

Segundo Head (1998), o critério (e) pode ser aplicado à solos que já foram submetidos a tensões cisalhantes e, que após deslocamento no plano de ruptura, apresentam estabilização da resistência. 


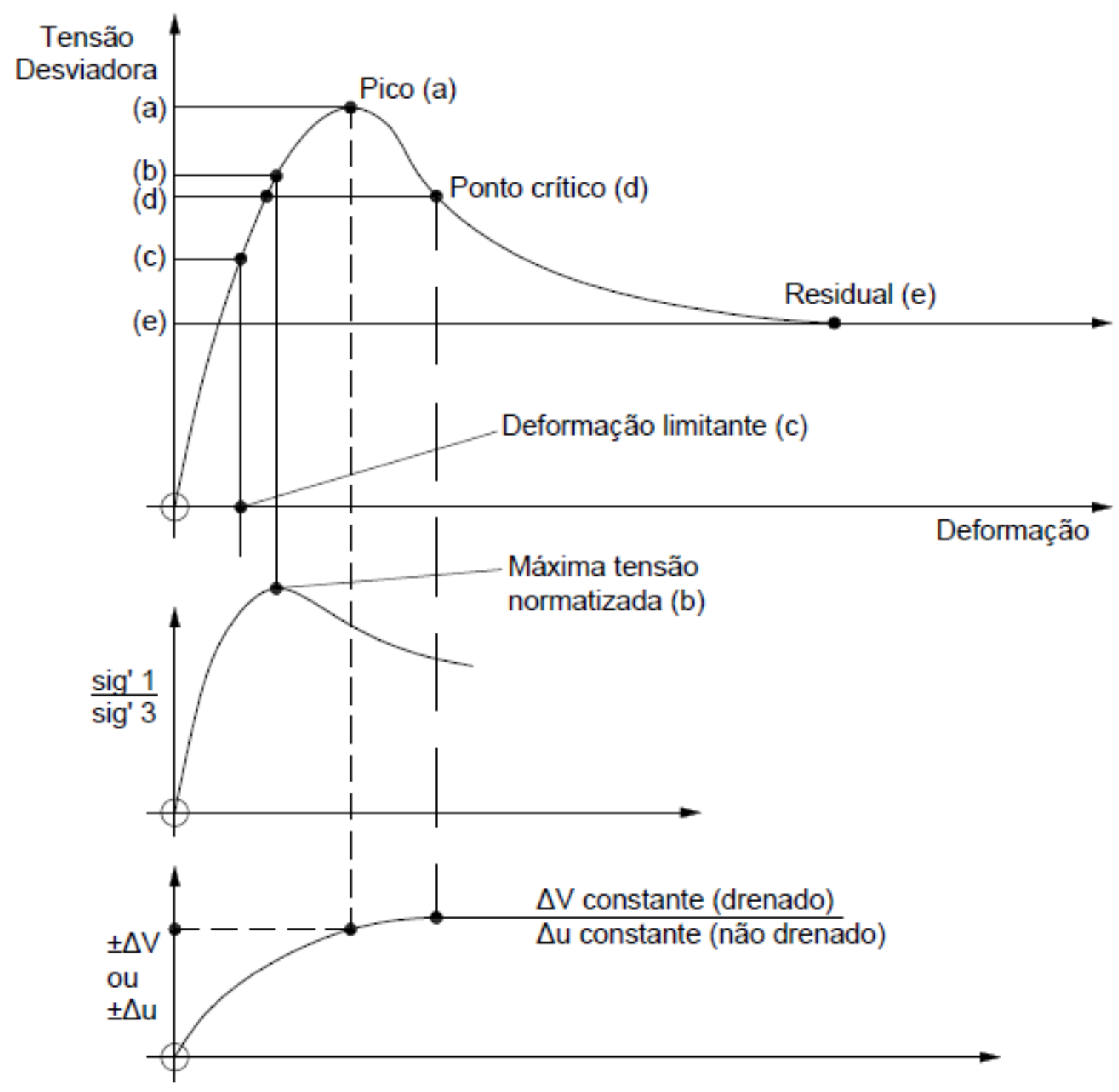

Figura 3. Critérios utilizados para determinar a resistência de solos (adaptado de Head, 1998)

\subsection{Zonas de Cisalhamento e Mecanismos de Ruptura em Solos}

Fossen (2012) define uma zona de cisalhamento como uma zona de formato tabular onde a deformação é substancialmente maior do que no material ao seu redor, contendo pelo menos um componente de cisalhamento simples.

Em rochas, zonas de cisalhamento são geradas por esforços tectônicos e podem ocorrer tanto em microescala como possuir quilômetros de extensão. Em regime rúptil, ocorrente em baixas temperaturas e pressões na crosta superior, as zonas de cisalhamento em rochas são marcadas por fraturas e falhas. Em níveis crustais profundos a deformação plástica é dominante, e por isso, em grandes profundidades há formação de zonas de cisalhamento dúcteis, onde observa-se rotação e recristalização de grãos, realinhamento da foliação e propagação de dobras. 
Em solos, as zonas de cisalhamento podem ser geradas por fenômenos naturais ou antrópicos, como quando ocorre um escorregamento de uma encosta ou quando uma sapata de fundação é carregada, por exemplo (Pinto, 2006). As zonas de cisalhamento ocorrem em baixos níveis de tensões, quando comparados às ocorrentes e rochas, e, por isso, são pouco desenvolvidas, apresentando espessuras micrométricas a centimétricas. Devido a escala de trabalho, muitas vezes apenas o plano de ruptura é considerado.

As tensões de cisalhamento modificam a estrutura do solo original por rearranjo das partículas, cominuição de agregados de argila e redistribuição de poros. De acordo com Wen e Aydin (2002), no processo de cisalhamento de cisalhamento em solos ocorrem três processos mecânicos: compactação, cominuição de agregados minerais (grumos) e rearranjo de partículas. Estes processos ocorrem em estágios distintos durante o processo de deformação, como previsto pelo modelo teórico de Skempton (1985), como ilustrado na Figura 4. Segundo os autores, a mobilização da resistência inicia-se com a compactação da zona de cisalhamento, seguido pelo processo de cominuição de grumos e agregados e continuado pelo rearranjo de partículas, seguido, por fim, pela movimentação do plano.

Em um solo saturado, a fase de compactação ocorre com a expulsão da água dos poros, em condições drenadas. Esta fase causa o enrijecimento da zona de cisalhamento. $\mathrm{Na}$ fase seguinte, o aumento da tensão pode resultar na delaminação de placas de argila e quebra da cimentação que une os grãos de um grumo. Os agregados de argila podem ser delaminadas em fibras, placas individuais ou em agregados menores. Esta fase resulta na diminuição dos poros e densificação do solo. A fragmentação dos agregados reduz a resistência ao cisalhamento do solo. Na fase seguinte, em geral, ocorre alinhamento das partículas paralelamente às paredes da zona de cisalhamento. Também ocorrem alinhamentos oblíquos às paredes, com distribuição análoga à textura s-c, típica de rochas cisalhadas em regime plástico. 


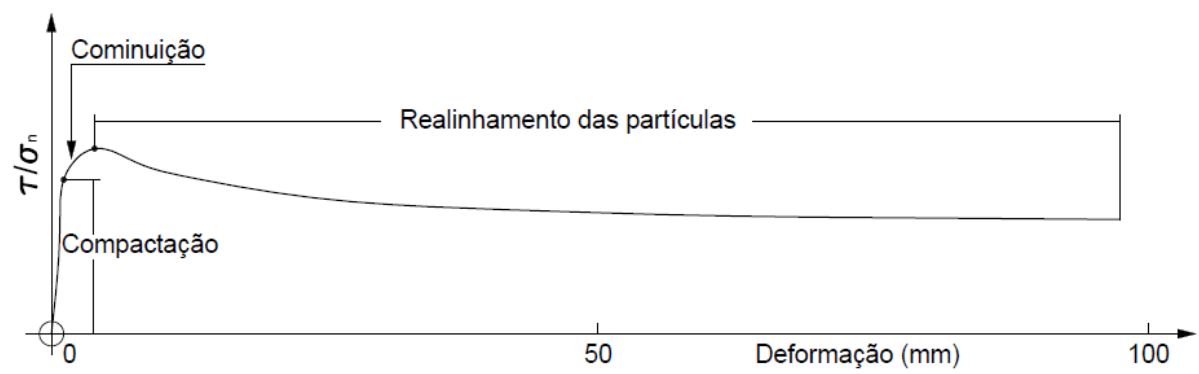

Figura 4. Processos mecânicos durante avanço do cisalhamento. Curva de tensão-deformação em tensão efetiva constante para argilas normalmente consolidadas (adaptado de Skempton, 1985)

\subsubsection{Microestruturas típicas de uma zona de cisalhamento}

Dois dos estudos precursores de análises microestruturais de zonas de cisalhamento são de Tchalenko (1967) e Morgenstern e Tchalenko (1967), que realizaram análises em microscópio óptico e eletrônico de zonas de cisalhamento naturais e de zonas geradas a partir de ensaios laboratoriais. Tchalenko (1967) analisou a microestrutura da zona de cisalhamento de um deslizamento ocorrido em Staffordshire, UK. O autor realizou análises em microscópio óptico em amostras indeformadas. A Figura 5a apresenta um trecho da zona de cisalhamento observada, que é facilmente distinguível de seu entorno, devido a diferença de coloração e alinhamento das partículas. A figura $5 b$ apresenta um esquema das estruturas observadas, com indicação do realinhamento das partículas na zona de cisalhamento e em seu entorno.

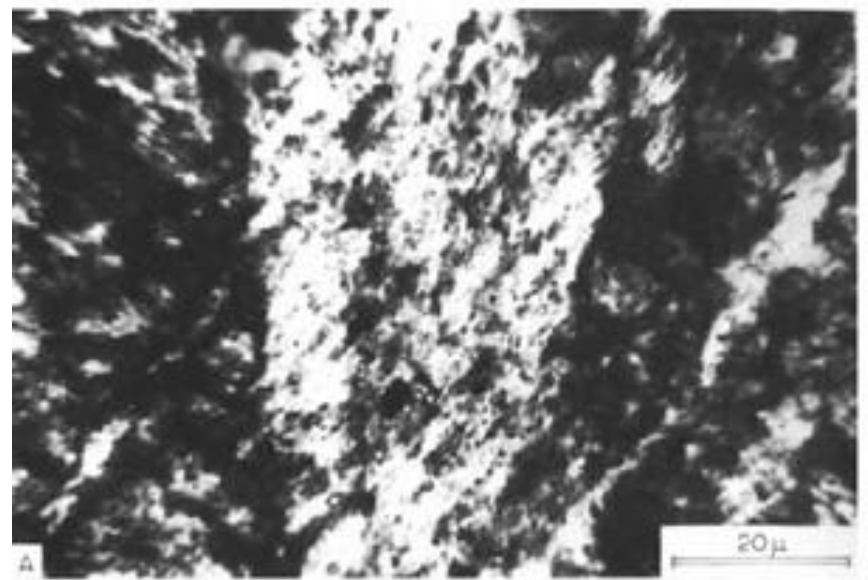

(a)

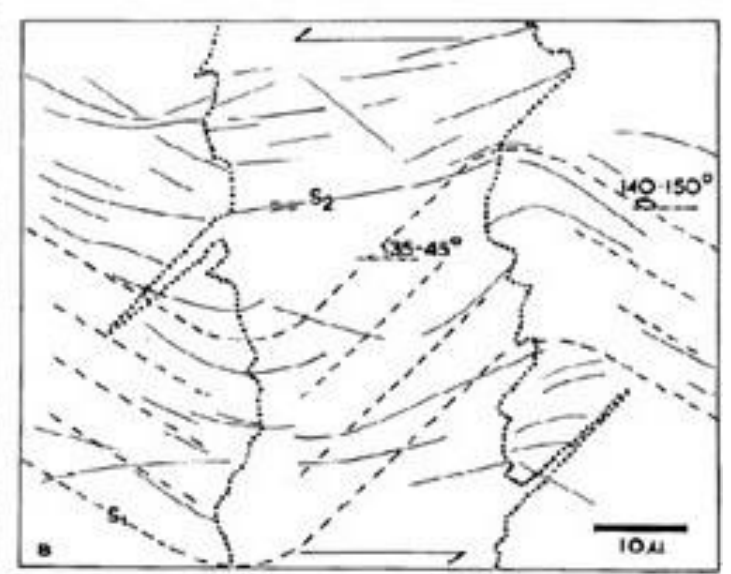

(b)

Figura 5. (a) zona de cisalhamento de em um solo residual de argilito de Staffordshire (UK) visto em microscópio óptico (b) indicação das estruturas de cisalhamento (Kink Bands)

(Tchalenko, 1967)

A Figura 6a ilustra um esquema com maior detalhamento desta zona de cisalhamento, onde observa-se as relações texturais e estruturais da zona e seu entorno. $\mathrm{O}$ autor 
notou presença de alinhamento de partículas oblíquas às paredes da zona de cisalhamento e denominou esta estratificação de "Kink Bands". Na Figura 6b o autor destaca os principais alinhamentos. Há maior presença de descontinuidades próximo às paredes da zona de cisalhamento e ao seu redor, em diferentes direções. Deste modo, o autor mostra que há formação de zonas de cisalhamento menores, conjugadas às paredes da zona de cisalhamento principal.

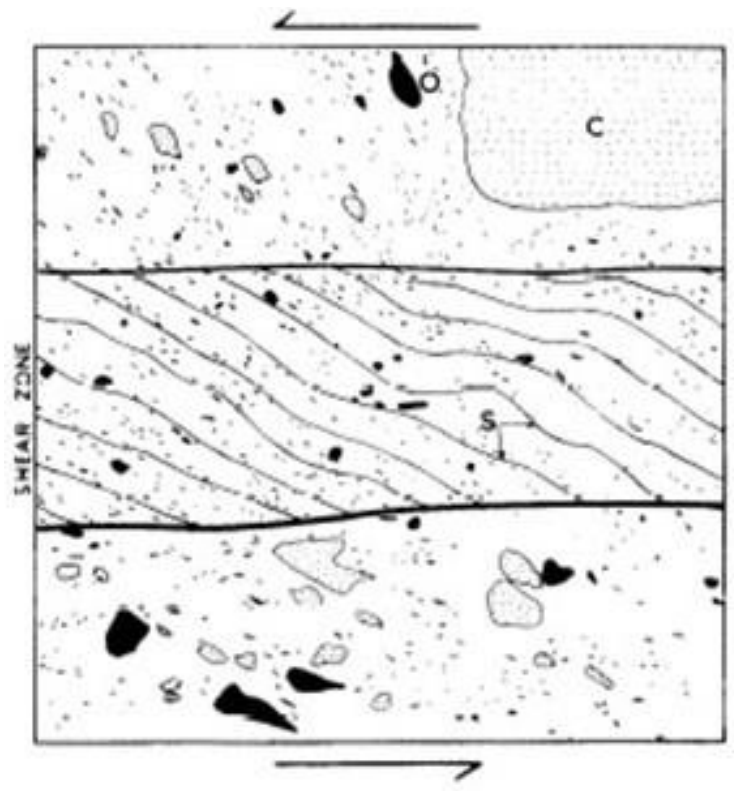

(a)

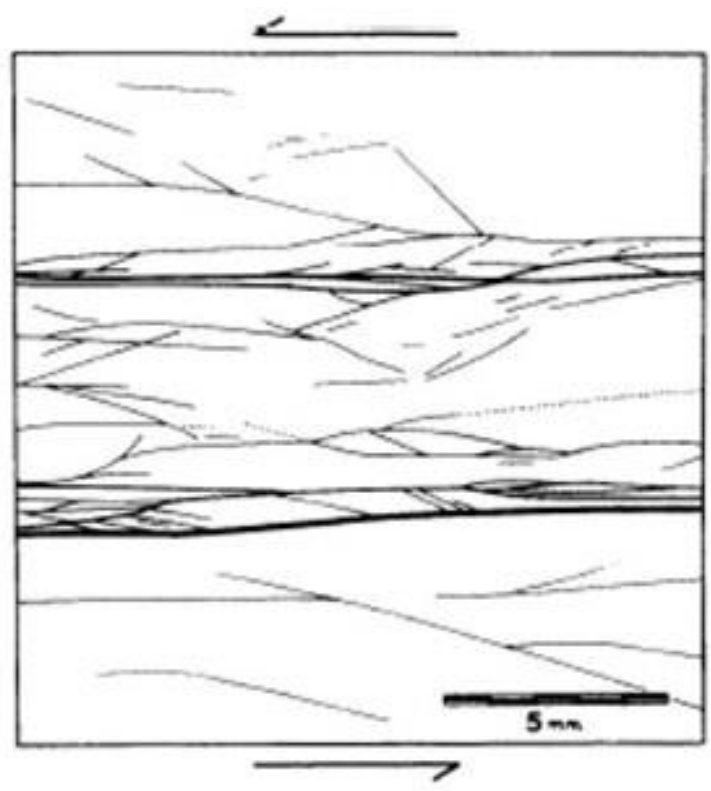

(b)

Figura 6. (a) relações texturais e estruturais de uma zona de cisalhamento em um solo residual de argilito de staffordshire (UK). $\mathrm{C}=$ grumos de argila; $\mathrm{O}=$ matéria orgânica; $\mathbf{S}=$ orientação de partículas (b) descontinuidades geradas por cisalhamento (Tchalenko, 1967)

Morgenstern e Tchalenko (1967) perceberam a semelhança do padrão estrutural das zonas de cisalhamento em rochas, retratado pelo esquema de Riedel, e o adaptou para a utilização em solos. O esquema de Riedel retrata a ocorrência de zonas de cisalhamento menores conjugadas, que se formam sequencialmente ao longo de uma zona de cisalhamento principal. A experiência de Riedel (publicada em 1929) é descrita em Tchalenko (1970). Nesta experiência, o autor observa a sequência de formação de falhas conjugadas durante um cisalhamento, em um ensaio análogo ao ensaio de cisalhamento direto atual.

A Figura 7a apresenta as relações típicas entre as zonas de cisalhamento menores, descritas por Riedel, e a zona de cisalhamento principal (PDS - Principal Displacement Shear), onde $\varphi$ é o ângulo de atrito do solo e R, R', P e T representam 
as direções de cisalhamento menores. Os ângulos ilustrados no esquema são válidos assumindo ação de cisalhamento simples e que as tensões aplicadas são coaxiais.

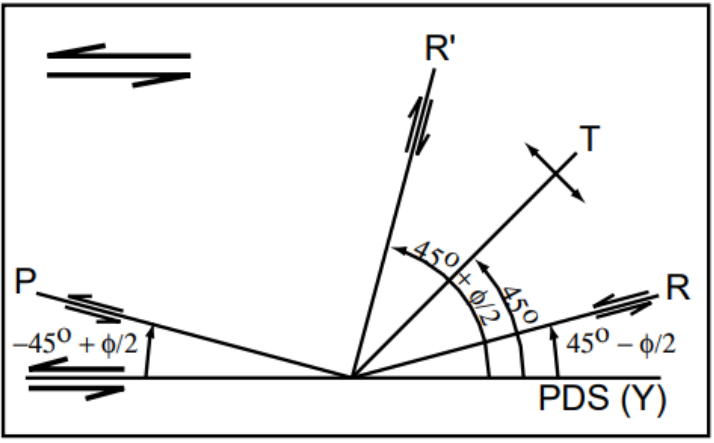

Figura 7. Relações de zonas de cisalhamento de Riedel (PDS - Principal Displacement Shear) (Ahlgren, 2001)

De acordo com Gylland et al (2013), a formação das direções de cisalhamento menores ocorre ao longo do desenvolvimento da deformação do solo. As zonas de cisalhamento sintéticas do tipo $\mathrm{R}$ são as primeiras a serem formadas durante 0 carregamento axial e são seguidas pelas zonas antitéticas R'. Com o aumento da deformação, as zonas $P$ são formadas. Apenas, após a formação destas zonas menores, a zona de cisalhamento principal se apresente em condições cinemáticas que permite o deslizamento do plano de ruptura. Também pode ocorrer zonas $T$, como resposta tensional ao carregamento. A Figura 8 apresenta a formação idealizada de uma zona de cisalhamento.

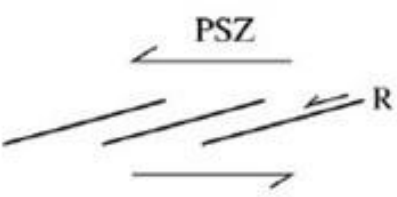

(a)

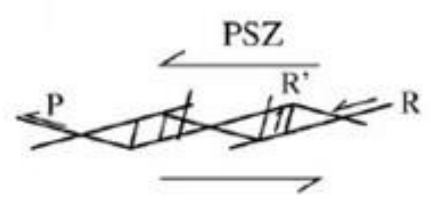

(c)

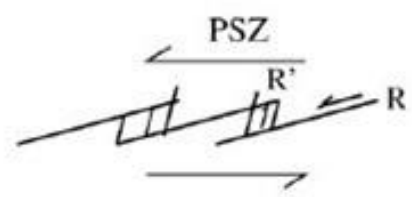

(b)

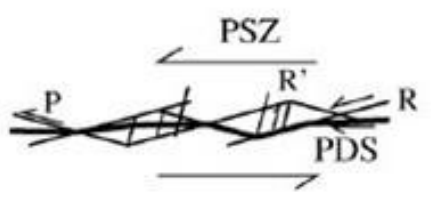

(d)

Figura 8. Desenvolvimento de uma zona de cisalhamento (a) desenvolvimento inicial da zona de cisalhamento com formação da direção de cisalhamento menor R; (b) subsequente formação da zona conjugada R'; (c) Zonas P são formadas com elevadas taxas de deformação; (d) formação do plano de ruptura (PDS - principal displacement shear) (Gyllland et al, 2013). 


\subsection{Ensaios Triaxiais Multi-Estágios}

Os parâmetros de resistência de solos podem ser obtidos por meio da execução de ensaios triaxiais convencionais, como descrito no item 2.1, onde três corpos de prova distintos são submetidos à cisalhamento, sob diferentes tensões de adensamento. $\mathrm{A}$ qualidade dos resultados obtidos em ensaios triaxiais convencionais depende da qualidade dos corpos de prova ensaiados e da representatividade da amostra. Para a obtenção de bons resultados, recomenda-se a utilização de três corpos de prova tão idênticos quanto possível, para que diferenças composicionais e estruturais das amostras não afetem a estimativa dos parâmetros de resistência do solo, que são obtidos através da interpolação de dados obtidos em diferentes corpos de prova ensaiados.

Entretanto, a obtenção de corpos de prova idênticos é muito difícil. Grande parte dos solos naturais são caracterizados por apresentar grande heterogeneidade. Por exemplo, a existência de estruturas herdadas da rocha-mãe em solos residuais fornece elevada heterogeneidade a este tipo de solo, o que dificulta a determinação de suas características em ensaios laboratoriais, pois corpos de prova retirados de uma mesma amostra podem apresentar características muito distintas (Pinto, 2006).

Devido à natureza heterogênea dos solos, uma boa amostragem demanda estudos preliminares do solo a ser estudado e pode exigir grande tempo de coleta e custos muito elevados. Com esta dificuldade, foi desenvolvida a técnica multi-estágio para a determinação dos parâmetros de resistência dos solos (e.g. Ho e Fredlund, 1982). ensaio triaxial multi-estágio (ou ensaio triaxial múltiplo) permite a obtenção dos parâmetros de resistência de um solo utilizando um único corpo de prova. Este tipo de ensaio é realizado submetendo uma amostra à cisalhamento, em diferentes pressões confinantes, sem mobilização máxima da tensão de ruptura até o último estágio do teste.

Lumb (1964) e Saeedy e Mollah (1988) discutem detalhadamente as vantagens e desvantagens da utilização da técnica multi-estágio. A execução do ensaio triaxial multi-estágio elimina a necessidade de interpolação de dados obtidos em amostras distintas, trazendo resultados com maior confiabilidade no caso de solos heterogêneos. Outra vantagem na utilização desta técnica é a redução do tempo necessário para coleta e preparação de amostras. A moldagem de corpos de prova 
indeformados, de solos muito cimentados ou de areias saturadas, por exemplo, é de difícil execução e pode demandar elevados custos e grande tempo de preparação. $O$ método multi-estágio também implica na diminuição do tempo necessário para a realização do ensaio, o que pode ser muito vantajoso na otimização de projetos geotécnicos.

Além disso, a diminuição do número de amostras necessárias para ensaio permite a realização de uma campanha de amostragem mais detalhada. A coleta de um único corpo de prova em cada horizonte do solo permite uma caracterização completa do terreno a ser estudado. Dessa forma, esta técnica facilita a verificação do efeito da variabilidade do solo na determinação de seus parâmetros de resistência.

Apesar do grande potencial econômico e aplicabilidade desta técnica, esta metodologia ainda é pouco utilizada devido, essencialmente, à falta de normatização dos procedimentos de ensaio. Além disso, a viabilidade dos ensaios do tipo multiestágio ainda é discutida por alguns autores. A metodologia do ensaio exige a execução de estágios sucessivos de cisalhamento em um mesmo corpo de prova, o que possibilita a ocorrência de deformações acumuladas, que pode acarretar na mudança da estrutura da amostra a cada estágio, afetando a determinação acurada dos parâmetros de resistência. Leroueil (apud Khosravi et al, 2011) não recomenda a realização de ensaios triaxiais multi-estágios em amostras indeformadas, pois durante as etapas de cisalhamento pode ocorrer rompimento das ligações por cimentação, realinhamento das partículas de argila, mudanças nos índices de vazios e quebra de grãos.

Apesar destes questionamentos, diversos autores compararam os parâmetros de resistência obtidos em ensaios convencionais e em ensaios múltiplos e observaram bons resultados, com envoltórias de ruptura correlacionáveis (Kenney e Watson, 1961; Parry e Nadarajah,1973; Kim e Ko, 1979; Ho e Fredlund,1982; Kovari et al, 1983; Nambiar et al, 1985; Shields et al,1985, dentre outros).

\subsubsection{Metodologia de execução de ensaios triaxiais multi-estágios}

Um ensaio triaxial multi-estágio é realizado submetendo um único corpo de prova a três ou mais etapas de cisalhamento, sob diferentes tensões de adensamento, sem que a máxima tensão desviadora seja induzida até o último estágio do teste. Trata-se de uma técnica utilizada desde a década de 50 (e.g. De Beer, 1950 e Taylor, 1950). 
Desde então, foram testadas diversas variações desta técnica, desenvolvidas para diferentes tipos de solo e de acordo com a evolução tecnológica dos equipamentos triaxiais. Estas variações distinguem-se entre si nos seguintes aspectos:

- Definição do momento de paralisação do cisalhamento nos estágios iniciais e intermediários;

- Manutenção ou retirada da carga axial durante as fases de adensamento intermediárias;

Os itens a seguir discutirão detalhadamente cada um destes aspectos, apresentando as metodologias de execução desenvolvidas ao longo do tempo.

2.3.1.1. Determinação dos critérios de paralisação dos estágios de cisalhamento iniciais

A maior dificuldade na execução dos ensaios múltiplos é a determinação do critério de paralisação dos estágios de cisalhamento nos ensaios múltiplos. Os estágios intermediários de cisalhamento devem ser continuados até que os parâmetros de resistência possam ser totalmente mobilizados. Porém, o carregamento axial deve ser interrompido antes que ocorra rompimento do corpo de prova ou que ocorram taxas de deformações elevadas, que possam interferir nos resultados dos estágios subsequentes.

De acordo com Kenney e Watson (1961), o rompimento de um corpo de prova pode ser identificado, em ensaios convencionais, quando a tensão desviadora ( $\sigma_{1}{ }^{\prime}-\sigma_{3}$ ') ou a tensão axial normatizada $\left(\sigma_{1}^{\prime} / \sigma_{3}^{\prime}\right)$ atinge o valor máximo, para ensaios drenados. Para ensaios não drenados em solos normalmente adensados, a ruptura pode ser identificada apenas no ponto máximo da tensão axial normatizada ( $\sigma_{1}$ / $\sigma_{3}$ máx). Já para ensaios não drenados em solos sobreadensados, o ponto exato de ruptura não pode ser definido. Segundo os autores, como a distinção entre solos sobreadensados e normalmente consolidados é muito difícil, considera-se que a ruptura só pode ser determinada com sucesso em ensaios drenados. Dessa forma, em ensaios triaxiais multi-estágios, em especial os não drenados, não é possível determinar o ponto exato de ruptura, necessário para a definição do ponto de paralisação dos estágios de cisalhamento. Porém, é necessário progredir com o carregamento até que os parâmetros de resistência sejam totalmente mobilizados. 
Com o objetivo de se avaliar taxas de deformações mínimas que permitem a mobilização total dos parâmetros de resistência (Ф' e c'), Kenney e Watson (1961) realizaram ensaios triaxiais convencionais e multi-estágios drenados e não drenados em areias e argilas sobreadensadas e normalmente adensadas e comparam os resultados, medindo o grau de mobilização dos parâmetros de resistência. $\mathrm{O}$ grau de mobilização $(M)$ foi calculado como uma relação entre o ângulo de atrito ( $\Phi^{\prime}$ máx) ou coesão (c' máx) máximo, obtido em ensaios convencionais, e o ângulo de atrito ( $\Phi^{\prime}$ a) ou coesão ( $c$ ' a) obtidos nos ensaios multi-estágios, como indicado nas equações $3 \mathrm{e}$ 4.

$$
\begin{aligned}
& M=\frac{\tan \Phi^{\prime} \max }{\tan \Phi^{\prime} a} \\
& M=\frac{c^{\prime} \text { máx }}{c^{\prime} a}
\end{aligned}
$$

Para as amostras analisadas pelos autores, os parâmetros de resistência foram totalmente mobilizados em ensaios multi-estágios. Em ensaios drenados a mobilização total ocorreu com deformações abaixo de $15 \%$ e para ensaios não drenados, a mobilização ocorreu abaixo de $10 \%$. Além disso, os autores observaram que, em ensaios drenados, a mobilização total dos parâmetros de resistência é independente da sensibilidade e composição mineralógica dos solos. Em ensaios drenados, a mobilização dos parâmetros de resistência é dependente da sensibilidade dos solos, devido às variações de volume ao longo do ensaio. Nestes testes, solos rígidos e insensitivos romperam com menores taxas de deformação e menores variações de volumes do que solos moles e sensíveis.

Tendo em vista a dificuldade de determinação do momento de ruptura e de total mobilização dos parâmetros de resistência, como apontado por Kenney e Watson (1961), diversos autores sugeriram critérios para a paralisação dos estágios de cisalhamento em ensaios triaxiais multi-estágios.

A Tabela 1 apresenta uma síntese dos trabalhos que propuseram ou testaram métodos de execução de ensaios triaxiais multi-estágios. Para cada estudo, há indicação do tipo de ensaio, do tipo de solo e dos critérios de paralisação adotados por cada autor. 
Tabela 1. Critérios de paralisação já utilizados em ensaios multi-estágios

\begin{tabular}{lll} 
Autor Tipo de ensaio Tipo de solo/rocha & $\begin{array}{l}\text { Critério de paralização entre estágios } \\
\text { intermediários }\end{array}$ \\
\hline
\end{tabular}

\begin{tabular}{llll}
\hline $\begin{array}{l}\text { Kenney e Watson } \\
\text { (1961) }\end{array}$ & CD e CU & $\begin{array}{l}\text { Argilas (normalmente } \\
\text { adensadas e } \\
\text { sobreadensadas) e areias }\end{array}$ & $\begin{array}{l}\text { Carga axial é aplicada até uma deformação } \\
\text { definida previamente }\end{array}$ \\
\hline
\end{tabular}

$\begin{aligned} & \text { Parry e Nadarajah } \\ & (1973)\end{aligned}$
$\begin{aligned} & \text { (19) } \\ & \text { Argilas sobreadensadas }\end{aligned}$ $\begin{aligned} & \text { Máxima tensão desviadora: curva tensão- } \\ & \text { deformação se torna horizontal }\left(\mathrm{dq} / \mathrm{d} \varepsilon_{\mathrm{a}}=0\right)\end{aligned}$

\begin{tabular}{lll}
\hline Kim e Ko (1979) Não especificado Arenitos e xisto & $\begin{array}{l}\text { Máxima tensão desviadora: curva tensão- } \\
\text { deformação se torna horizontal }\left(\mathrm{dq} / \mathrm{d} \varepsilon_{\mathrm{a}}=0\right)\end{array}$ \\
\hline
\end{tabular}

\begin{tabular}{lll}
\hline $\begin{array}{l}\text { Ho e Fredlund } \\
(1982)\end{array}$ & $\begin{array}{l}\text { CD com controle de Solos residuais de riolito e } \\
\text { sucção }\end{array}$ & $\begin{array}{l}\text { Máxima tensão desviadora: curva tensão- } \\
\text { granito insaturados }\end{array}$ \\
\hline Nambiar et al (1985) CIU & $\begin{array}{l}\text { Sedimentos marinhos da se torna horizontal }\left(\mathrm{dq} / \mathrm{d} \varepsilon_{\mathrm{a}}=0\right) \\
\text { costa oeste indiana }\end{array}$ & $\begin{array}{l}\text { Carga axial é aplicada até uma deformação } \\
\text { definida previamente e tensões de ruptura são } \\
\text { inferidas por modelo hiperbólico de Kondner } \\
(1963)\end{array}$ \\
\hline
\end{tabular}

\begin{tabular}{llll}
$\begin{array}{l}\text { Crawford e Wylie } \\
(1987)\end{array}$ & CD & Arenito & Ponto crítico $(\mathcal{E V}=0)$ \\
\hline $\begin{array}{l}\text { Saeedy e Mollah } \\
(1988)\end{array}$ & CD e CU & Sedimentos síltíco-arenosos & $\begin{array}{l}\text { Duas leituras consecutivas com aumento } \\
\text { menor de } 0,05 \% \text { na tensão desviadora }\end{array}$ \\
\hline
\end{tabular}

\begin{tabular}{|c|c|c|c|}
\hline $\begin{array}{l}\text { Schoenemann e } \\
\text { Pyles (1988) }\end{array}$ & CAU e CIU & $\begin{array}{l}\text { Solo residual e coluvionar de } \\
\text { basalto }\end{array}$ & $\begin{array}{l}\text { Ponto onde a trajetória de tensões intercepta a } \\
\text { envoltória de ruptura, inferida no primeiro } \\
\text { estágio do teste }\end{array}$ \\
\hline
\end{tabular}

$\begin{array}{llll}\begin{array}{l}\text { Rahardjo et al } \\ (1995)\end{array} & \begin{array}{l}\text { CD e CU com } \\ \text { controle de sucção }\end{array} & \begin{array}{l}\text { Argilas siltosas e siltes } \\ \text { argilos sedimentares }\end{array} & \begin{array}{l}\text { Máxima tensão desviadora: curva tensão- } \\ \text { deformação se torna horizontal }\left(\mathrm{dq} / \mathrm{d} \varepsilon_{\mathrm{a}}=0\right)\end{array}\end{array}$

Pagoulatos (2004) CD Arenito $\quad \mathrm{d} \varepsilon \mathrm{v} / \mathrm{dq}=0$

Sharma et al (2011) CD

Areias pouco cimentadas $\quad \mathrm{d} \varepsilon \mathrm{v} / \mathrm{dq}=0$ para estágios iniciais e $\varepsilon v=0$ para (cimentadas artificialmente) o último estágio

\begin{tabular}{|c|c|c|c|}
\hline $\begin{array}{l}\text { Khosravi et al } \\
\text { (2011) }\end{array}$ & $\begin{array}{l}\text { CD com controle de } \\
\text { sucção }\end{array}$ & $\begin{array}{l}\text { Areia siltosa compactada e } \\
\text { insaturada }\end{array}$ & $\begin{array}{l}\text { Ponto onde a trajetória de tensões intercepta a } \\
\text { envoltória de ruptura e a linha do estado crítico }\end{array}$ \\
\hline $\begin{array}{l}\text { Hormdee et al } \\
(2012)\end{array}$ & $\begin{array}{l}\text { Cisalhamento } \\
\text { direto* }\end{array}$ & Sedimentos compactados & $\begin{array}{l}\text { Carga axial é aplicada até uma deformação } \\
\text { definida previamente e tensões de ruptura são } \\
\text { inferidas por modelo hiperbólico de Kondner } \\
\text { (1963) }\end{array}$ \\
\hline
\end{tabular}

Ferreira (2016)
Rejeito de mineração: Inert

Steel Aggregate for

Construction (ISAC)
Máxima tensão desviadora: curva tensãodeformação se torna horizontal $\left(\mathrm{dq} / \mathrm{d} \varepsilon_{\mathrm{a}}=0\right)$ 
A Figura 9 ilustra os critérios de paralisação citados na Tabela 1. O desenvolvimento e a utilização de cada um destes critérios serão explicitadas nos parágrafos a seguir.

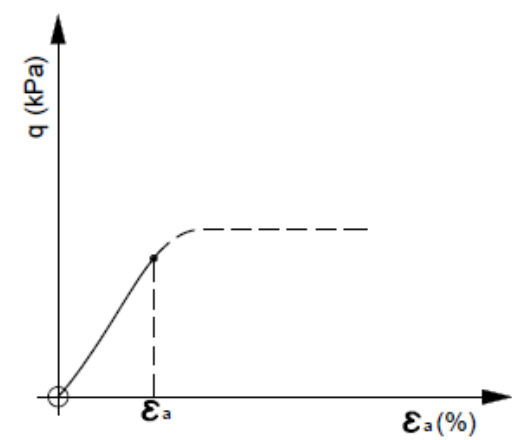

(a)

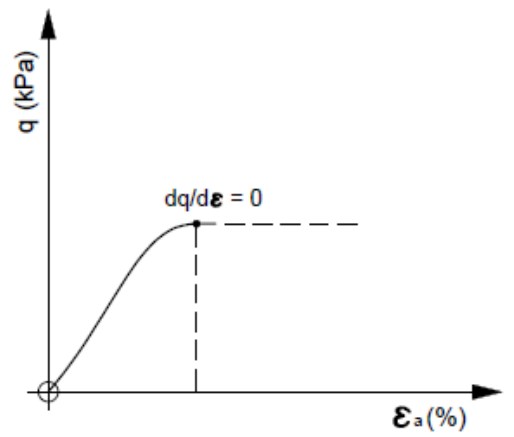

(b)

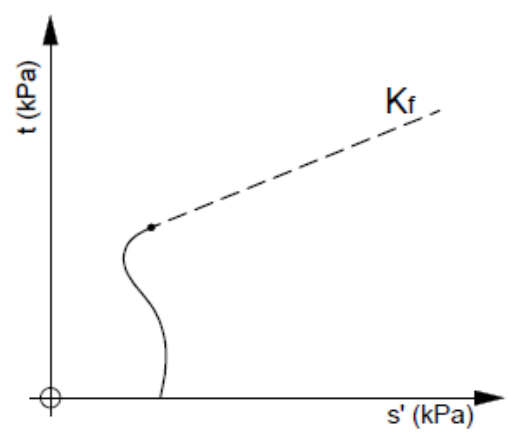

(c)

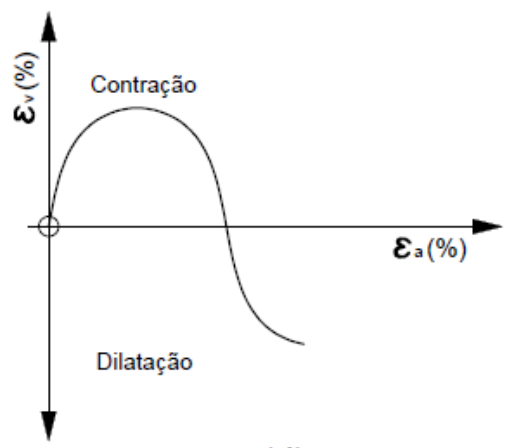

(d)

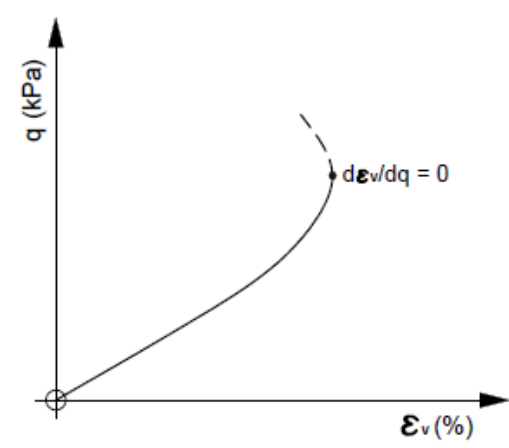

(e)

Figura 9. Critérios de paralisação de estágios intermediários utilizados em ensaios triaxiais multi-estágios. (a) paralisação em deformação definida previamente; (b) máxima tensão desviadora $\left(\mathrm{dq} / \mathrm{d} \varepsilon_{\mathrm{a}}=0\right)$; (c) ponto onde a trajetória de tensões muda de direção e se estabiliza em uma tangente; (d) ponto crítico $\left(\varepsilon_{\mathrm{v}}=0\right)$; (e) $d \varepsilon_{\mathrm{v}} / \mathrm{dq}=0$ (adaptado de Sharma et al, 2011)

A metodologia de execução tradicional, publicada primeiramente por Beer (1950) e testada por Parry e Nadarajah (1973), Kim e Ko (1979), Ho e Fredlund (1982), Rahardjo et al (1995), Ferreira (2016), entre outros, apresenta como critério de paralisação dos estágios de cisalhamento o ponto onde a curva de tensão-deformação torna-se horizontal $\left(d q / d \varepsilon_{a}=0\right)$. Este ponto representa o pico de tensão desviadora e, de acordo com os autores, representa o limiar da ruptura do solo.

Neste método, após a interrupção do cisalhamento, a tensão axial é totalmente removida e, posteriormente, a tensão efetiva é lentamente elevada para a realização da próxima etapa de cisalhamento. Este procedimento é repetido no mínimo três vezes, e no último estágio o carregamento é realizado até o rompimento do corpo de prova. Para o tratamento dos dados, estes autores consideraram os pontos de paralisação dos estágios como a tensão de ruptura e os parâmetros de resistência são calculados utilizando as tensões efetivas máxima $\left(\sigma 1^{\prime}\right)$ e mínima $\left(\sigma 3^{\prime}\right)$ deste ponto. 
Este critério foi testado em diversos tipos de solo e apresentaram resultados com boa aproximação com os obtidos nos ensaios convencionais. Porém, Ho e Fredlund (1982), que testaram a aplicação desta metodologia em ensaios múltiplos tipo CD com medida de sucção em solos residuais insaturados, observaram que os picos de resistência nos últimos estágios de cisalhamento apresentados nos ensaios multiestágio foram menores do que os obtidos nos ensaios convencionais. Esta perda de resistência, ocorrida no último estágio de cisalhamento, está relacionada com a perturbação da estrutura da amostra e a deformação acumulada ocorrida durante os estágios iniciais. Por isso, esta metodologia de ensaio não é indicada para solos sensíveis e solos pouco cimentados (Pagoulatos, 2004).

Para quantificar esta queda de resistência, Kim e Ko (1979) realizaram dois tipos de teste em amostras de xistos. Um dos métodos utilizado por Kim e Ko consiste em realizar cisalhamentos consecutivos (com carregamento e descarregamento axial) com tensão confinante constante. O outro método consiste em realizar o primeiro e o terceiro estágio de cisalhamento com a mesma tensão confinante e realizar o segundo estágio com uma tensão confinante maior. Esperava-se que os ensaios repetidos na mesma tensão confinante que a utilizada no estágio inicial apresentassem o mesmo comportamento, com picos de tensão aproximados. A Figura 10 apresenta gráficos de tensão-deformação para ilustrar os métodos de ensaio de Kim e Ko (1979)

Os autores observaram que os picos de resistência obtidos com a mesma tensão confinante, em ambos os métodos, apresentam diferenças baixas, menores de $5 \%$, concluindo que as quedas de resistência, ocorrida por perturbações no corpo de prova ao longo do ensaio multi-estágio, entram na margem de erro dos ensaios laboratoriais e podem ser ignoradas para os tipos de rocha analisadas. 


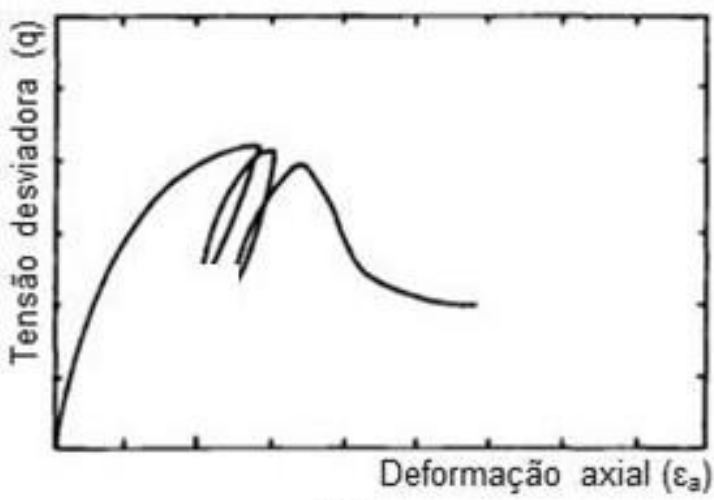

(a)

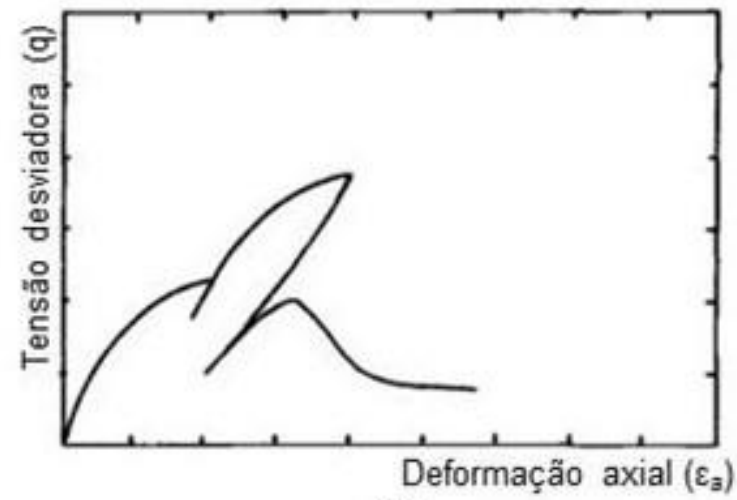

(b)

Figura 10: Esquema dos testes realizados por Kim e Ko. (a) estágios de cisalhamento consecutivos com pressão confinante constante; (b) teste realizado com primeiro e terceiro estágio de cisalhamento com a mesma tensão confinante e segundo estágio de cisalhamento executado com uma tensão confinante maior (adaptado de Kim e Ko, 1979)

Para reduzir o efeito da deformação acumulada em ensaios multi-estágios em solos sensíveis, Sridharan e Narasimha Rao (1972, apud Hormdee et al, 2012) realizaram os estágios de cisalhamento com carregamentos axiais levados até pequenas deformações definidas previamente. Os parâmetros de resistência foram obtidos utilizando o modelo hiperbólico de Kondner (1963), que permite a estimativa da tensão desviadora e da poro-pressão no momento de ruptura. Os autores obtiveram parâmetros de resistência com boa aproximação com os ensaios convencionais. Porém, os valores de tensão desviadora máxima foram superestimados.

Hormdee et al (2012) testou o método desenvolvido por Sridharan e Narasimha Rao (1972) em ensaios de cisalhamento direto utilizando a técnica multi-estágio em sedimentos e obteve estimativas de parâmetros de resistência compatíveis com os obtidos em ensaios de cisalhamento direto convencionais.

Os autores Schoenemann e Pyles (1988) utilizaram o comportamento das trajetórias de tensões ao longo do ensaio para determinar os pontos de ruptura. Neste método, o estágio é paralisado quando a trajetória de tensões toca a envoltória de ruptura, definida nos estágios iniciais do ensaio. De acordo com Schoenemann \& Pyles (1988), a determinação da ruptura no primeiro estágio de cisalhamento é mais difícil, pois a envoltória de ruptura ainda não é determinada. Geralmente, o primeiro estágio é paralisado quando a trajetória de tensões muda de direção e se estabiliza em uma tangente. Nos demais estágios, o cisalhamento é interrompido quando a trajetória de tensões atinge a envoltória de ruptura, determinada no primeiro estágio. 
Crawford e Wylie (1987) realizaram ensaios multi-estágios drenados em arenitos e paralisaram os estágios de cisalhamento no ponto crítico $\left(\varepsilon_{v}=0\right)$, quando o corpo de prova começa a se dilatar após contração. De acordo com Sharma et al (2011) este critério não é recomendado para todos os tipos de solo pois o rompimento do corpo de prova pode ocorrer antes do ponto crítico.

Saeedy e Mollah (1988) realizaram ensaios triaxiais multi-estágios drenados e não drenados em sedimentos silto-arenosos bem cimentados do Kuwait. Os autores utilizaram como critério de paralisação dos estágios intermediários de cisalhamento o ponto onde duas leituras consecutivas, realizadas em intervalos de tempo constantes, indicavam aumento irrisório (menor que $0,05 \%$ ) na tensão desviadora. Os autores obtiveram parâmetros de resistência consistentes com os obtidos em ensaios convencionais. Porém, salientam que para determinados tipos de solos, como areias mal cimentadas, por exemplo, o carregamento axial levado até o limiar da ruptura pode gerar colapso da estrutura e causar severos problemas na estimativa da tensão de ruptura nos últimos estágios de cisalhamento.

Para evitar o excesso de deformações acumuladas no corpo de prova, Saeedy e Mollah (1988) sugeriram que nos primeiros estágios de cisalhamento, o carregamento axial ocorra até pequenas deformações e paralisados numa deformação definida previamente, e no último estágio, o cisalhamento deve ser continuado até a ruptura do corpo de prova. A envoltória de ruptura é obtida ligando uma reta entre os pontos terminais dos estágios iniciais de cisalhamento, no gráfico de trajetórias de tensões, e posteriormente, ajustando esta reta para cima, para passar no ponto de ruptura do estágio de cisalhamento final, como ilustrado na Figura 11. 


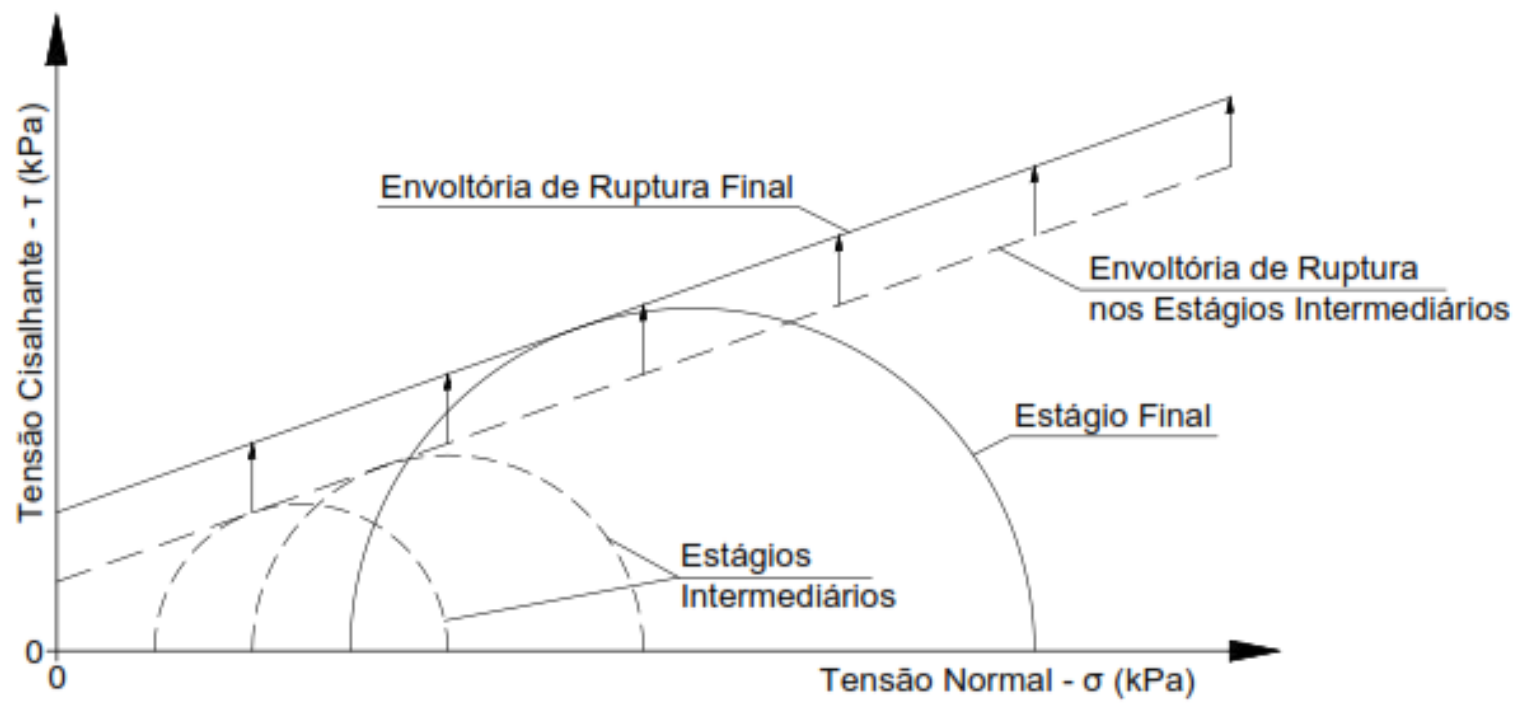

Figura 11: Esquema do método de construção de envoltória de ruptura sugerido por Saeedy \& Mollah (1988).

Pagoulatos (2004) e Sharma et al (2011) aplicaram a técnica proposta por Saeedy e Mollah (1988) em ensaios drenados em areias e arenitos, porém, ambos adotaram como critério de paralisação dos estágios de cisalhamento o ponto de curvatura do gráfico tensão desviadora versus deformação volumétrica $(d \varepsilon v / d q=0)$.

Sharma et al (2011) obtiveram valores de ângulo de atrito consistentes, porém os valores de coesão obtidos foram superestimados, resultando em coesões maiores do que aquelas obtidas em ensaios convencionais. Segundo os autores, este aumento da coesão pode ser ocasionado pelo aumento da densidade da amostra ocorrida devido perturbações durante o carregamento e descarregamento nos estágios iniciais e, consequentemente, elevando o pico da tensão desviadora no rompimento do estágio final.

Para eliminar este problema, os autores testaram também a utilização do ponto crítico $\left(\varepsilon_{v}=0\right)$ como critério de paralisação. A interrupção do carregamento axial neste ponto compensa a densificação do corpo de prova nos estágios preliminares. Com a paralisação dos estágios de cisalhamento no ponto crítico, Sharma et al (2011) obtiveram parâmetros de resistência com boa correlação com resultados de ensaios convencionais, com diferenças médias de $6 \%$ para a coesão efetiva (c') e de $5 \%$ para o ângulo de atrito efetivo ( $\left.\Phi^{\prime}\right)$. 
Khosravi et al (2011) realizaram ensaios multi-estágios com controle de sucção em solos compactados insaturados e utilizou como critério de paralisação dos estágios de cisalhamento um método pioneiro, que baseia-se na relação entre tensão efetiva e variações de taxas de sucção. Neste estudo, os estágios intermediários de cisalhamento foram paralisados no ponto onde a tensão desviadora intercepta a intersecção entre a trajetória de tensões e a curva de estado crítico. Khosravi et al (2011) obtiveram resultados que indicaram que este critério de paralisação é indicado para determinações de tensão de sucção em ensaios multi-estágios.

\subsubsection{Efeito da retirada da carga axial nos estágios de adensamento intermediários}

Outro aspecto a ser levado em conta na execução de ensaios multi-estágios é a decisão de manutenção ou descarregamento da carga axial durante as fases de adensamento, realizadas após os estágios de cisalhamento.

Ho e Fredlund (1982) realizaram ensaios multi-estágios drenados com descarregamento da carga axial e também com a manutenção de carga entre estágios de cisalhamento e compararam os resultados. Os autores sugeriram que a retirada da carga axial entre os estágios de cisalhamento é mais indicada, para evitar excesso de deformação acumulada no corpo de prova. Segundo os autores, a manutenção da carga axial pode causar acomodação dos grãos, alterando a estrutura da amostra. Além disso, os autores ressaltam que retirada da carga axial pode causar restauração de parte da deformação acumulada, através de recuperação elástica.

Schoenemann e Pyles (1988) também executaram ensaios multi-estágios não drenados em um solo residual de basalto com descarregamento e manutenção da carga axial entre fases de cisalhamento. Os autores observaram que a retirada da carga axial pode gerar restauração de parte da deformação acumulada, como citado por Ho e Fredlund (1982). O gráfico tensão-deformação presente na Figura 12 ilustra esta restauração da deformação. Porém, os autores afirmam que o "relaxamento" do corpo de prova pode causar perturbações e quebra da estrutura da amostra, podendo prejudicar a mobilização correta das tensões de ruptura 


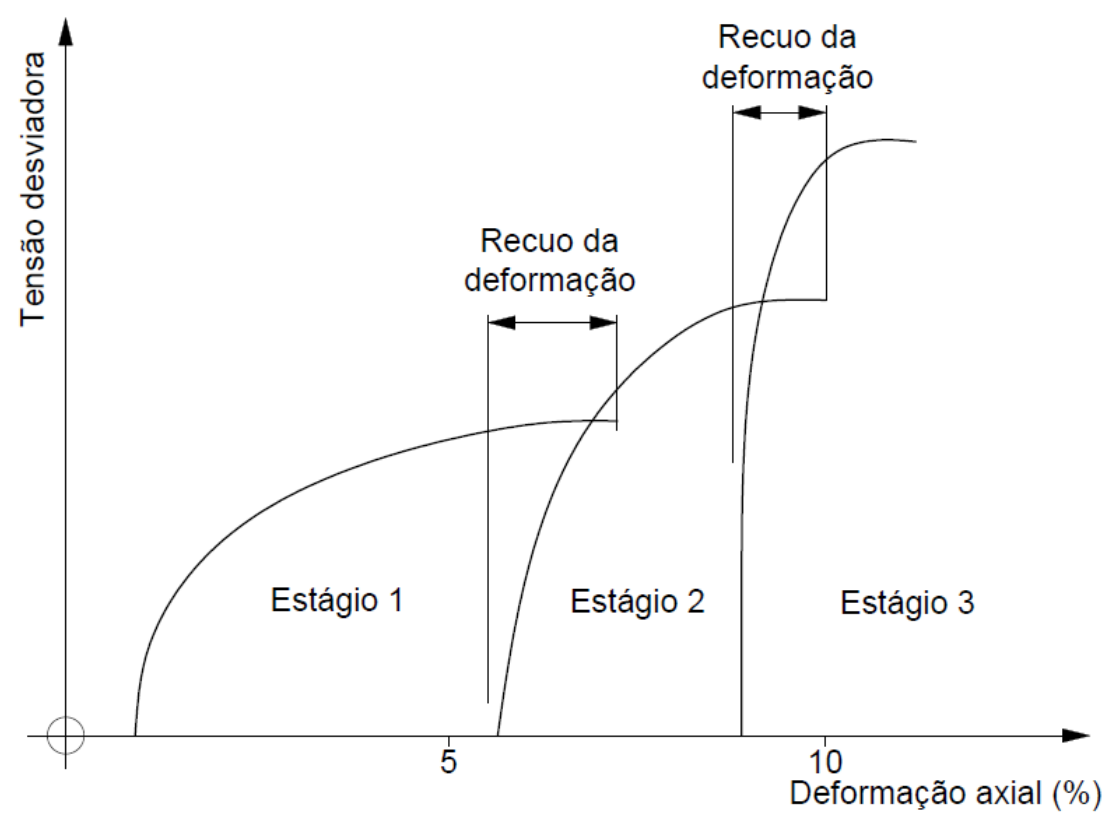

Figura 12: Típica curva tensão-deformação de ensaios triaxiais multi-estágios não drenados, com indicação de restauração da deformação axial entre estágios de cisalhamento, devido retirada de carga axial (adaptado de Schoenemann e Pyles, 1988)

Apesar das advertências quanto a retirada da carga axial após as fases de iniciais de cisalhamento, Schoenemann e Pyles (1988) obtiveram resultados parecidos quando comparam os resultados dos ensaios realizados com retirada da carga axial entre estágios com os ensaios realizados com manutenção de carga e concluíram que, para o solo analisado, a manutenção ou retirada da carga axial é indiferente para a determinação de parâmetros de resistência. Porém, os autores advertiram que esta equivalência não vale para todos os tipos de solos - argilas sensíveis, por exemplo, são menos tolerantes à retirada de carga axial.

\subsubsection{Resultados da literatura e suas interpretações}

Este item tem o objetivo de sintetizar os principais resultados de ensaios triaxiais multiestágios presentes na literatura. Será realizada uma discussão do comportamento tensão-deformação e do comportamento das trajetórias de tensões obtidos em ensaios multi-estágios para os seguintes tipos de solo: solos sedimentares finos (siltosos ou argilosos), solos sedimentares arenosos e solos residuais.

2.3.2.1. Comportamento tensão-deformação e trajetórias de tensões efetivas em solos sedimentares finos (argilosos ou siltosos)

Parry e Nadarajah (1973) realizaram ensaios multi-estágios e convencionais do tipo CAU em argilas sobreadensadas. Os autores realizaram os ensaios em dois tipos de 
amostras: em amostras remoldadas submetidas a tensões de pré-adensamento na câmara triaxial (série A) e em corpos de prova indeformadas (série B). As trajetórias de tensões e os gráficos de tensão-deformação e de variação de pressão neutra obtidos pelos autores estão apresentados Figura 13.
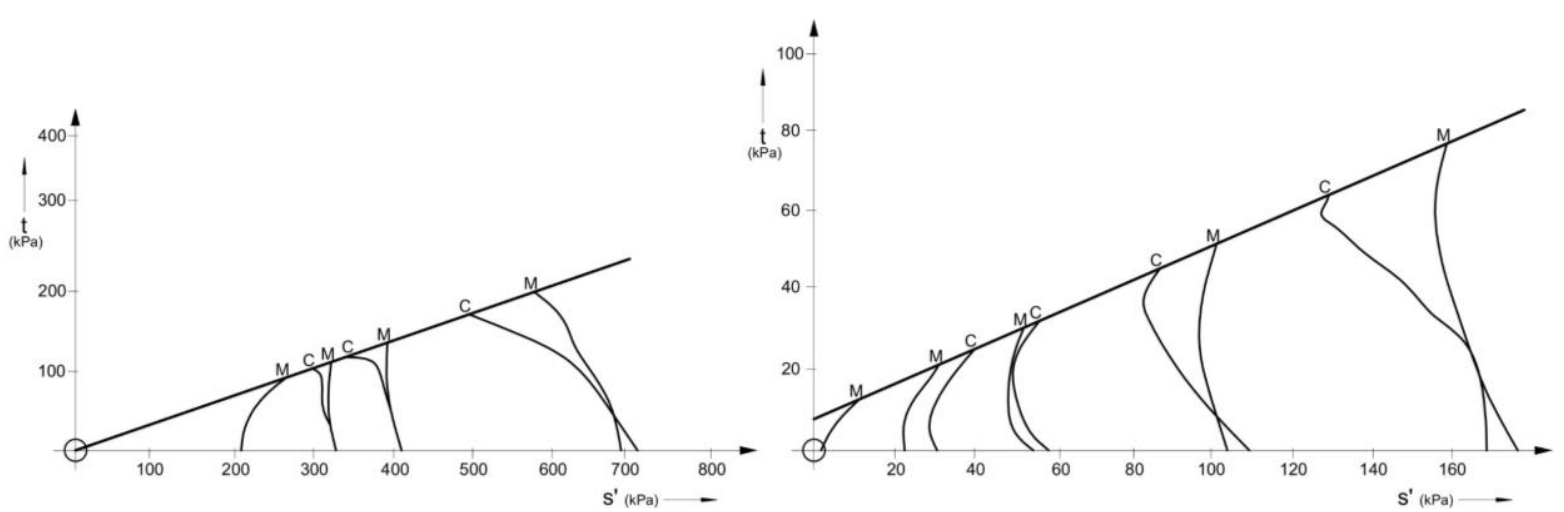

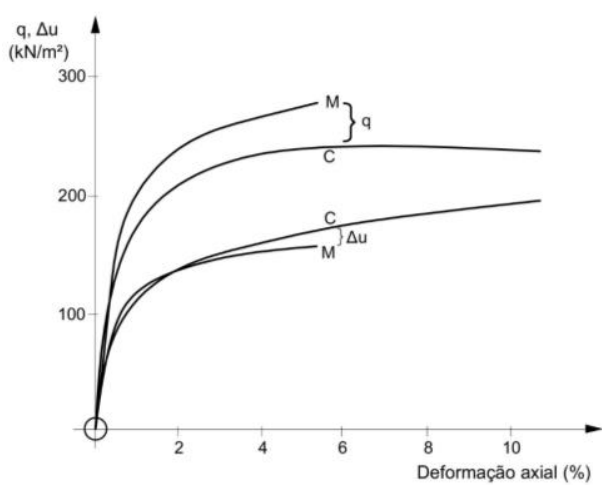

(a)

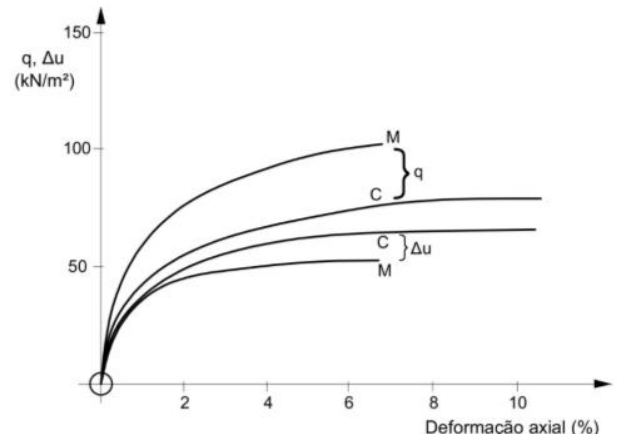

(b)

Figura 13. Diagramas tensão-deformação e trajetórias de tensões de ensaios triaxiais convencionais (C) e multi-estátágios (M). A série A foi realizada em amostras compactadas e artificialmente sobreadensadas e a série $B$ foi realizada em amostras indeformadas (adaptado de Parry e Nadarajah, 1973)

As trajetórias de tensões e os gráficos de tensão-deformação do último estágio do teste evidenciaram que ocorreu menor geração de poro-pressões nos últimos estágios dos ensaios multi-estágios do que nos ensaios convencionais. Observa-se que também ocorreu diferenças nas tensões de ruptura nos dois tipos de ensaio, a ruptura nos últimos estágios dos ensaios multi-estágios ocorreu em níveis de tensões maiores do que nos ensaios convencionais. Os autores acreditam que tais diferenças de comportamento são decorrentes das mudanças estruturais ocorridas durante as fases iniciais e intermediárias de cisalhamento dos ensaios multi-estágios. Não há detalhamento de quais foram as alterações estruturais ocorridas. 
Apesar do comportamento distinto ao longo dos ensaios, a ruptura dos corpos de provas se deu na mesma envoltória, porém, para ensaios multi-estágios, a ruptura se deu em maiores níveis de tensões, como observado na figura 16.

Nambiar et al (1985) realizaram ensaios triaxiais convencionais e multi-estágios em solos marinhos da costa indiana e obtiveram resultados parecidos com os observados por Parry e Nadarajah (1973).

2.3.2.1.1. Comportamento do índice de vazios ao longo de um ensaio multi-estágio não drenado

Uma das preocupações na execução de ensaios triaxiais multi-estágios é a geração de deformações acumuladas devido às fases de cisalhamento intermediárias. $\mathrm{O}$ carregamento axial pode modificar a estrutura da amostra, podendo ocorrer modificações no índice de vazios, quebra de grãos, rompimento de estruturas cimentadas e realinhamento das partículas de argila, alterando o pico de resistência nos estágios posteriores a estas mudanças (Leroueil, 2011, em contato telefônico com Khosravi, 2011).

Para verificar se há a ocorrência de mudanças significativas no índice de vazios devido o carregamento axial nas fases intermediárias de cisalhamento em ensaios multiestágios, Parry e Nadarajah (1973) realizaram ensaios do tipo CAU em argilas sobreadensadas em ensaios múltiplos e convencionais e mediram a variação do índice de vazios nas fases de adensamento em ambos os tipos de ensaios.

Os autores realizaram os testes em duas séries de amostras, sendo uma série de corpos de provas obtidos a partir da compactação de material argiloso (série A) e uma série de amostras indeformadas (série B). As amostras compactadas foram previamente submetidas a tensões radiais e axiais, a fim de se gerar tensões de sobreadensamento nos corpos de prova.

Parry e Nadarajah (1973) calcularam a variação do índice de vazios durante as fases de adensamento a partir da observação da mudança de volume do corpo de prova. Para uma melhor visualização das variações do índice de vazios ao longo dos ensaios, optou-se por analisar a razão $\Delta \mathrm{e} / \mathrm{e}_{0}$, onde $\Delta \mathrm{e}$ reflete as mudanças as mudanças de índices de vazios durante o adensamento e e e é o índice de vazios inicial do corpo de prova. Os resultados obtidos pelos autores estão ilustrados na Figura 14. 


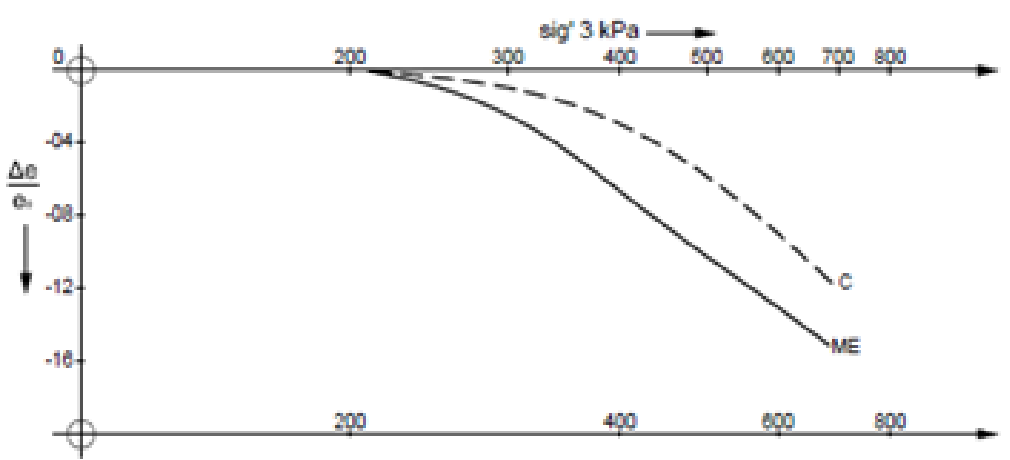

(a)

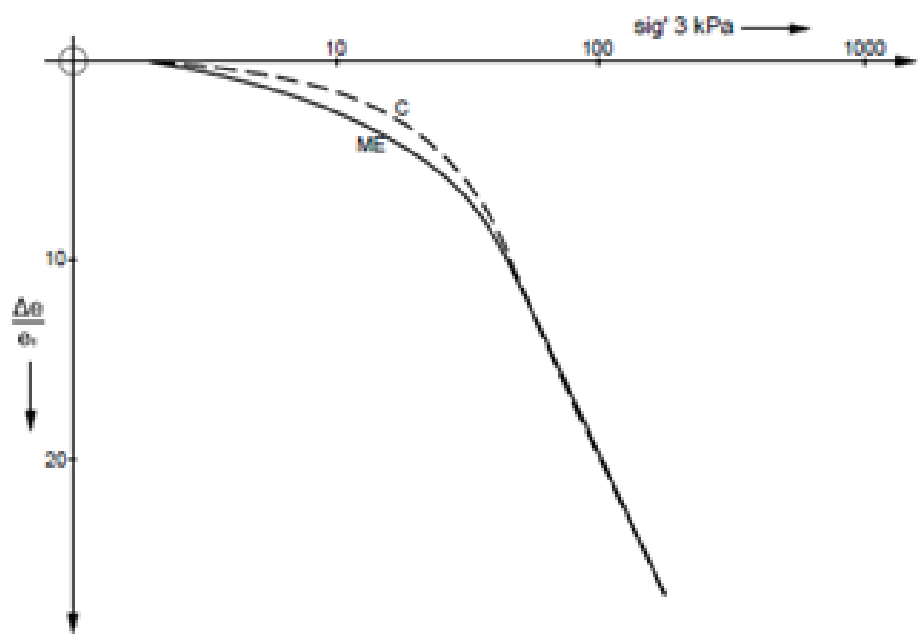

(b)

Figura 14. Variações no índice de vazios (e) com incremento na tensão de adensamento em ensaios convencionais e multi-estágios. $\mathrm{Em}(\mathrm{A})$ resultados para argilas compactadas e sobreadensadas (série A) e em (B) amostras indeformadas (série B) (Parry e Nadarajah,1973).

Como pode ser observado na Figura 14, há uma considerável diferença no comportamento do índice de vazios entre o ensaio convencional e o multi-estágio, na série A. Para estas amostras, ocorreu uma diminuição do índice de vazios mais expressiva nos ensaios multi-estágio, devido ao esforço adicional dos estágios de cisalhamento intermediários. Além disso, no ensaio convencional é possível estimar a tensão de sobreadensamento pela mudança da curvatura da curva, perto de 420 $\mathrm{kN} / \mathrm{m}^{2}$. Já para ensaios multi-estágios, a mudança de curvatura não é tão evidente, dificultando a estimativa da tensão de sobreadensamento. Este fato, demonstra a influência dos estágios de cisalhamento iniciais na estrutura da amostra.

Já para a série $B$, os autores observaram um comportamento coincidente entre os resultados obtidos nos ensaios convencionais e multi-estágio. 
Os autores não discutem o motivo das diferenças de comportamento entre os ensaios multi-estágios das séries A e B. Um possível motivo para tais diferenças é a preservação da cimentação nas amostras indeformadas da série $B$, que dificulta a quebra da estrutura da amostra nos estágios de cisalhamento iniciais.

\subsubsection{Comportamento tensão-deformação em solos sedimentares arenosos}

Ensaios triaxiais multi-estágios foram testados em solos arenosos por Saeedy e Mollah (1988), Rahardjo et al (1995), Pagoulatos (2004), Sharma et al (2011) e Khosravi et al (2011). Há grandes desafios na realização de ensaios multi-estágios em solos arenosos fofos e pouco cimentados, devido a fragilidade de sua estrutura. Os trabalhos consultados apresentam como principal objetivo a definição de um critério de paralisação adequado a este tipo de solo, como discutido no item 2.4.1.3. Saeedy e Mollah (1988) realizaram triaxiais ensaios drenados e não drenados em solos arenosos bem cimentados do Kuwait. Os gráficos com o comportamento tensãodeformação e de variação de volume ou pressão neutra típicos das amostras dos autores estão apresentados na Figura 15, para ensaios drenados e não drenados. 

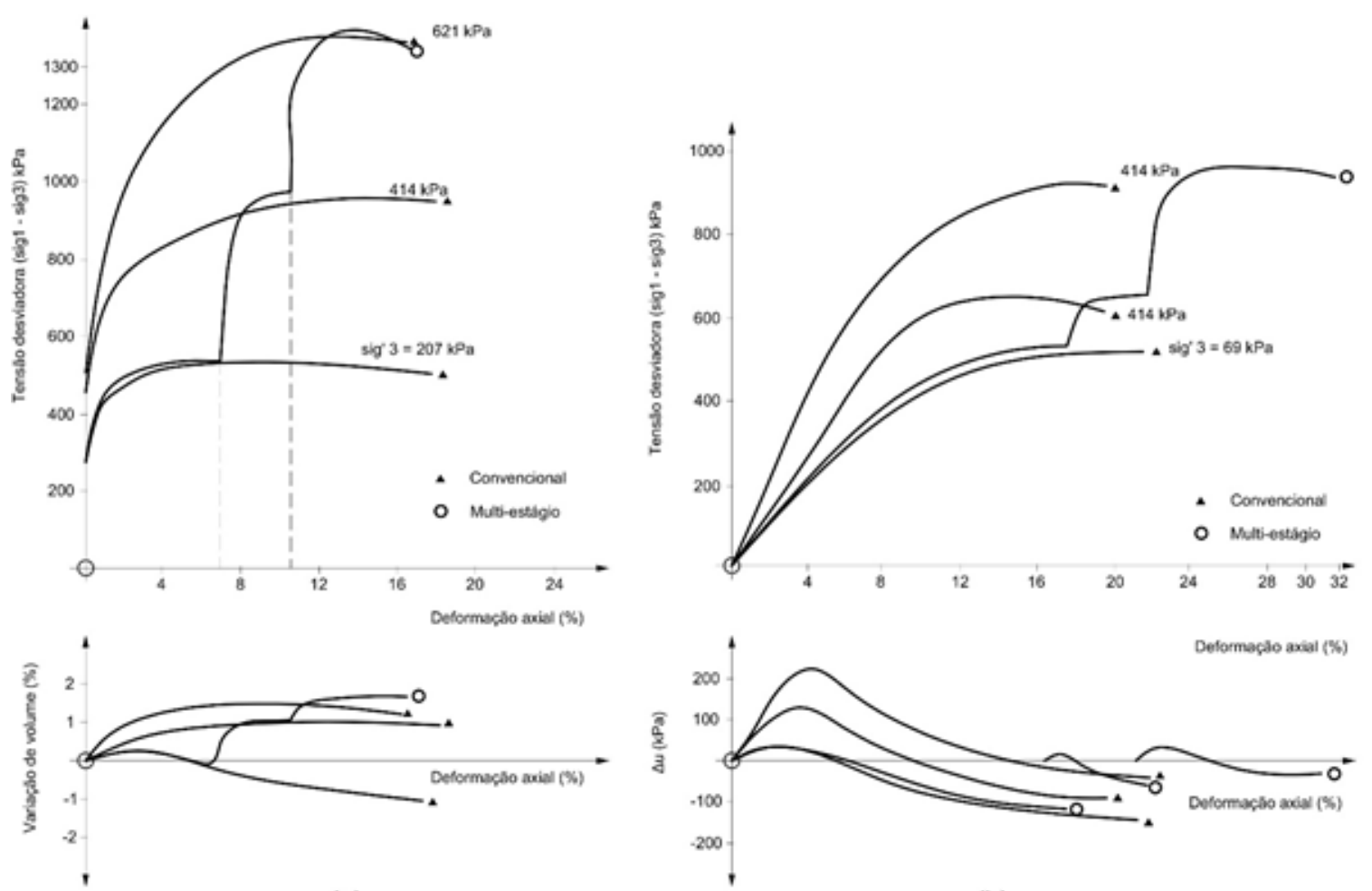

(a)

(b)

Figura 15. (A) Diagramas de tensão-deformação e variação de volume em ensaios convencionais e multi-estágios drenados (B) Diagramas de tensão-deformação e variação de poro-pressões em ensaios convencionais e multi-estágios drenados (Saeedy e Mollah, 1988)

Para os ensaios realizados na condição drenada, houve boa correlação no comportamento tensão-deformação e na variação de volume nos ensaios multiestágios e convencionais. Para ensaios não drenados, ocorreu maior geração de poro-pressões em ensaios convencionais. Já a estabilização da pressão neutra ocorre de forma mais rápida nos ensaios multi-estágios. Os autores atribuem este fato à formação de planos de ruptura nos estágios iniciais de cisalhamento, que facilitam a dissipação das poro-pressões. Apesar das diferenças comportamentais, os parâmetros de resistência obtidos em ensaios multi-estágios em ambas as condições de drenagem são correlacionáveis com os obtidos em ensaios convencionais. Por isso, os ensaios multi-estágios são recomendados para este tipo de solo.

Porém, para solos arenosos fofos e pouco cimentados não se recomenda a execução de ensaios multi-estágios com mobilização total das tensões de rupturas. Sharma et al (2011) testaram paralisar os estágios iniciais e intermediários de cisalhamento no ponto crítico, para compensar a densificação do corpo de prova nos estágios preliminares, e obtiveram bons resultados. Porém, grande parte dos solos arenosos 
rompem anteriormente ao ponto de ruptura. Por isso, este critério de paralisação deve ser utilizado com cautela.

2.3.2.3. Comportamento tensão-deformação e trajetórias de tensões efetivas em solos residuais

Ensaios triaxiais multi-estágios em solos residuais foram testados por Ho e Fredlund (1982), Shoenemann e Pyles (1995) e Rahardjo et al (1995).

Ho e Fredlund (1982) realizaram ensaios convencionais e multi-estágios não drenados em solos residuais de granito e riolito insaturados, com medida de sucção. Os autores obtiveram parâmetros de resistência com boa correlação com os obtidos em ensaios convencionais. A Figura 16 traz um gráfico tensão-deformação de um ensaio CIU realizado em uma amostra de solo residual de granito.

De acordo com os autores, o comportamento típico deste material é a formação de pico de resistência na ruptura, com queda abrupta da tensão desviadora pós-pico. Este comportamento foi observado no último estágio de cisalhamento do ensaio apresentado na Figura 16, mostrando que não ocorreu excesso de deformação nos estágios anteriores, sendo mantida as características intrínsecas do material. Porém, os autores alertam que os estágios de cisalhamento iniciais não devem ser continuados pós-pico, pois pode afetar a estimativa da resistência no estágio final, como observado por Wong (1978, apud Ho e Fredlund, 1982).

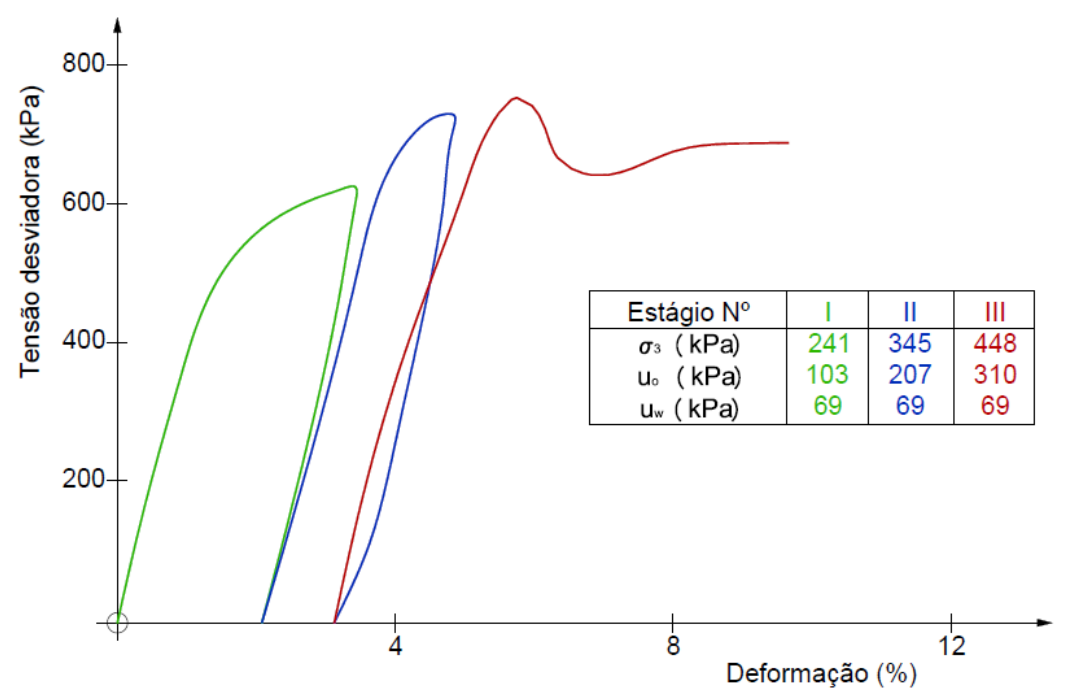

Figura 16. Curvas de tensão-deformação de um ensaio multi-estágio CIU em um solo residual de granito (adaptado de Ho e Fredlund, 1982) 


\subsection{Solos Residuais}

De acordo com Blight (1997), um solo residual pode ser definido como "o material derivado do intemperismo in situ e decomposição de uma rocha que não foi transportado de seu local de origem". As características dos solos residuais são muito variáveis e dependem do tipo da rocha parental e de seu grau de intemperização.

A formação de solos residuais ocorre devido a ação de intemperismo físico, químico e biológico em rochas expostas. O grau de intemperismo de uma rocha depende dos seguintes fatores: clima (temperatura, chuva e grau de evaporação); condições de drenagem; relevo; profundidade da rocha; e tempo, sendo o clima o agente mais preponderante na formação de solos residuais. De acordo com Vaz (1996), o clima é responsável pela definição da espessura e do número de horizontes do solo. Já a composição da rocha parental define a composição mineralógica, granulometria e plasticidade do solo residual.

Ainda segundo Vaz (1996), o grau de decomposição da rocha decresce com o aumento da profundidade, formando um perfil de intemperismo típico para cada conjunto de rocha e clima. Em geral, observa-se presença de rochas sãs em profundidade, que gradam progressivamente para rochas alteradas e solos residuais, com o aumento da cota do terreno. Nas porções superficiais, é comum a presença de materiais secundários (ferro, sílica e saís) gerados por processos de lixiviação e laterização.

No Brasil, um dos perfis de intemperismo adotados na projeção de obras civis é o de Vaz (1996), que subdivide os solos residuais em duas categorias: os solos eluvionares (SE) e os solos de alteração (SA), como ilustrado na Figura 17.

Os solos eluvionares, também conhecidos como solo residuais maduros, são caracterizados por apresentar elevado grau de intemperismo, apresentando-se homogêneos e isotrópicos, com ausência total de texturas e estruturas da rocha parental. Os solos de alteração, ou solos residuais jovens, são constituídos por argilominerais neo-formados e minerais da rocha em processo de alteração e apresentam texturas e estruturas da rocha parental preservadas (foliação, xistosidade, bandamento, fraturas e falhas). Este tipo de solo apresenta elevada heterogeneidade e anisotropia, com variações mineralógicas visíveis e coloração variegada. 


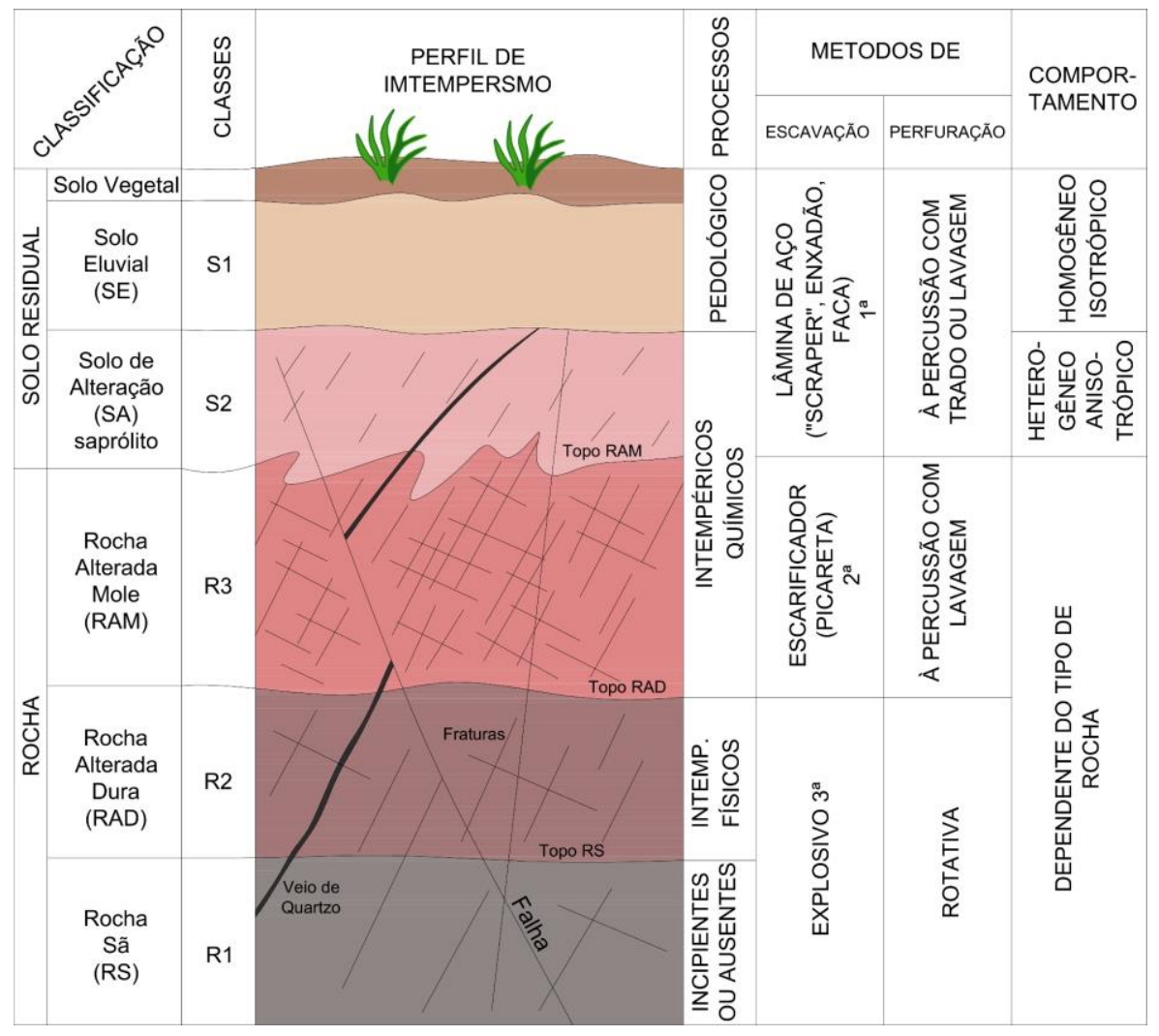

Figura 17: Perfil de alteração (Vaz, 1996)

\subsubsection{Resistência ao cisalhamento de solos residuais}

Segundo Brenner et al (1997), o entendimento da gênese de solos residuais e de suas propriedades é essencial para a compreensão dos fatores que afetam a resistência e a deformabilidade destes solos, sendo fundamental para a correta seleção de parâmetros em projetos civis. Além disso, o conhecimento das diferenças entre solos residuais e transportados é necessário para uma correta amostragem e interpretação de ensaios.

Os solos de alteração diferenciam-se dos solos transportados principalmente devido sua elevada heterogeneidade e sua complexa estrutura, herdadas da rocha parental. A estrutura de solos transportados (aluvionares, coluvionares, marinhos e eólicos) é definida fundamentalmente pelo seu modo de deposição e do histórico de tensões após sedimentação, devido isso, os solos transportados são caracterizados por apresentar camadas horizontais bastante homogêneas.

A Tabela 2, adaptada de Brenner et al (1997), sumariza os principais fatores que afetam os parâmetros de resistência de solos, comparando a ação destes fatores em solos residuais e transportados. 
Tabela 2. : Comparação de fatores que afetam a resistência de solos de alteração e transportados (adaptado de Brenner et al, 1997)

\begin{tabular}{|c|c|c|}
\hline $\begin{array}{l}\text { Fatores que afetam } \\
\text { a resistência de } \\
\text { solos }\end{array}$ & Efeito em solos de alteração & Efeito em solos transportados \\
\hline Histórico de tensões & Geralmente insignificante & $\begin{array}{l}\text { Muito importante: afeta o arranjo dos } \\
\text { grãos e índices de vazios inicial e é } \\
\text { responsável pelo efeito do } \\
\text { sobreadensamento de solos }\end{array}$ \\
\hline $\begin{array}{l}\text { Resistência dos } \\
\text { grãos }\end{array}$ & Muio variável: mineralogia muito variável & $\begin{array}{l}\text { Uniforme; apresenta grãos mais } \\
\text { resistentes, pois grãos frágeis são } \\
\text { eliminados durante transporte }\end{array}$ \\
\hline Cimentação & $\begin{array}{l}\text { Muito importante: ocorre por ligações e } \\
\text { cimentação herdadas da rocha parental. }\end{array}$ & Ocorre apenas em depósitos antigos \\
\hline $\begin{array}{l}\text { Arranjo dos grãos e } \\
\text { descontinuidades }\end{array}$ & $\begin{array}{l}\text { Herdado da rocha parental e de suas } \\
\text { estruturas (falhas, fraturas, bandamentos, } \\
\text { etc.) }\end{array}$ & $\begin{array}{l}\text { Desenvolvidos por ciclos deposicionais e } \\
\text { histórico de tensões. Pode haver falhas e } \\
\text { fraturas }\end{array}$ \\
\hline Anisotropia & $\begin{array}{l}\text { Herdado da rocha parental e de suas } \\
\text { estruturas (falhas, fraturas, bandamentos, } \\
\text { etc.) }\end{array}$ & $\begin{array}{l}\text { Desenvolvidos por ciclos deposicionais e } \\
\text { histórico de tensões }\end{array}$ \\
\hline Índice de vazios & $\begin{array}{l}\text { Depende do grau de decomposição da } \\
\text { rocha; é independente do histórico de } \\
\text { tensões }\end{array}$ & $\begin{array}{l}\text { Depende diretamente do histórico de } \\
\text { tensões }\end{array}$ \\
\hline
\end{tabular}

Como indicado na Tabela 2, a resistência de solos residuais é afetada por diversos fatores. Devido a elevada heterogeneidade e alta complexidade de estruturas típicas deste tipo de solo, Brenner et al (1997) afirma que a caracterização completa deste tipo de solo é de difícil obtenção e propõe duas maneiras de amostragem que proporcionam uma estimativa real dos parâmetros de resistência:

- realizar um grande número de ensaios em amostras de pequena escala;

- realizar um número adequado de ensaios em amostras de larga escala.

O autor sugere estes métodos de ensaio para que o maior número de estruturas presentes no solo seja considerado na estimativa dos parâmetros de resistência. Para tanto, a amostragem deve representar apropriadamente a variabilidade do solo. A escolha do método de ensaio depende dos equipamentos disponíveis para ensaio e do orçamento disponível para prospecção. 


\section{MÉTODOS}

Este capítulo tem o objetivo de apresentar a programação dos ensaios realizados e descrever as metodologias de execução adotadas. Serão descritos os métodos utilizados para a retirada de amostras em campo, moldagem de corpos de prova, execução de ensaios triaxiais convencionais e multi-estágio e o método de análise em microscópio eletrônico. Também será apresentada a descrição das prensas triaxiais utilizadas no programa experimental.

\subsection{Programação Experimental}

Este estudo tem o objetivo de avaliar a aplicação da técnica multi-estágio para a obtenção dos parâmetros de resistência e de deformabilidade em um solo residual jovem de elevada heterogeneidade, em amostras indeformadas e compactadas. Para tanto, foram realizados ensaios triaxiais convencionais e multi-estágio e os seus resultados foram comparados, de modo a avaliar o comportamento do solo em cada uma destas técnicas.

A Tabela 3 sumariza os ensaios especiais executados. Foram realizados ensaios triaxiais isotrópicos e anisotrópicos na condição não drenada em amostras indeformadas e compactadas. A programação inicial previa apenas a realização de ensaios anisotrópicos, porém, durante a etapa experimental foi necessária a mudança de equipamento triaxial e nova prensa não possuía o software que permite a execução de ensaios anisotrópicos, como era previsto.

Os ensaios em amostras compactadas (ensaios $\mathrm{A}$ e $\mathrm{B}$ ) foram realizadas com $\mathrm{O}$ objetivo de analisar o comportamento do solo ao longo de um ensaio multi-estágio em amostras homogêneas.

O ensaio $\mathrm{C}$ consiste em um ensaio multi-estágio do tipo CIU realizado com repetição da tensão de adensamento de $200 \mathrm{kPa}$ em uma amostra indeformada. Este tipo de ensaio foi idealizado por Kim e Ko (1979), que o executaram em uma rocha xistosa a fim de analisar a influência dos estágios iniciais e intermediários de cisalhamento na estimativa da resistência da rocha nos estágios finais (vide item 2.4.1). No presente estudo, o ensaio foi realizado com apenas uma fase de adensamento (até $200 \mathrm{kPa}$ ) e, em seguida, foram realizados três estágios de carregamento e descarregamento 
axial. No terceiro, e último estágio, o ensaio foi continuado até a ruptura do corpo de prova.

Os ensaios $D$ e $E$ consistem em ensaios convencionais do tipo CAU e CIU, respectivamente, realizados em amostras indeformadas. O ensaio $D$ foi realizado com as tensões de adensamento de 50,100, 200 e $300 \mathrm{kPa}$. Já o ensaio $E$ foi feito com tensões de 100, 200 e $300 \mathrm{kPa}$. Também foram realizados ensaios multi-estágios do tipo CAU e CIU em amostras indeformadas (ensaios F, G, H e I).

Tabela 3. Programa experimental - ensaios especiais realizados

\begin{tabular}{|c|c|c|c|c|}
\hline ID & $\begin{array}{l}\text { Tipo de } \\
\text { amostra }\end{array}$ & Bloco & $\begin{array}{l}\text { Tipo de } \\
\text { ensaio }\end{array}$ & Ensaio \\
\hline A & Compactada & Bloco B & Multi-estágio & $\begin{array}{l}\text { ME-CIU-100 kPa } \\
\text { ME-CIU-200 kPa } \\
\text { ME-CIU-300 kPa }\end{array}$ \\
\hline$B$ & Compactada & Bloco B & Convencional & $\begin{array}{l}\text { C-CIU-100 kPa } \\
\text { C-CIU-200 kPa } \\
\text { C-CIU-300 kPa }\end{array}$ \\
\hline C & Indeformada & Bloco A & Multi-estágio & $\begin{array}{l}\text { ME-CIU-200 kPa - I } \\
\text { ME-CIU-200 kPa - II } \\
\text { ME-CIU-200 kPa - III }\end{array}$ \\
\hline D & Indeformada & Bloco A & Convencional & $\begin{array}{l}\text { C-CAU-50 kPa } \\
\text { C-CAU-100 kPa } \\
\text { C-CAU-200 kPa } \\
\text { C-CAU-300 kPa }\end{array}$ \\
\hline$E$ & Indeformada & Bloco C & Convencional & $\begin{array}{l}\text { C-CIU-100kPa } \\
\text { C-CIU-200kPa } \\
\text { C-CIU-300kPa }\end{array}$ \\
\hline$F$ & Indeformada & Bloco A & Multi-estágio & $\begin{array}{l}\text { ME-CAU-50 kPa } \\
\text { ME-CAU-100 kPa } \\
\text { ME-CAU-200 kPa }\end{array}$ \\
\hline G & Indeformada & Bloco A & Multi-estágio & $\begin{array}{l}\text { ME-CAU-50 kPa } \\
\text { ME-CAU-100 kPa }\end{array}$ \\
\hline $\mathrm{H}$ & Indeformada & Bloco A & Multi-estágio & $\begin{array}{l}\text { ME-CIU-50 kPa } \\
\text { ME-CIU-100 kPa } \\
\text { ME-CIU-200 kPa }\end{array}$ \\
\hline I & Indeformada & Bloco C & Multi-estágio & $\begin{array}{l}\text { ME-CIU-100 kPa } \\
\text { ME-CIU-200 kPa } \\
\text { ME-CIU-300 kPa }\end{array}$ \\
\hline
\end{tabular}

O ensaio $\mathrm{G}$ foi realizado com tensões de 50 e $100 \mathrm{kPa}$ e os estágios de cisalhamento foram interrompidos no limiar da ruptura. Após as fases de cisalhamento, a amostra foi adensada até $200 \mathrm{kPa}$ e o corpo de prova foi retirado da câmara para a realização 
de análises microestruturais em MEV. O objetivo destas análises é avaliar a influência dos estágios de cisalhamento axial iniciais na estrutura da amostra e verificar se há formação de plano de ruptura nestes estágios.

As amostras utilizadas nos ensaios de $50 \mathrm{kPa}$ e $100 \mathrm{kPa}$ do ensaio $D$ também foram analisadas em MEV, a fim de se comparar a estrutura das amostras após a ruptura.

\subsection{Retirada de Amostras e Armazenamento}

A coleta de amostras ocorreu em um talude localizado no Campo Experimental do Laboratório de Mecânica de Solos da Escola Politécnica, no campus Butantã da Universidade de São Paulo. Foi realizada extração de amostras deformadas, utilizadas nos ensaios de caracterização, e de três blocos indeformados, para a realização dos ensaios especiais.

Para a coleta do bloco indeformado, primeiramente foi efetuada uma limpeza do terreno, com a retirada de detritos vegetais e materiais estranhos. Posteriormente, 0 solo foi escavado, com uso de pás, facas e espátulas, de modo que fosse moldada uma amostra cúbica, com arestas de aproximadamente $25 \mathrm{~cm}$, como ilustrado na Figura 18. A moldagem foi realizada cautelosamente, para que a amostra fosse minimamente perturbada.

Após a moldagem da amostra, ainda sem a retirada de sua base, a amostra foi envolvida em uma camada de papel alumínio e, em seguida, por uma camada de tecido. Posteriormente, uma caixa de madeira foi encaixada na amostra e esta foi preenchida com parafina. Logo após, a base da amostra foi retirada do talude. Em seguida, a caixa foi selada e transportada para o laboratório. 

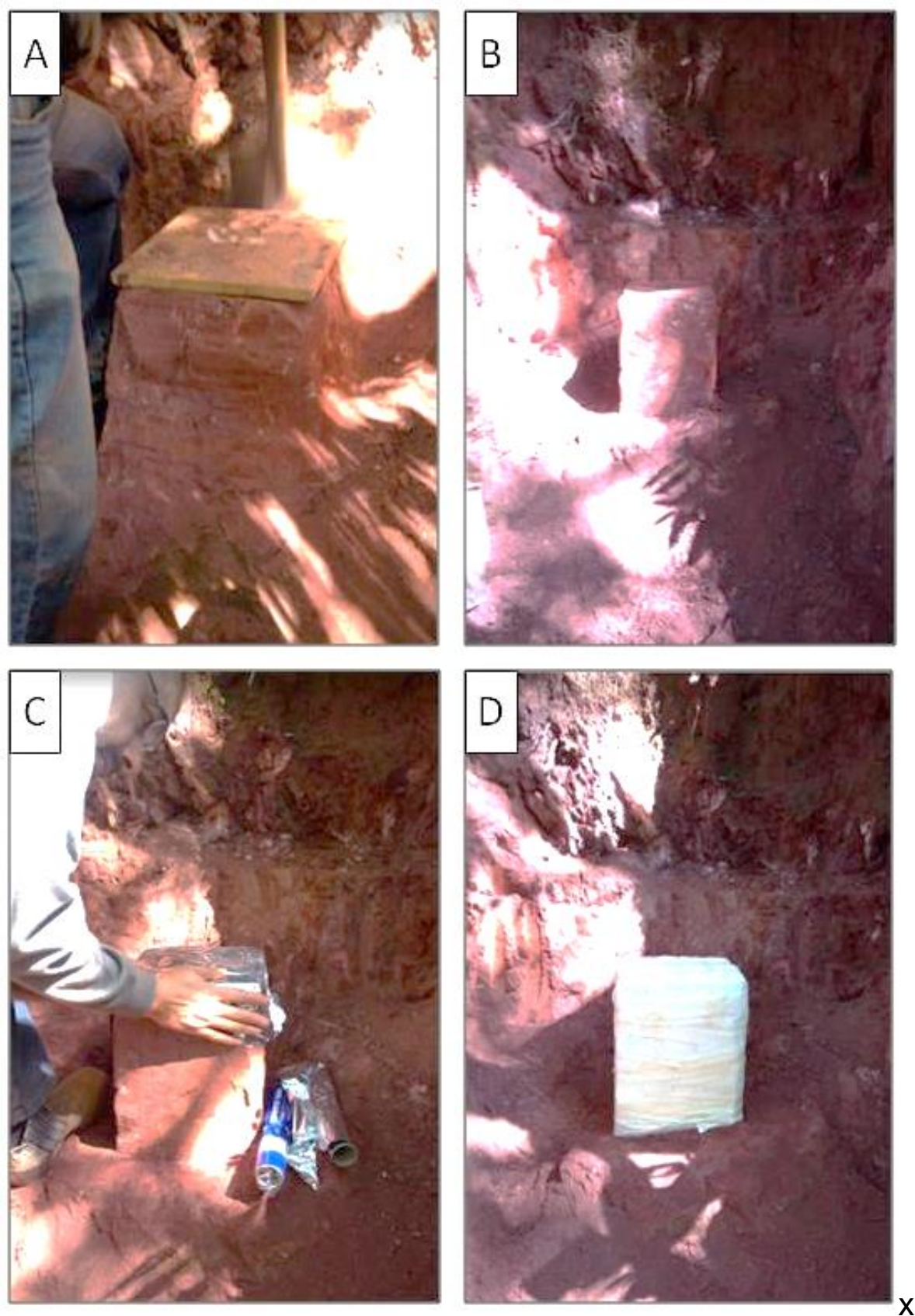

Figura 18. Coleta de bloco indeformado. (A) moldagem da amostra; (B) amostra moldada em formato cúbico; (C) amostra sendo coberta por papel laminado; e (D) amostra envolvida por papel laminado e tecido.

Em laboratório, o bloco foi removido da caixa, etiquetado e armazenado em local com pouca variação de temperatura, para evitar perturbações e variações da umidade. As amostras deformadas, coletadas do solo retirado durante a moldagem do bloco, foram levadas para secagem e foram preparadas para os ensaios de caracterização de acordo com a norma NBR-6457/1984 (ABNT, 1984). 


\subsection{Ensaios de Caracterização}

Ensaios de caracterização foram realizados para cada um dos blocos indeformados coletados. Foram executados os seguintes ensaios: granulometria, limite de liquidez, limite de plasticidade e densidade dos grãos. Estes ensaios foram realizados de acordo com as seguintes normas:

- Granulometria: NBR-7181/1984

- Densidade dos grãos: NBR-6508/1984

- Limite de liquidez: NBR-6459/1984

- Limite de plasticidade: NBR-7180/1984

No Bloco $C$ também foi realizado ensaio de compactação de Proctor normal, com o objetivo de determinar parâmetros para a moldagem dos corpos de prova utilizados nos ensaios A e B. O ensaio foi realizado de acordo com a norma NBR-7182/1986 com energia normal e reuso do material.

\subsection{Ensaios Especiais}

Nos itens a seguir serão descritos os procedimentos utilizados na moldagem dos corpos de prova e na execução dos ensaios triaxiais convencionais e multi-estágios. No item 3.4.1 será apresentada uma descrição dos equipamentos triaxiais utilizados.

\subsubsection{Descrição das prensas triaxiais utilizadas}

$\mathrm{Na}$ etapa experimental foram utilizadas as prensas triaxiais presentes no laboratório de mecânica de solos da USP (LMS-USP) e a prensa do laboratório de geotecnia da empresa Egis.

A prensa do LMS-USP é do tipo Bishop \& Wesley (1975), ilustrada na Figura.19. Esta prensa realiza a transmissão da pressão confinante e da contrapressão utilizando reguladores de pressão com interface entre água e ar. A tensão axial é aplicada pela elevação da base da prensa e a pressão transmitida é medida em uma célula de carga, instalada no topo da câmara (e.g. Gúzman,2014). 


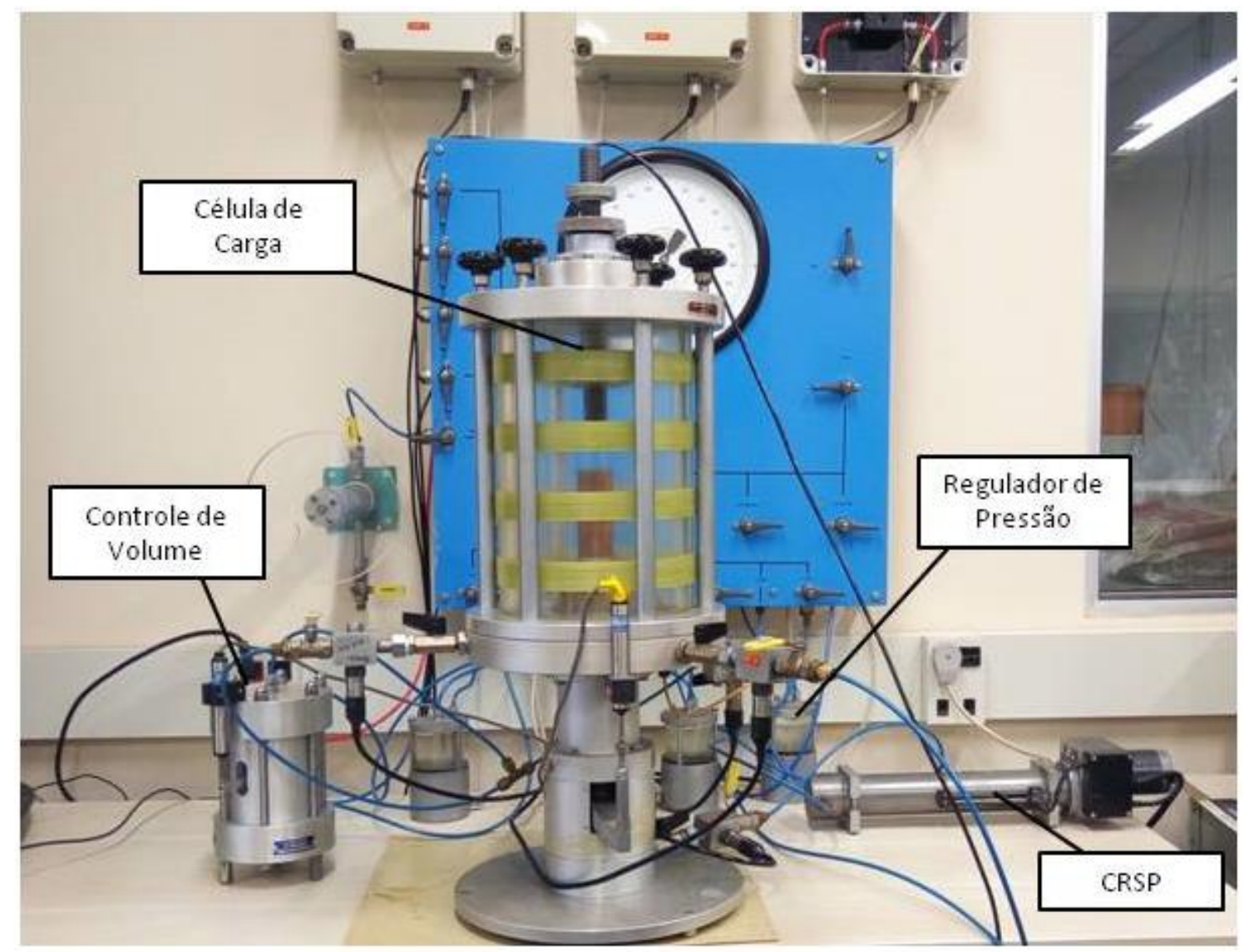

Figura.19. Prensa triaxial tipo Bishop e Wesley

As leituras das tensões aplicadas são efetuadas através da célula de carga e de transdutores de pressão, que são conectados a um sistema de aquisição de dados, medindo até $100 \mathrm{mv}$ com resolução de $0,6 \mu \mathrm{v}$.

Os dados obtidos são transmitidos para o computador e são gerenciados pelo software Triax 5.1.8 ${ }^{\circledR}$, desenvolvido pela equipe de sistemas geotécnicos da Universidade de Durham.

O equipamento utilizado na empresa Egis Engenharia é o AutoTriax®, da empresa inglesa Wykeham Farrance, que realiza ensaios triaxiais com deformação controlada (Figura 20). 


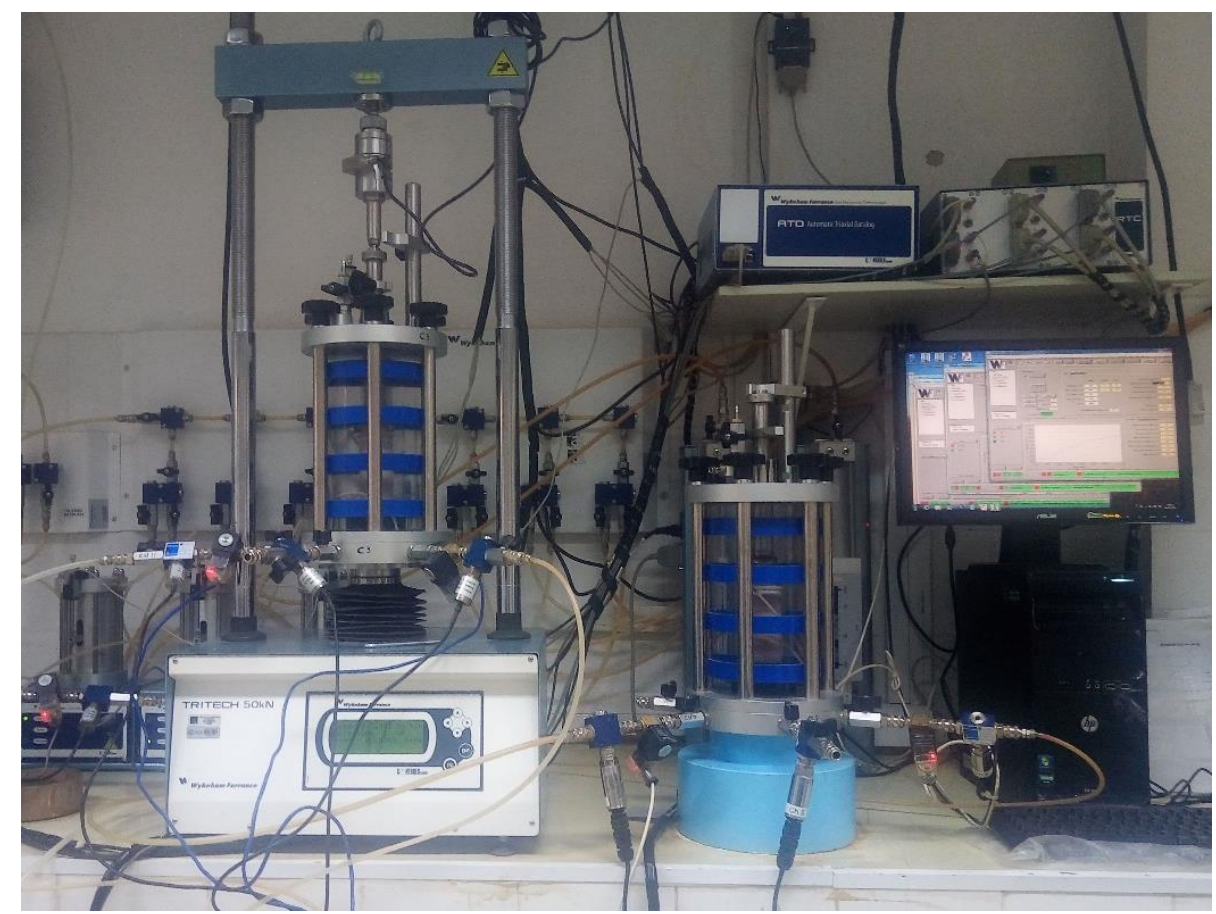

Figura 20. Prensa triaxial da Wykeham Farrance

\subsubsection{Moldagem e compactação dos corpos de prova}

Foram utilizados dois tipos de corpos de prova: corpos de prova indeformados e corpos de prova obtidos por compactação estática.

Os corpos de prova indeformados foram obtidos através de talha manual das amostras, com uso de serras, facas e estiletes. Os corpos de prova utilizados em ensaios triaxiais foram moldados em formato cilíndrico, com altura de $80 \mathrm{~mm}$ e diâmetro de $38 \mathrm{~mm}$. A moldagem foi realizada com auxílio de um berço modelador para regularizar as extremidades e determinar a altura do corpo de prova. O formato cilíndrico foi obtido com auxílio de um torno.

As amostras amolgadas foram obtidas a partir de compactação estática. Os corpos de prova foram compactados de modo a atingir o índice de vazios natural médio do solo. A compactação foi realizada em cinco etapas, em um molde cilíndrico, de $38 \mathrm{~mm}$ de diâmetro e $80 \mathrm{~mm}$ de altura.

\subsubsection{Método de execução dos ensaios triaxiais convencionais}

A execução do ensaio de cisalhamento triaxial convencional é realizada nas seguintes etapas: montagem do corpo de prova, saturação, adensamento e cisalhamento. Nos itens a seguir serão explicitadas as metodologias de execução adotadas para cada uma dessas etapas. 


\subsubsection{Montagem do corpo de prova}

Para a realização do ensaio, o corpo de prova é colocado sobre o pedestal da prensa triaxial, em contato com um papel filtro e uma pedra porosa, em seu topo e base. Em seguida, o corpo de prova é envolvido com uma membrana impermeável, permitindo drenagem apenas em suas extremidades, no topa e na base. No topo do corpo de prova foi realizada as medidas de poro-pressão. Posteriormente, a câmara é fechada e é totalmente preenchida com água.

\subsubsection{Etapa de saturação}

O processo de saturação dos corpos de prova é realizado em duas fases. Primeiramente, é realizada a umidificação por aspersão de água. Posteriormente, é realizada saturação por incremento de contrapressões na câmara triaxial, mantendo a tensão confinante em $10 \mathrm{kPa}$.

Este último procedimento, descrito por Bishop e Henkel (1962), consiste no aumento de poro-pressões $(u)$ com incremento simultâneo da pressão confinante $\left(\sigma_{3}\right)$, dessa forma, a tensão efetiva é mantida fixa. O aumento das contrapressões resulta na diminuição do volume de ar por compressão e dissolução na água.

Para os ensaios realizados no LMS-USP, determinou-se que a saturação deve ocorrer com elevação da contrapressão até $490 \mathrm{kPa}$, mantendo fixa a tensão efetiva em 10 $\mathrm{kPa}$. O incremento de pressões é realizado em uma taxa de $40 \mathrm{kPa} / \mathrm{hora}$, desse modo, o tempo de saturação de um corpo de prova é de aproximadamente 12 horas.

Para garantir que o corpo de prova se apresente na condição saturada após a elevação da contrapressão, mede-se o parâmetro B. Para tanto, aplica-se uma tensão confinante de $50 \mathrm{kPa}$, com drenagens fechadas no topo e na base do corpo de prova. $\mathrm{Na}$ condição saturada, com o incremento rápido da tensão confinante, ocorre aumento da contrapressão, em igual proporção.

O índice B é calculado pela seguinte expressão:

$$
B=\frac{u f-u i}{\sigma 3 f-\sigma 3 i}
$$

Onde, $\sigma_{3 i}$ e ui representam a tensão confinante e a poro-pressão na condição inicial, respectivamente, e $\sigma_{3 \mathfrak{f}}$ e uf simbolizam a tensão confinante e a contrapressão após o 
incremento de pressão. Considera-se que o solo se encontra na condição saturada com valores de $B$ superiores a 0.95 .

Em ensaios realizados com o solo estudado verificou-se que a saturação efetuada apenas por incremento da contrapressão resulta em valores de $\bar{B}$ insatisfatórios, entre 0.93 e 0.94. Por isso, adotou-se também a técnica de saturação por aspersão. Neste caso, o parâmetro $B$, medido após a realização da saturação por aspersão e por contrapressão, resultou em um valor de $\overline{\mathrm{B}}$ próximo de 0.98 .

Black e Lee (1973) demonstram que muitos solos podem não chegar à saturação total $(B=1)$. Muitos fatores podem dificultar a saturação completa da amostra, como por exemplo, a rigidez do solo e a necessidade de aplicação de contrapressões extremamente elevadas, dificultadas pelas condições técnicas do laboratório.

Para os ensaios realizados na Egis Engenharia o equipamento permite o cálculo de $B$ a cada incremento de tensões confinantes e poro-pressões. Neste caso, a pressão efetiva foi mantida em $15 \mathrm{kPa}$ e a etapa de saturação foi continuada até a obtenção de valores de $B$ aceitáveis, não havendo limitação das tensões totais máximas.

\subsubsection{Etapa de adensamento}

Após a saturação é realizada a etapa de adensamento, que consiste no lento incremento da tensão efetiva. Nos ensaios triaxiais convencionais, cada corpo de prova é adensado com diferentes tensões efetivas. Nesta pesquisa, as tensões de adensamento efetivas adotadas foram: 50, 100, 200 e $300 \mathrm{kPa}$.

Nos ensaios realizados no LMS foi adotado o adensamento anisotrópico, que permite melhor caracterização dos módulos de deformabilidade durante o cisalhamento. Nos ensaios anisotrópicos, os corpos de prova foram adensados com relação entre tensão confinante e tensão axial igual a 0,7. O equipamento utilizado na Egis Engenharia não permite a execução de adensamento anisotrópico.

O processo de adensamento foi realizado permitindo drenagem na base do corpo de prova e com drenagem fechada no topo, para ter controle de eventuais desenvolvimentos de contrapressões. 


\subsubsection{Etapa de cisalhamento}

A etapa de cisalhamento, nos ensaios triaxiais convencionais, consiste no incremento da tensão axial continuado até o rompimento do corpo de prova. Nos ensaios realizados, o cisalhamento foi realizado com deformação controlada, com taxa de deformação de $0,03 \%$ por minuto.

Foram realizados apenas ensaios na condição não drenada e, portanto, a drenagem do topo e da base do corpo de prova não foi permitida durante a fase de cisalhamento. Dessa forma, não ocorre alteração de volume durante o carregamento axial.

\subsubsection{Método de execução dos ensaios triaxiais multi-estágios}

No ensaio triaxial multi-estágio são realizados três estágios de cisalhamento em um único corpo de prova, com diferentes tensões de adensamento, sem que ocorra total mobilização da resistência do solo nos estágios intermediários. A etapa de saturação e as etapas de adensamento foram realizadas com a mesma metodologia adotada nos ensaios convencionais, descritas nos itens 3.4.3.2 e 3.4.3.3.

As etapas de cisalhamento foram realizadas com deformação controlada e na condição não drenada, de forma análoga aos ensaios convencionais. Porém, neste caso, o carregamento axial é continuado até atingir o critério de paralisação definido, ou seja, o cisalhamento é interrompido assim que se constate tendência de estabilização da tensão desviadora (próximo de $d q / d \varepsilon=0$ ). O critério de paralisação utilizado foi utilizado por De Beer (1950) e está descrito no item 4.3.1.

Durante o carregamento, o controle da deformação e da tensão axial aplicada é realizado pelo software Triax 5.1.8 ${ }^{\circledR}$, desenvolvido na Universidade de Durham (UK). Após a paralisação da fase de cisalhamento, a tensão axial é retirada. Nos ensaios isotrópicos, a carga axial foi totalmente retirada. Já nos ensaios anisotrópicos, a carga axial foi parcialmente retirada, mantendo a tensão desviadora na condição anisotrópica de adensamento, como ilustrado na trajetória de tensões apresentadas na Figura 21. Após o descarregamento, as válvulas de drenagem foram abertas, permitindo a dissipação das poro-pressões geradas na etapa de cisalhamento. Em seguida, uma nova etapa de adensamento é iniciada. O processo é repetido para as três etapas de cisalhamento. No último estágio, o carregamento é continuado após o rompimento do corpo de prova. 
Para exemplificar, a Figura 21 apresenta as trajetórias de tensões resultante do ensaio F. Na figura, a linha tracejada preta indica a evolução do adensamento anisotrópico experimental. As linhas em vermelho mostram o descarregamento axial e as linhas amarelas mostram o aumento da tensão efetiva gerado pela dissipação das poropressões, após abertura dos canais de drenagem. Nota-se que após a dissipação da poro-pressão, o estado de tensões retorna exatamente ao ponto de início da etapa de cisalhamento anterior.

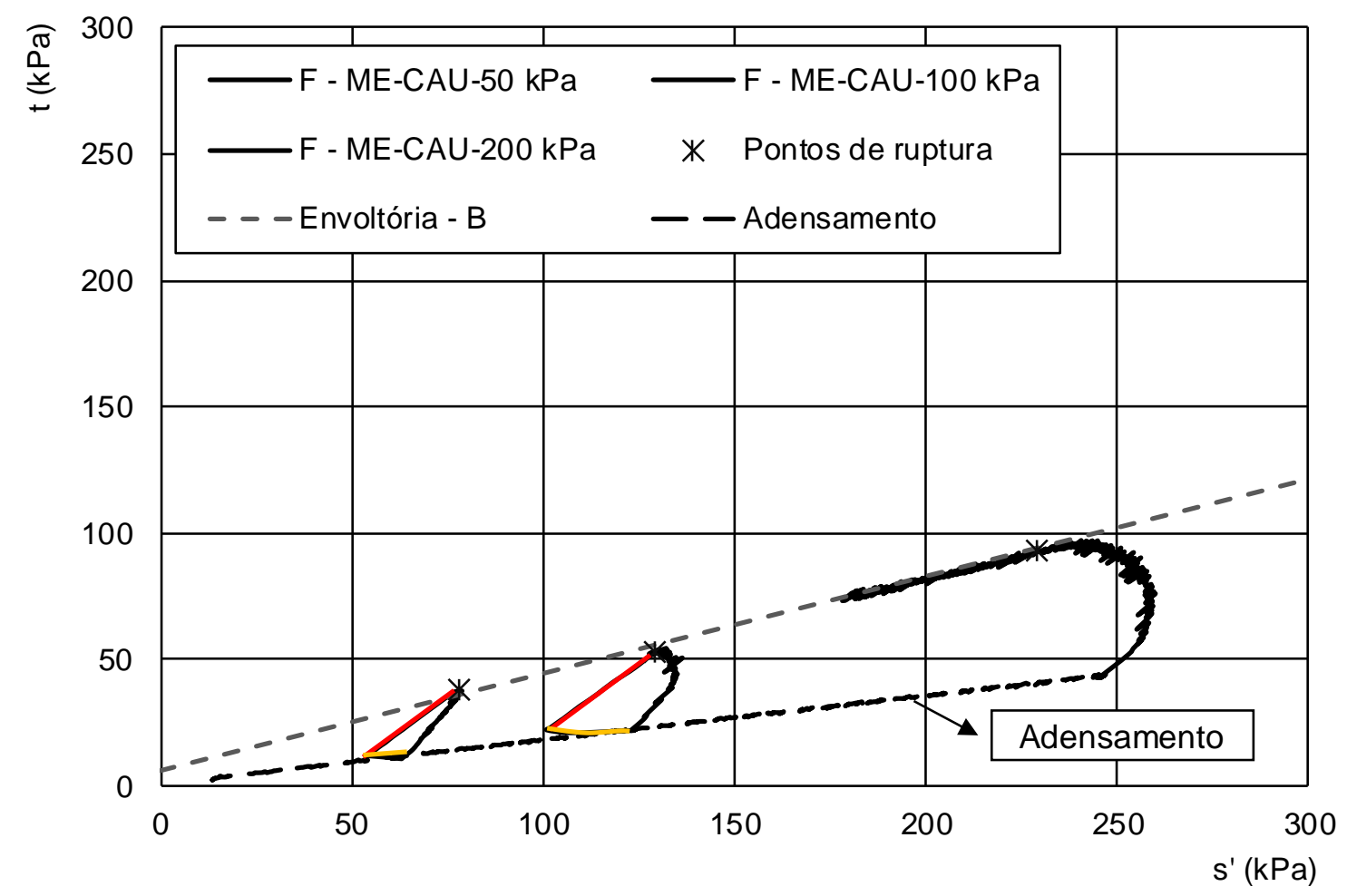

Figura 21. Trajetória de tensões resultante do ensaio $F$, indicando as etapas de adensamento (linha tracejada em preto), de cisalhamento (curvas em preto), descarregamento axial (em vermelho) e dissipação das poro-pressões (em amarelo).

\subsection{Análises em Microscópio Eletrônico de Varredura (MEV)}

Com o objetivo de avaliar a microestrutura dos corpos de prova após as fases iniciais de cisalhamento no ensaio multi-estágio, realizou-se um ensaio múltiplo com tensões de adensamento de 50 e $100 \mathrm{kPa}$, com paralisação do carregamento axial no limiar da ruptura (Ensaio G, da Tabela 3). Em seguida, o corpo de prova foi adensado até $200 \mathrm{kPa}$ e, neste ponto, o ensaio foi finalizado, sem a execução do último estágio de cisalhamento. Esta amostra foi retirada e, posteriormente, foi analisada no Microscópio Eletrônico de Varredura (MEV). A trajetória de tensões resultante deste ensaio (ensaio G) está apresentada na figura 24, onde está ilustrada o ponto de finalização do ensaio. 


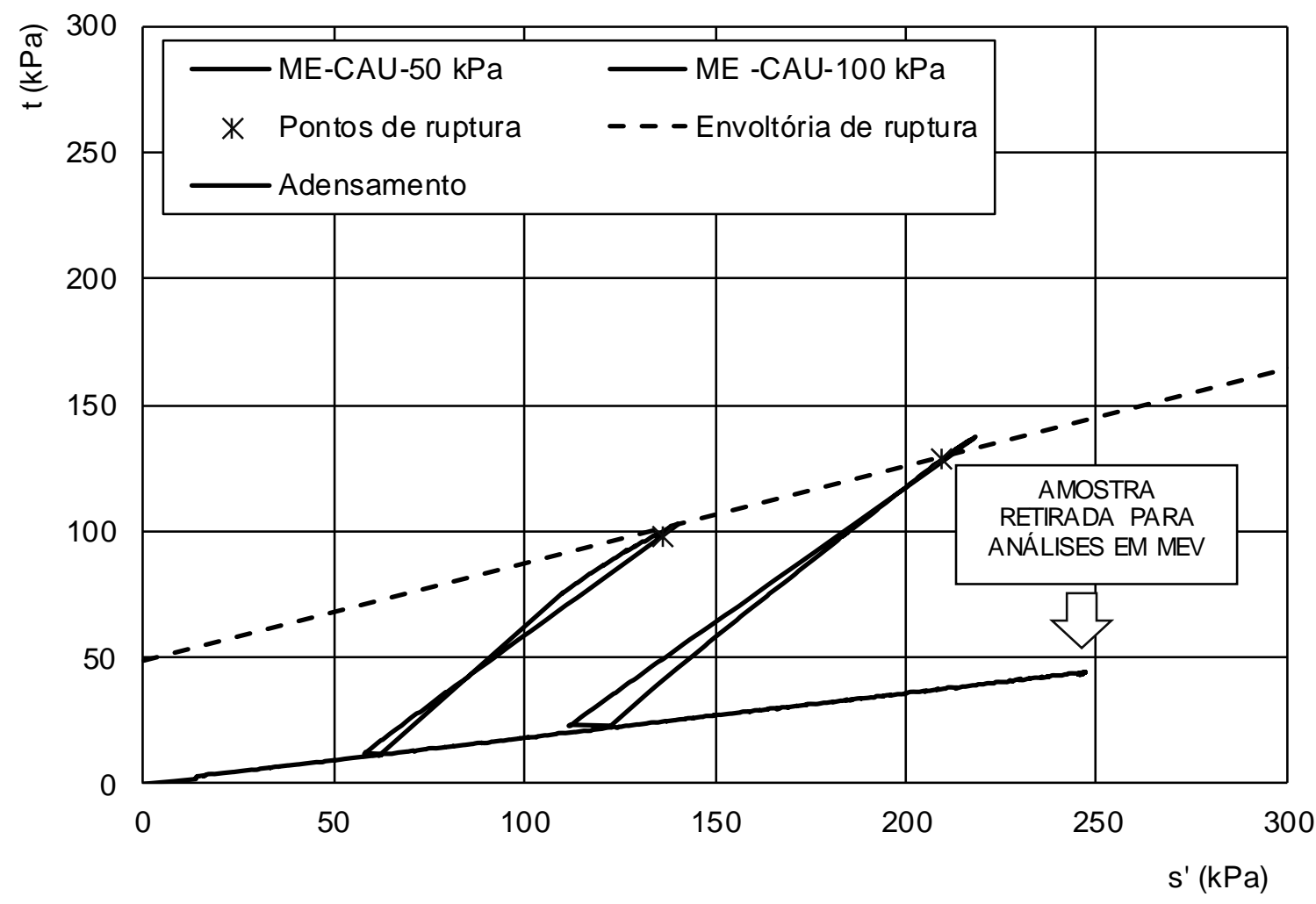

Figura 22. Trajetórias de tensões resultante do ensaio G, indicando ponto de finalização do ensaio e retirada da amostra para análises em MEV

Para comparar a estrutura do corpo de prova do ensaio $G$ com corpos de provas cisalhados em ensaios convencionais, as amostras utilizadas para os ensaios de 50 $\mathrm{kPa}$ e $100 \mathrm{kPa}$ do ensaio $\mathrm{D}$ também foram analisadas em MEV. A Figura 23 apresenta as curvas de tensão-deformação do ensaio $\mathrm{G}$ e dos ensaios de 50 e $100 \mathrm{kPa}$ do ensaio $\mathrm{D}$, indicando os níveis de deformação máximo que os corpos de prova analisadas foram submetidas.

Os corpos de prova utilizados nos ensaios de 50 e $100 \mathrm{kPa}$ do ensaio $\mathrm{D}$ sofreram deformações axiais de $6,67 \%$ e 9,49\%, respectivamente. O corpo de prova do ensaio multi-estágio G sofreu deformação de 1,25\%. 


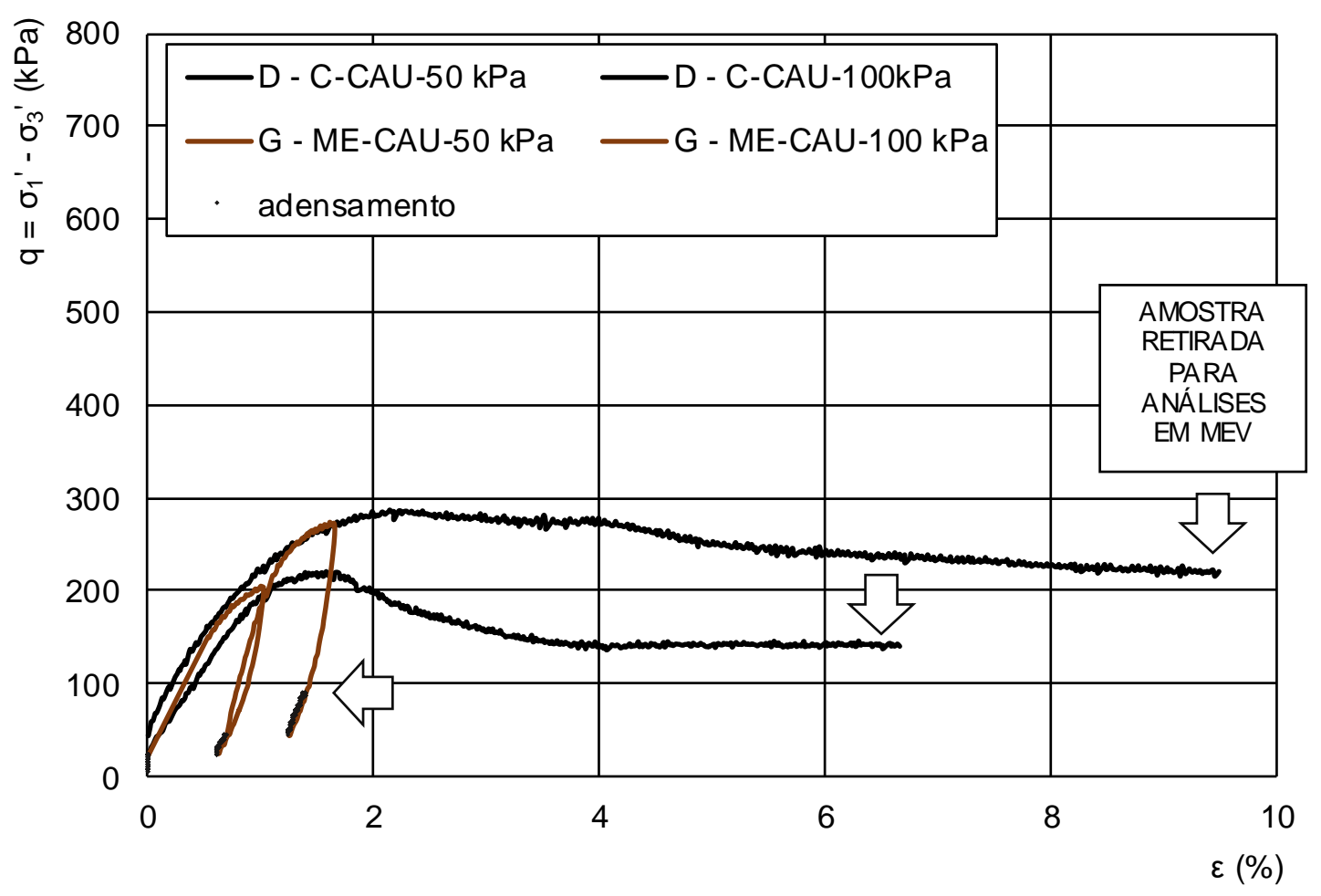

Figura 23. Curvas de tensão-deformação do ensaio G e dos ensaios de 50 e $100 \mathrm{kPa}$ do ensaio D, indicando a máxima deformação a qual as amostras analisadas em MEV foram submetidas

\subsubsection{Preparação dos corpos de prova}

Para possibilitar o corte dos corpos de prova na posição de interesse sem danificar a estrutura da amostra, os corpos de prova foram impregnados com a resina EpoxiGlass $\AA^{\circledR}$. Para tanto, o corpo de prova foi submergido em uma solução de resina e endurecedor. A resina infiltra no corpo de corpo por capilaridade e após sua consolidação o corte do corpo de prova será viabilizado.

Resinas tipo epoxi são hidrofóbicas, por isso anteriormente à impregnação, os corpos de prova foram levados para secagem em estufa. Diversos autores (Dress, 1977, Gillot, 1976, Camuti e McGuire, 1999, dentre outros) salientam que a secagem de solos em estufa causa alterações volumétricas na amostra, devido contrações causadas por sucção induzida e por presença de argilominerais expansivos. Esta contração pode gerar trincas e perturbações na estrutura da amostra, afetando as análises microscópicas.

Uma amostra do solo estudado foi levada para estufa para observação do grau de contração do corpo de prova. A amostra foi colocada em estufa com temperatura constante de $40^{\circ} \mathrm{C}$ por aproximadamente 12 horas e, posteriormente, submetida à temperatura de $105^{\circ} \mathrm{C}$ por mais 12 horas. Não foi observada incidência de trincas e 0 
grau de contração axial foi próximo de 4\%. Dessa forma, considera-se que as perturbações causadas por secagem não causam influência significativa na estrutura das amostras e não serão prejudiciais às análises microscópicas.

Após a impregnação os corpos de prova foram serrados verticalmente, perpendicularmente aos planos de ruptura gerados. O corpo de prova submetido ao ensaio multi-estágio foi cortado em duas direções. As faces foram polidas, para evitar interferência das marcas de serra nas análises microscópicas.

\subsubsection{Análise e tratamento das imagens}

Após a etapa de preparação das amostras, foram realizadas as análises microscópicas no equipamento de MEV pertencente ao LCT-USP (Laboratório de Caracterização Tecnológica). As amostras de $50 \mathrm{kPa}$ do ensaio D e o corte transversal do ensaio do ensaio $G$ foram analisados sem recobrimento e na condição de baixo vácuo. O restante das amostras foi revestido por material carbonático, para geração de corrente elétrica, e foram analisadas na condição de alto vácuo. Foram geradas imagens de backscattering (elétrons retrabalhados), com magnetrometria entre 100x e 6500x.

Nas amostras com presença de zonas de cisalhamento, foram realizadas imagens ao longo de toda a ruptura, permitindo uma análise microestrutural de toda a zona de cisalhamento e interpretações cinemáticas. Estas imagens foram realizadas magnetometria de 100x e aceleração de elétrons de 10,00 kV, permitindo uma análise textural satisfatória e baixas relações topográficas. As imagens geradas foram unidas e apresentadas em forma de foto-mosaico (anexo A). Os foto-mosaicos foram construídos utilizando o software AutoCAD.

Também foram realizadas imagens de maior de detalhe, com magnetometria de até $6500 x$. Estas imagens foram geradas com menor energia $(5,00 \mathrm{kV})$, permitindo boas relações topográficas superficiais. 


\section{CARACTERIZAÇÃO GEOLÓGICO-GEOTÉCNICA DO SOLO UTILIZADO}

Este capítulo apresenta os aspectos geológicos regionais do local de coleta de amostras e a descrição do solo utilizado. Também são apresentados resultados dos ensaios de caracterização realizados e uma comparação destes resultados com dados obtidos na literatura.

\subsection{Local de Amostragem}

O solo utilizado nesta pesquisa foi coletado no campo experimental de geotecnia do Laboratório de Mecânica de Solos da Escola Politécnica (LMS-USP), situado no campus Butantã da Universidade de São Paulo, na zona oeste do município de São Paulo, Brasil. A Figura 24 traz um mapa esquemático do local de coleta da amostra.

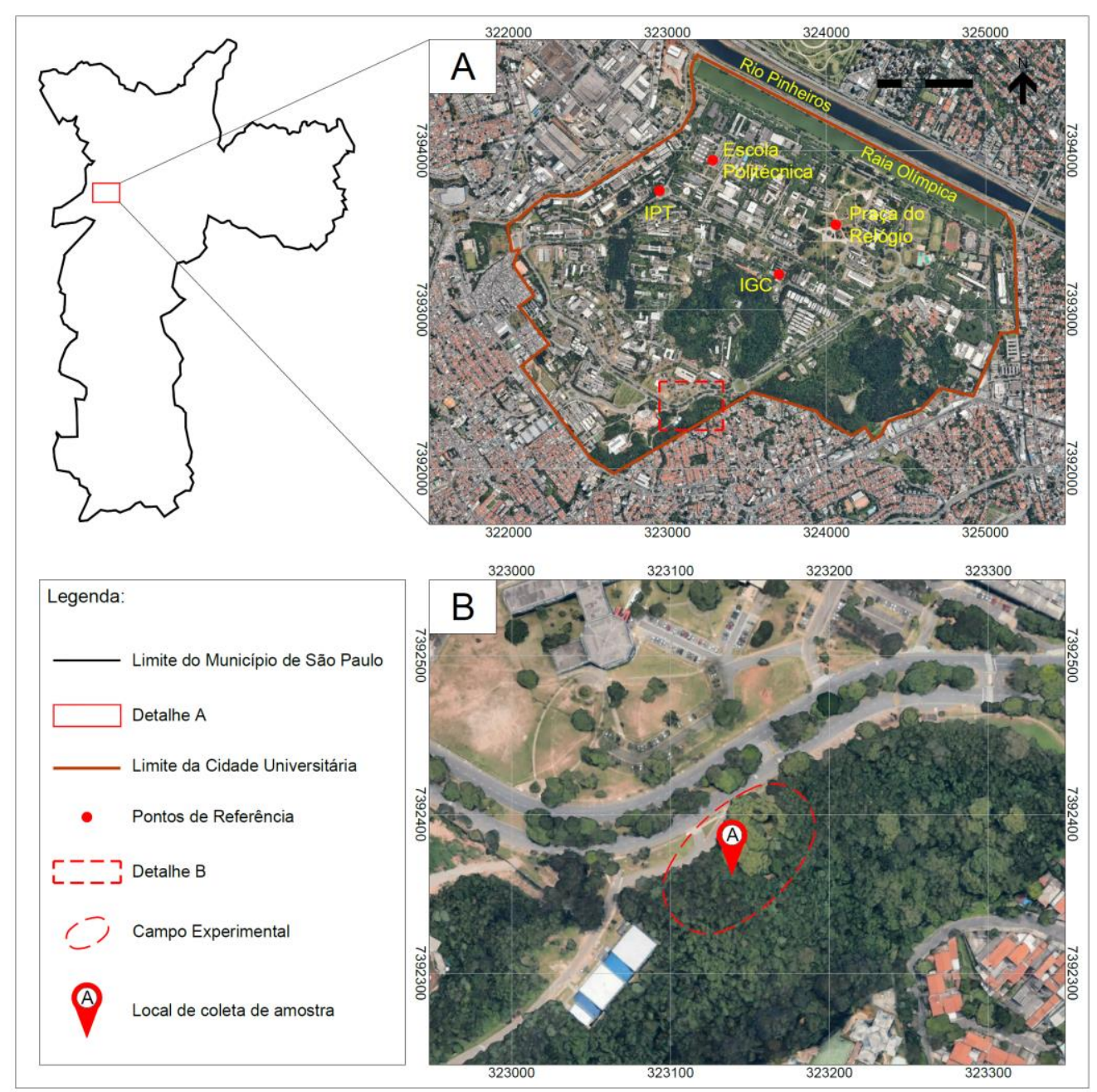

Figura 24. Localização da área de estudo. (A) está indicado os limites da cidade universitária e em (B) há a demarcação do campo experimental (fonte: Google Earth ${ }^{\circledR}, 2017$ ) 


\subsection{Caracterização Geológica Regional}

O município de São Paulo está localizado no Platô Paulistano e é constituído por três compartimentos geológicos principais: embasamento cristalino Pré-Cambriano, sedimentos Paleógenos e Neógenos da Bacia de São Paulo e por coberturas aluvionares quaternárias, em ordem estratigráfica (ABEF, 1989).

A Bacia Sedimentar de São Paulo apresenta-se como uma faixa alongada entre os municípios de Arujá e Embu-Guaçu, com área próxima de 1000 km² (Gurgueira, 2013). Esta bacia está associada ao Rift Continental do Sudeste do Brasil, relacionada à tectônica distensiva Neógena e Paleógena, que foi responsável pela formação de diversas bacias com direção NE-SW, paralelas a linha de costa brasileira, como a Bacia de Itaboraí, Bacia de Resende, Bacia de São Paulo, Bacia de Taubaté, entre outras (Monteiro et al, 2012). De modo geral, a Bacia de São Paulo é preenchida por sedimentos fluviais e lacustres e é constituída principalmente por argilitos, lamitos arenosos e conglomerados.

O embasamento da Bacia de São Paulo é composto por rochas do Cinturão Ribeira, que pertencem ao Sistema Orogênico da Mantiqueira. Este sistema é proveniente da Orogenia Brasiliana, que originou o paleocontinente Gondwana durante o Neoproterozóico (Monteiro et al, 2012). No município de São Paulo, o Cinturão Ribeira é constituído por rochas ígneas e metamórficas pertencentes, majoritariamente, ao Complexo Embu e aos Grupos São Roque, Serra de Itaberaba e corpos graníticos intrusivos.

O Complexo Embu, onde aloja-se a área de estudo, está localizado na porção centrosul do Município de São Paulo e é representado por uma faixa de afloramentos com direção NE-SW. É constituído por xistos, filitos, migmatitos, gnaisses e, secundariamente, por lentes de anfibolitos e rochas calciossilicaticas (Monteiro et al, 2012).

\subsection{Caracterização Geológica Local}

O subsolo do campo experimental é constituído por solo residual jovem, proveniente da decomposição de rochas migmatíticas pertencentes ao Complexo Embu (ABEF, 1989). O local de coleta de amostras consiste em um talude pré-escavado de aproximadamente 4 metros de altura, como ilustrado na figura 27. Foi realizada a coleta de três blocos indeformados (blocos A, B e C) para a realização de ensaios 
especiais e amostras deformadas para a execução de ensaios de caracterização e ensaios em solo compactado.

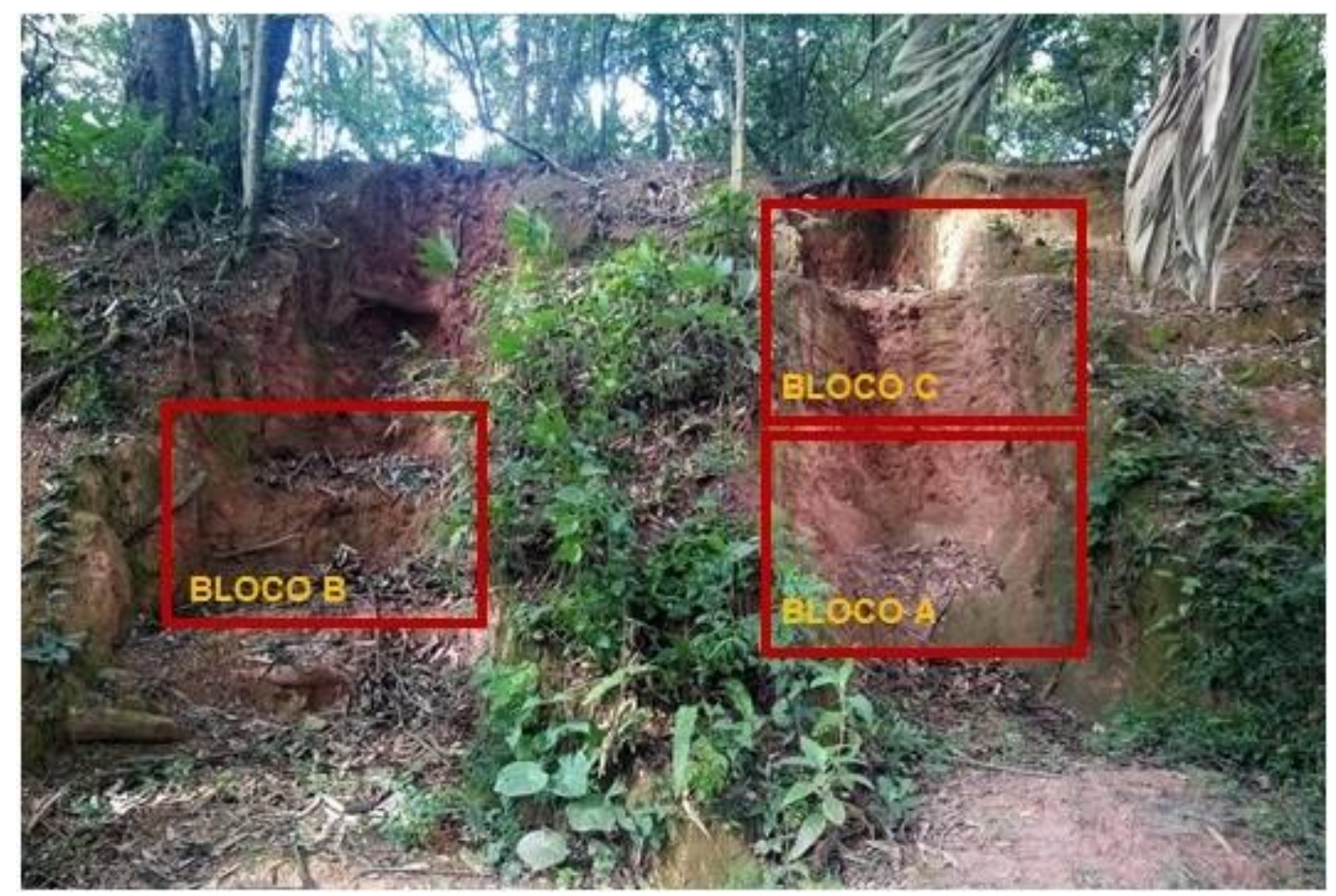

Figura 25. Locais de retirada de blocos indeformados (blocos A, B e C) em talude pré-escavado no campo experimental de geotecnia do LMS-USP

O solo analisado apresenta composição bastante heterogênea. É constituído, em média, por silte arenoso com pedregulho, de coloração marrom avermelhado e com estrutura foliada preservada. A foliação apresenta direção leste - oeste com mergulho sub-vertical $\left(80-85^{\circ} \mathrm{S}\right)$. Porém, em alguns locais ocorrem mudanças bruscas de atitude. Estas mudanças são geradas, provavelmente, por processos de fusão da rocha-mãe.

É cortado por bolsões alongados, de coloração branca, de dimensões variadas (10 $\mathrm{cm}$ a $1 \mathrm{~m}$ ), constituídos por areia fina a média e compostos, primordialmente, por caolinita e grãos de quartzo (Figura 26a). Estes bolsões ocorrem, em sua maioria, concordantes com a foliação. Provavelmente, estes bolsões correspondem a fração leucossomática da rocha-mãe, resultado da fusão parcial do gnaisse pré-existente. Em alguns locais ocorrem veios de quartzo, de espessura entre 3 a $5 \mathrm{~cm}$, associados a estes bolsões (Figura 26b).

Também foram observadas fraturas irregulares, que ocorrem comumente preenchidas por material de coloração marrom, de elevada dureza, como ilustrado na Figura 26c. 
ABEF (1989) classificou este material como uma associação de argilominerais com óxidos e hidróxidos e ferro.

Em menor escala, ocorrem bolsões, em geral de formato esférico, de dimensões entre 2 a 4 cm de diâmetro, constituídos por um material silto-argiloso, de coloração marrom escura e de elevada porosidade, como mostra a Figura 26c.
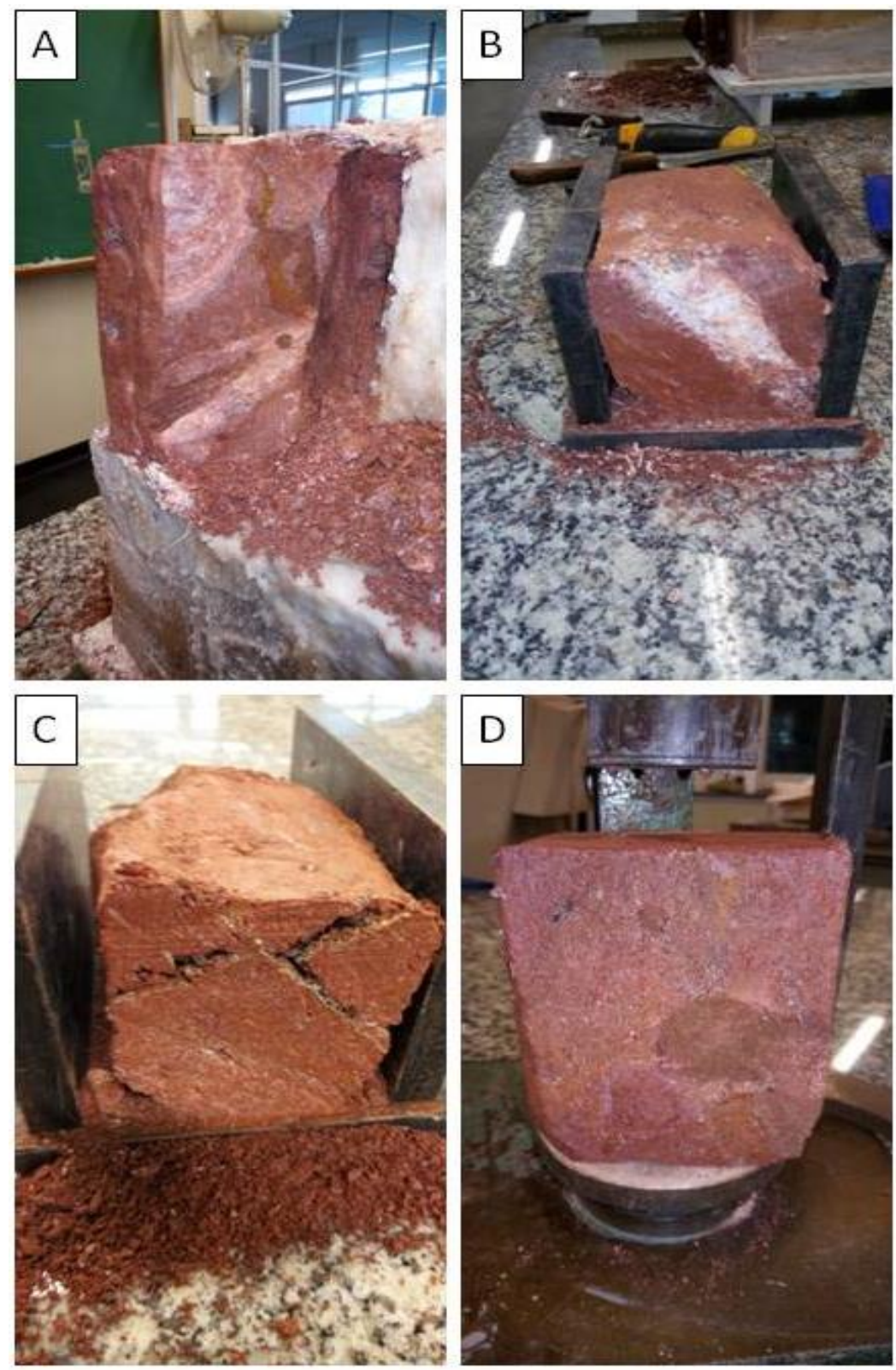

Figura 26. Estruturas presentes no solo, observadas durante a moldagem de corpos de prova em amostra indeformada. (a) bolsões e bandamento herdados da rocha mãe; (b) bolsões quartzo-feldspáticos associados à veios de quartzo; (c) Fraturas preenchida por argilominerais e óxido e hidróxido de ferro; e em (d) núcleos de material poroso de coloração marrom

ABEF (1989) realizou mapeamento de detalhe em dois poços de inspeção, de profundidade de 8,7 metros, no campo experimental da USP. As estruturas 
observadas nos blocos indeformados também foram identificadas em profundidade, mostrando que o solo apresenta heterogeneidade de modo pervasivo. A Figura 27 traz este mapeamento, ilustrando as relações de contato das estruturas descritas.
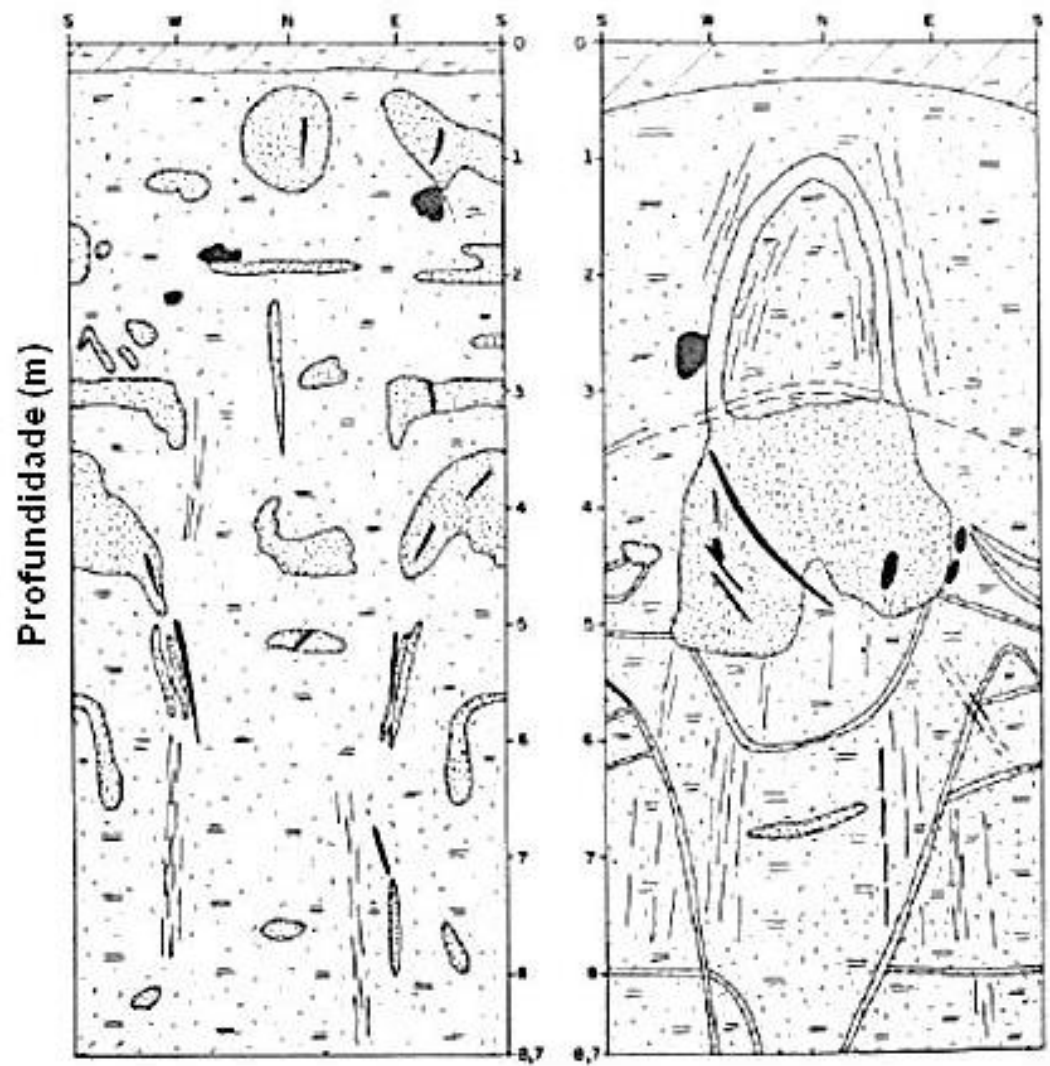

\section{LEGENDA}

Solo colıvionar

Solo saprolítico

Núcleos caoliníticos

Veios caoliniticos

Veios fle quartzo

Núcleos síltico-

argilosos porosos marrons

Foliaçäo

Fraturas

Figura 27. Mapeamento de detalhes em poços de inspeção (ABEF, 1989)

\subsection{Ensaios de Caracterização}

Ensaios de caracterização foram realizados para cada um dos blocos indeformados coletados. Foram executados os seguintes ensaios: granulometria, limite de liquidez, limite de plasticidade e densidade dos grãos. Estes ensaios foram realizados de acordo com as seguintes normas:

- Granulometria: NBR-7181/1984

- Densidade dos grãos: NBR-6508/1984

- Limite de liquidez: NBR-6459/1984

- Limite de plasticidade: NBR-7180/1984

A preparação da amostra foi realizada de acordo com a norma NBR-6457/1984. O solo analisado apresenta porcentagem de material retido na peneira 40 menor que 
$10 \%$ e os ensaios foram realizados com secagem prévia. No ensaio de granulometria, foi utilizado defloculante na fase de sedimentação.

As curvas granulométricas obtidas para os blocos A, B e C estão indicadas na Figura 28 e as frações granulométricas presentes em cada bloco estão indicadas na Tabela 4.

Tabela 4. Frações granulométricas presentes nos blocos A, B e C

\begin{tabular}{ccccccc}
\hline & \% argila & \% silte & \% areia fina & $\begin{array}{c}\text { \% areia } \\
\text { média }\end{array}$ & $\begin{array}{c}\text { \% areia } \\
\text { grossa }\end{array}$ & Pedregulho \\
\hline Bloco A & 12 & 68 & 16 & 1 & 1 & 2 \\
\hline Bloco B & 22 & 60 & 10 & 6 & 2 & 0 \\
\hline Bloco C & 12 & 72 & 14 & 2 & 0 & 0 \\
\hline
\end{tabular}

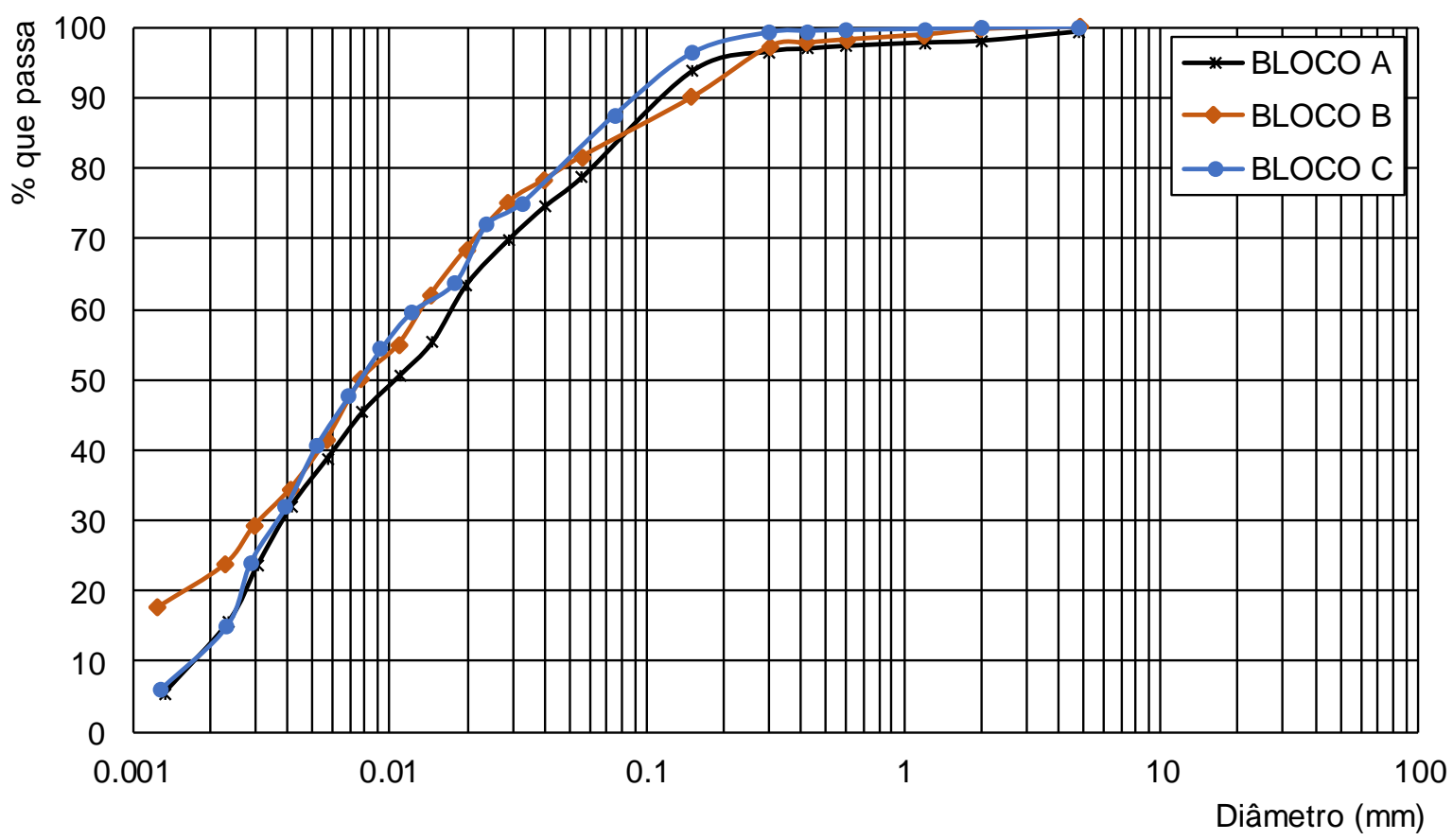

Figura 28. Curvas granulométricas

Os valores de densidade dos grãos obtidos foram $2,71 \mathrm{~g} / \mathrm{cm}^{3}, 2,62 \mathrm{~g} / \mathrm{cm}^{3}$ e $2,75 \mathrm{~g} / \mathrm{cm}^{3}$ para os blocos A, B e C, respectivamente. A Figura 29 apresenta a carta de plasticidade de Casagrande, indicando a classificação dos blocos analisados. Como pode ser observado, o bloco A foi classificado como um silte de alta plasticidade (MH) e os blocos $\mathrm{B}$ e $\mathrm{C}$ foram classificados com um silte baixa plasticidade. 


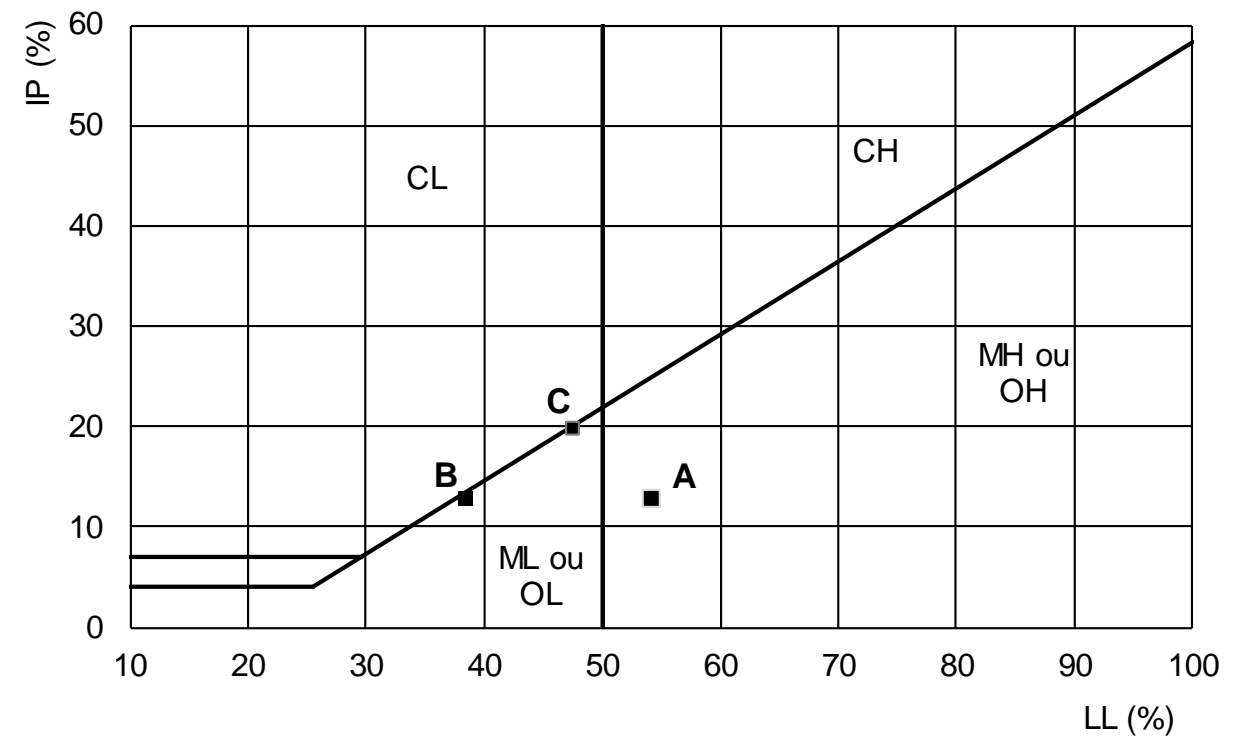

Figura 29. Classificação do solo na carta de plasticidade de Casagrande

\subsection{Comparação com a Literatura}

As propriedades geotécnicas deste solo também foram estudadas por ABEF (1989), Stuermer (1998), Vieira (1999), Oliveira (2004), Guzmán (2014) e Orlando (2015), entre outros. Os resultados dos ensaios de caracterização obtidos por estes autores estão apresentados na Ensaios de caracterização - comparativo com os dados da literatura (frações granulométricas, limites de Atterberg e densidade dos grãos), juntamente os resultados obtidos no presente estudo. Stuermer (1989) e Vieira (1999) realizaram ensaios de caracterização em mais de uma amostra, nestes casos estão apresentados os valores máximos, mínimos e a média dos resultados obtidos por estes autores.

ABEF (1989) realizou um estudo detalhado da área estudada, com realização de diversos ensaios laboratoriais e in situ. Em uma das análises, foram realizados ensaios especiais e de caracterização comparando o comportamento de duas porções distintas do solo: os bolsões quartzo-caoliníticos (ilustrado na Figura 26a) e a porção avermelhada do solo (provável paleossoma). ABEF (1989) denominou estas porções do solo como caulim e migmatito, respectivamente. Os resultados dos ensaios de caracterização de cada uma destas porções também estão indicados na Tabela 5. 
Tabela 5. Ensaios de caracterização - comparativo com os dados da literatura (frações granulométricas, limites de Atterberg e densidade dos grãos)

\begin{tabular}{|c|c|c|c|c|c|c|c|c|c|c|}
\hline & & \multirow{2}{*}{\multicolumn{6}{|c|}{ Frações granulométricas }} & \multirow{2}{*}{\multicolumn{2}{|c|}{ Limites de Atterberg }} & \multirow{3}{*}{$\underset{\left(\mathrm{g} / \mathrm{cm}^{3}\right)}{\delta}$} \\
\hline & & & & & & & & & & \\
\hline & & $\%$ argila & $\%$ silte & $\begin{array}{c}\% \text { areia } \\
\text { fina }\end{array}$ & $\begin{array}{c}\% \text { areia } \\
\text { média }\end{array}$ & $\begin{array}{c}\% \text { areia } \\
\text { grossa }\end{array}$ & $\begin{array}{c}\% \\
\text { pedregulho }\end{array}$ & LL (\%) & IP (\%) & \\
\hline \multirow[b]{2}{*}{ ABEF (1989) } & Migmatito & 7 & 74 & 18 & 1 & 0 & 0 & 54 & 18 & 2.73 \\
\hline & $\begin{array}{l}\text { Bolsões } \\
\text { caoliniticos }\end{array}$ & 18 & 50 & 22 & 8 & 2 & 0 & 38 & 12 & 2.63 \\
\hline \multirow{3}{*}{ Stuermer (1998) } & máximo & 53.6 & 18.4 & 28.2 & 5.7 & 4.4 & 0 & 49 & 20 & 2.75 \\
\hline & mínimo & 48.3 & 14.7 & 21.5 & 3.2 & 3 & 0 & 48 & 18 & 2.73 \\
\hline & média & 50.8 & 16.06 & 25.36 & 4.22 & 3.76 & 0 & 48.4 & 19.4 & 2.74 \\
\hline \multirow{3}{*}{ Vieira (1999) } & máximo & 37 & 39 & 37 & 6 & 4 & 1 & 57 & 29 & 2.769 \\
\hline & mínimo & 22 & 26 & 29 & 3 & 1 & 0 & 47 & 9 & 2.512 \\
\hline & média & 28 & 33 & 32 & 5 & 2 & 1 & 51 & 17 & 2.697 \\
\hline Oliveira (2004) & & 20 & 46 & 28 & 6 & 0 & 0 & 47 & 13 & 2.71 \\
\hline Guzmán (2013) & & 23 & 45 & 28 & 4 & 0 & 0 & 48 & 19 & 2.71 \\
\hline Orlando (2015) & & 13 & 63 & 16 & 6 & 1 & 1 & 51 & 10 & 2.735 \\
\hline \multirow[t]{3}{*}{ Estudo atual } & bloco A & 12 & 68 & 16 & 1 & 1 & 2 & 54 & 12 & 2.71 \\
\hline & bloco B & 22 & 60 & 10 & 6 & 2 & 0 & 38 & 13 & 2.62 \\
\hline & bloco C & 12 & 72 & 14 & 2 & 0 & 0 & 47 & 20 & 2.75 \\
\hline
\end{tabular}

O solo foi caracterizado como um silte arenoso por grande parte dos autores, porém foi observada uma grande variação na análise granulométrica. O teor de silte e argila foi muito variável entre as análises, com variações de até $47 \%$. Os limites de plasticidade e liquidez também apresentarem variações, como observado na carta de plasticidade da Figura 30. Tais diferenças estão associadas ao grau de intemperismo das amostras analisadas e a elevada heterogeneidade, típica de solos residuais.

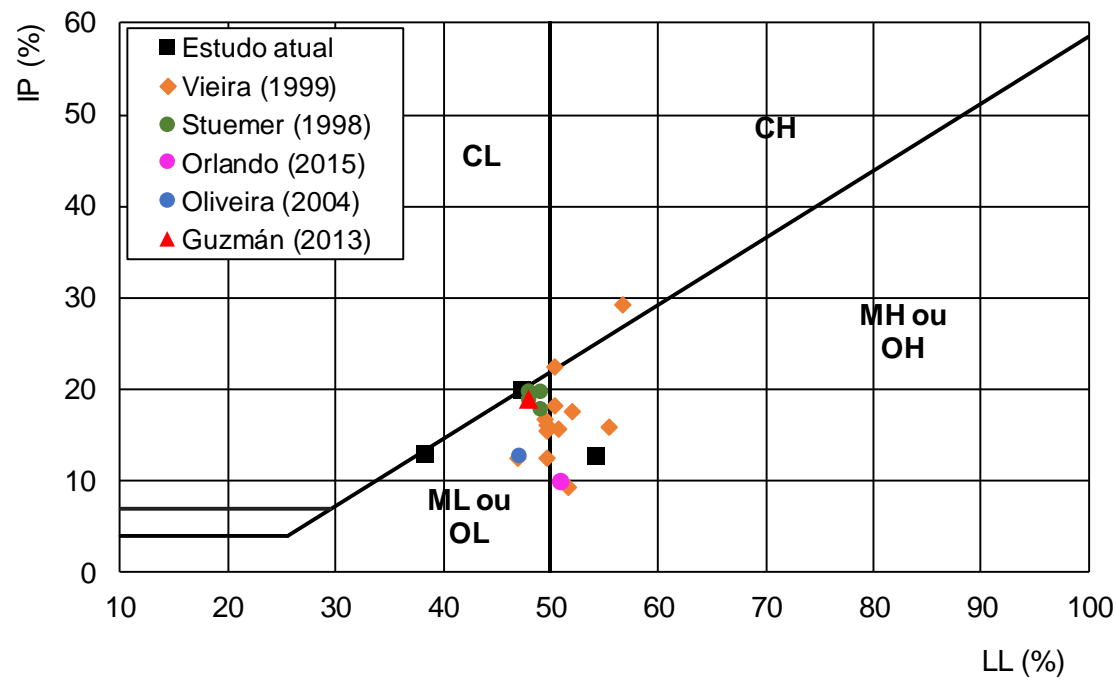

Figura 30. Carta de plasticidade de Casagrande com indicação dos dados obtidos na literatura e do presente estudo

$\mathrm{Na}$ Tabela 6 estão apresentados os parâmetros de resistência encontrados na literatura do solo em estudo. Embora boa parte dos autores tenham realizados ensaios 
em amostras compactadas do solo residual, estas informações permitem uma avaliação do aspecto estrutural do material.

Tabela 6. Parâmetros de resistência do solo em estudo

\begin{tabular}{|c|c|c|c|c|}
\hline & $\begin{array}{c}\text { Tipo de } \\
\text { ensaio }\end{array}$ & Tipo de amostra & $\begin{array}{c}\text { c ou c' } \\
(\mathrm{kPa})\end{array}$ & $\begin{array}{c}\varphi \text { ou } \varphi^{\prime} \\
\left(^{\circ}\right)\end{array}$ \\
\hline \multirow{6}{*}{ ABEF (1989) } & \multirow{3}{*}{$C D$} & \multirow{3}{*}{ Indeformada } & 42.13 & 26 \\
\hline & & & 71.08 & 23 \\
\hline & & & 93.29 & 23 \\
\hline & $\mathrm{CU}$ & Indeformada & 116.28 & 28 \\
\hline & \multirow{2}{*}{$C D$} & Indeformada - Migmatito & 99.75 & 25 \\
\hline & & Indeformada - caulim & 34.83 & 23 \\
\hline \multirow{2}{*}{ Vieira (1999) } & \multirow{2}{*}{ CAU } & \multirow{2}{*}{ Indeformada } & 8.7 & 23 \\
\hline & & & 16 & 32 \\
\hline \multirow{4}{*}{ Oliveira (2004) } & \multirow{3}{*}{ CAU } & Compactada - umidade ótima & 12 & 32 \\
\hline & & Compactada - ramo seco & 5 & 34 \\
\hline & & Compactada - ramo úmido & 9 & 32 \\
\hline & CAD & Compacta - umidade ótima & 12 & 30 \\
\hline \multirow{3}{*}{ Guzmán (2013) } & \multirow{3}{*}{ CIU } & Compactada - umidade ótima & 21.4 & 29 \\
\hline & & Compactada - ramo úmido & 17.6 & 31 \\
\hline & & Compactada - ramo úmido & 15.5 & 28 \\
\hline \multirow{3}{*}{ Orlando (2015) } & \multirow{3}{*}{ CIU } & Compactada - umidade ótima & 27 & 27 \\
\hline & & Compactada - ramo seco & 27 & 29 \\
\hline & & Compactada - ramo úmido & 21 & 27 \\
\hline
\end{tabular}

Em amostras indeformadas, o ângulo de atrito efetivo variou entre $20^{\circ}$ e $32^{\circ}$ e a coesão efetiva apresentou uma elevada variabilidade, entre $8,7 \mathrm{kPa}$ e $116 \mathrm{kPa}$, indicando, mais uma vez, a elevada heterogeneidade deste solo. $\mathrm{O}$ ângulo de atrito do material indeformado variou de $23^{\circ}$ a $32^{\circ}$.

A coesão do material compactado indicou valores muito inferiores ao material indeformado, com variabilidade entre $5 \mathrm{kPa}$ e $27 \mathrm{kPa}$. Já o ângulo de atrito apresentou uma variação entre $27^{\circ}$ e $34^{\circ}$. A média do ângulo de atrito do material compactado foi ligeiramente superior ao do indeformado.

Devido a elevada variabilidade dos dados compilados, a adoção destes valores como parâmetros de projeto deve ser realizada com cautela, considerando a porção do solo de interesse. Uma compilação destes dados está apresentada em Lemos e Marinho (2018) 


\section{RESULTADOS}

Este capítulo apresenta os resultados obtidos nos ensaios triaxiais convencionais multi-estágios realizados em amostras indeformadas e compactadas, apresentando as envoltórias de ruptura interpretadas bem como os parâmetros de resistência e deformabilidade obtidos. Os ensaios são identificados pelo ID presente na tabela 3.1.

\subsection{Ensaios Triaxiais do Tipo ClU em Amostras Compactadas}

Com o intuito de comparar o comportamento do solo em ensaio convencionais e multiestágios sem os efeitos da heterogeneidade das amostras, foram realizados ensaios em amostras compactadas (ensaio A e B).

As amostras foram moldadas na umidade ótima e com índice de vazios próximo ao natural. A média do índice de vazios, calculado nos corpos de prova indeformados, é de 0.90 , com desvio padrão de 0.06 .

A umidade ótima deste solo foi obtida a partir da realização de um ensaio proctor normal. A curva de compactação obtida está apresentada na Figura 31, a umidade ótima obtida foi $20.85 \%$. A Tabela 7 apresenta as características iniciais dos corpos de prova moldados.

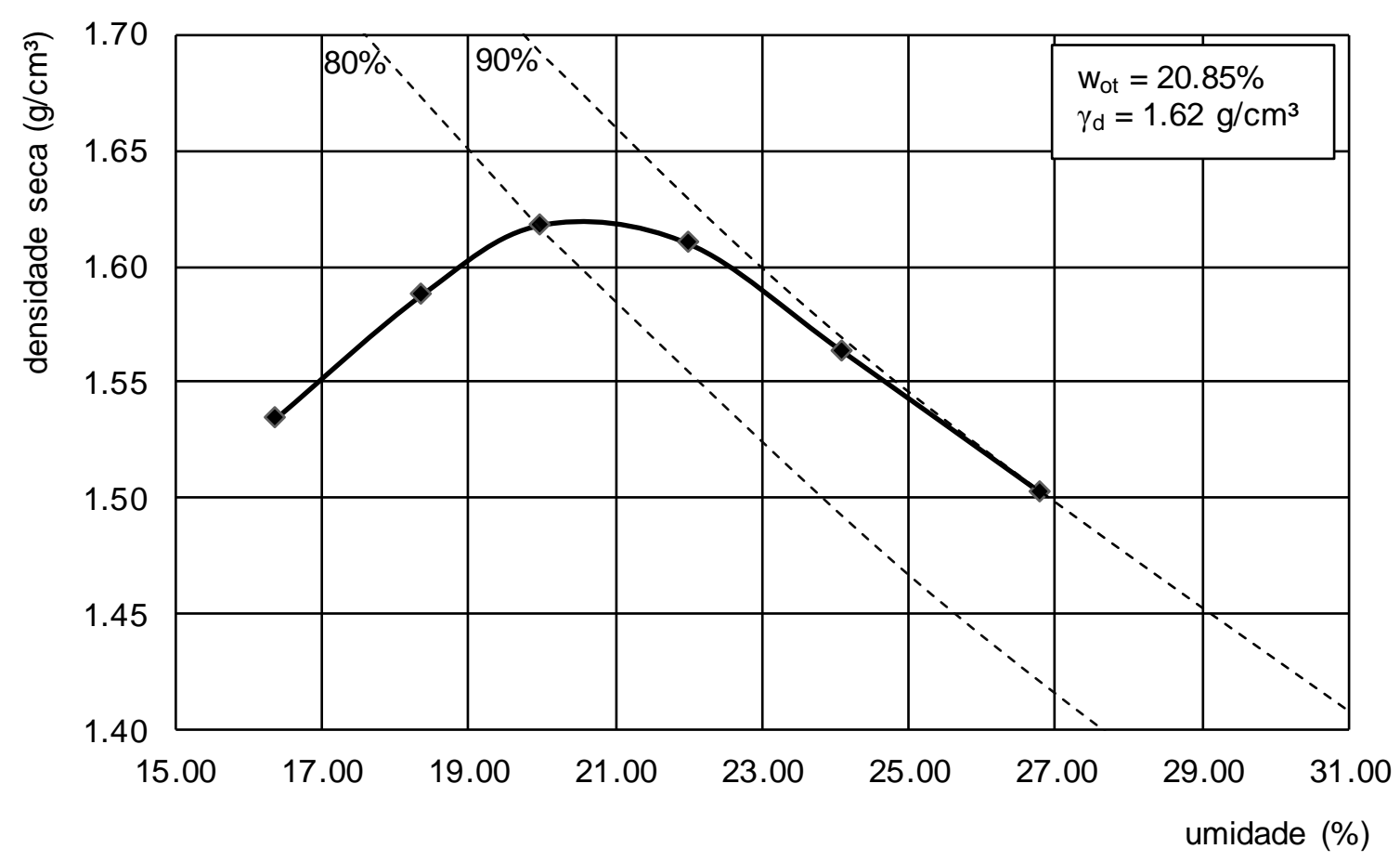

Figura 31. Curva de compactação obtida com energia normal 
Tabela 7 . Características dos corpos de prova compactados utilizados nos ensaios A e B

\begin{tabular}{|lr|c|c|c|c|}
\hline ID & \multicolumn{2}{|c|}{ A } & B \\
\hline ENSAIO & & C-ClU-100 kPa & C-ClU-200 kPa & C-CIU-300 kPa & $\begin{array}{c}\text { ME-CIU-100,200,300 } \\
\text { kPa }\end{array}$ \\
\hline umidade inicial & $\%$ & 20.94 & 20.94 & 20.94 & 20.94 \\
\hline Área da seção & $\mathrm{cm}^{2}$ & 11.40 & 11.36 & 11.34 & 11.38 \\
\hline Volume & $\mathrm{cm}^{3}$ & 91.28 & 92.32 & 89.74 & 90.85 \\
\hline Peso úmido & $\mathrm{g}$ & 150.23 & 150.45 & 149.76 & 149.67 \\
\hline Peso seco & $\mathrm{g}$ & 124.22 & 124.40 & 123.83 & 123.76 \\
\hline Densidade úmida & $\mathrm{g} / \mathrm{cm}^{3}$ & 1.65 & 1.63 & 1.67 & 1.65 \\
\hline Densidade seca & $\mathrm{g} / \mathrm{cm}^{3}$ & 1.36 & 1.35 & 1.38 & 1.36 \\
\hline índice de vazios & & 0.99 & 1.01 & 0.96 & 0.99 \\
\hline S inicial & $\%$ & 57.24 & 56.12 & 58.87 & 57.35 \\
\hline Umidade após aspersão & $\%$ & 33.99 & 31.49 & 32.50 & 35.78 \\
\hline
\end{tabular}

5.2.1. Ensaio convencional em amostra compactada (ensaio A: C-CIU$100,200,300 \mathrm{kPa})$

Foram realizados três ensaios triaxiais convencionais do tipo CIU, com tensões de adensamento de $100 \mathrm{kPa}, 200 \mathrm{kPa}$ e $300 \mathrm{kPa}$ (ensaio A). As características iniciais dos corpos de provas utilizados estão apresentadas na tabela 7 e as imagens das amostras após a ruptura estão apresentadas na Figura 32. Os gráficos de tensão desviatória e variação de poro-pressão versus deformação estão apresentados na Figura 33.

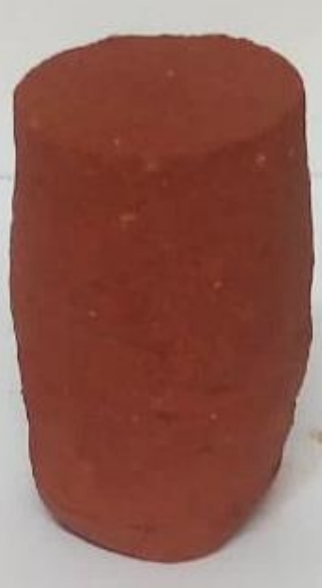

C-CIU-100 kPa

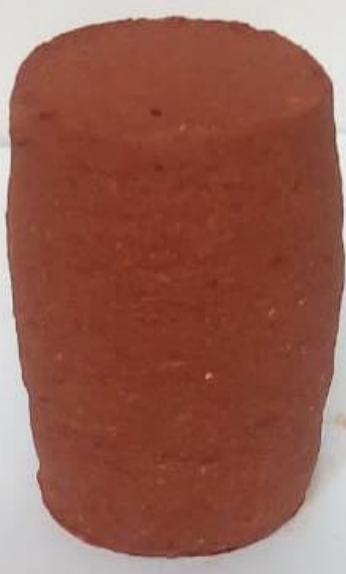

C-CIU-200 kPa

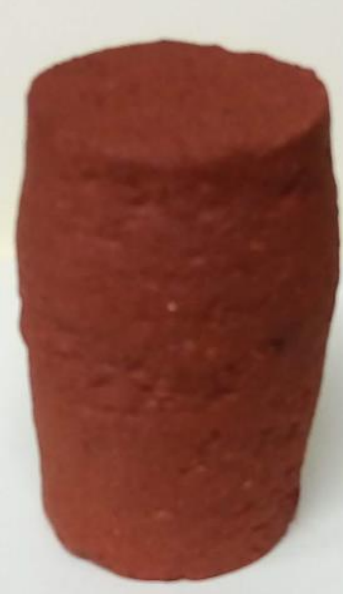

C-CIU-300 kPa

Figura 32. Corpos de prova compactados após ensaio de cisalhamento triaxial (ensaio A) 

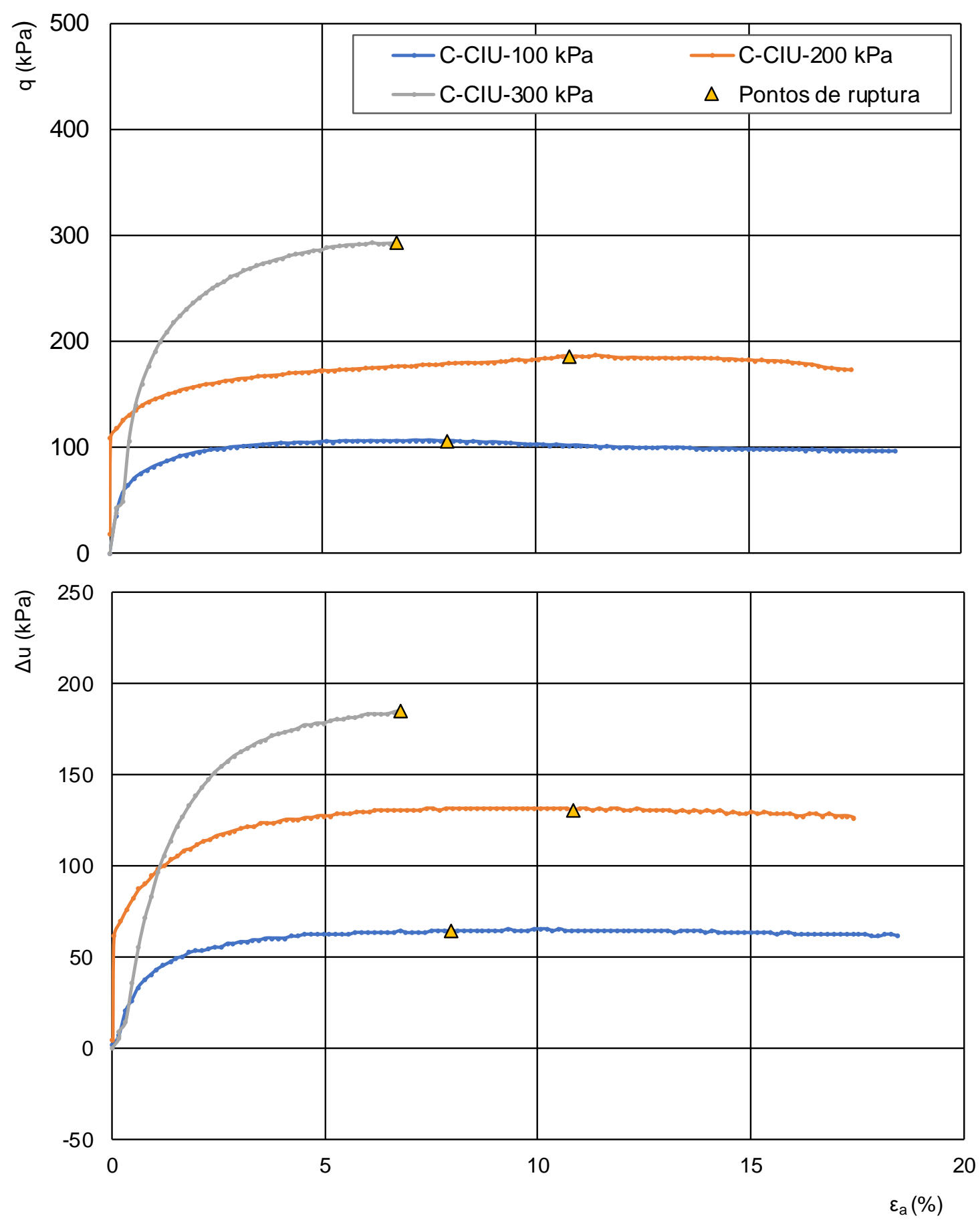

Figura 33. Resultados do ensaio A - curvas de tensão-deformação e variação de poropressões versus deformação axial

Como pode ser observado, nos três ensaios realizados a tensão desviatória tende a estabilizar após a ruptura, numa tensão próxima à máxima. A estabilização da tensão ocorre em taxas de deformação acima de $7 \%$. No gráfico de tensão-deformação normalizado (Figura 34), observa-se uma pequena queda da tensão desviatória após a ruptura, em todos os três ensaios realizados. 
Em relação à variação de poro-pressões, nos três ensaios realizados, ocorre aumento da pressão neutra até o momento da ruptura, em seguida, as poro-pressões são estabilizadas.

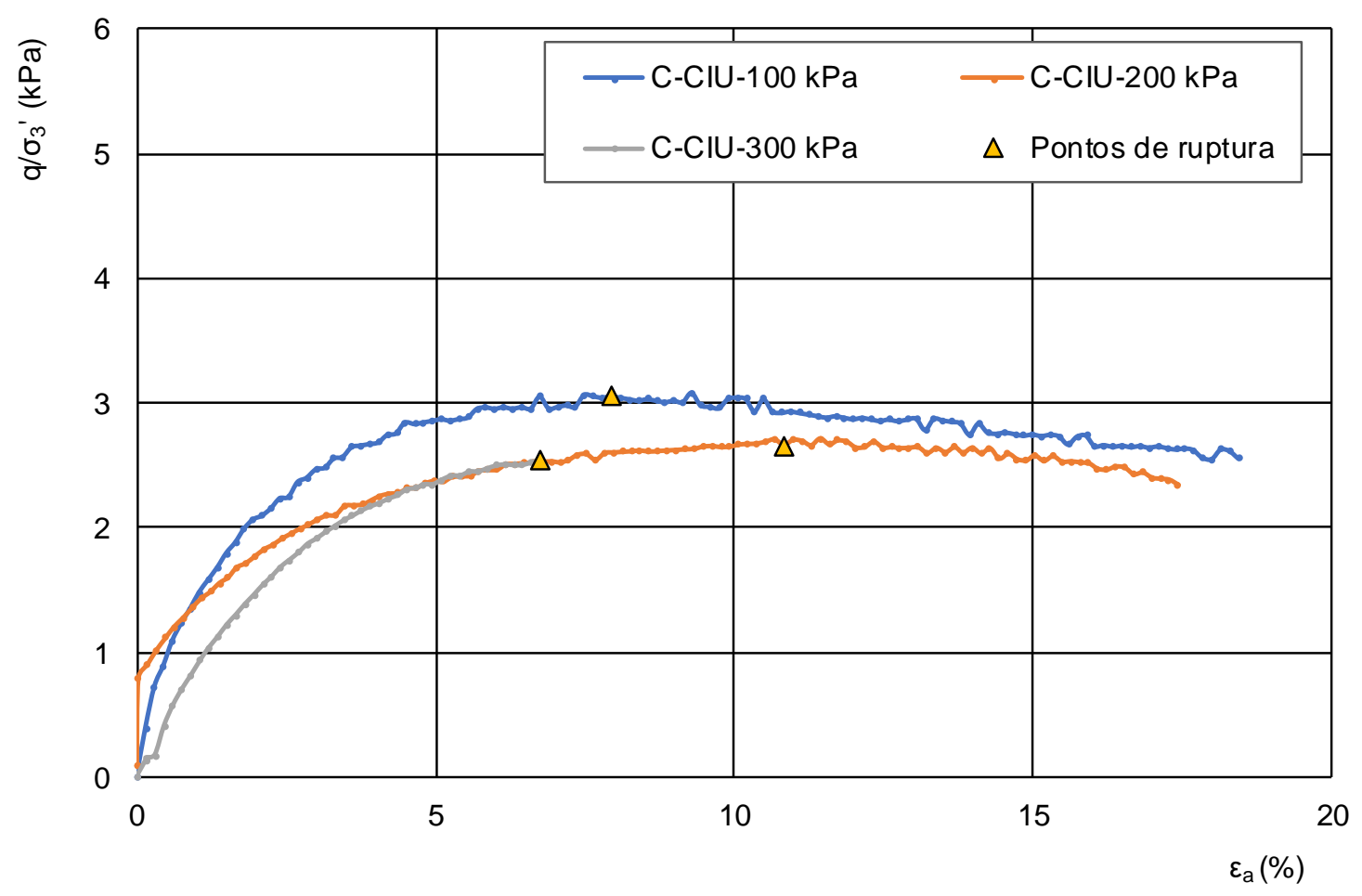

Figura 34. Resultados do ensaio A - curvas de tensão-deformação normalizadas

As Figura 35 e 36 apresentam, respectivamente, as trajetórias de tensão e os círculos de Mohr obtidos, com a envoltória de ruptura interpretada. Os parâmetros de resistência obtidos foram: $c^{\prime}=2 \mathrm{kPa}$ e $\varphi^{\prime}=34^{\circ}$. Os valores obtidos são compatíveis com os disponíveis na literatura (apresentados no item 4.5).

A Figura 37 apresenta os valores de deformabilidade secante relacionados às deformações durante o cisalhamento. Foram obtidos módulos de deformação a partir 0,01\% de deformação axial, porém, por se tratar de um ensaio isotrópico, ressalta-se que os módulos obtidos em baixas deformações podem ser afetados pela mecânica do ensaio, que leva em consideração deformações externas ao corpo de prova. A Figura 38 traz os módulos de deformabilidade secantes normalizados pela tensão efetiva média ( $\left.p^{\prime}\right)$. 


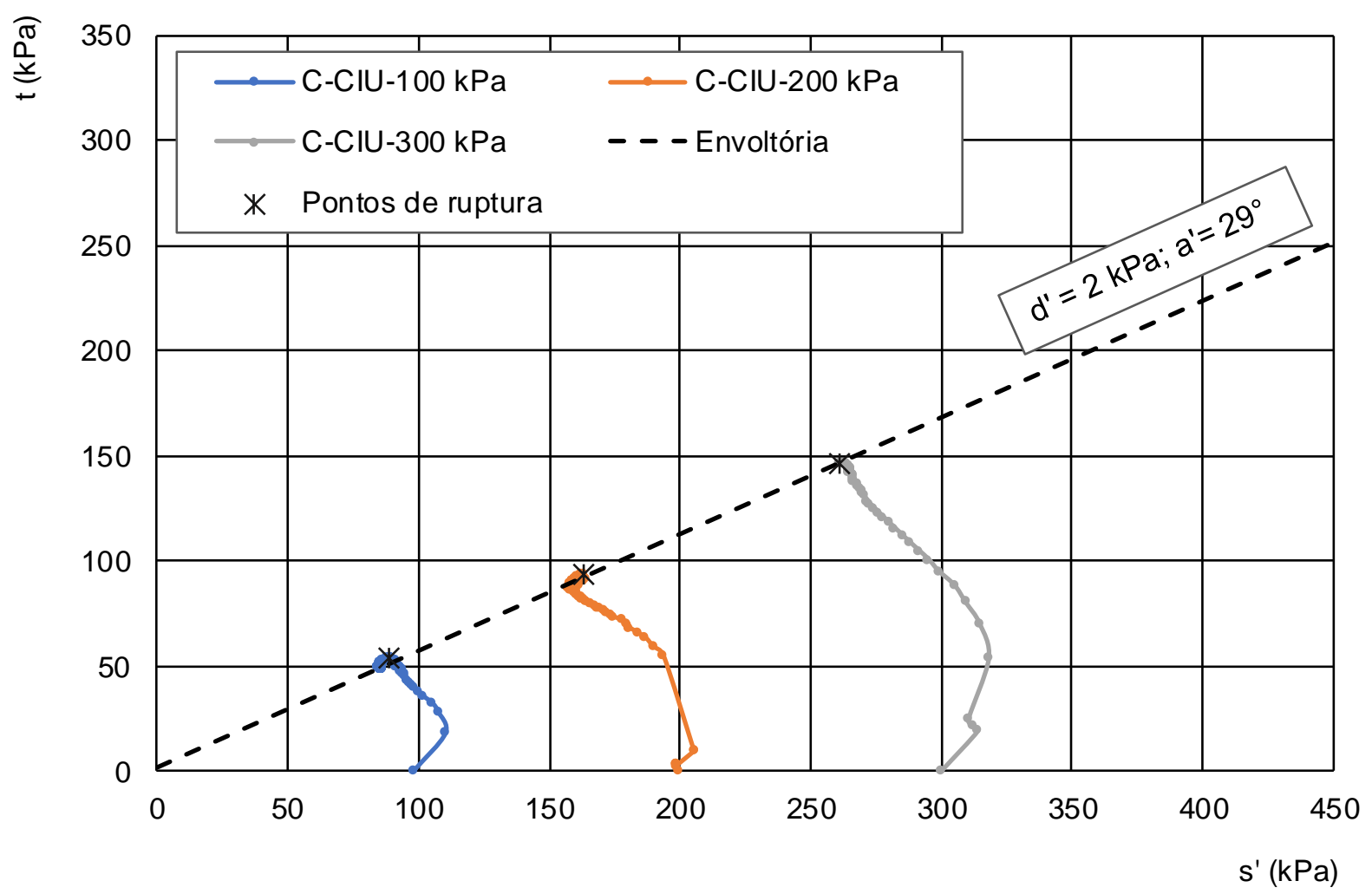

Figura 35. Resultados do ensaio A - trajetórias de tensão

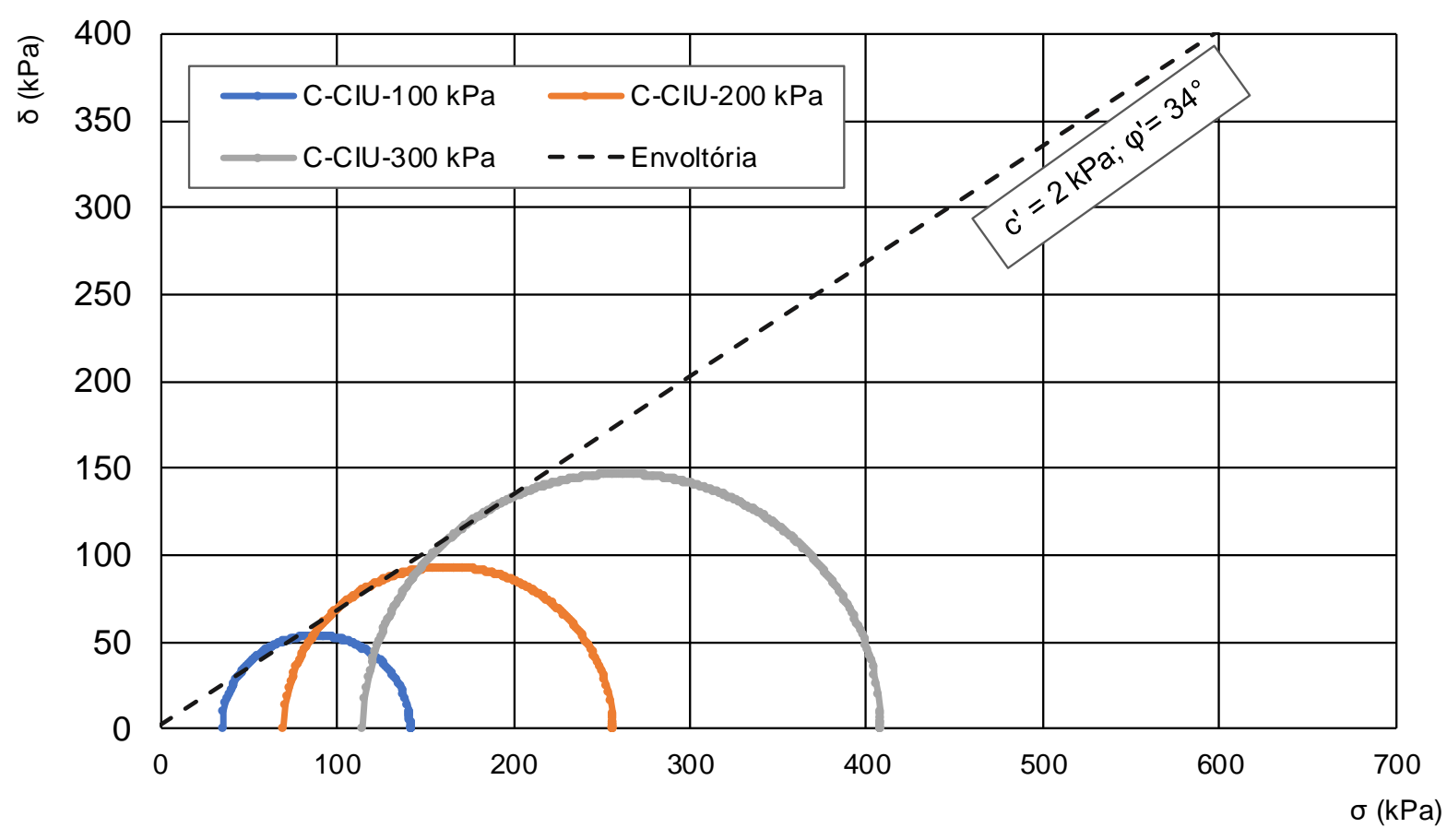

Figura 36. Resultados do ensaio A - Círculos de Mohr e envoltória de ruptura 


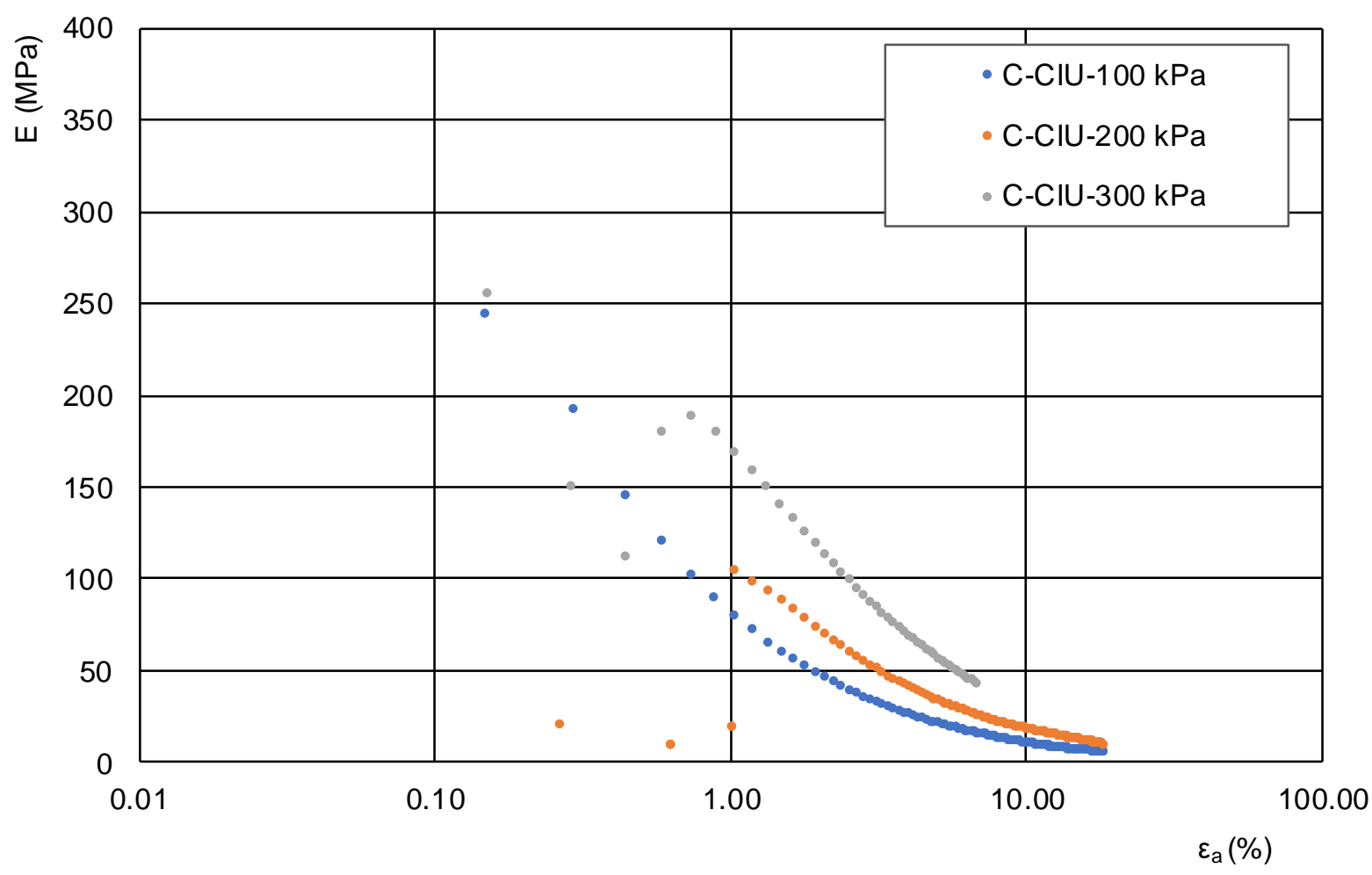

Figura 37. Resultados do ensaio A - Módulos de deformabilidade

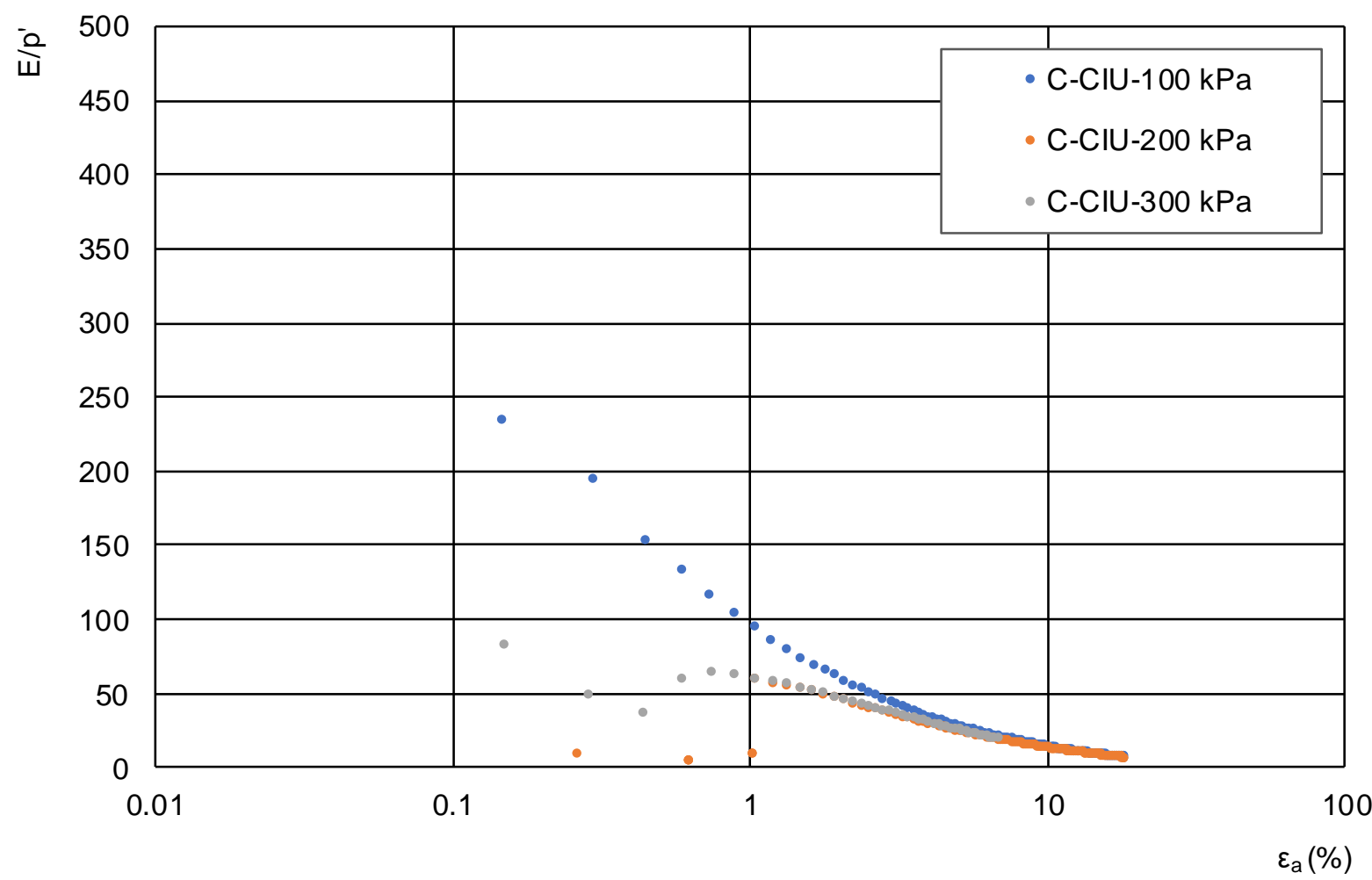

Figura 38. Resultados do ensaio A - Módulos de deformabilidade normalizados pela tensão efetiva média 


\subsubsection{Ensaio multi-estágio em amostra compactada (ensaio B: ME-CIU- $100,200,300 \mathrm{kPa})$}

Foi realizado um ensaio triaxial multi-estágio do tipo CIU em uma amostra compactada, com tensões de adensamento de 100 kPa, 200 kPa e 300 kPa (ensaio B). As características iniciais do corpo de prova ensaiado estão apresentadas na Tabela 7 e a Figura 39 traz a foto do corpo de prova após cisalhamento. Não ocorreu formação de plano de ruptura evidente, e o corpo de prova apresentou-se com embarrigamento.

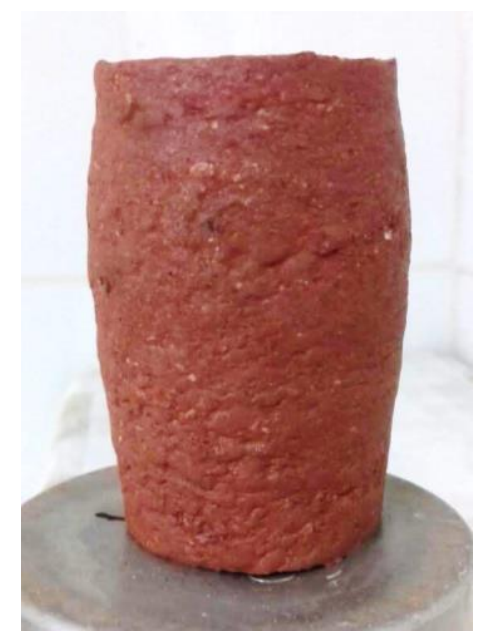

Figura 39. Corpo de prova compactado após ruptura - ensaio B

Os gráficos de tensão versus deformação e de variação de poro-pressão versus deformação estão presentes na Figura 39. Como descrito no item 3.4.4, os pontos de ruptura dos estágios iniciais de cisalhamento foram inferidos de acordo com 0 comportamento do solo no último estágio, onde o ensaio é continuado após a ruptura. Os trechos inferidos estão indicados com uma linha tracejada.

No ensaio com tensão de adensamento de $200 \mathrm{kPa}$, ocorreu uma queda de tensão desviatória durante a fase de cisalhamento, devido à um problema operacional do equipamento. Porém, está queda parece não ter afetado o resultado final do ensaio.

No último estágio de cisalhamento a tensão desviatória manteve-se estabilizada após a ruptura. Em todos os estágios, ocorreu aumento das poro-pressões até o momento de ruptura. No último estágio, observa-se estabilização da poro-pressão após a ruptura, com uma leve tendência de redução. 

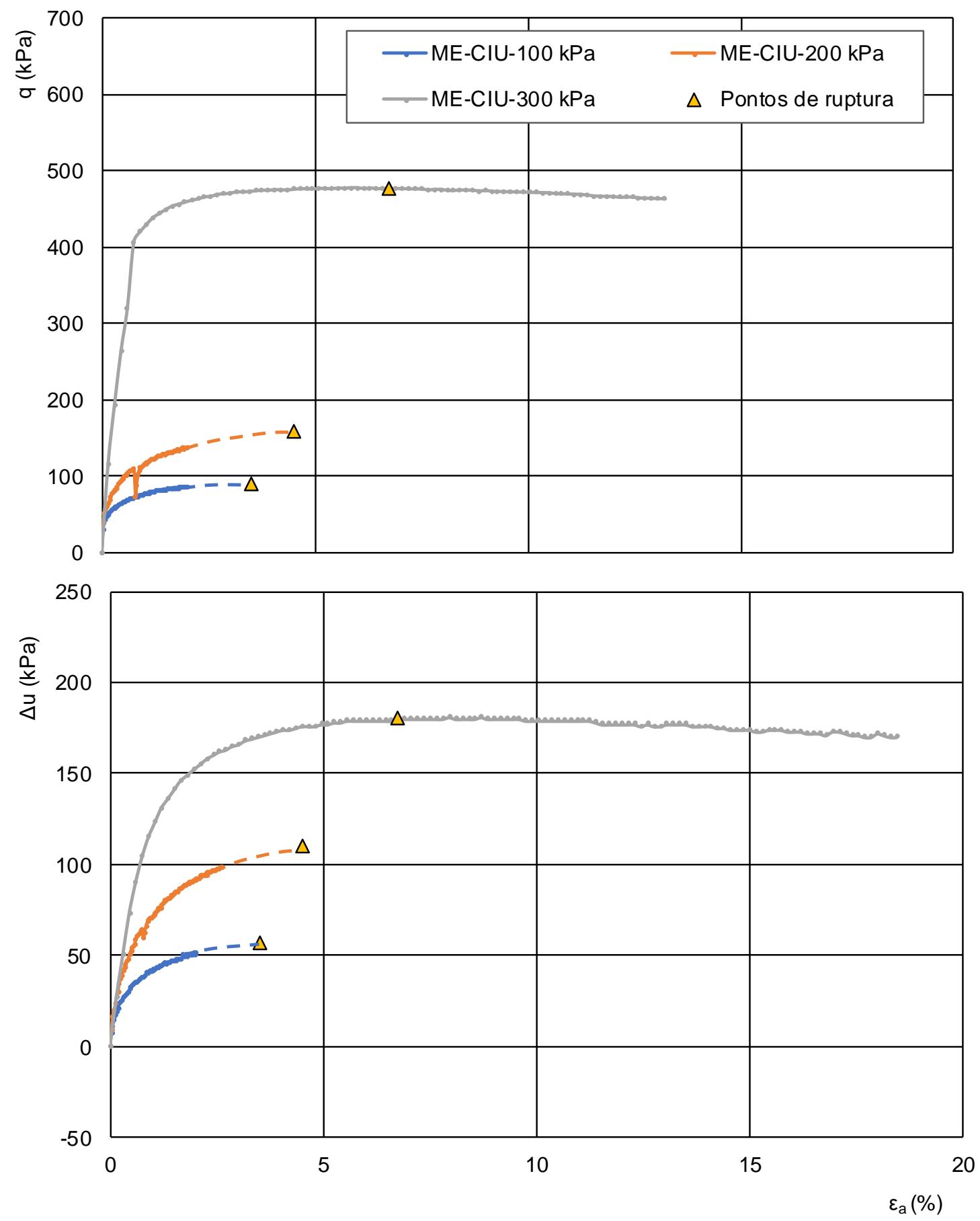

Figura 40. Resultados do ensaio B - curvas de tensão-deformação e variação de pressão neutra

Como pode ser observado na Figura 40, no último estágio de cisalhamento, realizado com tensão de adensamento de $300 \mathrm{kPa}$, a tensão de ruptura é muito elevada, quando comparada aos estágios iniciais. Este fato pode estar associado às perturbações geradas pela aplicação da tensão axial nos estágios anteriores. 
As Figuras 41, 42 e 43 trazem a curva de tensão-deformação normalizada, as trajetórias de tensões e os círculos de Mohr obtido, respectivamente. O ângulo de atrito obtido foi $41^{\circ}$, com coesão nula.

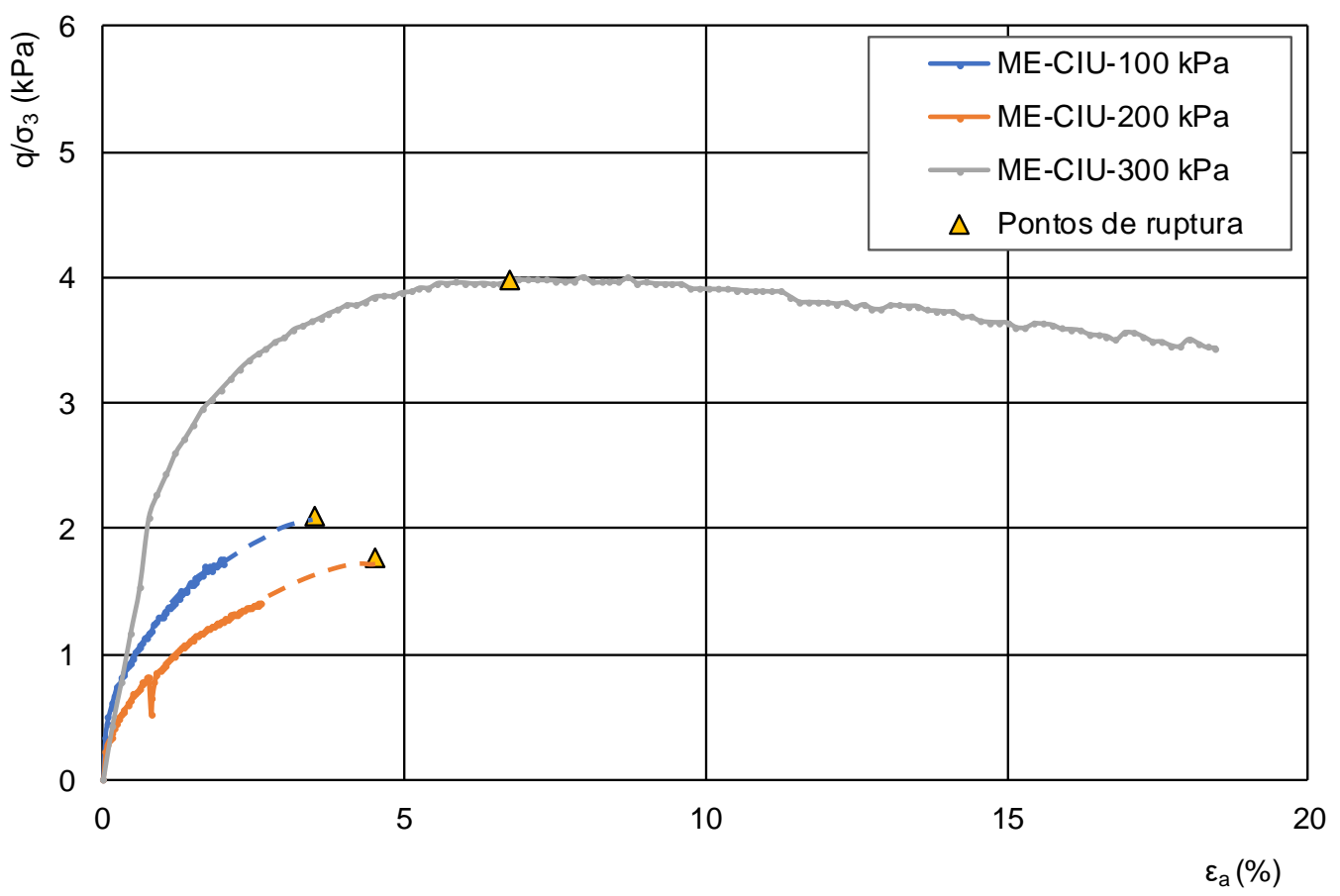

Figura 41. Resultados do e nsaio B - curvas de tensão-deformação normalizadas

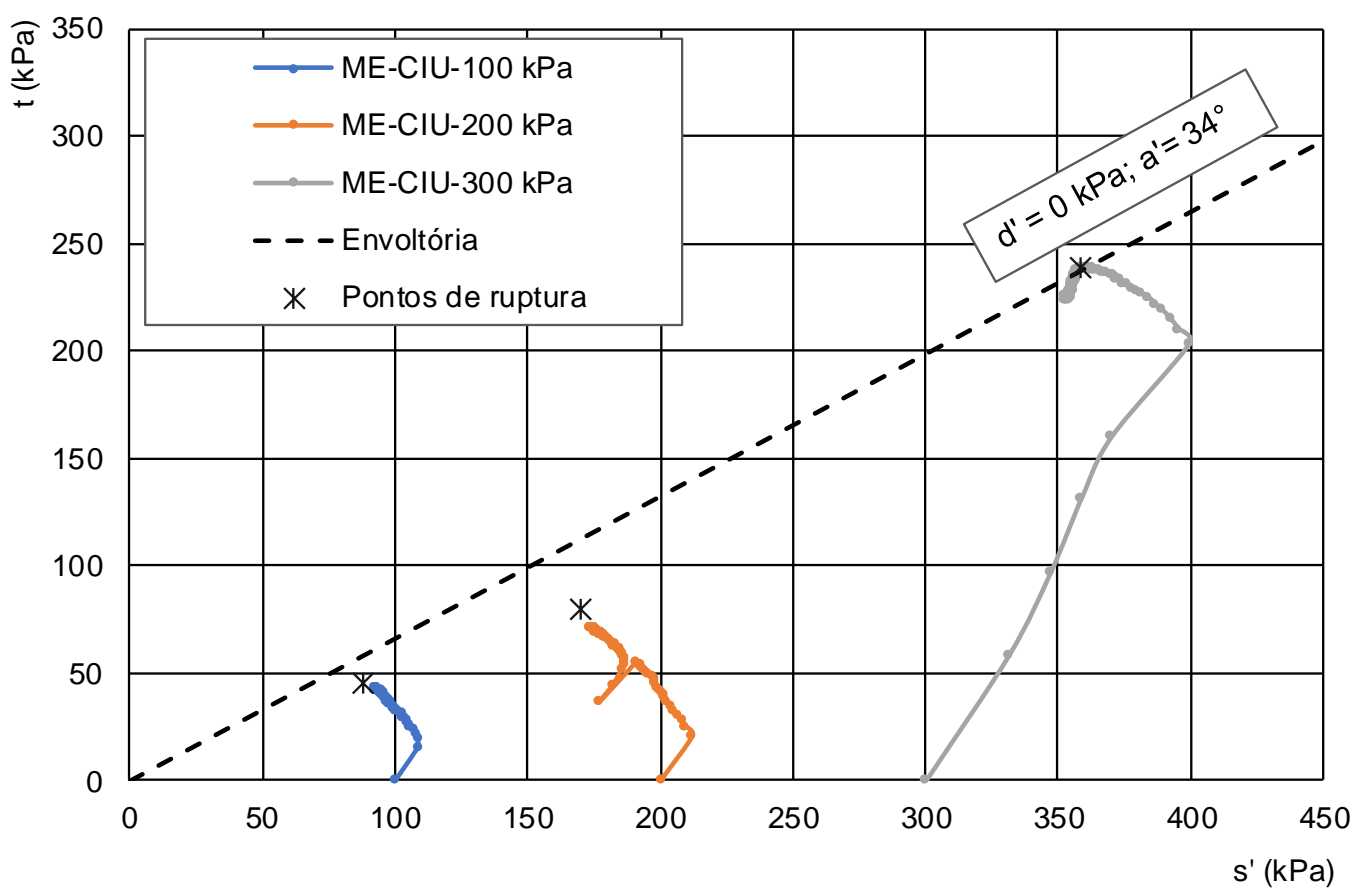

Figura 42. Resultados do ensaio B - trajetórias de tensão 


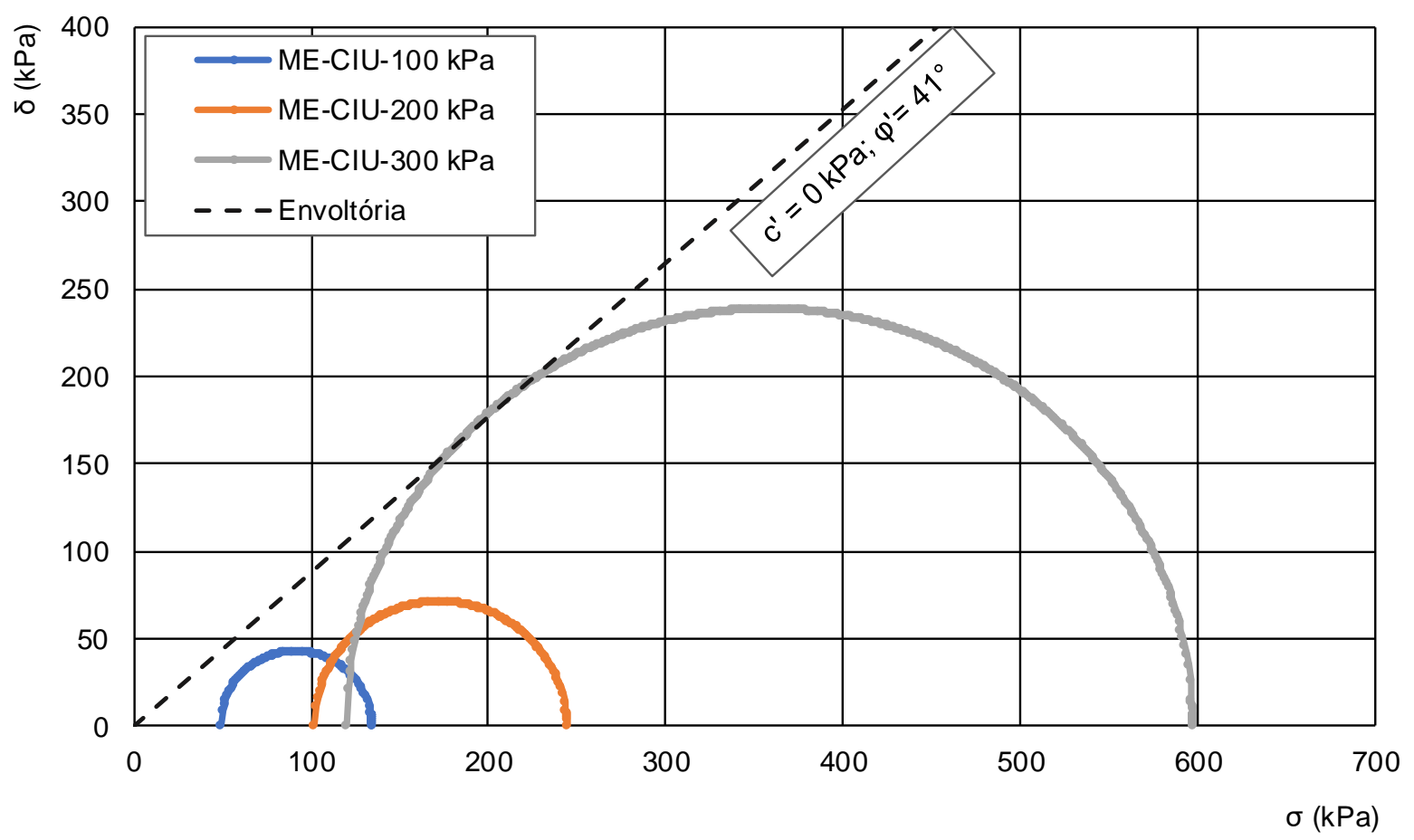

Figura 43. Resultados do ensaio B - círculos de Mohr e envoltória de ruptura

A Figura 44 e a Figura 45 trazem os módulos de deformação secantes e os módulos de deformação normalizados pela tensão efetiva média ( $\left.p^{\prime}\right)$. Observa-se que o último estágio de cisalhamento (300 kPa) apresenta módulos distintos daqueles obtidos nos estágios iniciais.

Contudo, quando se faz a normalização com p', conforme apresentado na Figura 45, as curvas apresentam módulos de deformação com valores muito próximos, em particular, para deformações a partir de 1,00\% 


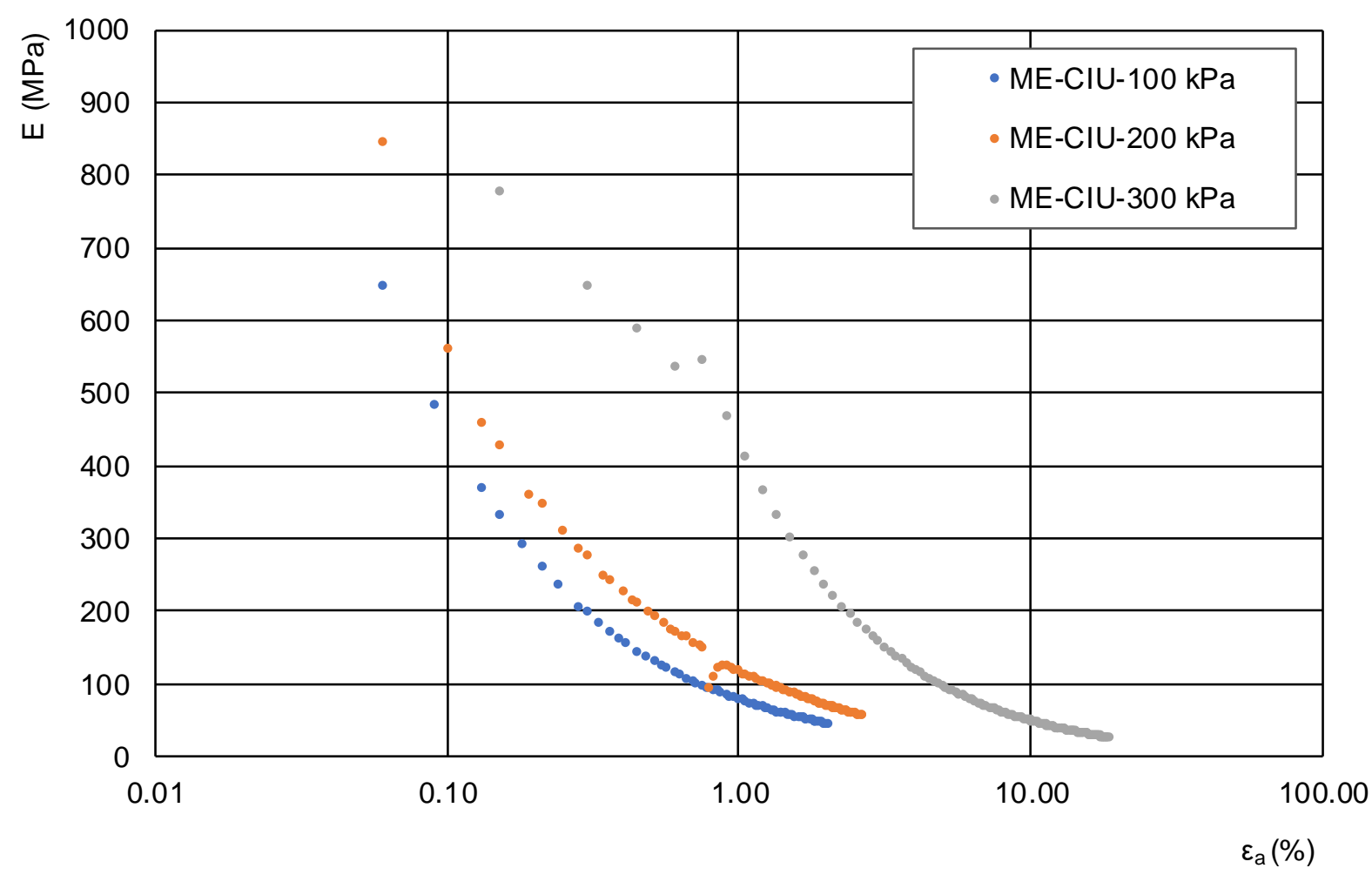

Figura 44. Resultados do ensaio B - módulos de deformabilidade

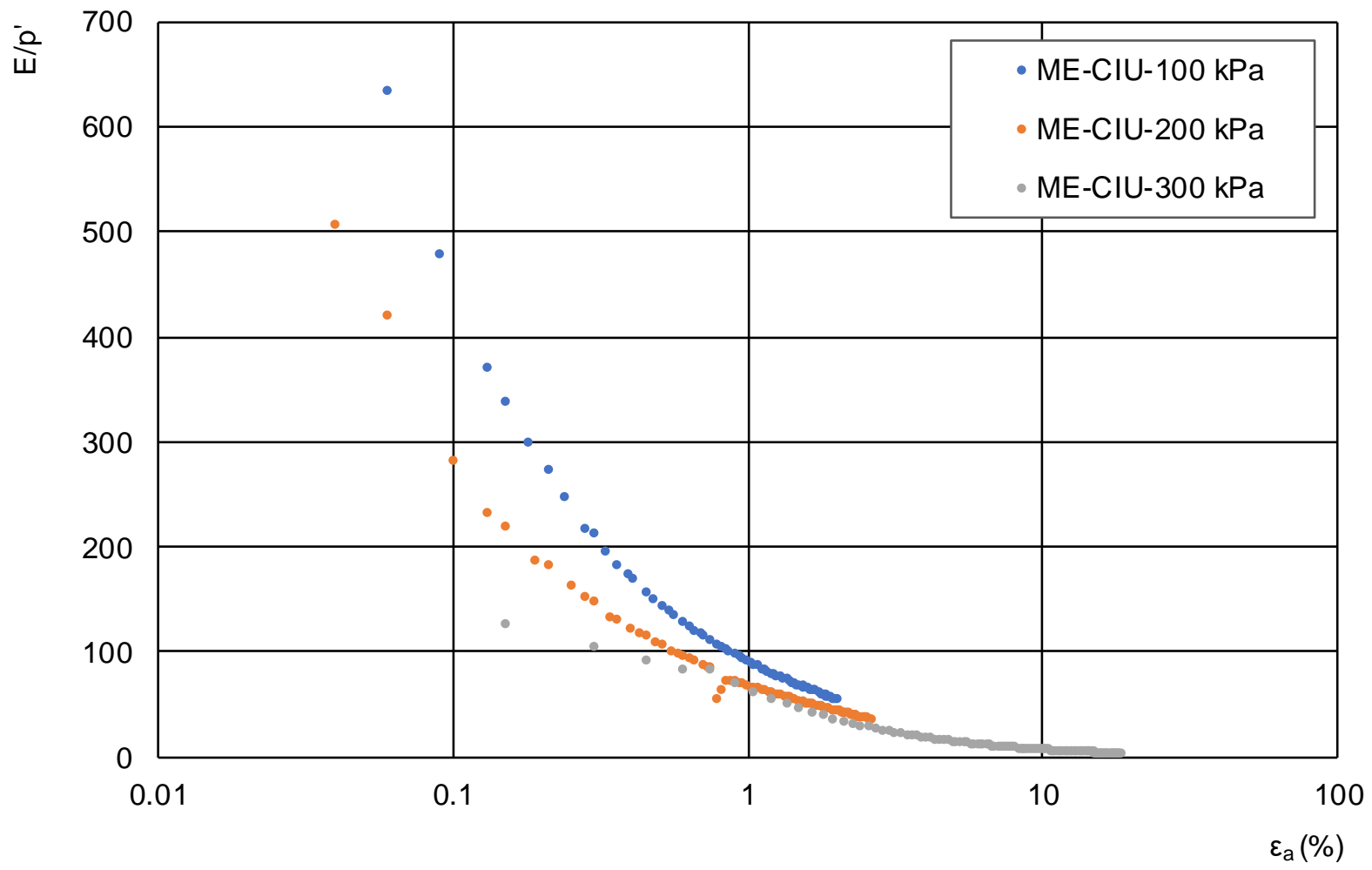

Figura 45. Resultados do ensaio B - módulos de deformação normalizado pela tensão confinante média 


\subsection{Ensaios Triaxiais em Amostras Indeformadas}

Com o objetivo de analisar a validade do uso de ensaios multi-estágios em um solo residual de elevada heterogeneidade, foram realizados ensaios convencionais e multiestágios e seus resultados foram comparados. Os resultados obtidos serão apresentados nos itens a seguir.

\subsubsection{Ensaios triaxiais convencionais em amostras indeformadas}

\subsubsection{Ensaio D: C-CAU-50,100,200,300 kPa}

Foram realizados quatro ensaios convencionais do tipo CAU com tensões de adensamento de $50 \mathrm{kPa}, 100 \mathrm{kPa}, 200 \mathrm{kPa}$ e $300 \mathrm{kPa}$ (ensaio D). Todos os corpos de prova foram adensados anisotropicamente, com uma relação entre tensão confinante e tensão axial igual a 0,7 . A escolha deste valor não possui nenhuma relação com a condição de campo e objetivou apenas melhorar a interpretação dos dados de deformabilidade. As características iniciais de cada um dos corpos de prova estão indicadas na Tabela $8 \mathrm{e}$ as imagens das amostras cisalhadas estão apresentadas na Figura 46. Os corpos de prova foram retirados do bloco A.

Os gráficos de tensão-deformação e de variação de poro-pressões estão apresentados na Figura 47.

Tabela 8. Resultados do ensaio D - características iniciais dos corpos de prova

\begin{tabular}{|lr|c|c|c|c|}
\hline \multicolumn{1}{|l|}{} & \multicolumn{5}{|c|}{ D } \\
\hline ENSAIO & & C-CAU-50 kPa & C-CAU-100 $\mathbf{~ P a ~}$ & C-CAU-200 kPa & C-CAU-300 kPa \\
\hline umidade inicial & $\%$ & 20.07 & 18.91 & 17.96 & 23.51 \\
\hline Área da seção & $\mathrm{cm}^{2}$ & 11.47 & 11.50 & 11.34 & 11.30 \\
\hline Volume & $\mathrm{cm}^{3}$ & 94.61 & 98.39 & 94.33 & 94.82 \\
\hline Peso úmido & $\mathrm{g}$ & 162.25 & 171.97 & 162.48 & 167.26 \\
\hline Peso seco & $\mathrm{g}$ & 135.13 & 144.63 & 137.74 & 135.43 \\
\hline Densidade úmida & $\mathrm{g} / \mathrm{cm}^{3}$ & 1.72 & 1.75 & 1.72 & 1.76 \\
\hline Densidade seca & $\mathrm{g} / \mathrm{cm}^{3}$ & 1.43 & 1.47 & 1.46 & 1.43 \\
\hline índice de vazios & & 0.90 & 0.84 & 0.86 & 0.90 \\
\hline S inicial & $\%$ & 60.61 & 60.73 & 56.87 & 70.98 \\
\hline Umidade após aspersão & $\%$ & - & 28.89 & 28.84 & 34.99 \\
\hline
\end{tabular}




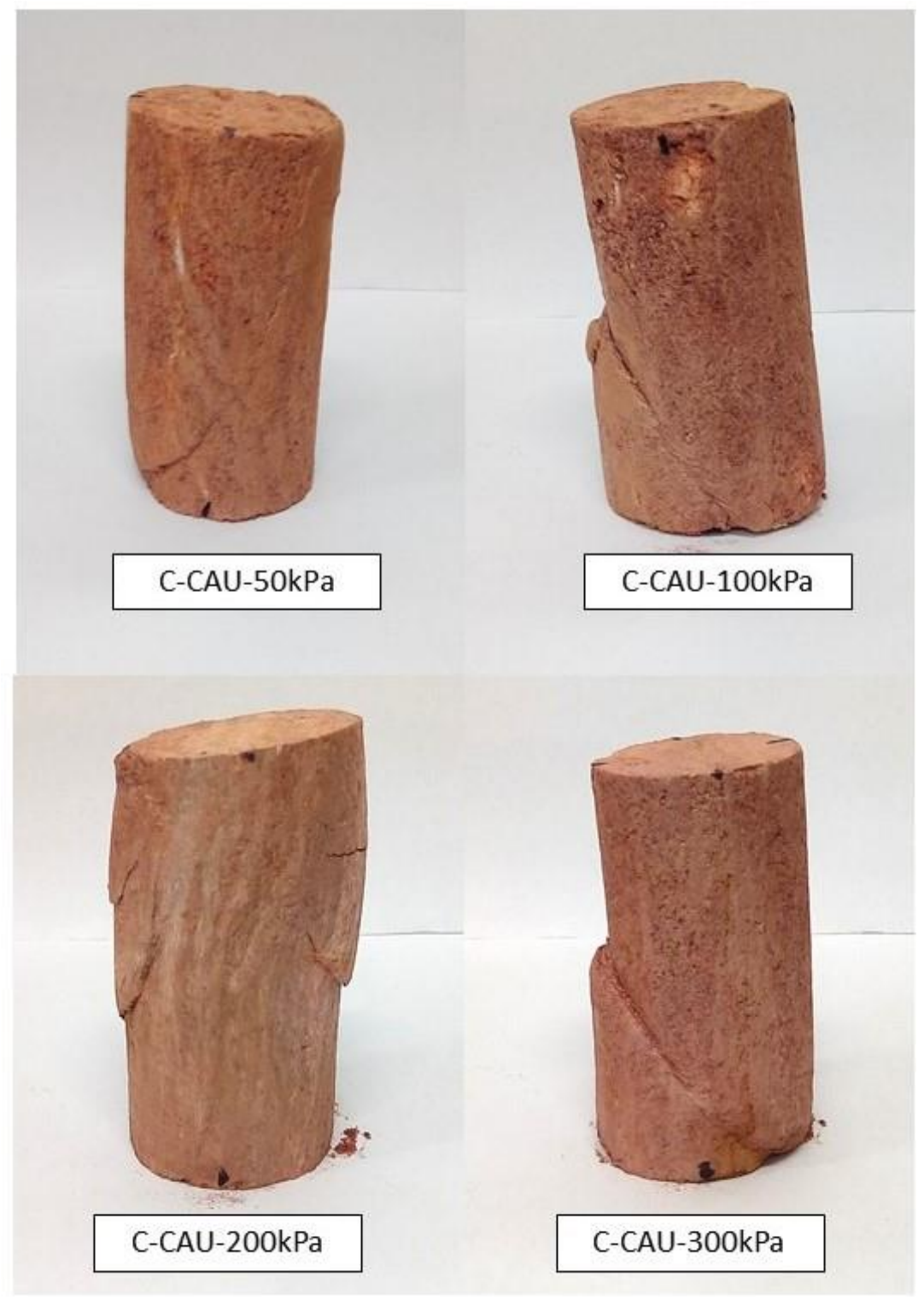

Figura 46. Resultados do ensaio D - corpos de prova ensaiados 

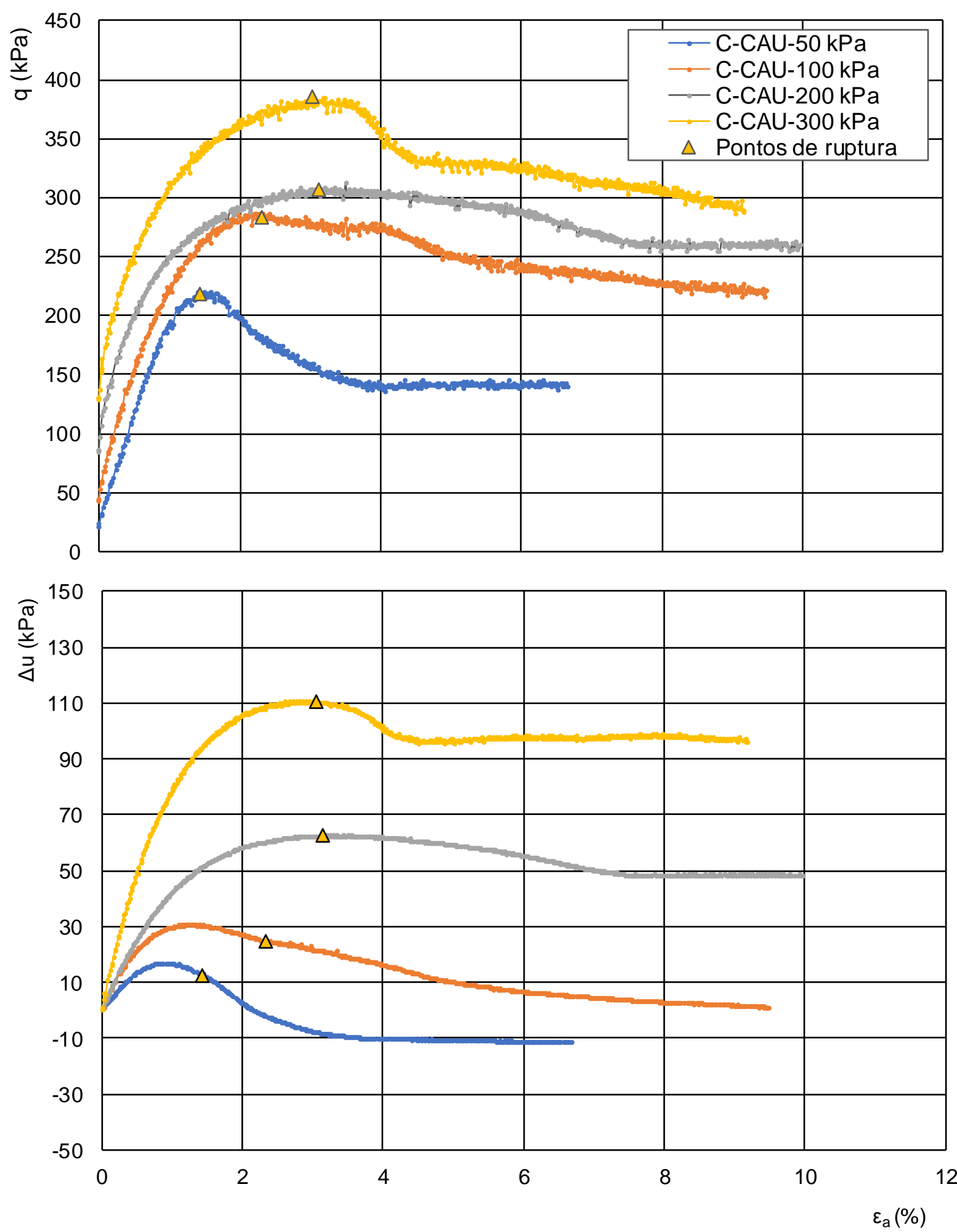

Figura 47. Resultados do ensaio D - curvas de tensão-deformação e variação de poropressões versus deformação axial

Como pode ser observado, os ensaios com tensões de adensamento de $50 \mathrm{kPa}$ e 300 $\mathrm{kPa}$ apresentaram um pico de resistência. No ensaio de $50 \mathrm{kPa}$, após a ruptura a tensão desviatória é estabilizada, após $4 \%$ de deformação. Já no ensaio realizado 
com confinante de $300 \mathrm{kPa}$, após a ruptura ocorre a tendência de queda da tensão desviatória, mesmo após deformações de 8\%. Em relação ao comportamento das poro-pressões, nos ensaios de 50 e $100 \mathrm{kPa}$, ocorre um pico de poro-pressões pouco antes da ruptura, após este pico a tensão, a poro-pressão é estabilizada em um patamar abaixo. Ocorre geração de poro-pressões negativas no ensaio de 50 kPa. Já nos ensaios de 200 e $300 \mathrm{kPa}$, há incremento de pressões neutras até a ruptura, em seguida as pressões se estabilizam num patamar abaixo da máxima.

As diferenças de comportamento dos ensaios podem estar associadas à elevada heterogeneidade do solo. Outra possível interpretação das diferenças ocorridas nos ensaios está associada à quebra de cimentação durante as fases de adensamento e cisalhamento.

De acordo com Pinto (2006), a quebra da cimentação dos corpos de prova pode ocorrer nas fases de cisalhamento ou na fase de adensamento, dependendo da pressão confinante efetiva aplicada. Quando a tensão de adensamento é muito menor que a tensão necessária para a quebra da cimentação (tensão de cedência), a curva tensão-deformação típica apresenta um pico de tensão até a total quebra da cimentação e, em seguida, é estabilizada na resistência residual, onde a resistência é dada pelo atrito do contato entre os grãos, como o ocorrido no ensaio realizado com tensão de $50 \mathrm{kPa}$.

Ainda de acordo com o autor, para uma tensão confinante mais alta, porém ainda menor que a tensão de cedência, após a quebra da cimentação ocorre um pequeno aumento da tensão desviatória, devido a mobilização da tensão ocorrida pelo atrito do contato entre os grãos. Este comportamento é observado no ensaio realizado com tensão de adensamento de $100 \mathrm{kPa}$, com aumento da resistência pós-pico, perto de $4,00 \%$ de deformação.

Para tensões de adensamento acima da tensão de cedência, o solo apresenta curva típica de solos não cimentados, já que a cimentação é destruída durante a fase de adensamento, como ocorre no ensaio de $200 \mathrm{kPa}$. A Figura 48 traz as curvas típicas para cada um desses casos, conforme Pinto (2006).

No ensaio realizado com tensão de adensamento de $300 \mathrm{kPa}$, o pico de tensão pode estar associado ao colapso da estrutura, onde a resistência gerada pelo contato entre os grãos é perdida e a tensão desviatória tende a cair no pós-pico. O mesmo 
comportamento é observado no ensaio de $300 \mathrm{kPa}$ do ensaio $\mathrm{E}$, visto adiante, cuja queda de resistência pós-pico é bem evidente.

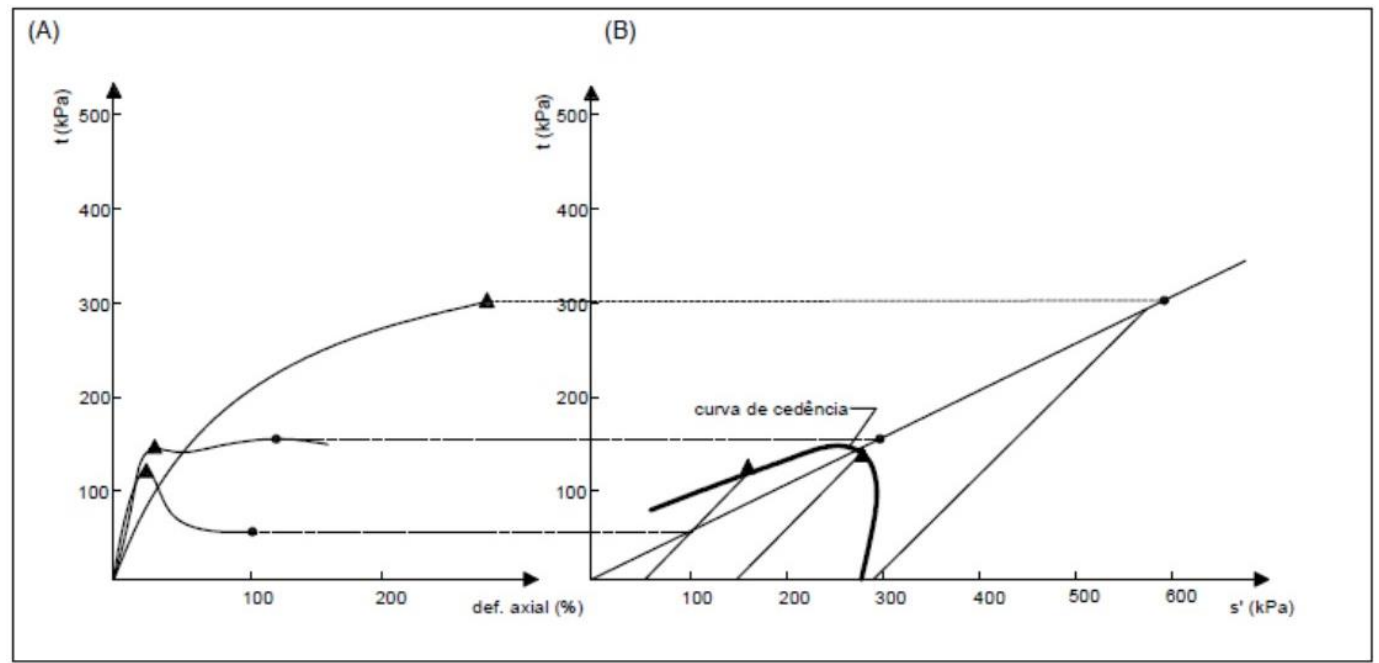

Figura 48. (a) Curvas de tensão-deformação com comportamentos distintos: em A, ensaio realizado com tensão de adensamento abaixo da tensão de cedência; em $B$, ensaio com tensão confinante próximo a tensão de cedência; em $C$, ensaio com confinante maior que a tensão de cedência. Em (b) trajetórias de tensão e definição da curva de cedência (adaptado de Pinto, 2006)

A Figura 49 e a Figura 50 trazem as trajetórias de tensão efetivas e os círculos de Mohr com a envoltória de ruptura interpretadas. Os parâmetros de resistência obtidos foram: $c^{\prime}=61 \mathrm{kPa}$ e $\varphi^{\prime}=20^{\circ}$.

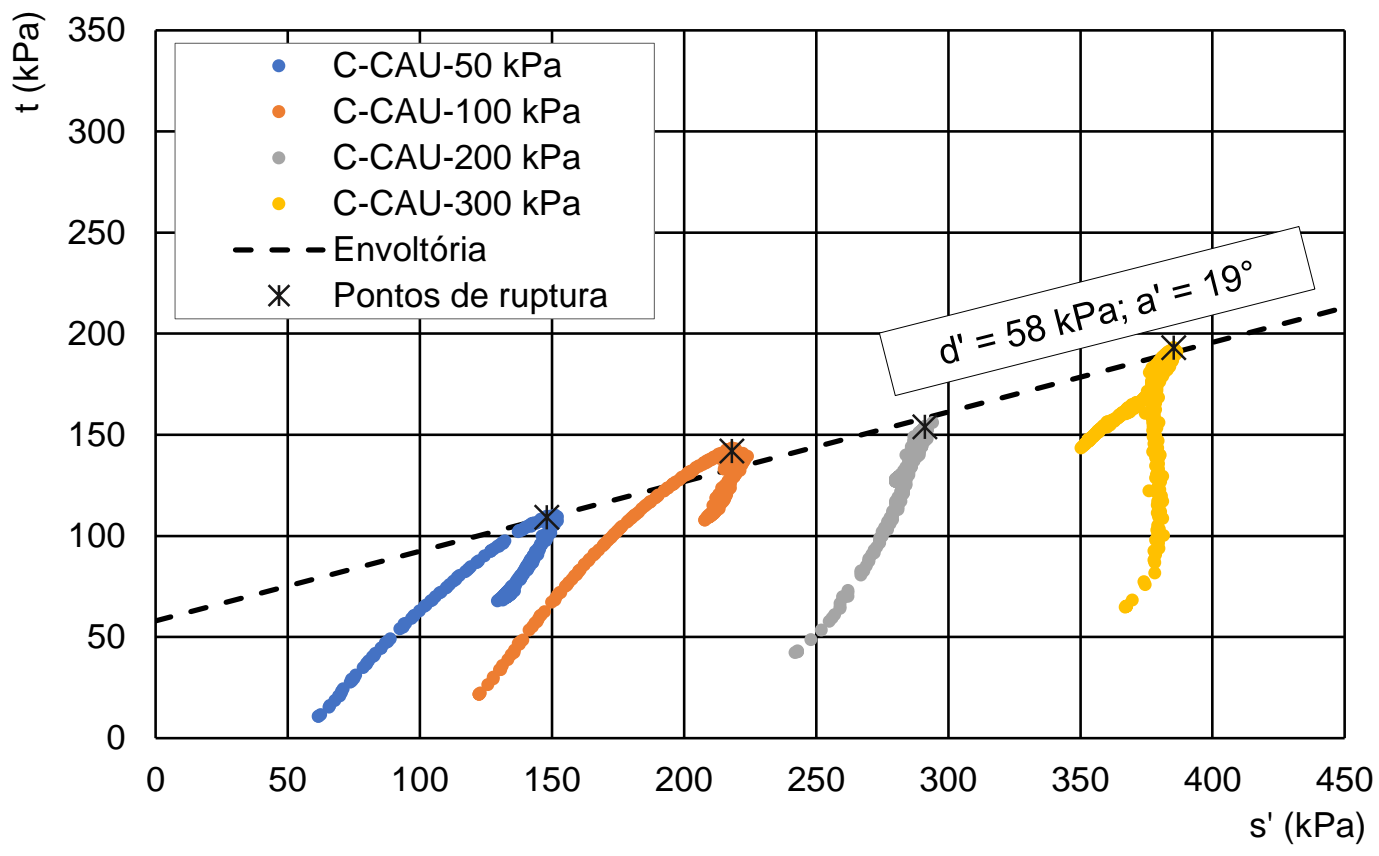

Figura 49. Resultados do ensaio D- trajetórias de tensões 


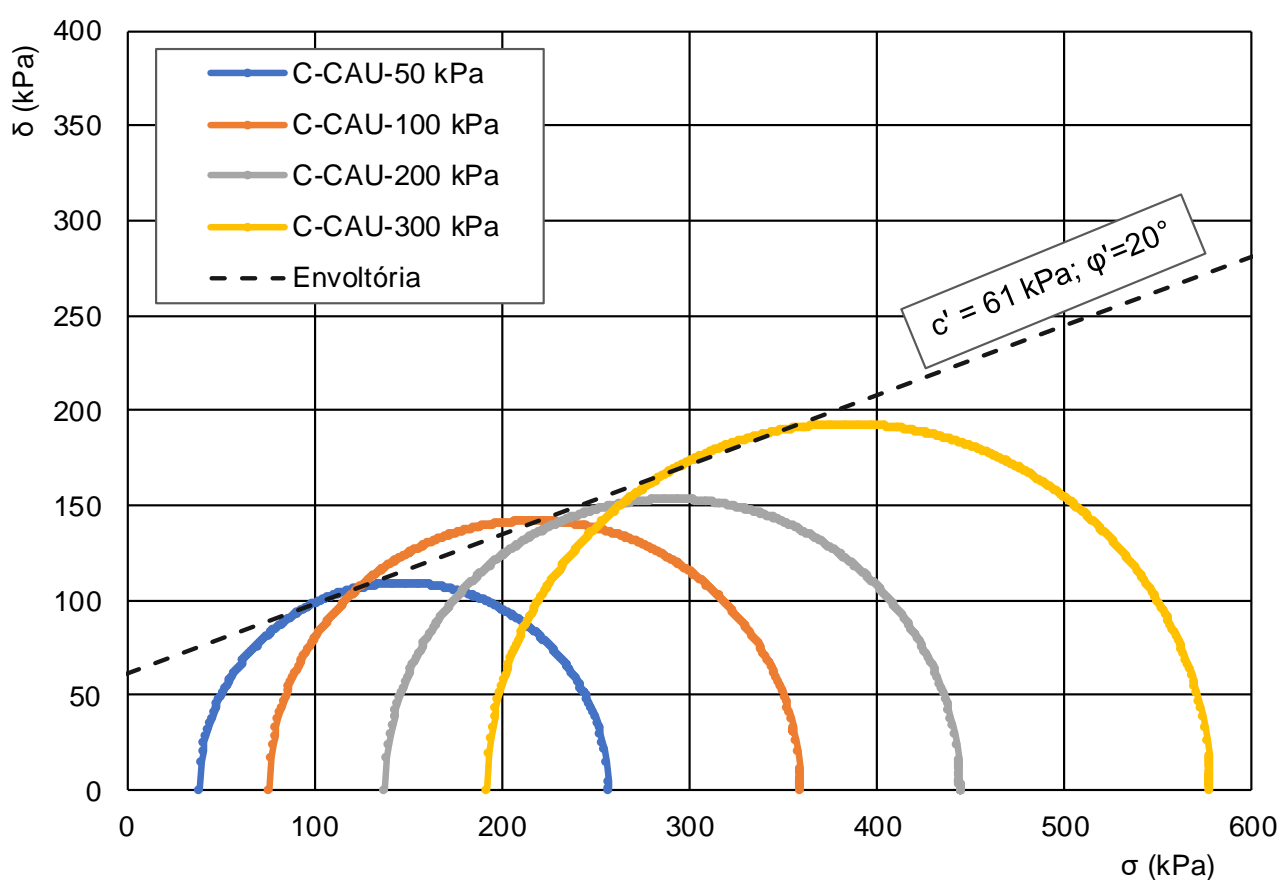

Figura 50. Resultados do ensaio D - círculos de Mohr e envoltória de ruptura interpretada

Embora o procedimento de medição dos deslocamentos durante o ensaio triaxial tenha sido feito utilizando medição externa, que incorpora deformações do sistema, o procedimento de adensamento anisotrópico minimiza este problema. Aliado ao cuidado na obtenção dos corpos de prova foi possível obter deformações da ordem de $0.01 \%$.

$\mathrm{Na}$ Figura 51 estão apresentados os valores dos módulos de deformabilidade secantes relacionados às deformações durante o processo de cisalhamento nos ensaios triaxiais. Observa-se que para baixos níveis de deformação há uma variação entre o comportamento dos módulos em função da tensão confinante. Para as tensões confinantes de $50 \mathrm{kPa}$ e $100 \mathrm{kPa}$ os módulos apresentam valores próximos até um nível de deformação da ordem de $0.5 \%$. A partir deste ponto há uma degradação do módulo. Já para as tensões confinantes de 200 kPa e 300 kPa, não se observa um patamar inicial constante e o módulo continuamente se reduz com a deformação do corpo de prova. Na Figura 52 é apresentado o módulo de deformabilidade normalizado pela tensão efetiva média ( $p$ '). Observa-se que não há uma tendência única com este tipo de normalização. Este aspecto pode ser devido a aspectos estruturais do solo e a sua variabilidade. 


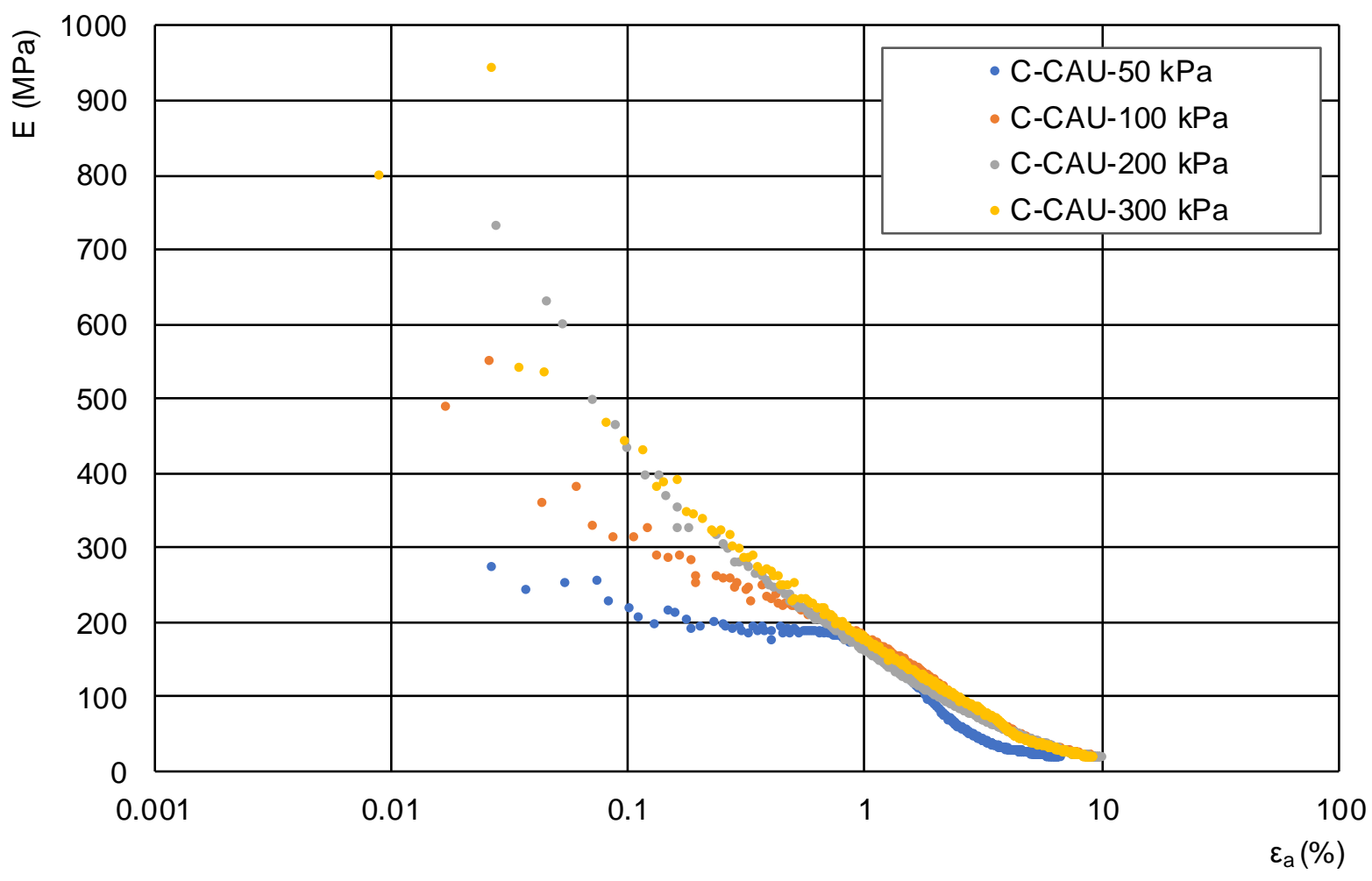

Figura 51. Resultados do ensaio D - módulos de deformação

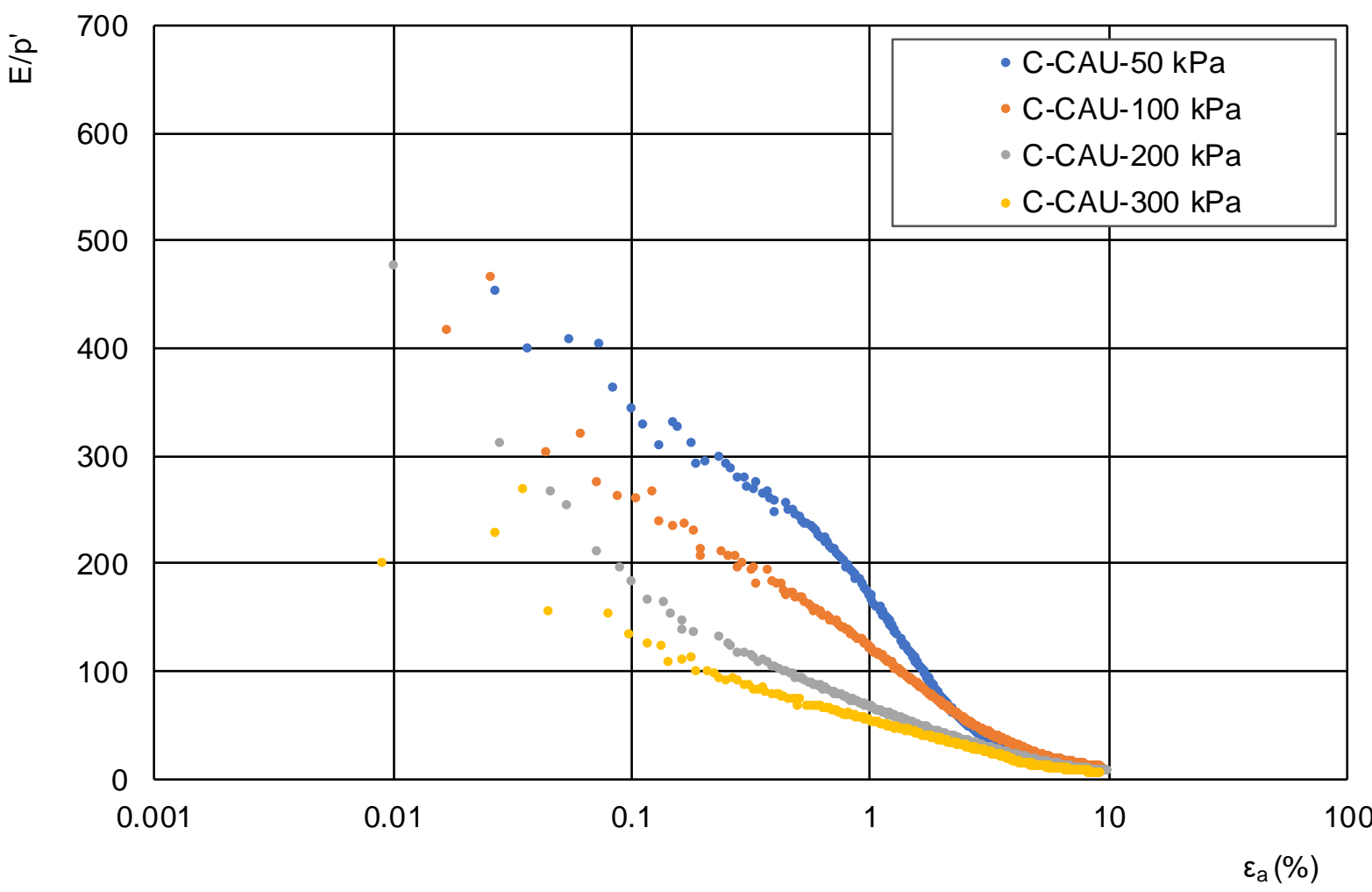

Figura 52. Resultados do ensaio D - módulos de deformabilidade normalizados pela tensão efetiva média 


\subsubsection{Ensaio E: C-CIU-100,200 e $300 \mathrm{kPa}$}

Devido a elevada heterogeneidade do solo, foi realizado um outro ensaio triaxial convencional com corpos de provas retirados a partir do bloco $\mathrm{C}$ (ensaio $\mathrm{E}$ ). Foram realizados ensaios do tipo CIU, com tensões de adensamento de 100, 200 e $300 \mathrm{kPa}$. A Figura 53 apresenta as fotos dos corpos de prova após o ensaio e a Tabela 9 traz as características iniciais dos cp's.

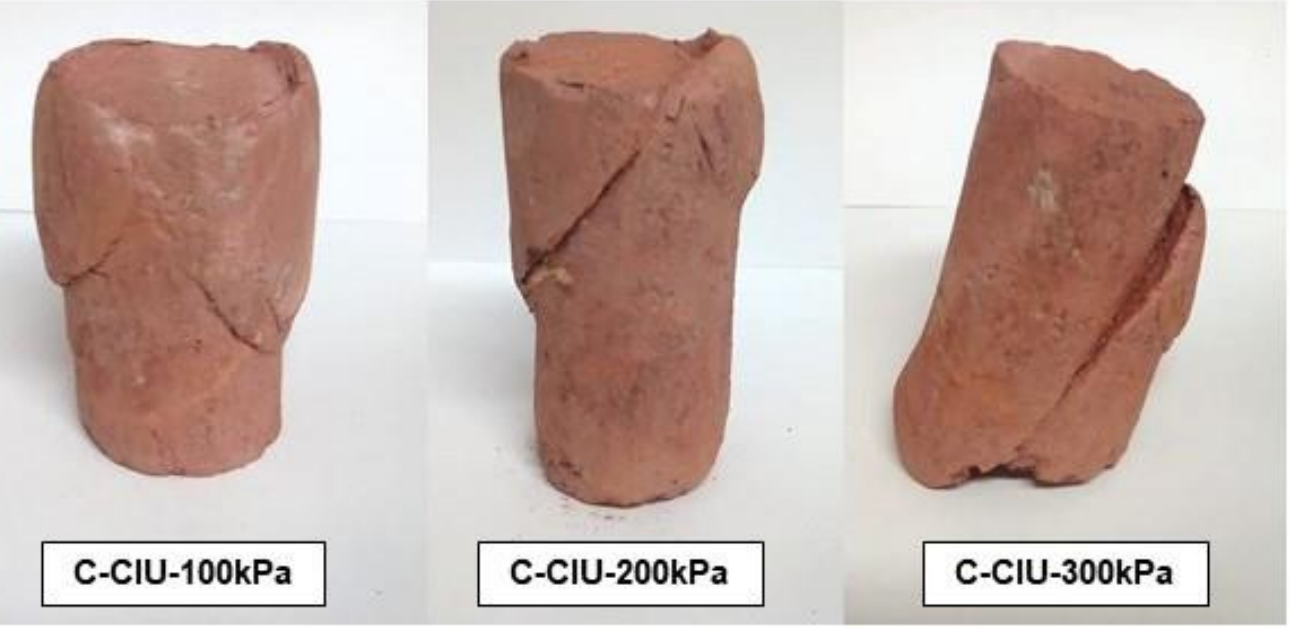

Figura 53. Resultados do ensaio E - corpos de prova cisalhados

Tabela 9. Resultados do ensaio E - características iniciais dos corpos de prova ensaiados

\begin{tabular}{|c|c|c|c|c|}
\hline \multirow{2}{*}{\begin{tabular}{|l} 
ID \\
ENSAIO \\
\end{tabular}} & & \multicolumn{3}{|c|}{$\mathbf{E}$} \\
\hline & & $\mathrm{C}-\mathrm{ClU}-100 \mathrm{kPa}$ & C-ClU-200 kPa & C-CIU-300 kPa \\
\hline umidade inicial & $\%$ & 21.15 & 21.05 & 23.49 \\
\hline Área da seção & $\mathrm{cm}^{2}$ & 9.75 & 11.40 & 12.03 \\
\hline Volume & $\mathrm{cm}^{3}$ & 79.80 & 88.93 & 106.27 \\
\hline Peso úmido & $\mathrm{g}$ & 135.54 & 154.78 & 172.46 \\
\hline Peso seco & g & 111.87 & 127.86 & 139.66 \\
\hline Densidade úmida & $\mathrm{g} / \mathrm{cm}^{3}$ & 1.70 & 1.74 & 1.62 \\
\hline Densidade seca & $\mathrm{g} / \mathrm{cm}^{3}$ & 1.40 & 1.44 & 1.31 \\
\hline índice de vazios & & 0.93 & 0.88 & 1.06 \\
\hline S inicial & $\%$ & 61.44 & 64.48 & 59.93 \\
\hline Umidade após aspersão & $\%$ & 31.67 & 31.55 & 33.68 \\
\hline
\end{tabular}

A Figura 54 traz os gráficos de tensão-deformação e variação de poro-pressões. Como pode ser observado, o ensaio realizado com $100 \mathrm{kPa}$ de confinante apresenta um pico de resistência, após a ruptura a tensão desviatória decresce e não é estabilizada. No ensaio de $200 \mathrm{kPa}$ não há pico de resistência e a tensão tende a decrescer lentamente após a ruptura. No ensaio de $300 \mathrm{kPa}$, após a ruptura ocorre um decréscimo abrupto da tensão desviatória, apresentando um comportamento típico de solos colapsáveis. 
Em relação ao comportamento das poro-pressões, observa-se que os ensaios de 100 e $200 \mathrm{kPa}$ apresentaram um pico de poro-pressão anterior a ruptura. Já o ensaio de $300 \mathrm{kPa}$, ocorreu aumento da poro-pressão após o pico de tensão.

Como discutido no ensaio $D$, tais diferenças de comportamento podem ser causadas pela heterogeneidade típica do material ou pela quebra de cimentação nas fases de adensamento. Possivelmente, no ensaio de $100 \mathrm{kPa}$, ainda há influência da cimentação na resistência da amostra. No ensaio de $200 \mathrm{kPa}$, é provável que a cimentação da amostra seja quebrada durante a fase de adensamento do ensaio e a curva de resistência da amostra seja ditada apenas pelo atrito do contato entre os grãos. No ensaio de $300 \mathrm{kPa}$, o pico de tensão pode estar associado ao colapso da estrutura da amostra, onde o contato entre os grãos é perdido e a tensão desviatória tende a cair bruscamente.

Como ocorrido no ensaio $D$, a quebra da cimentação no adensamento parece ocorrer entre 200 e $300 \mathrm{kPa}$.

A Figura 55 traz o gráfico de tensão-deformação normalizado pela tensão confinante efetiva. Como pode ser visualizado na figura, o pico da tensão normalizada ocorre anteriormente à ruptura interpretada. Os pontos de ruptura foram determinados pelas curvas de tensão-deformação presentes na Figura 54. 

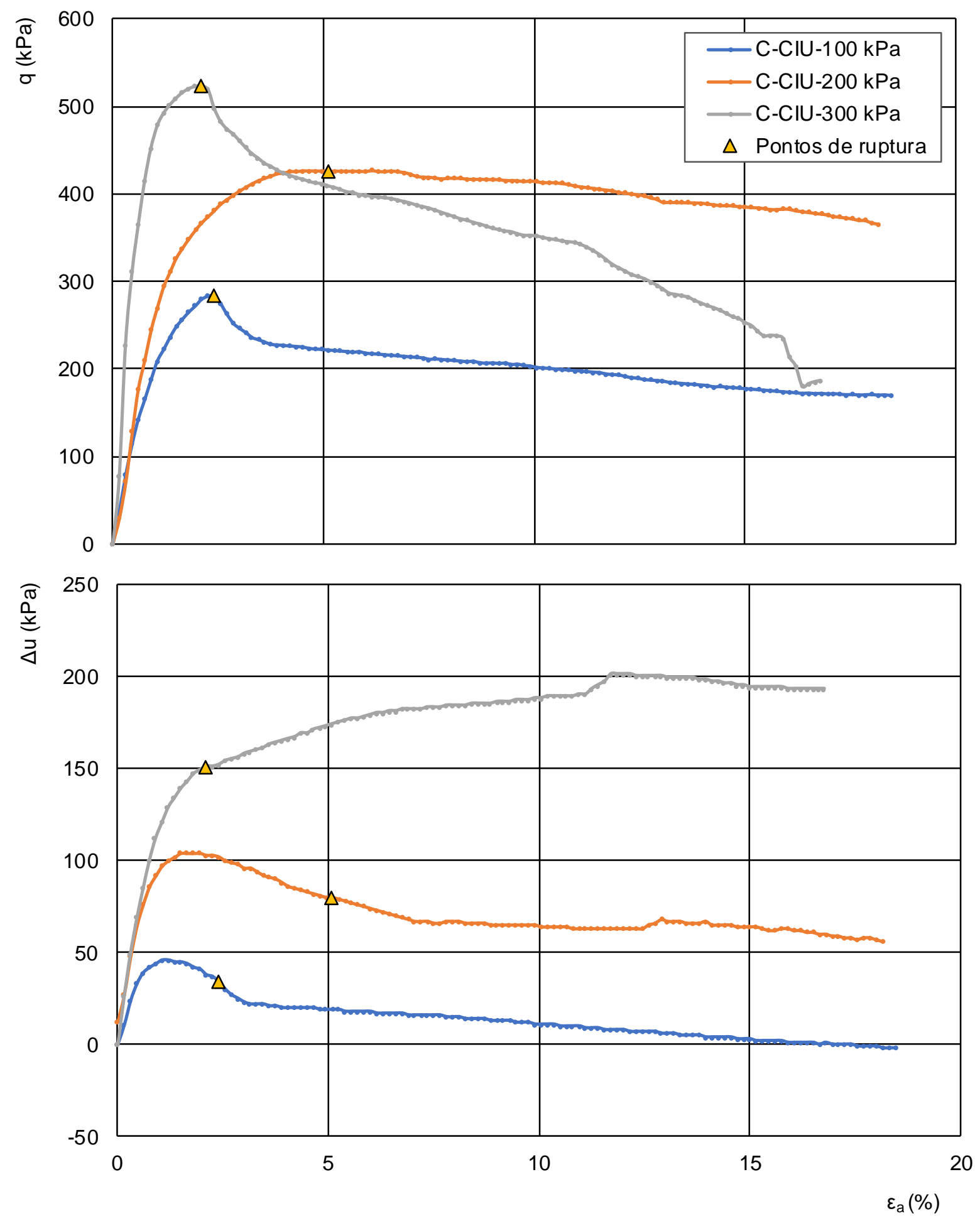

Figura 54. Resultados do ensaio E - curva de tensão-deformação e variação de poro-pressão versus deformação axial 


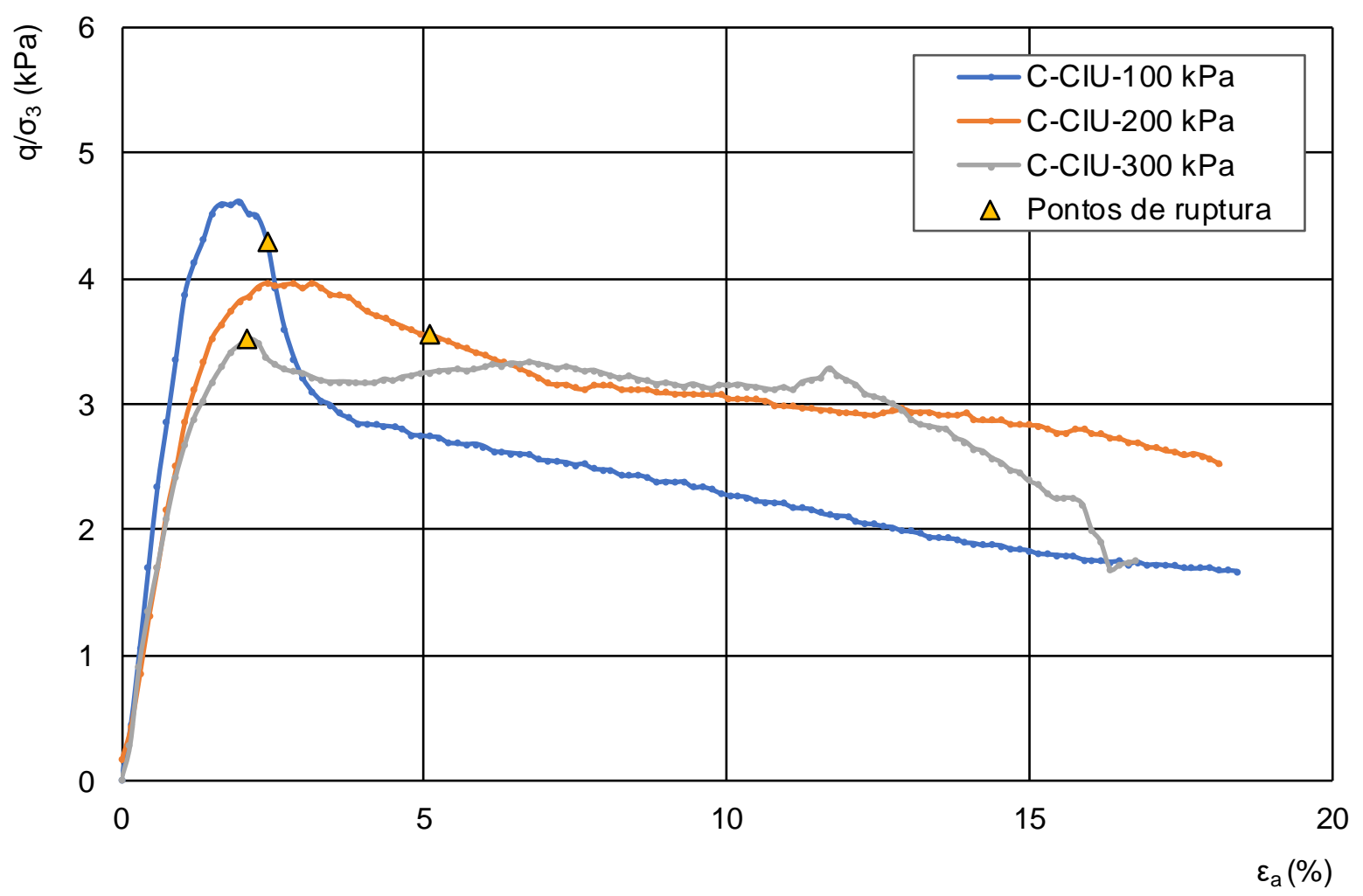

Figura 55. Resultados do ensaio E - curvas de tensão-deformação normalizados pela tensão confinante efetiva

A Figura 56 apresenta as trajetórias de tensões efetivas obtidas com a envoltória de ruptura interpretada. Os parâmetros de resistência obtidos foram: $\mathrm{c}^{\prime}=29 \mathrm{kPa}$ e $\varphi^{\prime}=$ $35^{\circ}$.

A Figura 57 apresenta os círculos de Mohr obtidos com a envoltória de ruptura. As Figura 58 e a Figura 59 trazem, respectivamente, os módulos de deformação e os módulos de deformações normalizados por p'. 


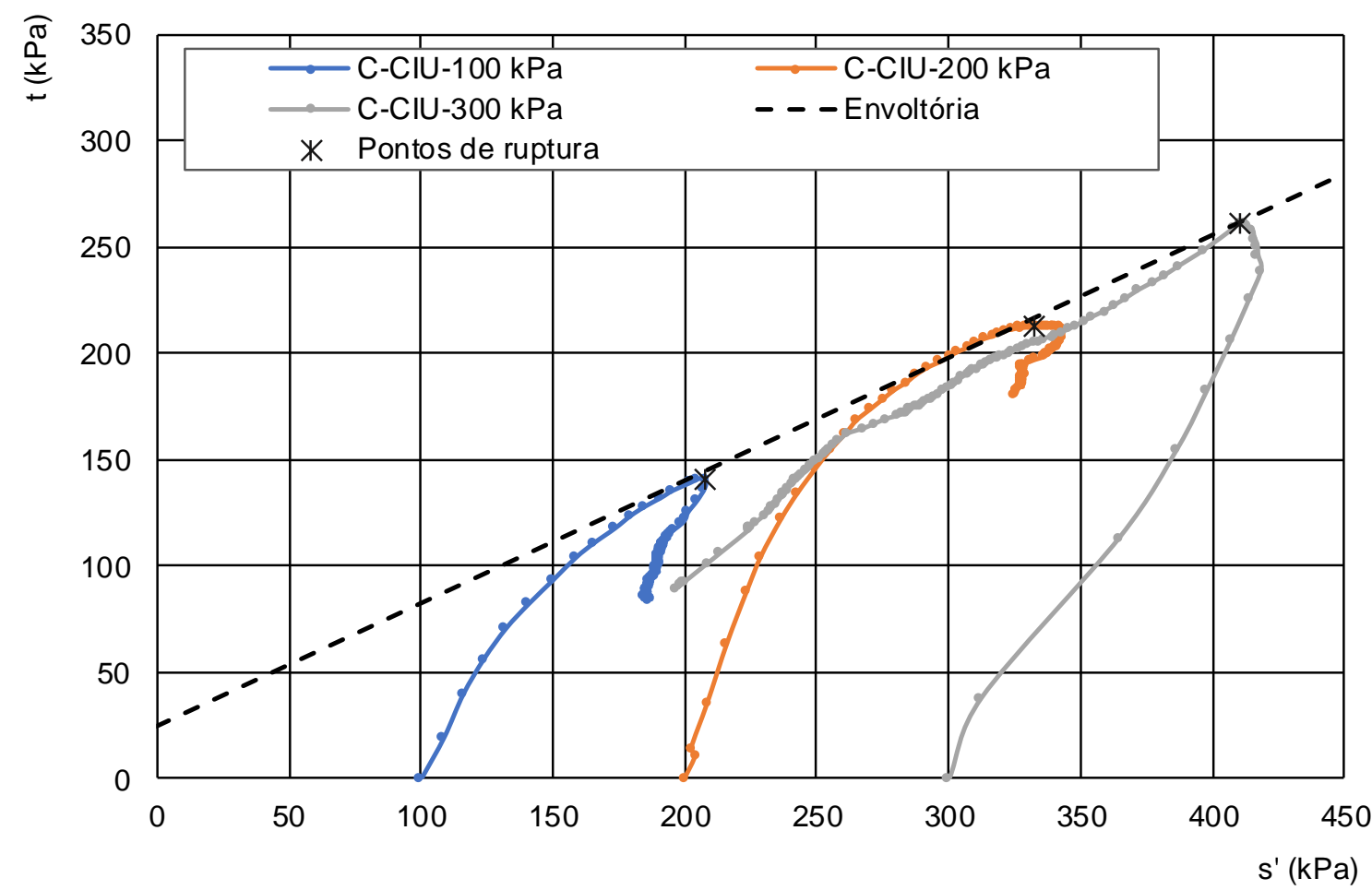

Figura 56. Resultados do ensaio E - trajetórias de tensões e envoltórias de ruptura interpretadas

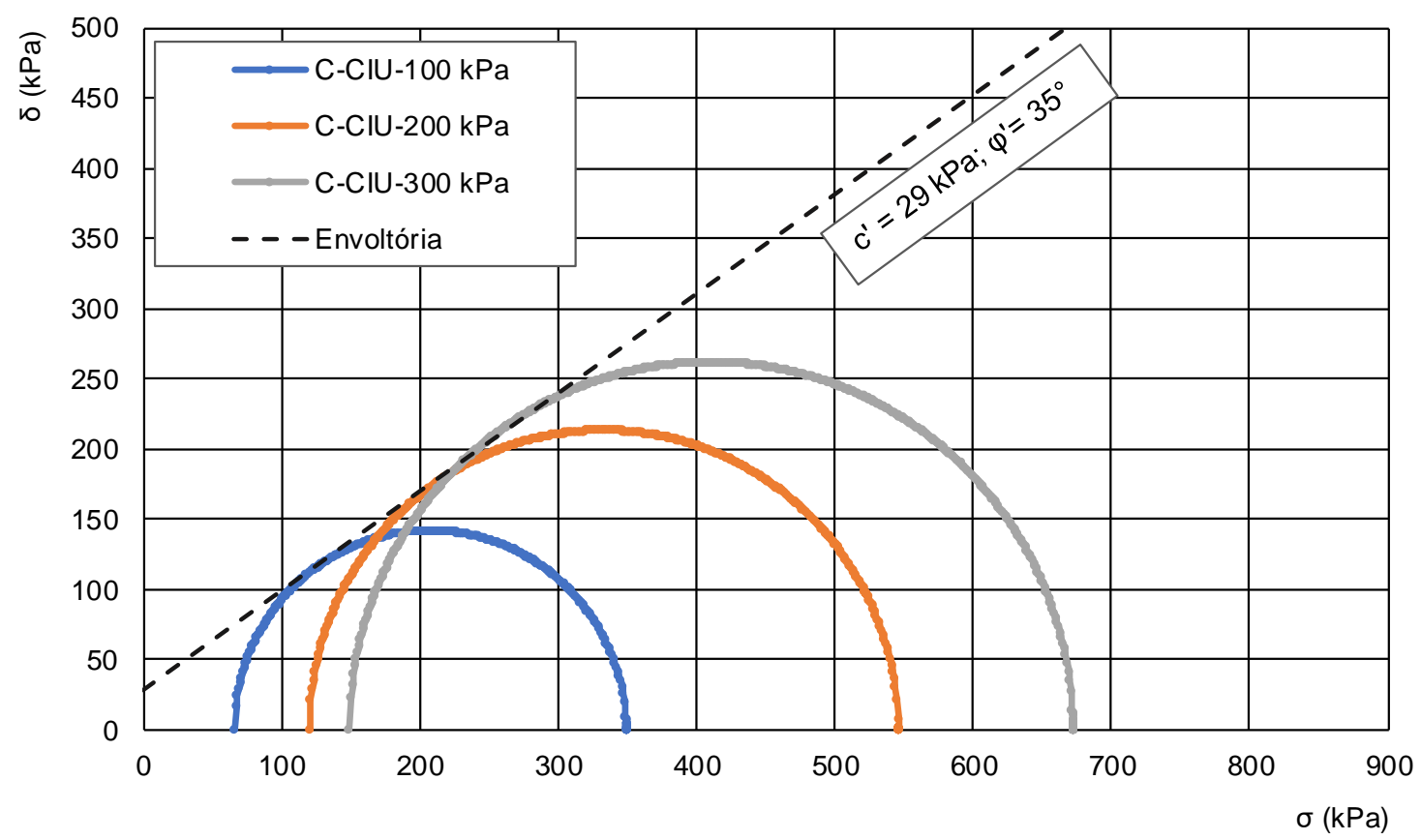

Figura 57. Resultados do ensaio E - círculos de Mohr e envoltória de ruptura interpretada 


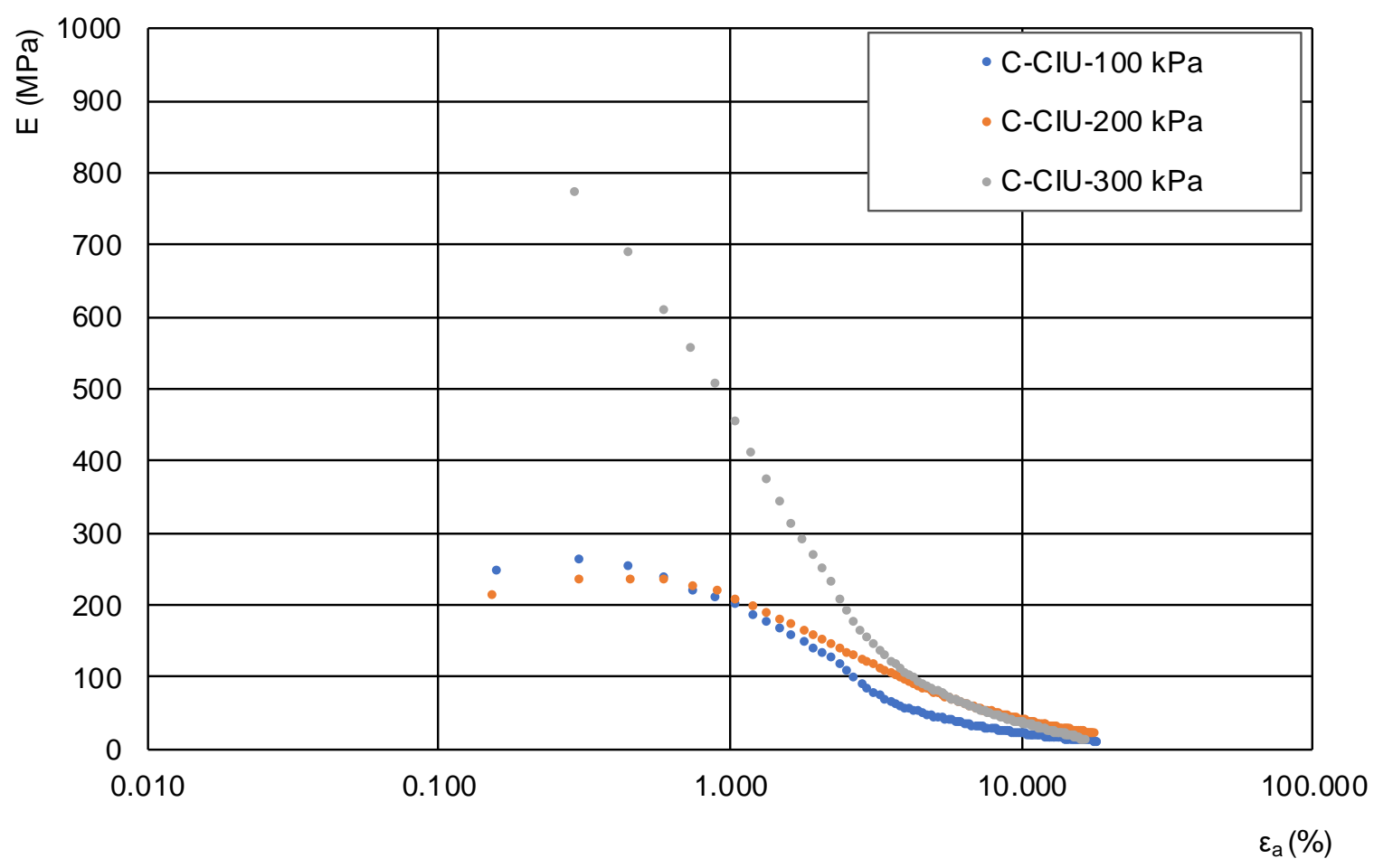

Figura 58. Resultados do ensaio E - módulos de deformação

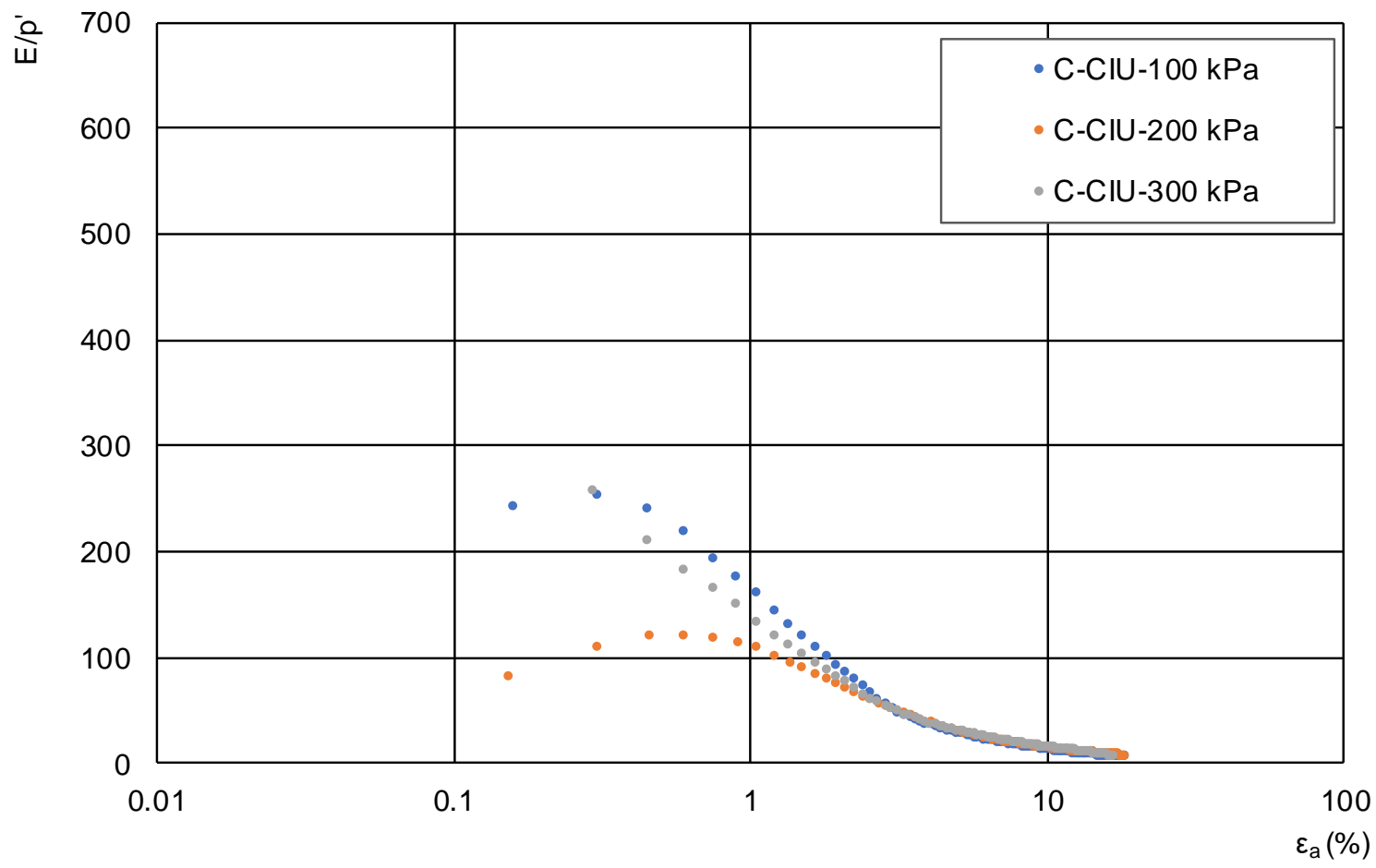

Figura 59. Resultados do ensaio E - módulos de deformação normalizados pela tensão efetiva média ( $\left.p^{\prime}\right)$ 


\subsubsection{Ensaios triaxiais multi-estágio em amostras indeformadas}

\subsubsection{Ensaio F: ME-CAU-50,100,200 kPa}

Foram realizados ensaios triaxiais multi-estágio do tipo CAU com tensões de adensamento de 50, 100 e $200 \mathrm{kPa}$ em uma amostra indeformada (ensaio F). A Tabela 10 traz as características iniciais do corpo de prova.

A Figura 60 traz fotos do corpo de prova utilizado durante a moldagem e a

Figura 61 traz o corpo de prova em ângulos distintos. Como indicado, no corpo de prova utilizado havia bolsões de um material poroso de coloração marrom escura. Este material, durante a primeira fase de adensamento, não resistiu à compressão e entrou em colapso, como ilustrado na Figura 60. ABEF (1989) relatou a presença deste material neste solo e descreveu o mesmo comportamento durante a fase de adensamento.

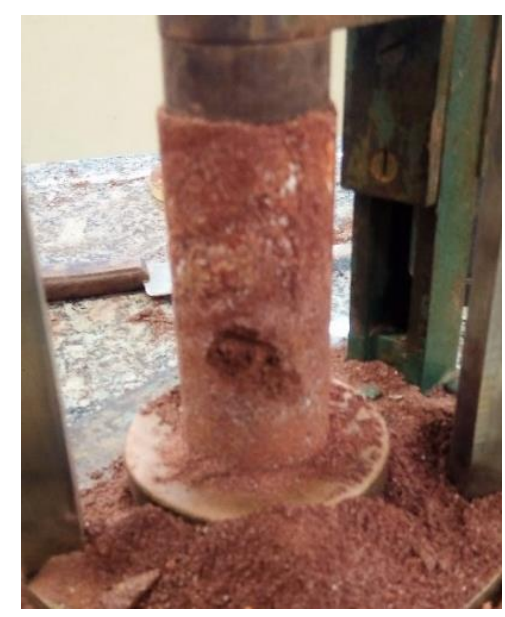

Figura 60. Corpo de prova utilizado no ensaio $\mathrm{F}$ durante moldagem, ilustrando material poroso de coloração marrom escura no centro da amostra

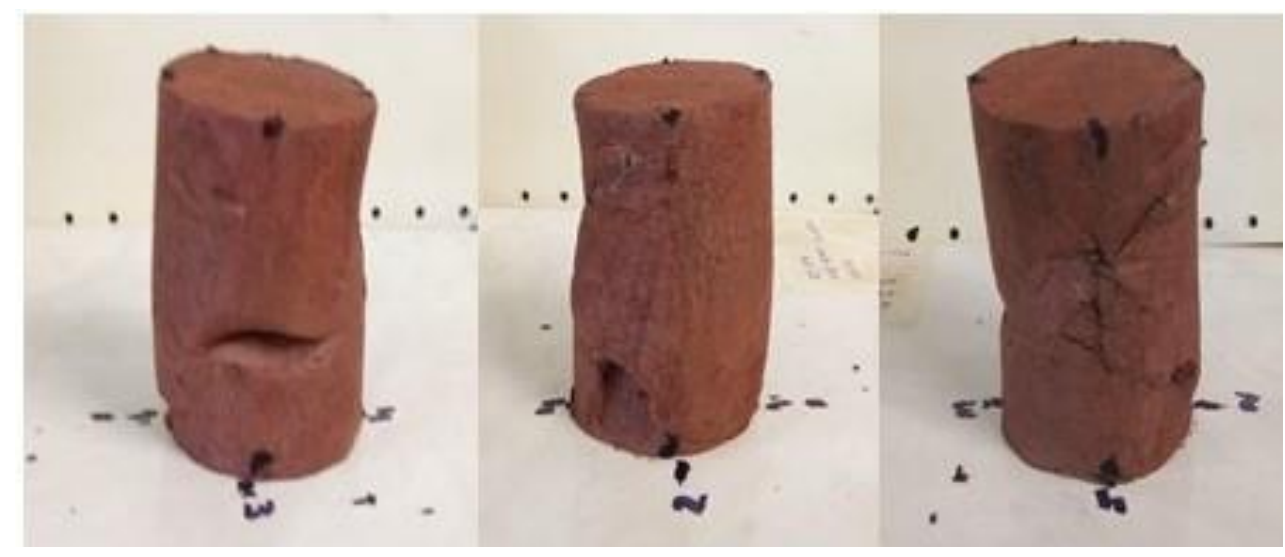


Figura 61. Corpo de prova utilizado no ensaio $F$ após ensaio de cisalhamento triaxial, com cavidades geradas pelo colapso dos bolsões porosos durante compressão

Tabela 10. Resultados do ensaio F - características iniciais do corpo de prova utilizado

\begin{tabular}{|lr|c|}
\hline ID & \multicolumn{1}{|c|}{$\mathbf{F}$} \\
\hline ENSAIO & $\begin{array}{r}\text { ME-CAU-50,100,200 } \\
\text { kPa }\end{array}$ \\
\hline umidade inicial & $\%$ & 19.36 \\
\hline Área da seção & $\mathrm{cm}^{2}$ & 11.38 \\
\hline Volume & $\mathrm{cm}^{3}$ & 88.89 \\
\hline Peso úmido & $\mathrm{g}$ & 158.95 \\
\hline Peso seco & $\mathrm{g}$ & 133.17 \\
\hline Densidade úmida & $\mathrm{g} / \mathrm{cm}^{3}$ & 1.79 \\
\hline Densidade seca & 1.50 \\
\hline índice de vazios & $\%$ & 0.81 \\
\hline S inicial & $\%$ & 64.87 \\
\hline Umidade após aspersão & 26.40 \\
\hline
\end{tabular}

Todos os corpos de prova foram adensados anisotropicamente, com uma relação entre tensão confinante e tensão axial igual a 0,7. Os gráficos de tensão-deformação e variação de poro-pressão versus deformação axial estão apresentados na Figura 62.

Observa-se que no ensaio de 200 kPa, a tensão de ruptura decresce após o pico de resistência, tendendo a se estabilizar após 7\% de deformação. Nos três ensaios, há elevação das poro-pressões até a ruptura. No último estágio, após a ruptura não ocorre estabilização das pressões neutras, que se elevam consideravelmente.

A Figura 63 traz os gráficos de tensão-deformação normalizados pelas tensões confinantes efetivas $\left(\sigma_{3}{ }^{\prime}\right)$. No gráfico normalizado observa-se que há tendência de estabilização da tensão após ruptura, numa tensão próxima da máxima atingida.

A Figura 64 e a

Figura 65 apresentam o diagrama de tensões e os círculos de Mohr de ruptura, respectivamente. Vê-se que, no ensaio de $200 \mathrm{kPa}$, o diagrama de tensões segue a envoltória de ruptura. Os parâmetros de resistência interpretados foram c'=12 kPa e $\varphi^{\prime}=21^{\circ}$. Os parâmetros obtidos são diferentes aos obtidos nos ensaios convencionais, porém o resultado é compatível aos resultados de Vieira (1999).

A 
Figura 66 e Figura 67 trazem os módulos de deformabilidade e os módulos normalizados por p', respectivamente. Há tendência de aproximação dos valores dos módulos de deformabilidade dos três estágios após $0,5 \%$ de deformação.

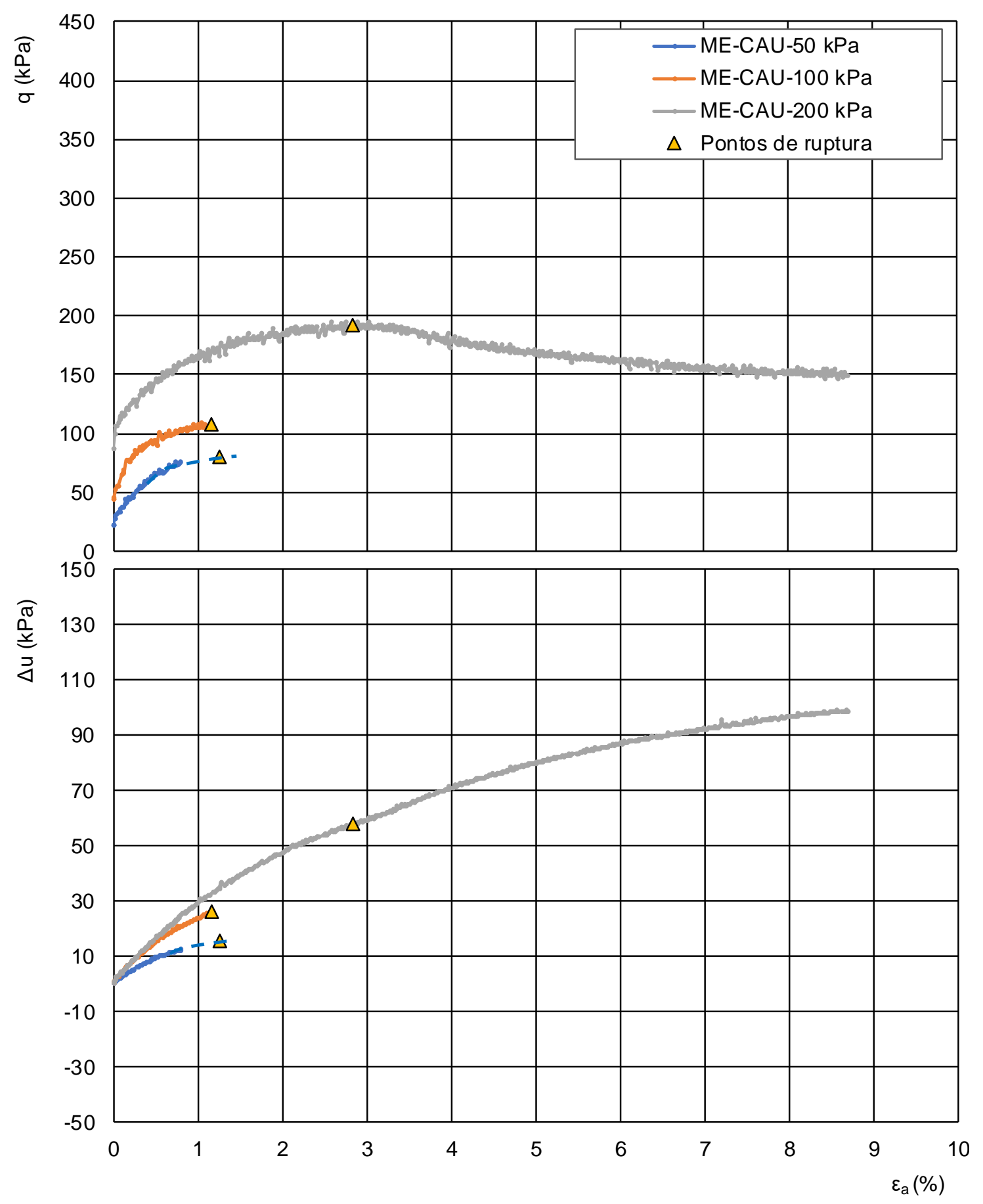

Figura 62. Resultados do ensaio F - gráficos de tensão-deformação e de variação de poropressões versus deformação axial 


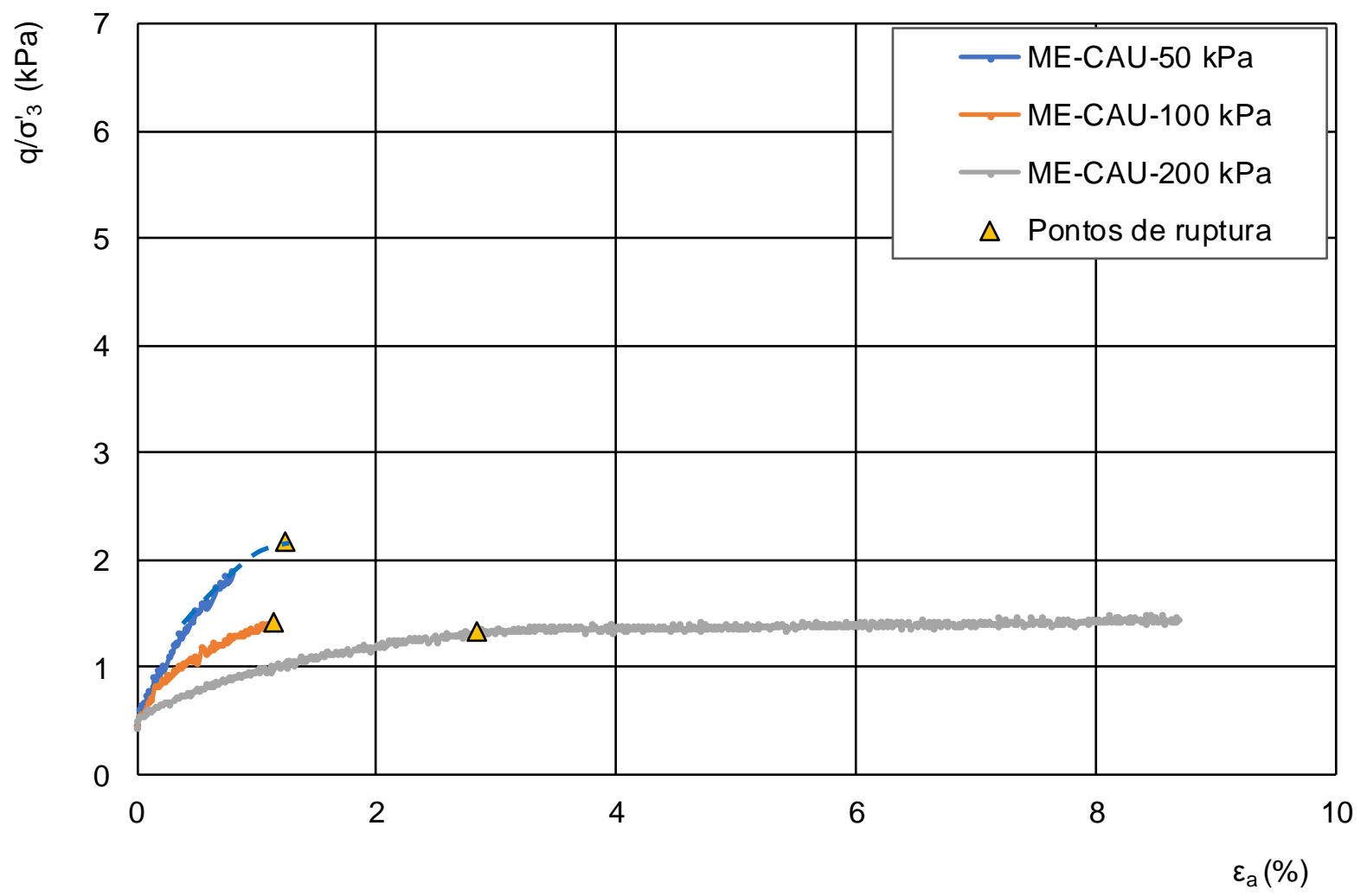

Figura 63. Resultados do ensaio F - gráfico de tensão-deformação normalizado pela tensão confinante efetiva

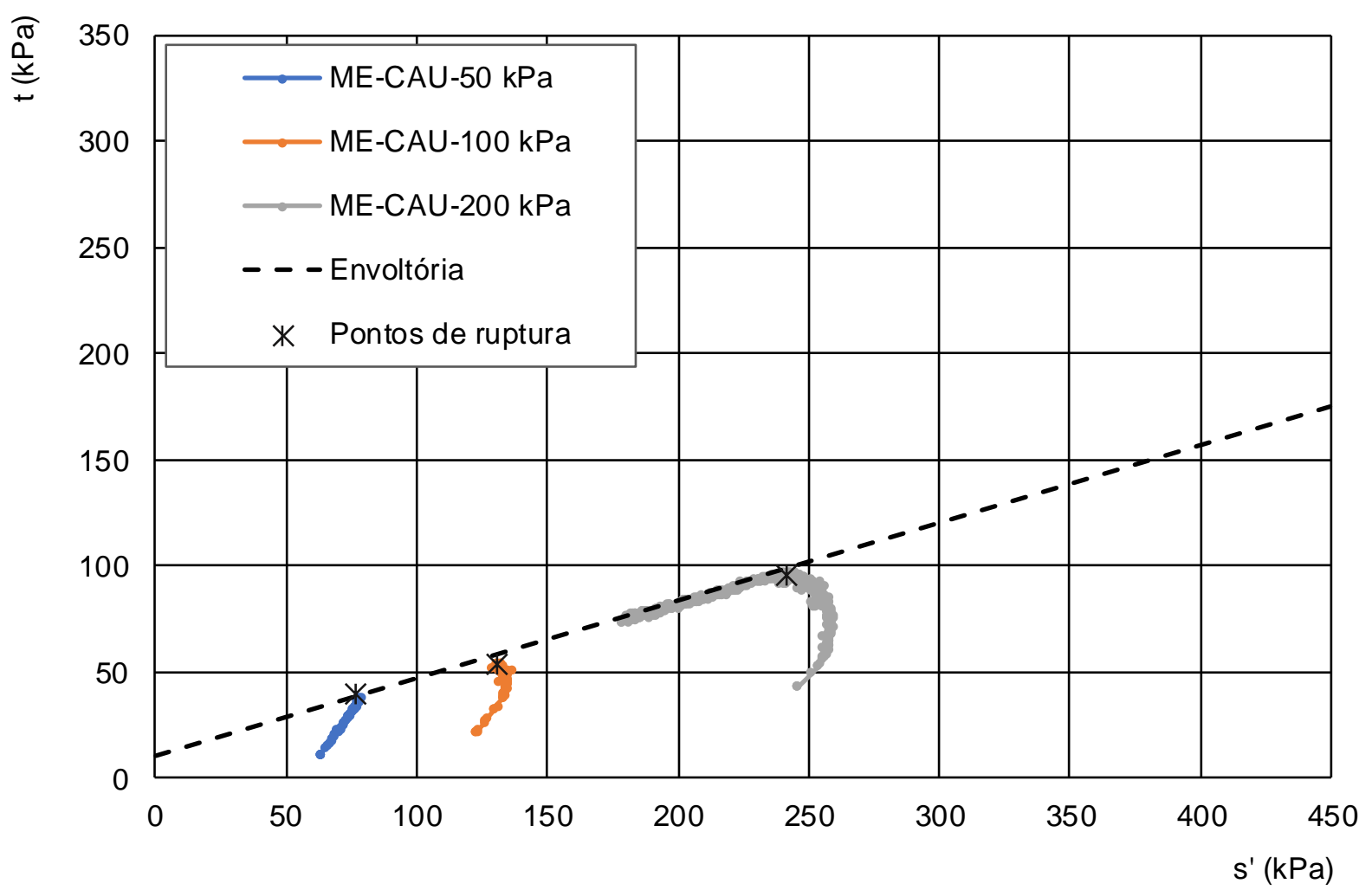

Figura 64. Resultados do ensaio F - diagrama de tensões com envoltória de ruptura interpretada 


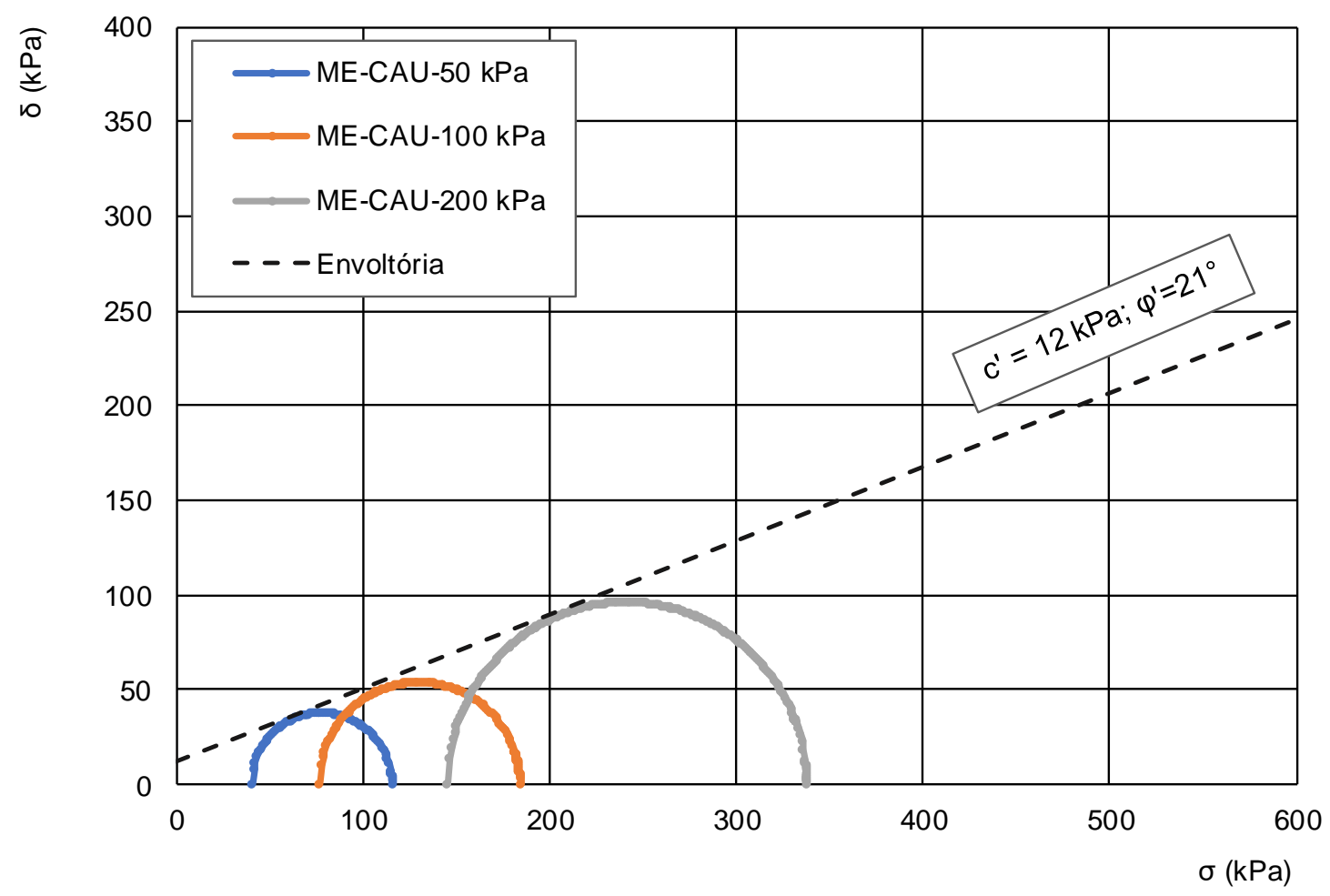

Figura 65. Resultados do ensaio F - círculos de Mohr e envoltória de ruptura

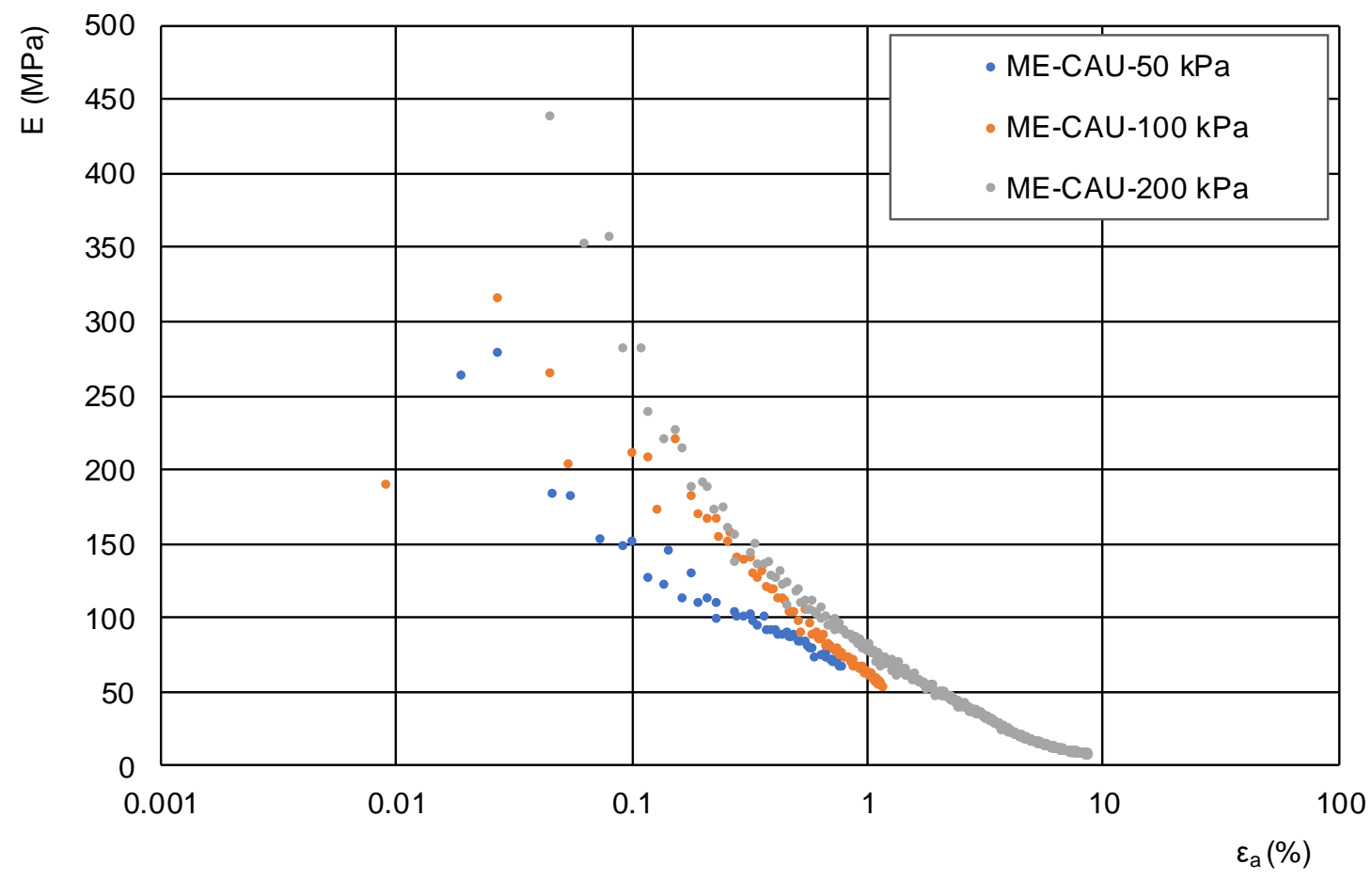

Figura 66. Resultados do ensaio F - módulos de deformação 


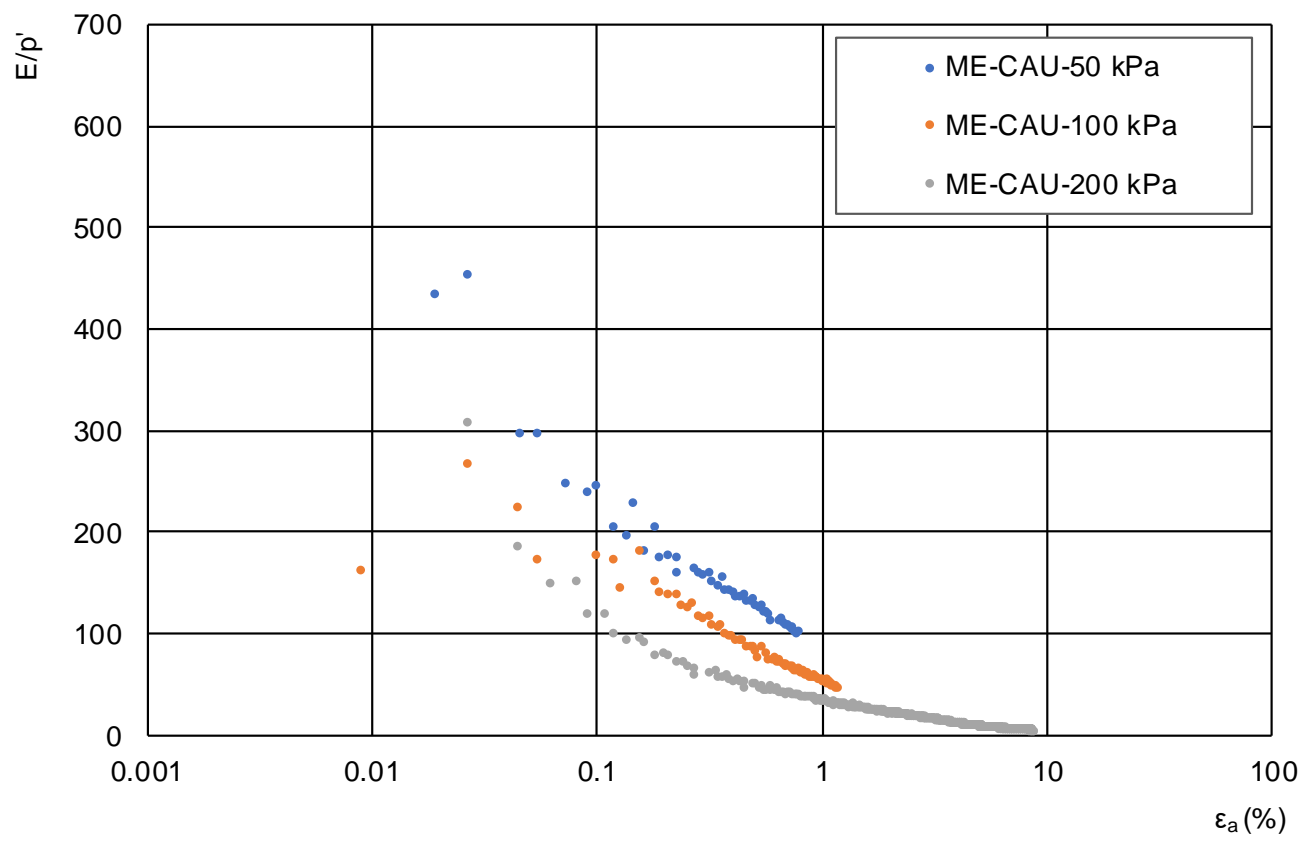

Figura 67. Resultados do ensaio F - módulos de deformação normalizado pela tensão efetiva média ( $p$ ')

\subsubsection{Ensaio G: ME-CAU-50,100 kPa}

Com o objetivo de realizar imagens microscópicas numa amostra que foi levada até o limiar o da ruptura, realizou-se um ensaio multi-estágio do tipo CAU, com tensões de adensamento de 50 e $100 \mathrm{kPa}$ (ensaio G). A Tabela 11 apresenta as características iniciais e a imagem do corpo de prova após cisalhamento, onde observa-se nesta escala, que não há formação aparente de plano de ruptura.

Tabela 11. Resultados do ensaio G - características iniciais e corpo de prova após cisalhamento

\begin{tabular}{|lr|r|}
\hline ID & \multicolumn{1}{|c|}{ G } \\
\hline ENSAIO & & ME-CAU-50,100 kPa \\
\hline umidade inicial & $\%$ & 20.72 \\
\hline Área da seção & $\mathrm{cm}^{2}$ & 11.08 \\
\hline Volume & $\mathrm{cm}^{3}$ & 91.58 \\
\hline Peso úmido & $\mathrm{g}$ & 152.72 \\
\hline Peso seco & $\mathrm{g}$ & 126.51 \\
\hline Densidade úmida & $\mathrm{g} / \mathrm{cm}^{3}$ & 1.67 \\
\hline Densidade seca & $\mathrm{g} / \mathrm{cm}^{3}$ & 1.38 \\
\hline índice de vazios & & 0.96 \\
\hline S inicial & $\%$ & 58.37 \\
\hline Umidade após aspersão & $\%$ & 30.10 \\
\hline
\end{tabular}


O ensaio foi paralisado no limiar da ruptura no estágio de cisalhamento, realizado com tensão de adensamento de $100 \mathrm{kPa}$ e, posteriormente, foi adensado até $200 \mathrm{kPa}$. A Figura 68 traz a trajetória de tensões do ensaio, mostrando as fases de adensamento, carregamento e descarregamento axial e o ponto de finalização do ensaio. Como pode ser visualizado na figura da Tabela 11 não ocorreu formação de plano de ruptura evidente em escala macroscópica.

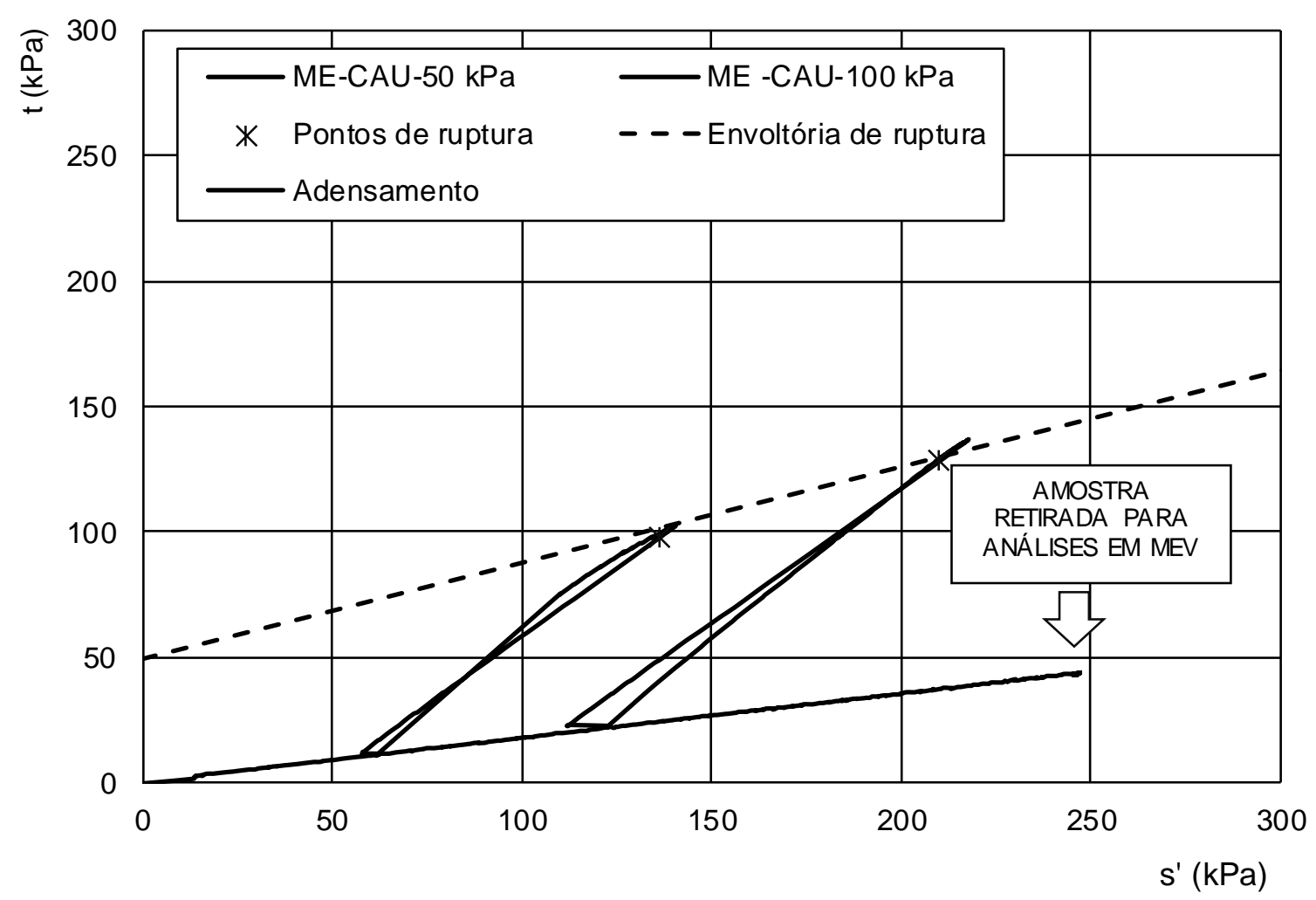

Figura 68. Resultados do ensaio G - trajetórias de tensões indicando o ponto de paralisação do ensaio

A Figura 69 traz os gráficos de tensão-deformação e de variação de poro-pressões versus deformação axial. O ponto de ruptura do ensaio realizado com tensão de adensamento de $100 \mathrm{kPa}$ foi interpretado de acordo com o comportamento do solo no ensaio A. No primeiro estágio de cisalhamento ocorre um pico de poro-pressão antes da ruptura, próximo a $0.5 \%$ de deformação. No segundo estágio a poro-pressão é crescente até a interrupção do cisalhamento. A Figura 70 traz as curvas de tensãodeformação normalizadas por $\sigma_{3}$ '.

Na Figura 71 e na Figura 72 estão apresentados as trajetórias de tensão e os círculos de Mohr obtidos, com indicação da envoltória de ruptura interpretada. Os parâmetros de resistência interpretados foram: $\mathrm{c}^{\prime}=55 \mathrm{kPa}$ e $\varphi^{\prime}=23^{\circ}$. A Figura 73 e a Figura 74 
apresentam os módulos de deformabilidade secantes obtidos e o módulos normalizados por p'.
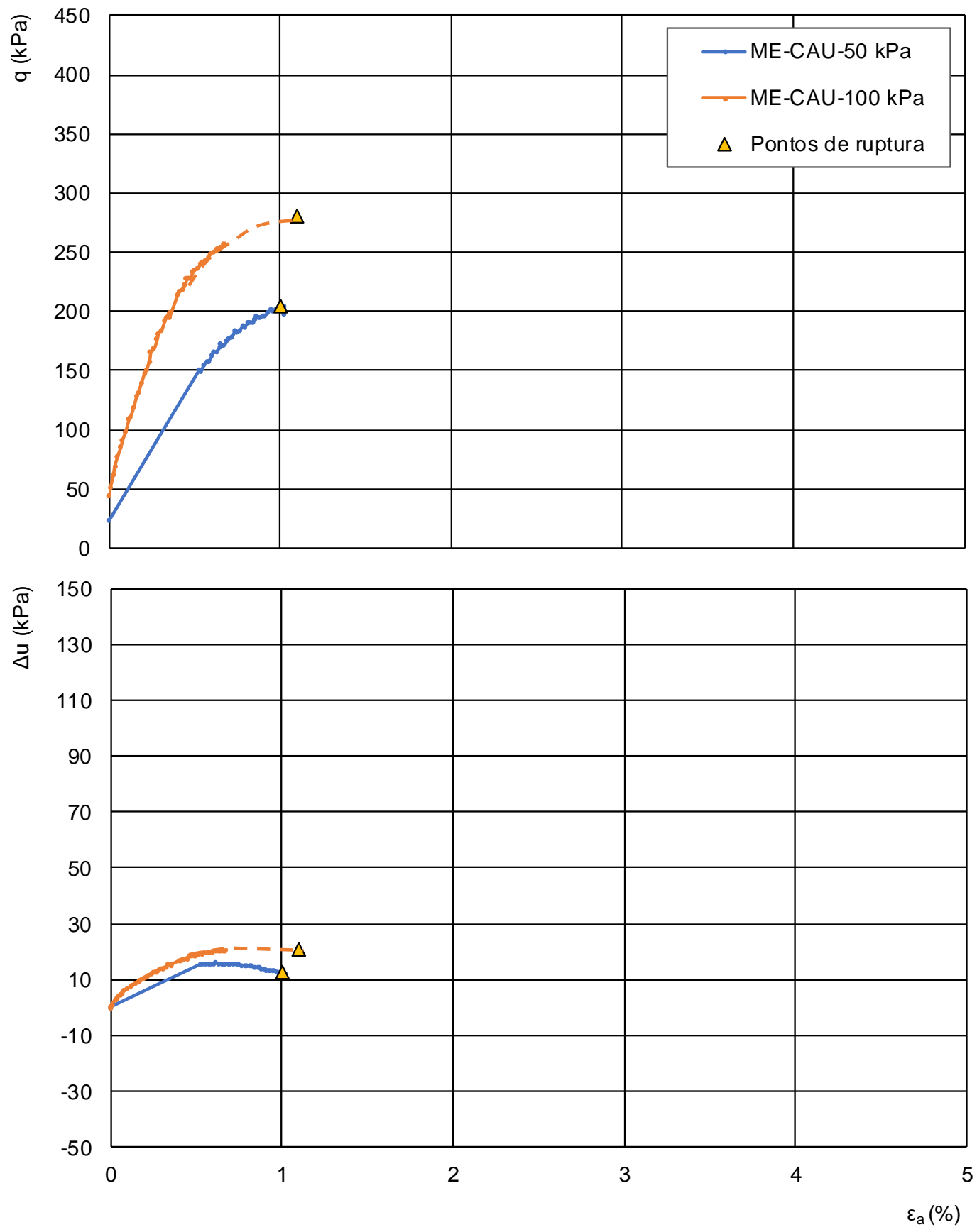

Figura 69. Resultados do ensaio $G$ - gráficos de tensão-deformação e de variação de poropressão versus deformação axial 


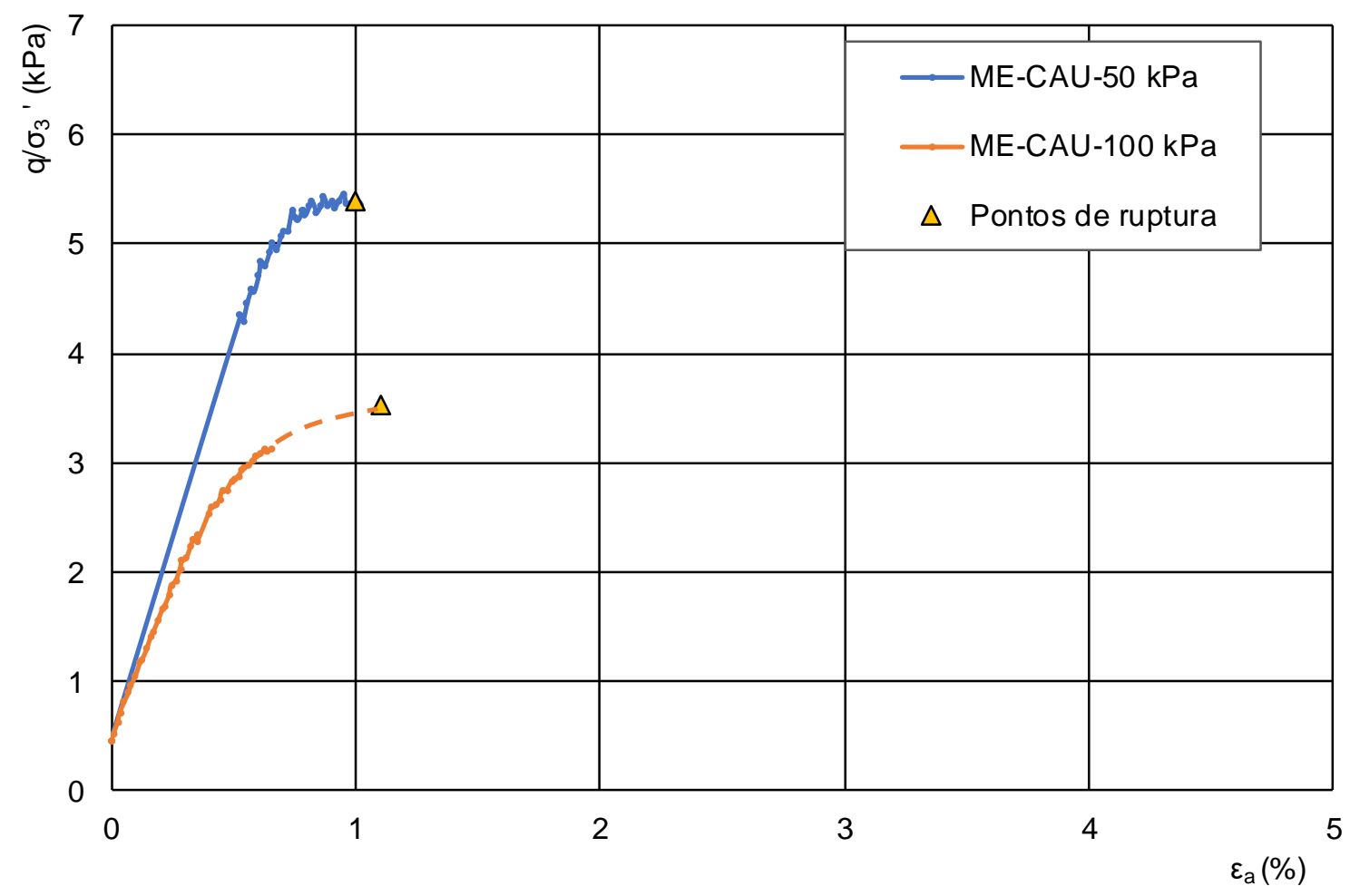

Figura 70. Resultados do ensaio G - gráfico de tensão-deformação normalizado pela tensão confinante efetiva $\left(\sigma_{3}{ }^{\prime}\right)$

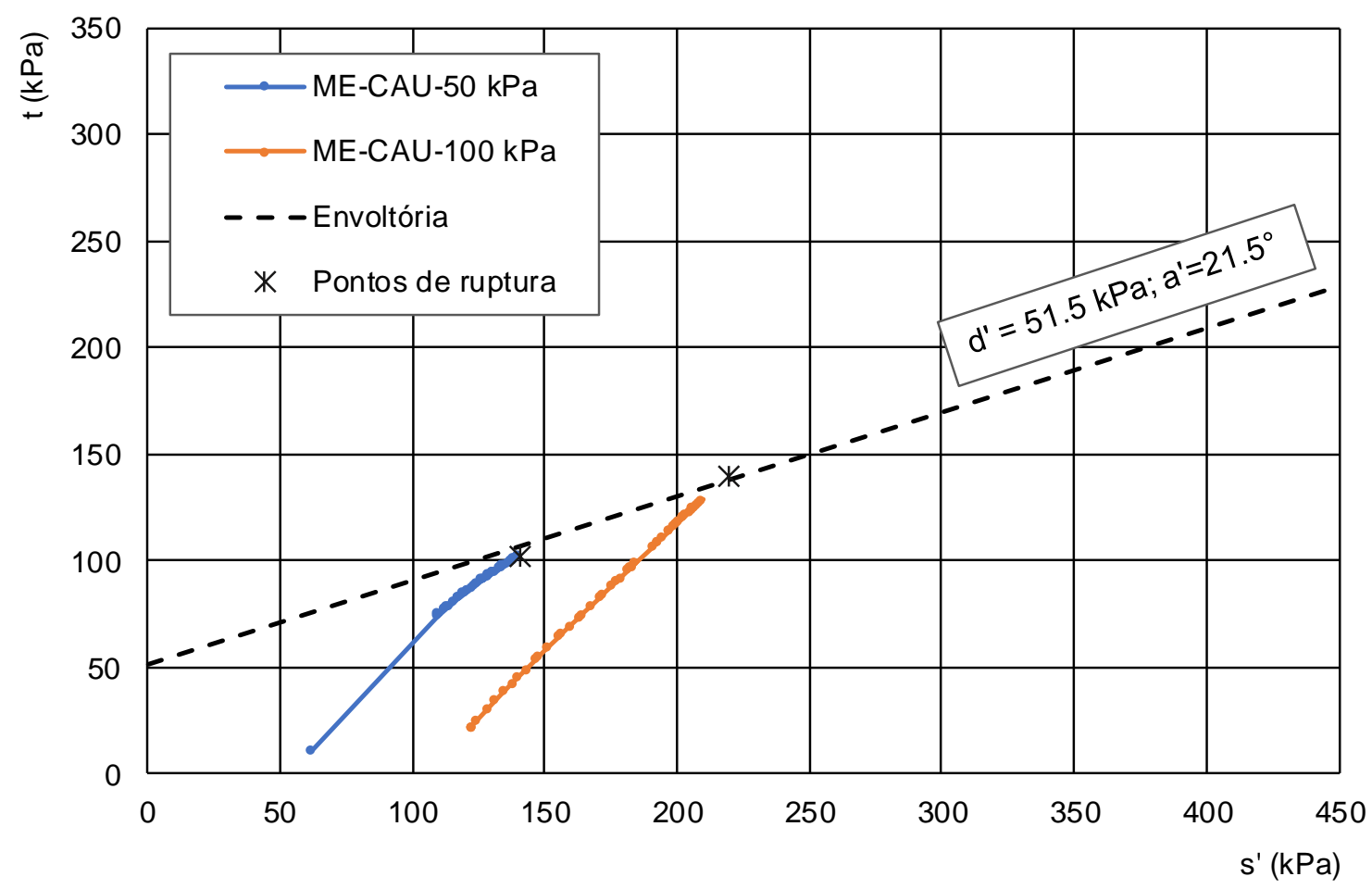

Figura 71. Resultados do ensaio G - trajetórias de tensão 


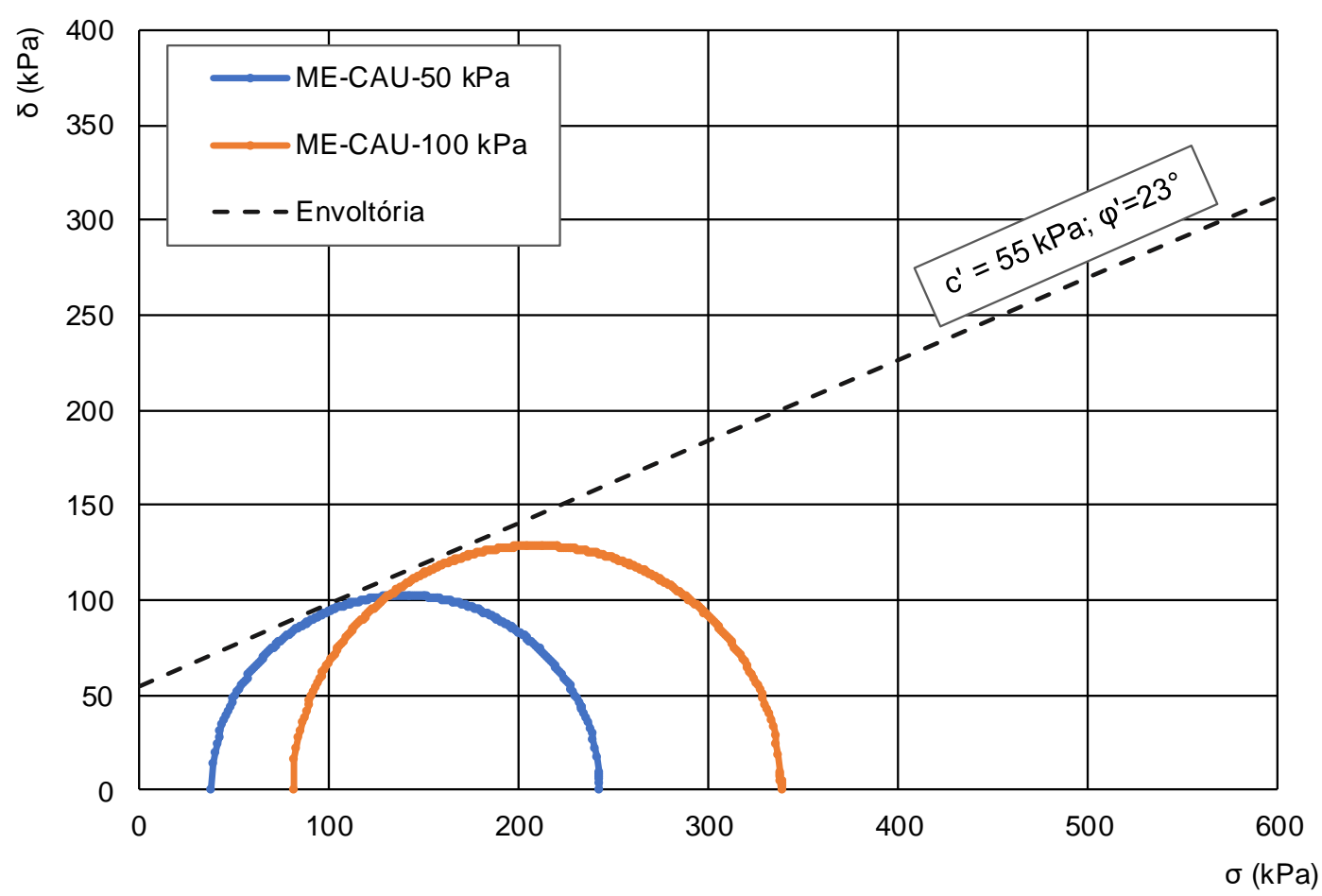

Figura 72. Resultados do ensaio G - círculos de Mohr e envoltória de ruptura

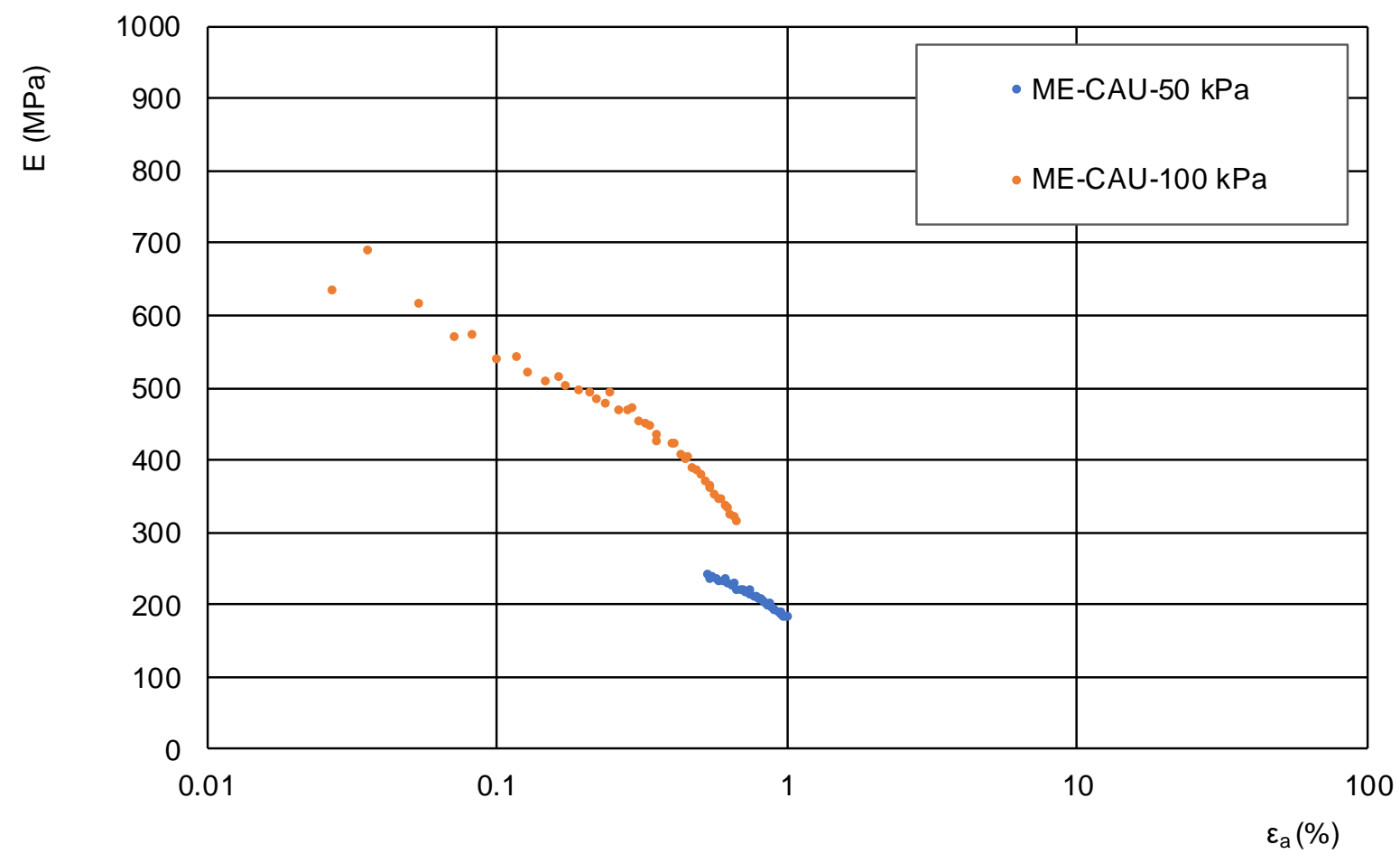

Figura 73. Resultados do ensaio G - módulos de deformação secantes 


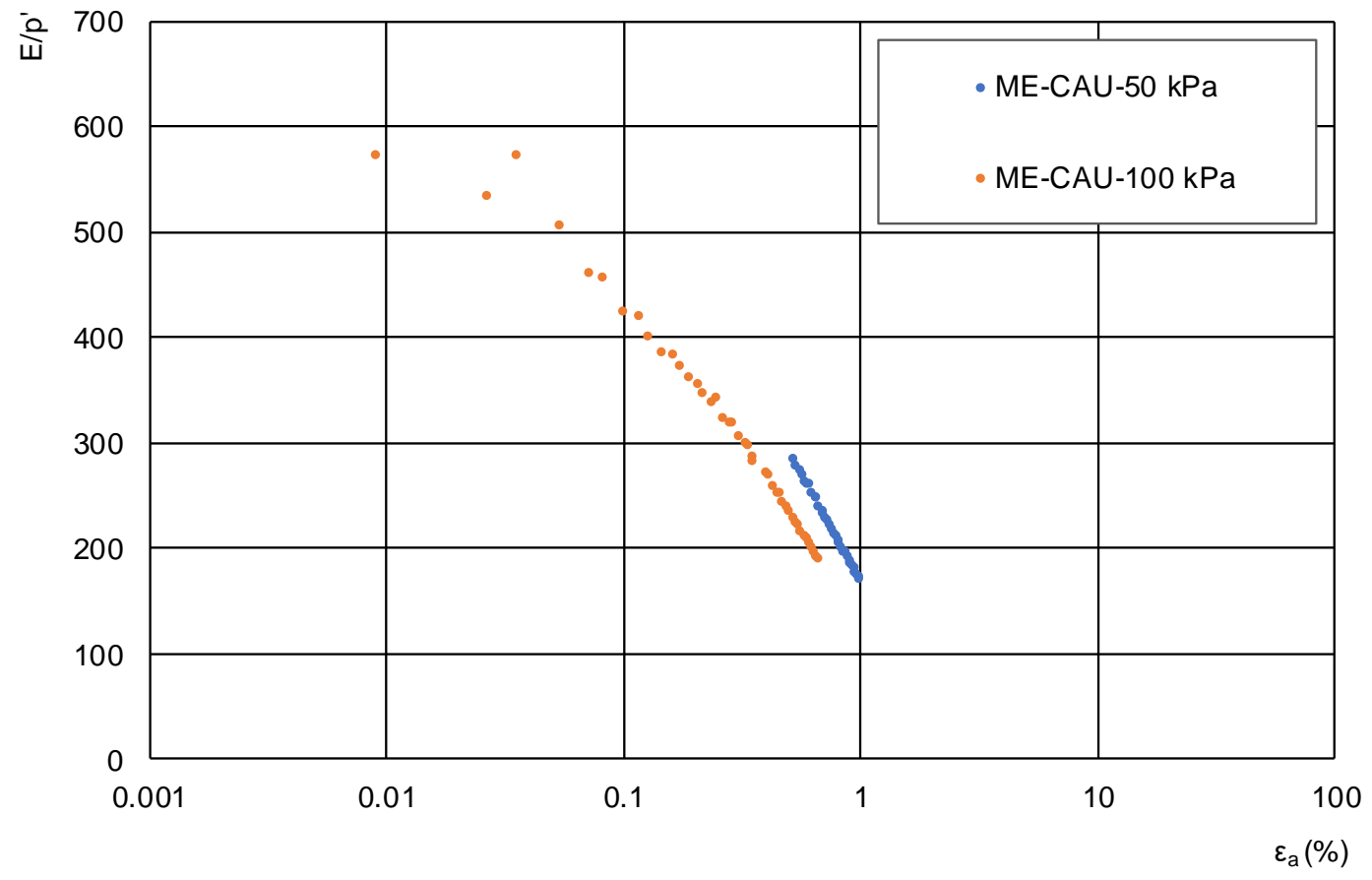

Figura 74. Resultados do ensaio G - módulos de deformação normalizado pela tensão efetiva média ( $p$ ')

\subsubsection{Ensaio H: ME-CIU-50,100,200 kPa}

Foi executado um ensaio multi-estágio do tipo CIU com tensões confinantes de 50, 100 e $200 \mathrm{kPa}$. O corpo de prova foi retirado do bloco indeformado A e suas características iniciais estão apresentadas na

Tabela 12.

Tabela 12. Resultados do ensaio $\mathbf{H}$ - características iniciais do corpo de prova e imagem do corpo de prova cisalhado

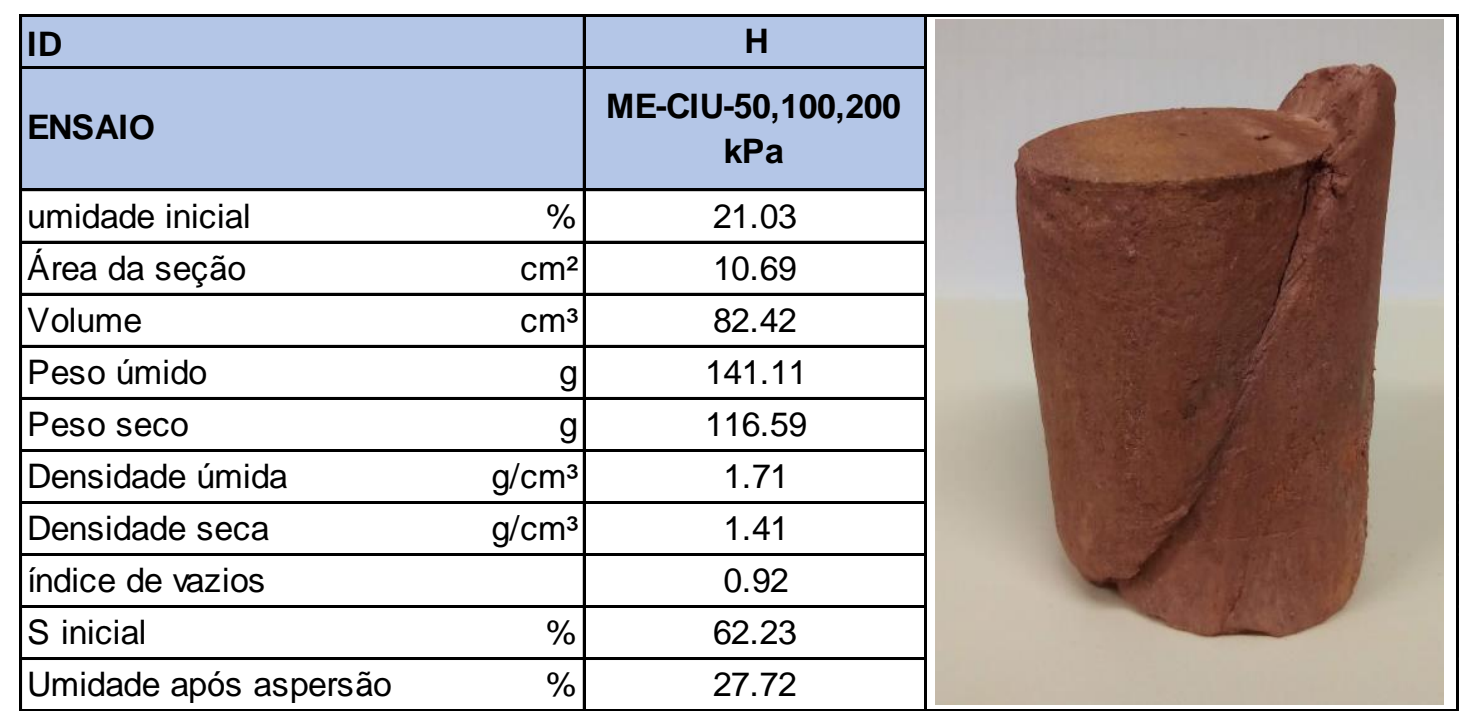


A Figura 75 apresenta os gráficos de tensão-deformação e de variação de poropressão versus deformação axial. Não se observou estabilização da tensão desviatória no último estágio. Em relação ao comportamento das poro-pressões, houve aumento das pressões até o momento da ruptura. A Figura 76 apresenta 0 gráfico tensão-deformação normalizados.
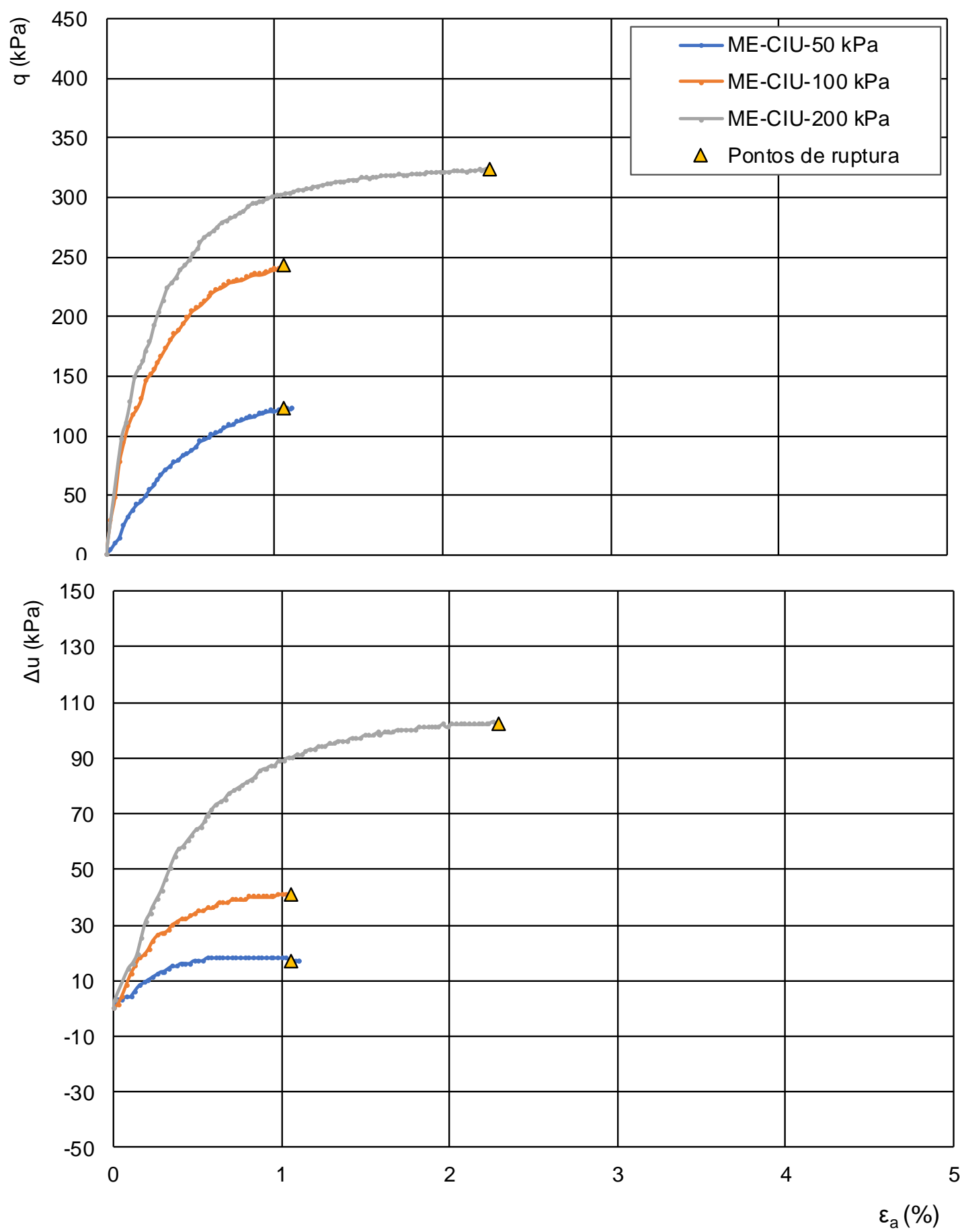

Figura 75. Resultados do ensaio H - gráficos de tensão-deformação e de variação de poropressões versus deformação axial 


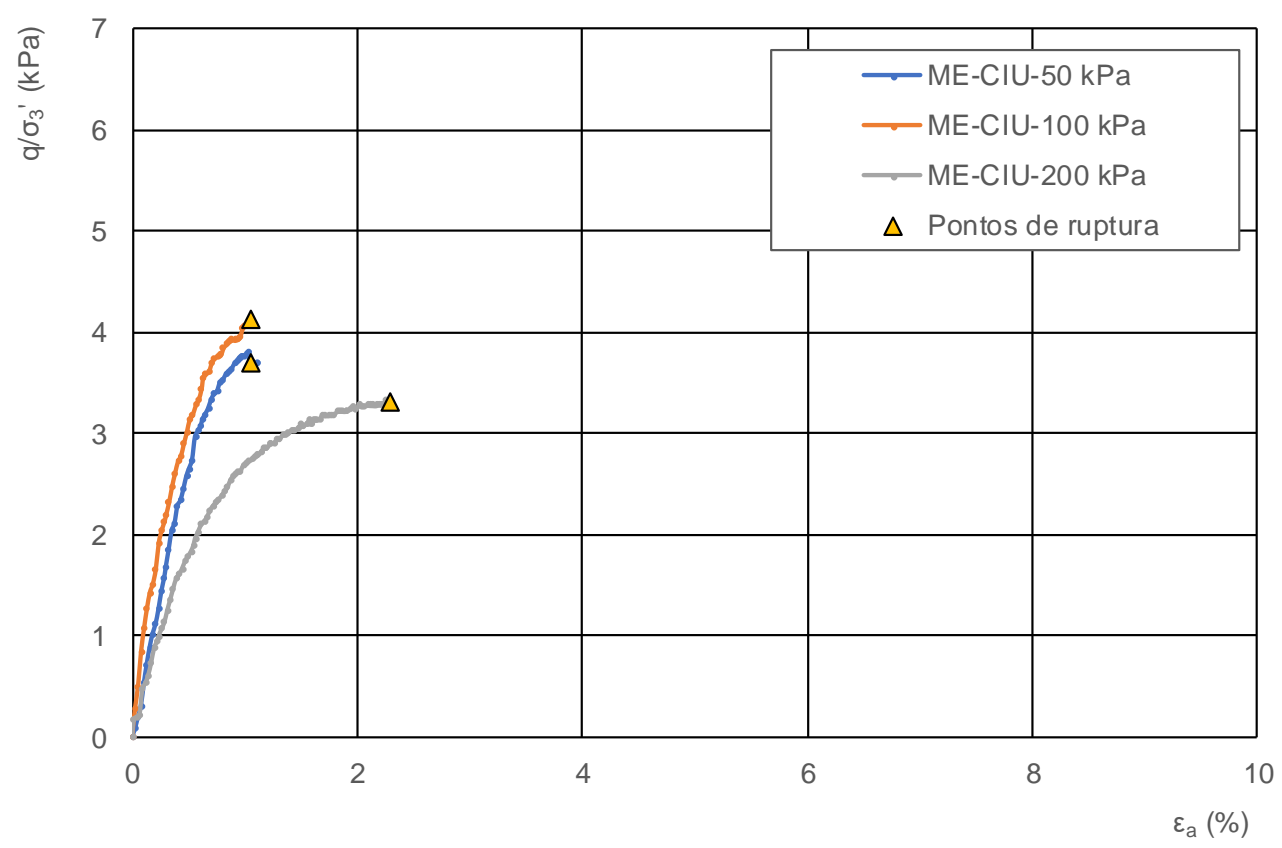

Figura 76. Resultados do ensaio H - gráfico tensão-deformação normalizado pela tensão confinante efetiva $\left(\sigma_{3}{ }^{\prime}\right)$

A Figura 77 e a Figura 78 apresentam as trajetórias de tensão e os círculos de Mohr de ruptura, respectivamente. Os parâmetros de resistência interpretados foram: $c^{\prime}=13$ $\mathrm{kPa}$ e $\varphi^{\prime}=31^{\circ}$.

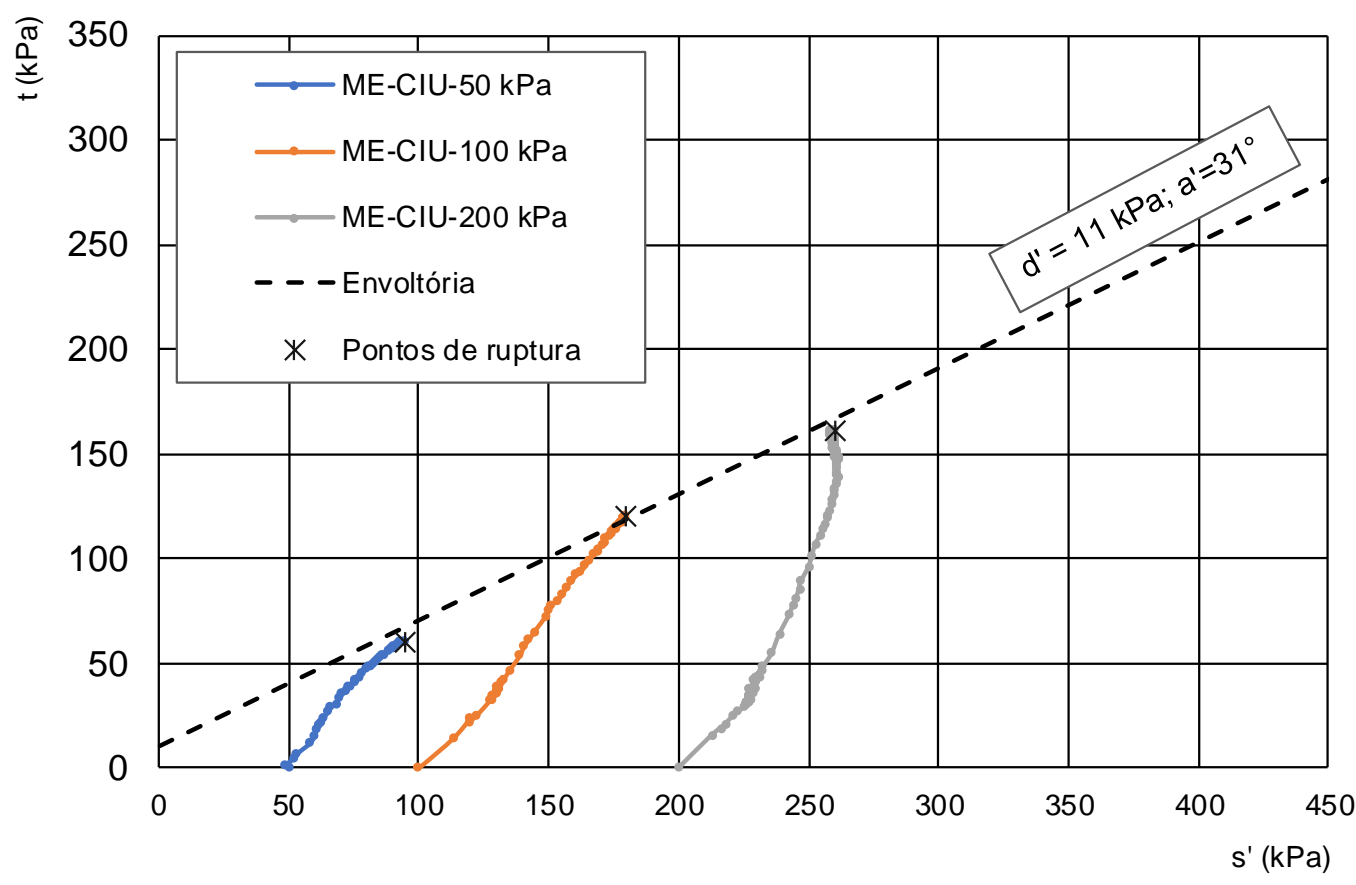

Figura 77. Resultados do ensaio $\mathrm{H}$ - trajetórias de tensão 


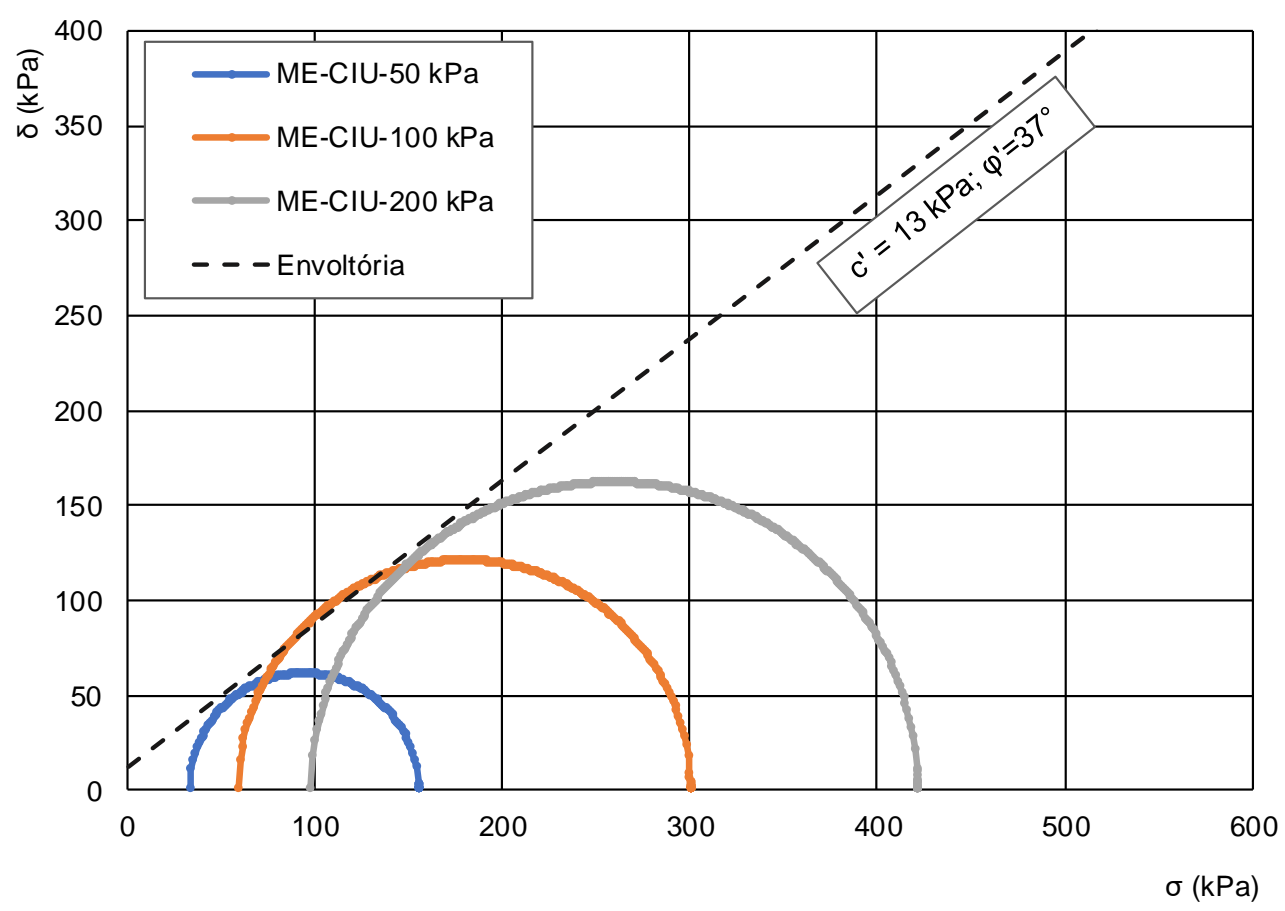

Figura 78. Resultados do ensaio $\mathrm{H}$ - círculos de Mohr e envoltória de ruptura

A Figura 79 apresenta os módulos de deformabilidade secantes obtidos no ensaio. A Figura 80 apresenta os módulos de deformabilidades normalizados por p'.

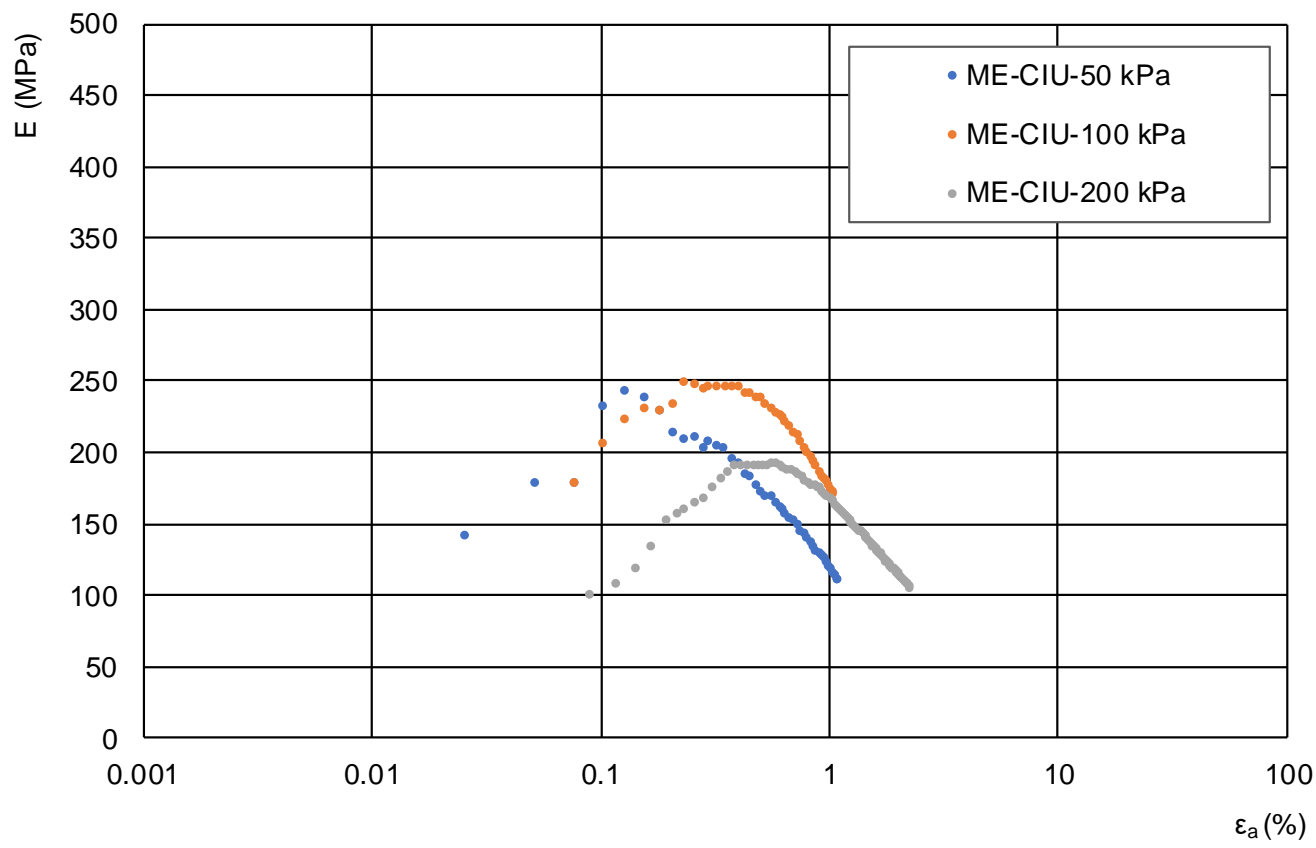

Figura 79. Resultados do ensaio $\mathrm{H}$ - módulos de deformabilidade 


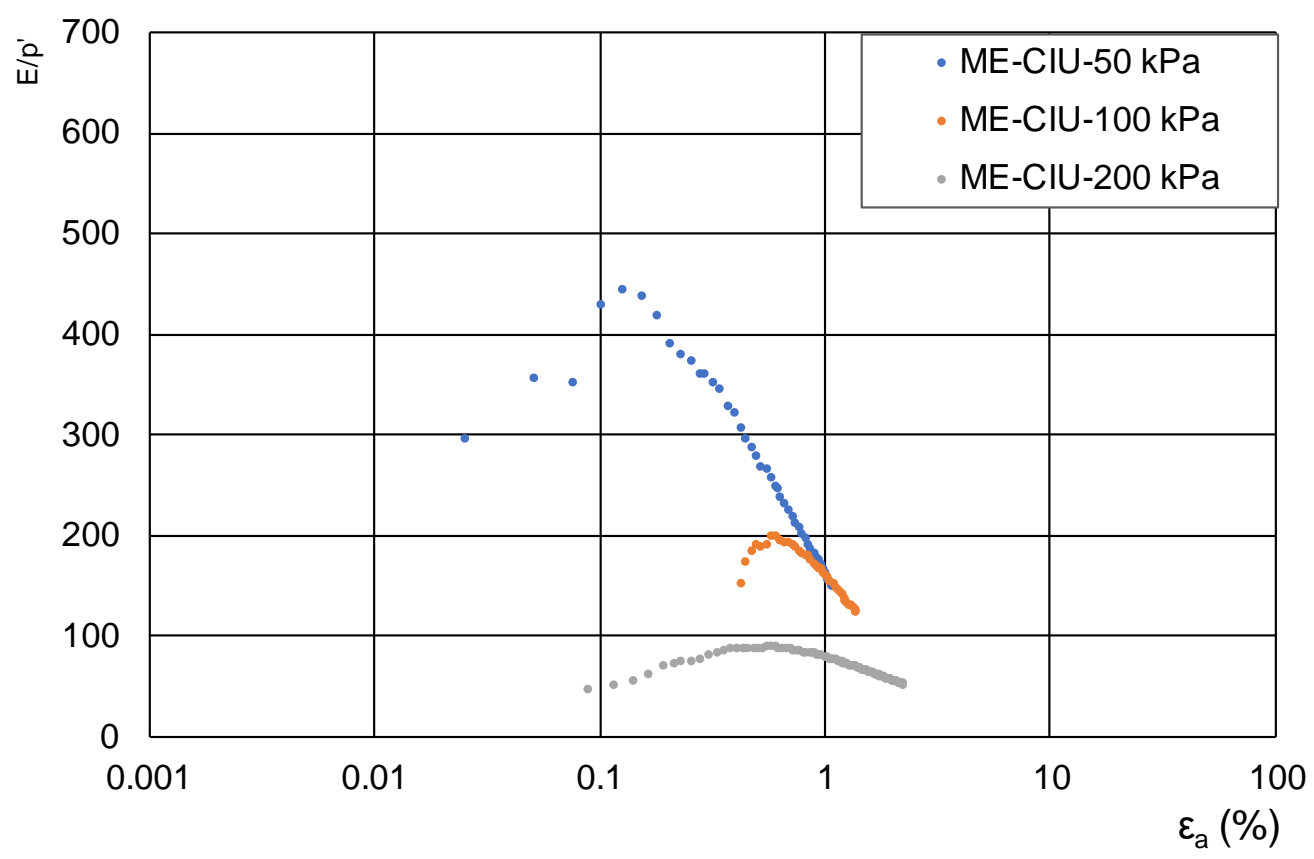

Figura 80. Resultados do ensaio $\mathrm{H}$ - módulos de deformabilidade normalizados pela tensão efetiva média ( $\left.\mathbf{p}^{\prime}\right)$

\subsubsection{Ensaio I: ME-CIU-100,200,300 kPa}

Foi realizado um ensaio multi-estágio do tipo CIU em uma amostra indeformada com tensões de adensamento de 100, 200 e $300 \mathrm{kPa}$. As características iniciais do corpo de prova e a imagem da amostra cisalhada estão apresentadas na Tabela 13. A Figura 81 apresenta os gráficos de tensão-deformação obtidos e de variação de poropressões versus deformação axial.

Tabela 13. Resultados do ensaio I - características iniciais e imagem do corpo de prova cisalhado

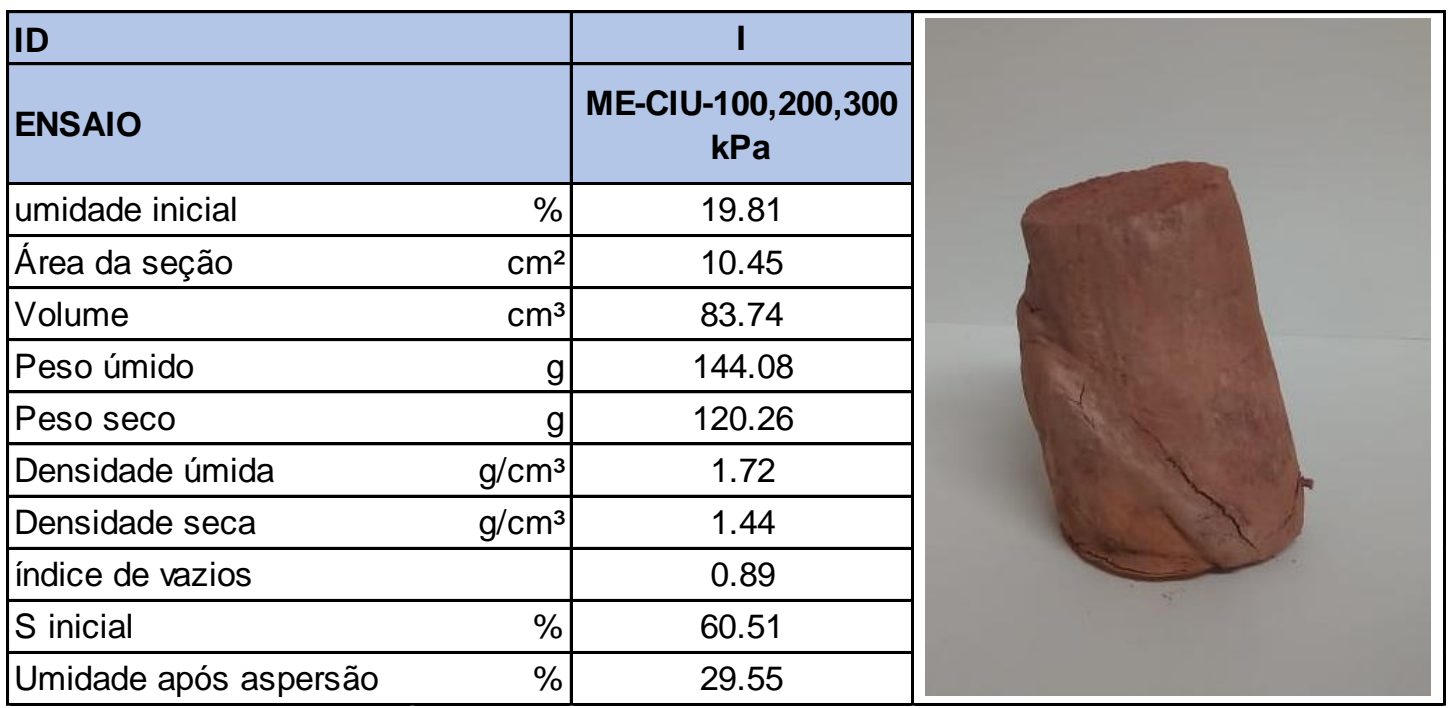



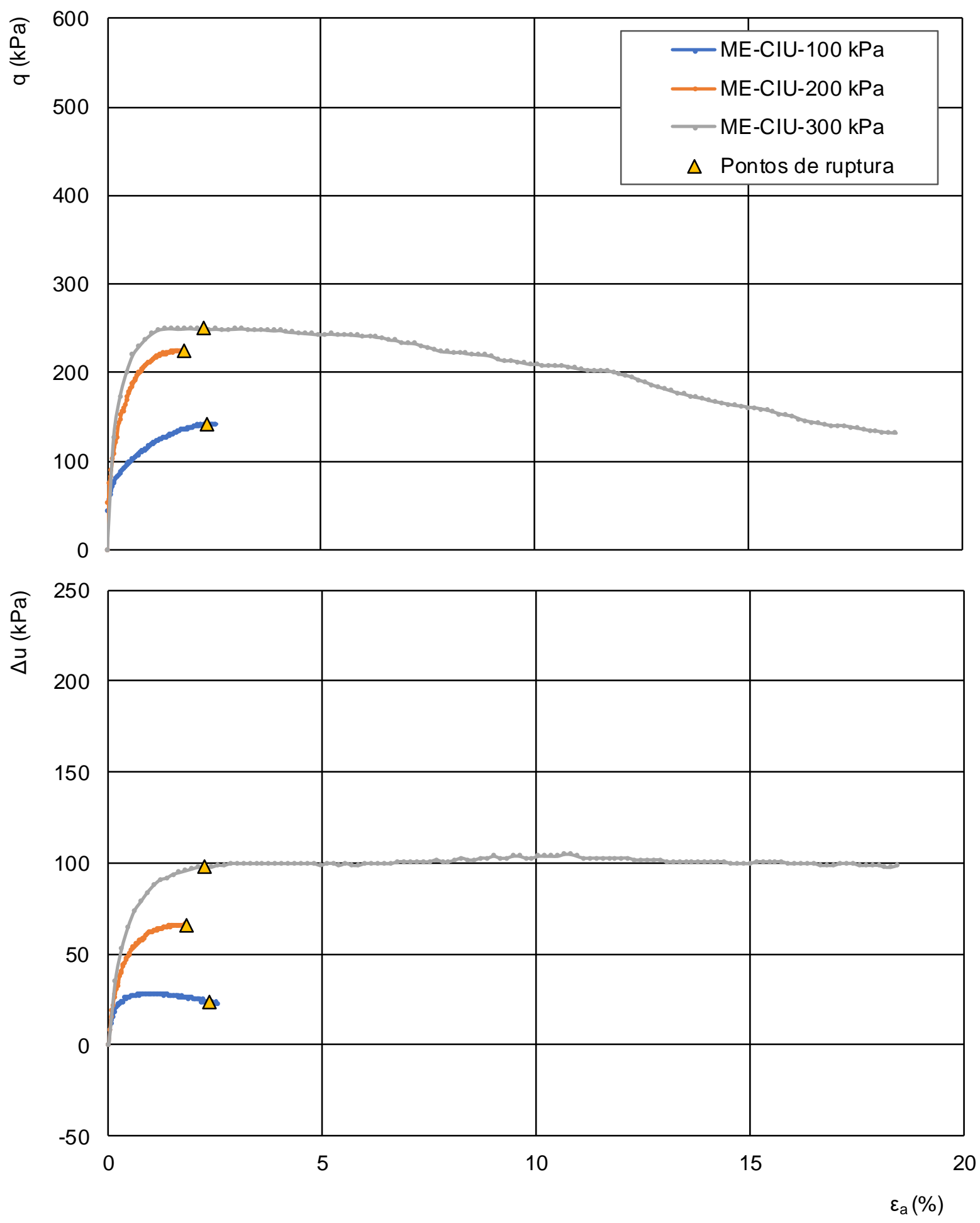

Figura 81. Resultados do ensaio I - curva de tensão-deformação e variação de poro-pressão versus deformação axial

Os ensaios de 100 e $200 \mathrm{kPa}$ foram paralisados no limiar da ruptura, porém é possível observar tendência de formação de pico de resistência no segundo ensaio. No ensaio de $300 \mathrm{kPa}$, a tensão desviadora cai após o pico de tensão, não apresentando 
tendência de estabilização. Uma possibilidade é que este comportamento ocorre devido à perda da estrutura da amostra, onde a resistência do contato entre os grãos é perdida após a ruptura. A quebra de estrutura pode ter ocorrido nos estágios de cisalhamento ou de adensamento anteriores. O mesmo comportamento também pode ser visualizado na Figura 82, que apresenta o gráfico de tensão-deformação normalizado pela tensão confinante efetiva.

Em relação ao comportamento das poro-pressões, verifica-se um pico de poropressões anterior à ruptura, no ensaio de $100 \mathrm{kPa}$. No ensaio de $200 \mathrm{e} 300 \mathrm{kPa}$, ocorre aumento das poro-pressões até a ruptura. No ensaio de $300 \mathrm{kPa}$, após a ruptura, a poro-pressão se estabiliza, próximo a máxima tensão atingida.

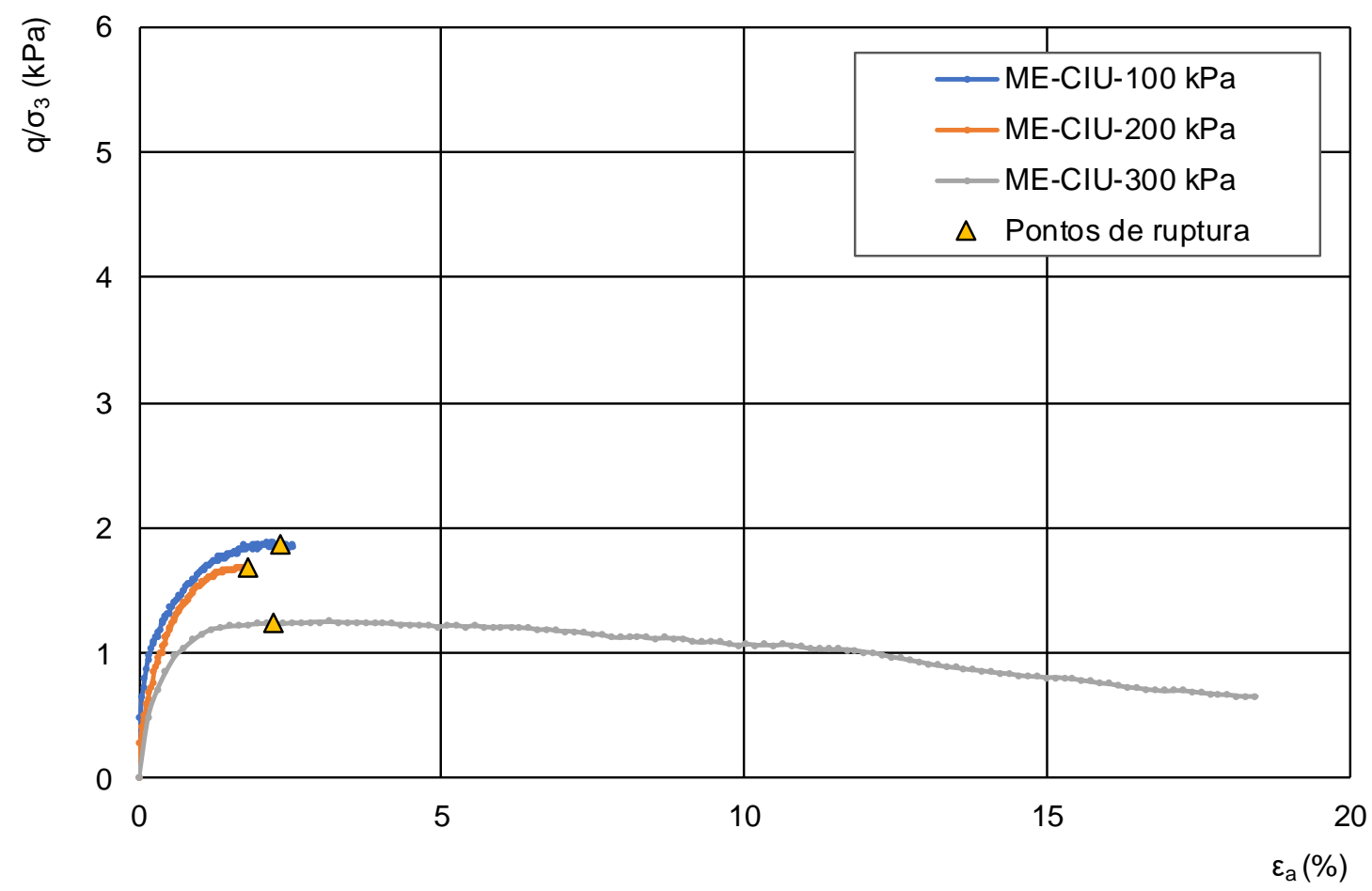

Figura 82. Resultados do ensaio I - curvas de tensão deformação normalizadas pela tensão confinante efetiva

A Figura 83 e a Figura 84 apresentam as trajetórias de tensões e os círculos de Mohr de ruptura, respectivamente. Observa-se que o último estágio de cisalhamento, apresentou resistência um pouco menor que o esperado. Os parâmetros de resistência interpretados foram: $\mathrm{c}^{\prime}=28 \mathrm{kPa}$ e $\varphi^{\prime}=19^{\circ}$. 


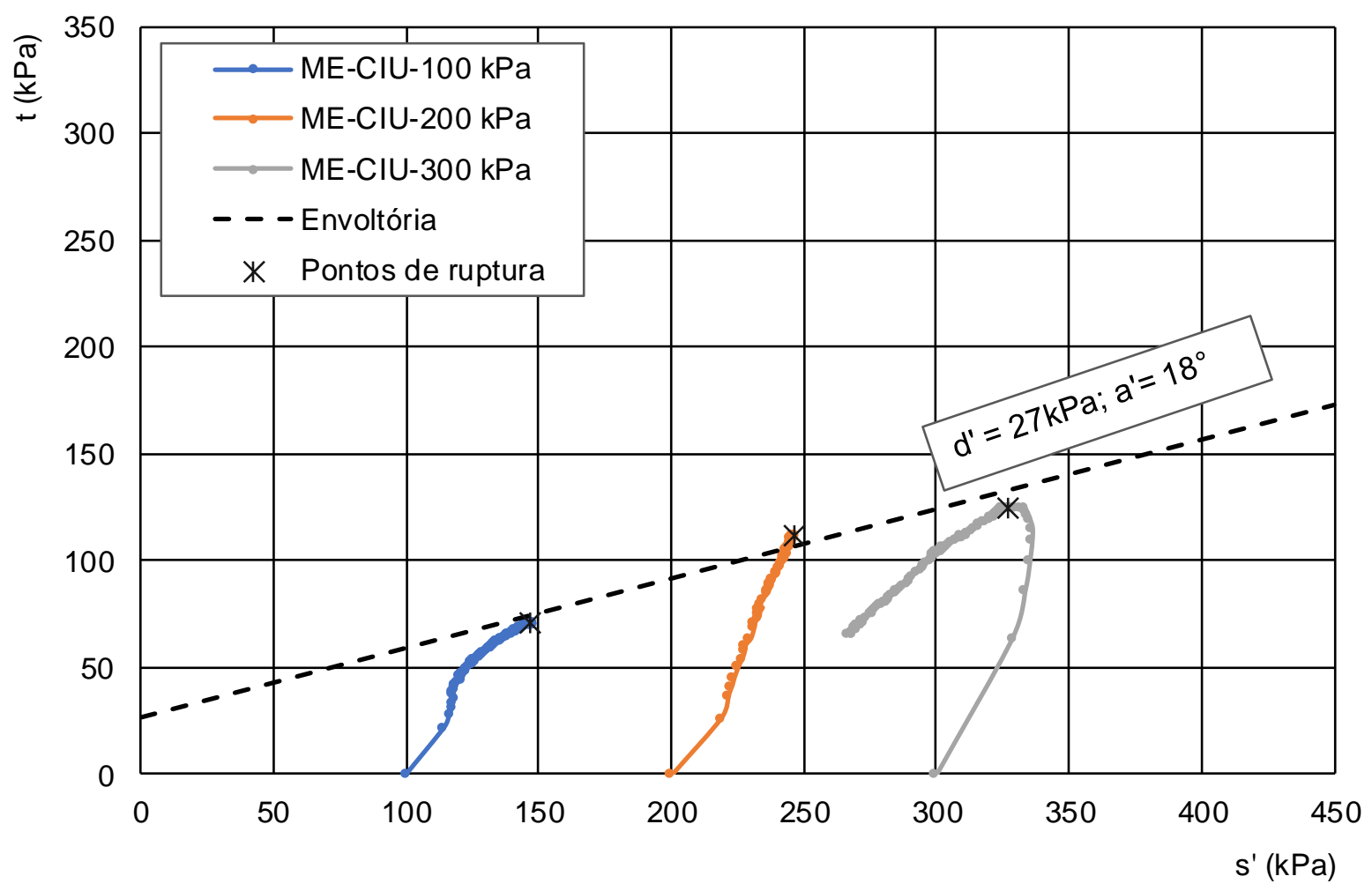

Figura 83. Resultados do ensaio I - trajetórias de tensões

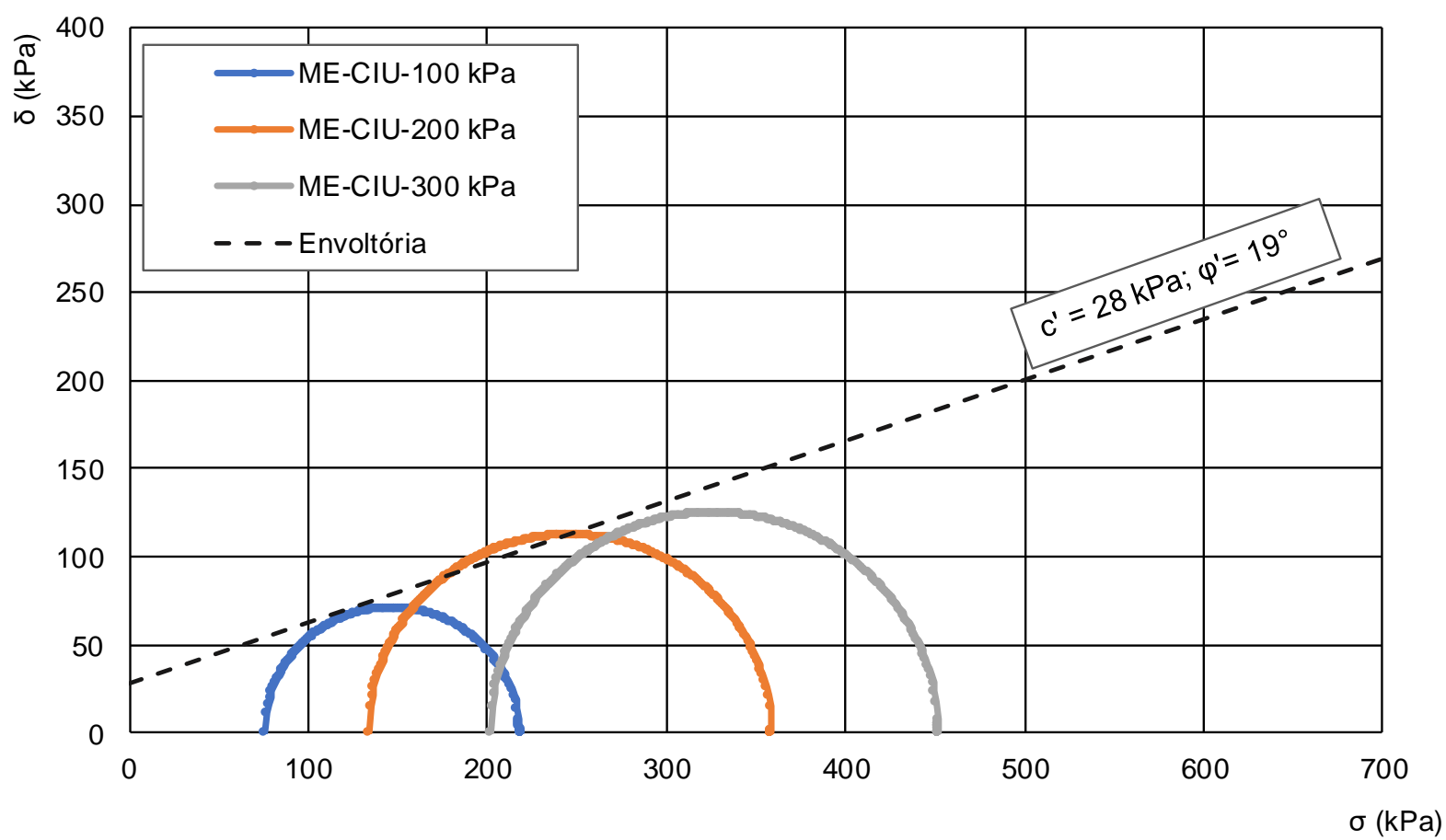

Figura 84. Resultados do ensaio I - círculos de Mohr e envoltória de ruptura 
A Figura 85 e a Figura 86 apresentam os módulos de deformabilidade secantes e os módulos de deformabilidade normalizados por p'. Os módulos obtidos nos ensaios de 200 e $300 \mathrm{kPa}$ obtidos foram semelhantes. Para deformações acima de $2 \%$ as curvas tendem a se sobrepor e os módulos apresentam valores próximos.

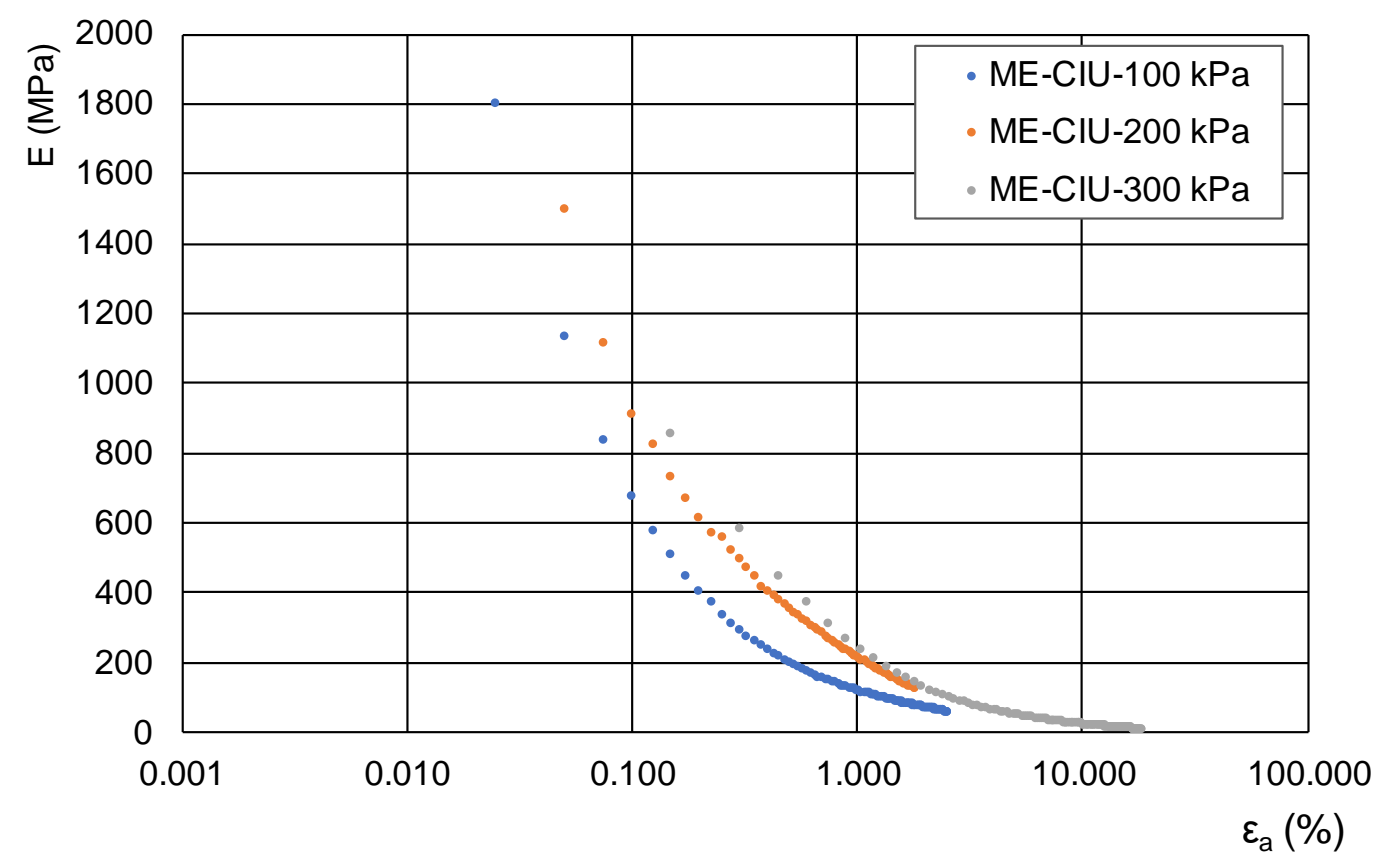

Figura 85. Resultados do ensaio I - módulos de deformabilidade secantes

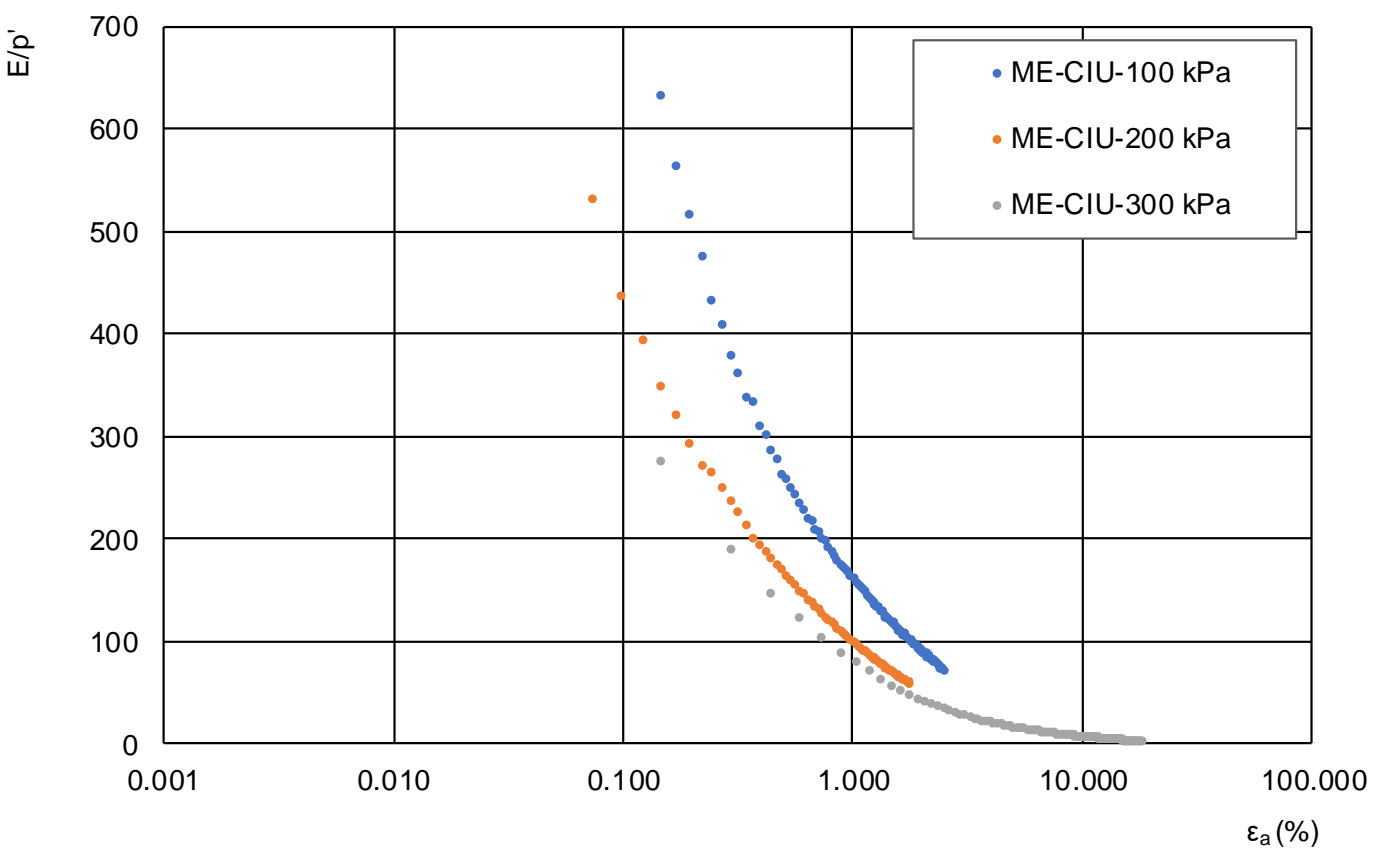

Figura 86. Resultados do ensaio I - módulos de deformabilidade normalizados por p' 


\subsection{Ensaio de Cisalhamento Triaxial do Tipo CIU com Repetição da Tensão de Adensamento (ensaio C: ME-CIU-200,200,200 kPa)}

Com o objetivo de analisar o efeito dos carregamentos e descarregamentos axiais sucessivos ao longo de um ensaio triaxial, efetuou-se um ensaio triaxial multi-estágio do tipo CIU em uma amostra indeformada, com repetição de três carregamentos axiais na tensão confinante de $200 \mathrm{kPa}$ (ensaio $\mathrm{C}$ ). Esperava-se que caso não ocorra grandes perturbações na amostra durante os primeiros estágios de cisalhamento, as tensões desviatórias de ruptura devem ocorrer sempre no mesmo patamar.

As características iniciais do corpo de prova ensaiado e a imagem da amostra após cisalhamento estão apresentadas na Tabela 14.

Tabela 14. Resultados do ensaio C - características iniciais do corpo de prova ensaiado

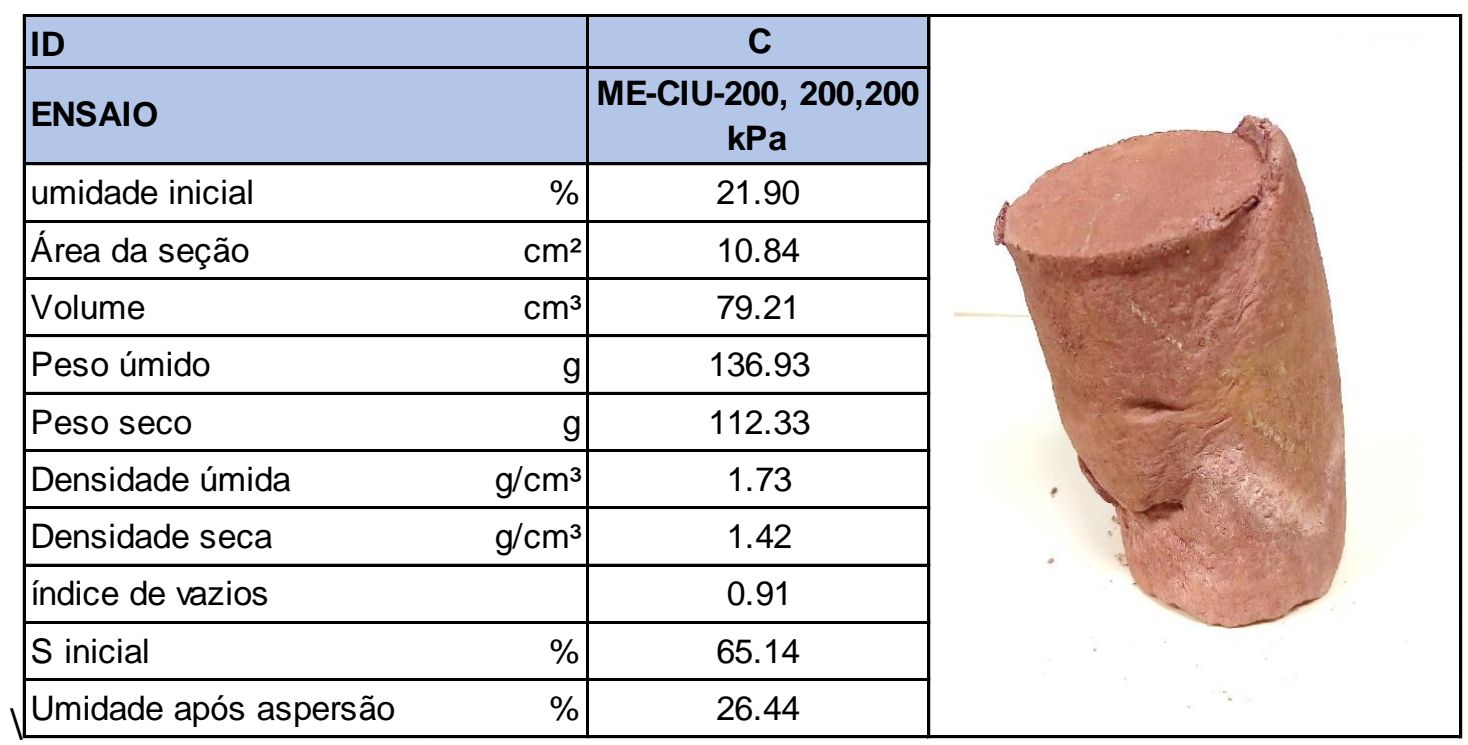

Os gráficos de tensão-deformação e de variação de poro-pressões estão apresentados na Figura 87. No primeiro e segundo estágio, as tensões de ruptura foram estimadas de acordo com o comportamento do solo no último estágio, onde o ensaio é continuado após a ruptura, e pelo conhecimento do comportamento em ensaios prévios. Nos gráficos a seguir, o trecho inferido está indicado pela linha tracejada.

Como pode ser observado, o primeiro estágio de cisalhamento apresentou tensão desviadora de ruptura (203 $\mathrm{kPa}$ ) e variação de poro-pressões ligeiramente mais elevadas que os demais estágios. O segundo estágio de cisalhamento, por sua vez, apresentou a menor tensão de ruptura observada, em $179 \mathrm{kPa}$, porém a variação da poro-pressão apresentou comportamento parecido com o ocorrido no último estágio. 
No terceiro estágio de cisalhamento, a tensão desviadora manteve-se constante após a ruptura. Em relação a variação de poro-pressões, ocorreu aumento da poro-pressão até a ruptura, após este momento, a poro-pressão é estabilizada.
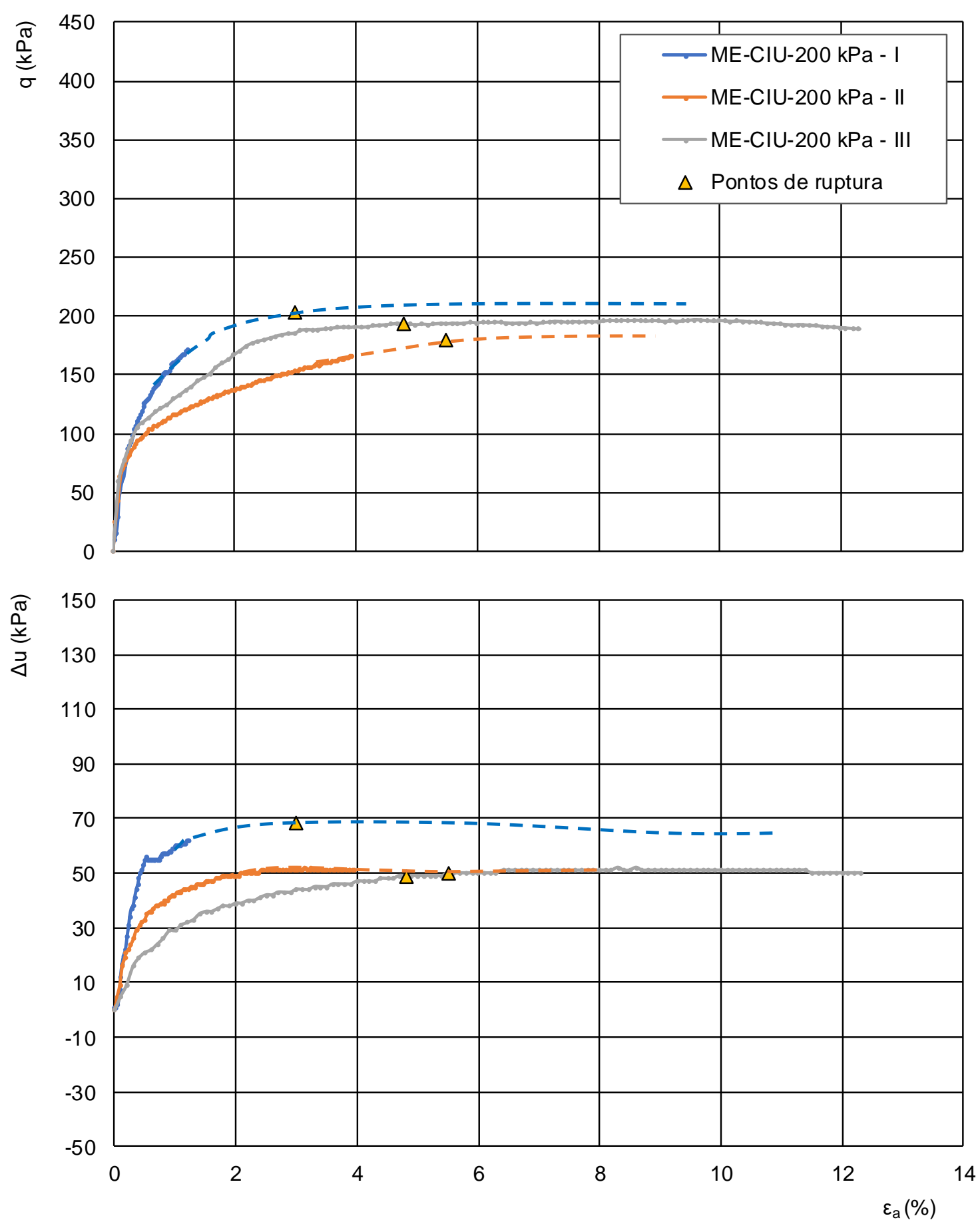

Figura 87. Resultados do ensaio C - curvas de tensão-deformação e variação de poropressões versus deformação axial

$\mathrm{Na}$ trajetória de tensões efetiva (Figura 88), observa-se um comportamento parecido nos três estágios, com ponto de ruptura próximos. Observa-se também que ocorre 
maior geração de poro-pressões nos estágios iniciais do ensaio, com diminuição gradativa ao longo do ensaio multi-estágio. Na trajetória de tensões totais (Figura 89), as curvas se sobrepõem.

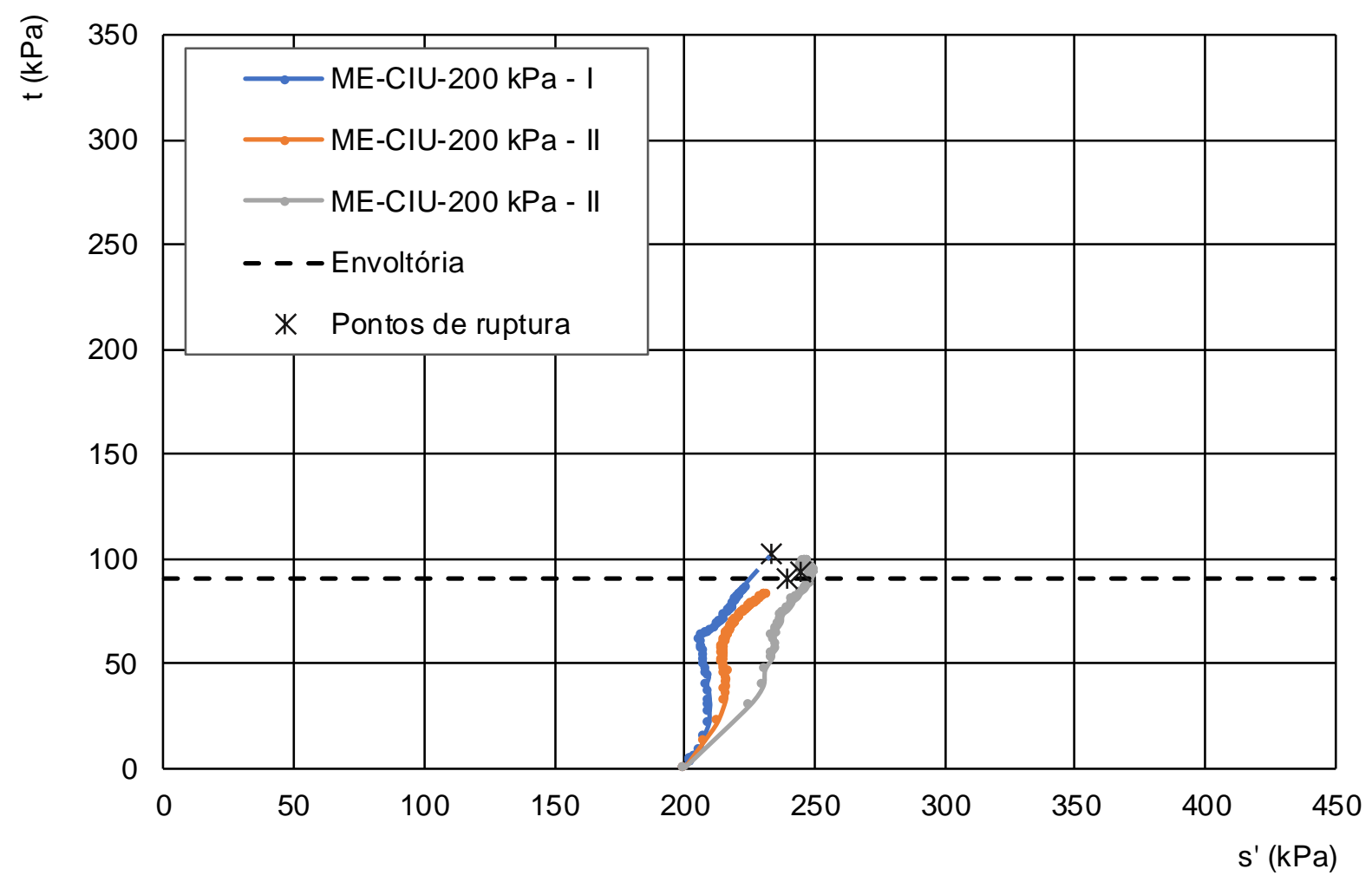

Figura 88. Resultados do ensaio C - trajetória de tensões efetivas

Na Figura 90 estão apresentados os círculos de Mohr obtidos, plotados até o ponto terminal do ensaio. No último estágio de cisalhamento, ocorre maior mobilização das tensões, devido a continuação do ensaio após a ruptura. É provável que as diferenças no diagrama de Mohr fossem minimizados caso fossem plotadas as tensões de ruptura inferidas. Ainda assim, os três estágios apresentaram círculos de Mohr correlacionáveis. 


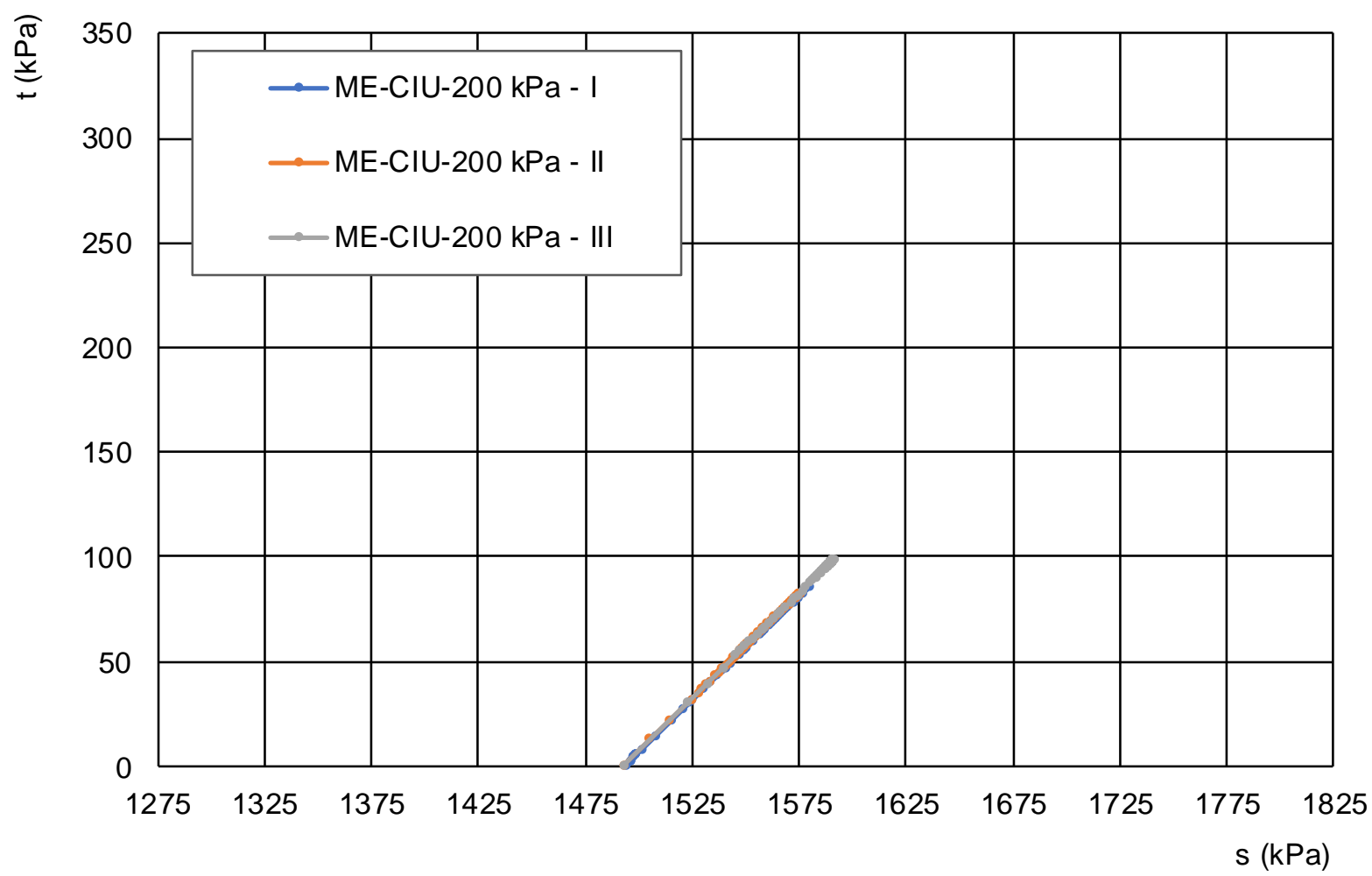

Figura 89. Resultados do ensaio C - Trajetória de tensões totais

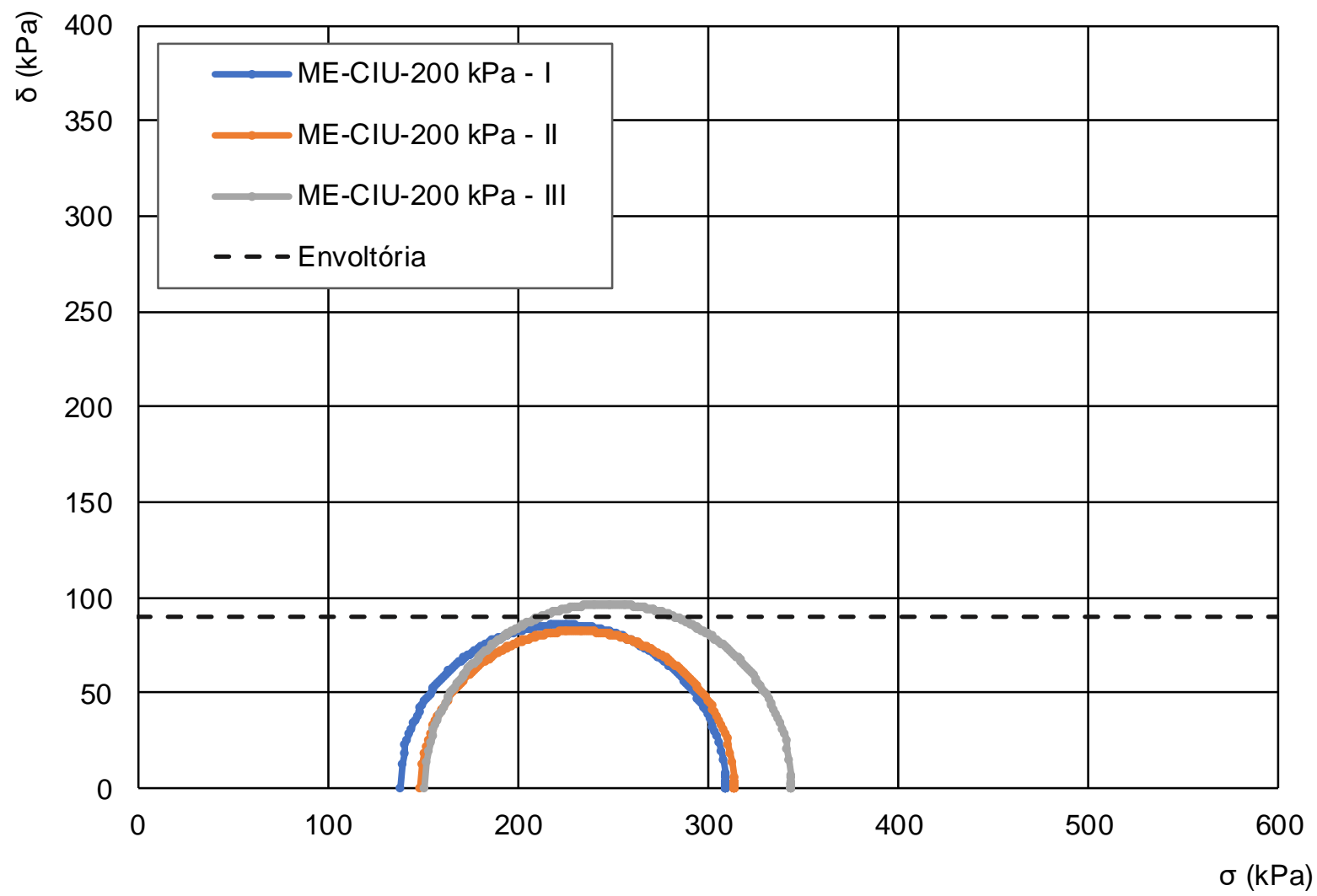

Figura 90. Resultados do ensaio C - círculo de Mohr obtidos 
A Figura 91 e a Figura 92 trazem os módulos de deformação secantes e os módulos de deformação normalizado por p', respectivamente. Foram obtidos valores de $\mathrm{E}$ (módulo de Young), após $0.05 \%$ de deformação.

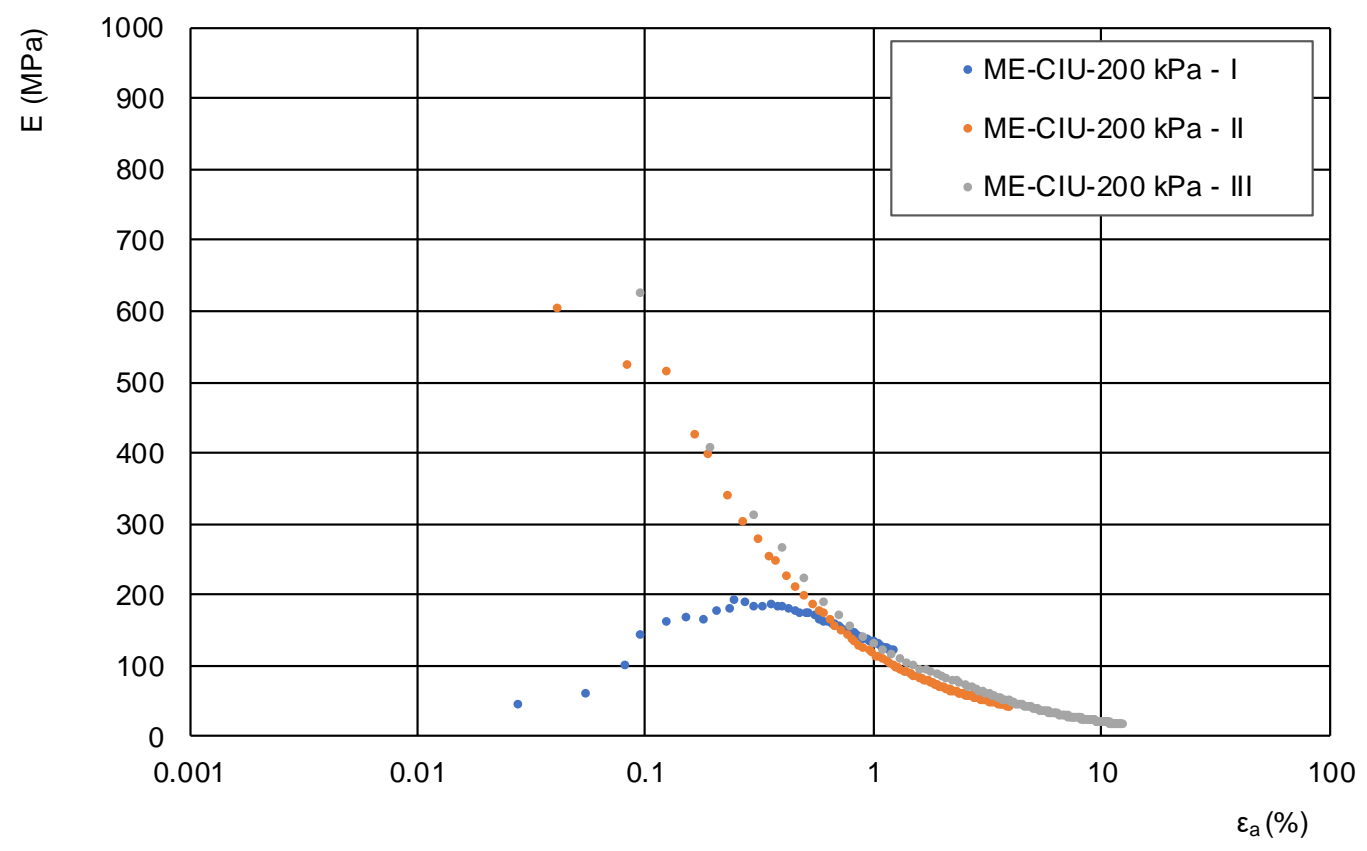

Figura 91. Resultado s do ensaio $\mathrm{C}$ - módulos de deformação

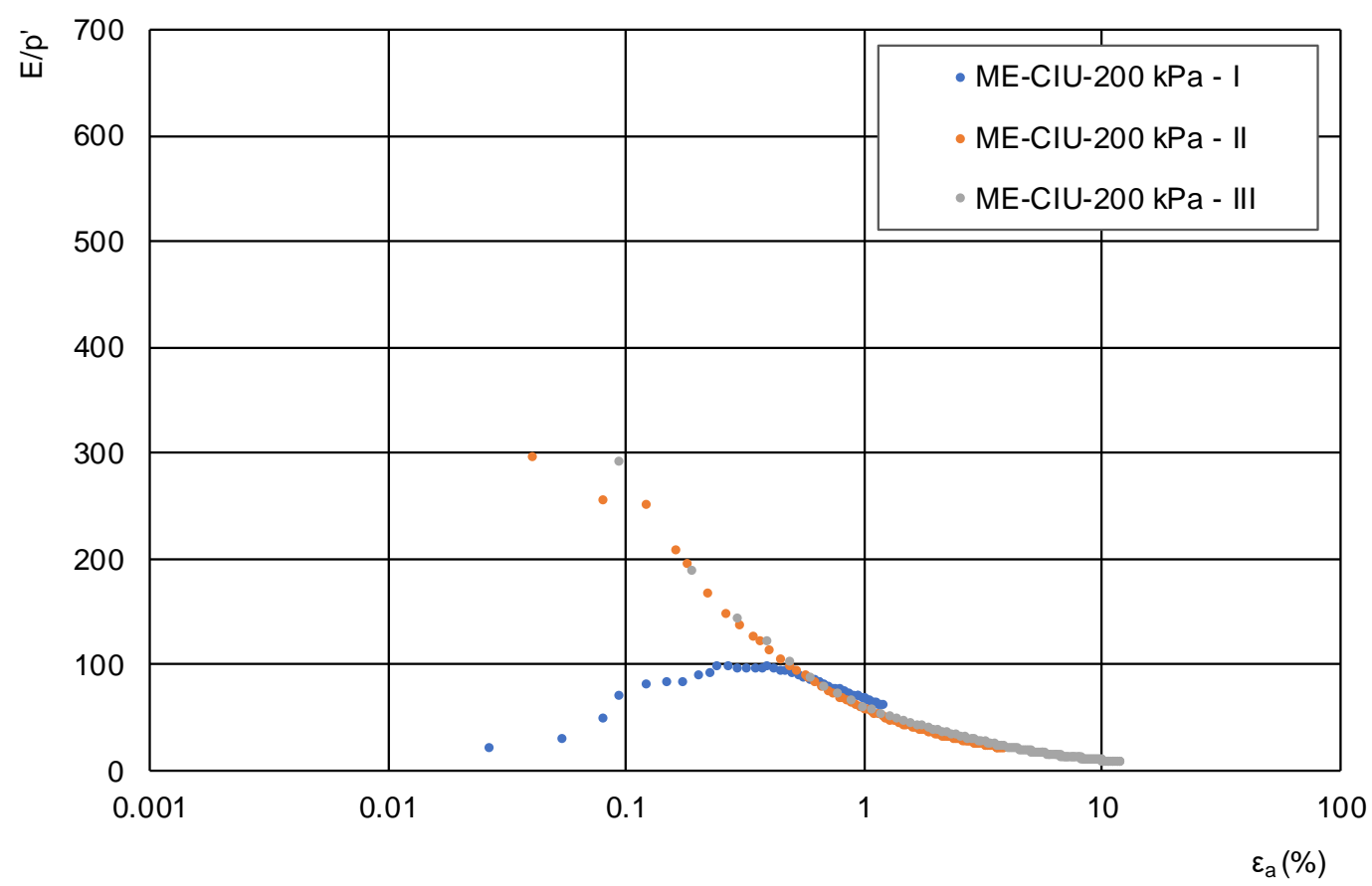

Figura 92. Resultados do ensaio C - módulos de deformação normalizado pela tensão efetiva média ( $p$ ')

Como se trata de um ensaio isotrópico, no início do ensaio, onde ainda são considerados movimentações externas ao corpo de prova, os módulos de deformação 
são afetados e, por isso, aconselha-se os módulos obtidos até $0.5 \%$ de deformação no primeiro estágio não sejam considerados.

Desconsiderando a deformação inicial do primeiro estágio, os valores dos módulos de deformação apresentam o mesmo comportamento ao longo dos três estágios. Tal fato também é evidenciado na figura 53, onde as curvas se sobrepõem. 


\section{DISCUSSÃO}

Este capítulo apresenta a avaliação do método multi-estágio em amostras compactadas e indeformadas, a partir da análise e discussão dos resultados apresentados no capítulo 5. Também será discutido o efeito da heterogeneidade do solo em estudo na obtenção dos parâmetros de resistência em ensaios triaxiais convencionais. Adicionalmente, as análises obtidas em MEV serão apresentadas e, a partir destas imagens, serão abordados tópicos da evolução microestrutural ao longo de ensaios triaxiais e o efeito dos carregamentos axiais dos estágios intermediários de cisalhamento em ensaios multi-estágio.

\subsection{Avaliação de Ensaios Multi-Estágios em Amostras Compactadas}

O comportamento das amostras compactadas ao longo dos ensaios A e B foram comparados e as diferenças ocorridas ao longo dos ensaios serão discutidas neste item.

As características iniciais dos corpos de prova ensaiados estão apresentadas na Tabela 7. Os corpos de prova foram moldados utilizando os mesmos parâmetros de umidade e densidade seca e, por isso, podem ser considerados homogêneos. Dessa forma, as diferenças comportamentais ocorridas entre os dois tipos de ensaios se devem, majoritariamente, ao processo mecânico do ensaio e não às características dos corpos de prova.

A comparação entre o ensaio multi-estágio e o convencional foi realizada a partir das seguintes observações:

- Comportamento tensão-deformação e variação de poro-pressões;

- Trajetórias de tensões efetivas;

- Parâmetros de resistência efetivos obtidos; e

- Parâmetros de deformabilidade.

Embora todos os aspectos aqui apontados se relacionem entre si, as observações serão apresentadas separadamente.

\subsubsection{Comportamento tensão-deformação e desenvolvimento de poro-pressões}

As curvas de tensão-deformação obtidas nos ensaios A e B estão apresentadas na Figura 93. Como pode ser observado, nos dois primeiros estágios, realizados com tensões confinantes de $100 \mathrm{kPa}$ e $200 \mathrm{kPa}$, as curvas de tensão-deformação obtidas 
apresentaram comportamento bem parecidos. Porém, as tensões de ruptura estimados no ensaio multi-estágio foram ligeiramente menores do que aqueles obtidos nos ensaios convencionais. Possivelmente tais diferenças poderiam ser minimizadas caso as etapas de cisalhamento do ensaio multi-estágio fossem continuadas até maiores deformações.
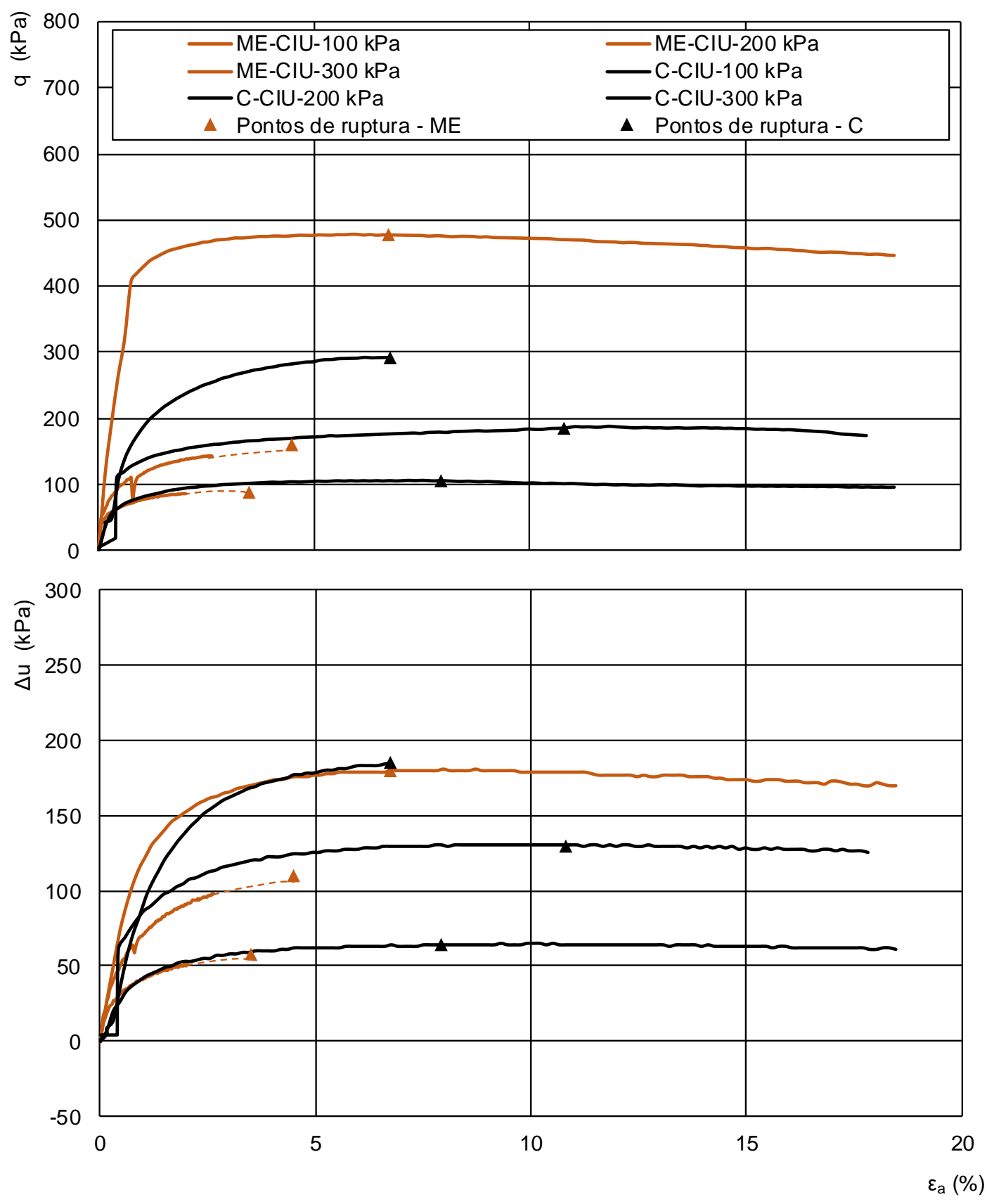

Figura 93. Comparação entre o comportamento de tensão-deformação e de variação de poropressões resultantes dos ensaios A e B. 
A Figura 86 também apresenta a variação de poro-pressões ao longo dos ensaios. Também observou-se menor geração de poro-pressões nos dois primeiros estágios do ensaio multi-estágio. As diferenças observadas nos dois primeiros estágios são baixas e se enquadram na margem de erro intrínseca ao ensaio, a diferença máxima entre as tensões desviadoras de ruptura é de 16\%. A diferença da poro-pressão no momento da ruptura foi de $11 \%$ para o ensaio de $100 \mathrm{kPa}$ e $15 \%$ para o ensaio de $200 \mathrm{kPa}$.

Porém, esta semelhança de comportamento não é repetida no último estágio do teste. No ensaio multi-estágio realizado com tensão confinante de $300 \mathrm{kPa}$ foram atingidas tensões desviadoras muito elevadas, quando comparado com as observadas no ensaio convencional. A diferença da tensão desviadora de ruptura entre os dois ensaios foi de $184 \mathrm{kPa}$, representando um aumento de $62 \%$.

No ensaio multi-estágio de $300 \mathrm{kPa}$, observa-se um aumento da tensão até $0.95 \%$ de deformação. Desta forma, interpreta-se que a amostra ensaiada com a técnica multiestágio tornou-se mais rígida e resistente no último estágio do teste.

Já a variação de poro-pressões no último estágio dos testes apresentou comportamento semelhante nos ensaios A e B. A diferença entre a poro-pressão no momento da ruptura é de apenas $5 \mathrm{kPa}$, o que representa uma variação de $2 \%$ entre os testes.

Os autores Parry e Nadajarah (1973) obtiveram resultados parecidos com os apresentados neste item, com ocorrência de ganho de rigidez e resistência ao longo de ensaios multi-estágios. Como discutido no item 2.3.2, os autores realizaram ensaios convencionais e multi-estágios em argilas indeformadas e remoldadas e observaram um aumento expressivo das tensões desviadoras de ruptura nos últimos estágios do teste. Os autores atribuem este comportamento às perturbações causadas na amostra nos estágios iniciais de cisalhamento, porém, não explicam as mudanças estruturais ocorridas na amostra ao longo dos estágios.

Uma possível hipótese que explica este aumento de resistência no último estágio é a ocorrência de densificação da amostra nos estágios de cisalhamento anteriores. Esta densificação resulta na diminuição do índice de vazios do solo, aumentando a zona de contato entre os grãos e, por isso, a resistência gerada pelo atrito nestes contatos entre os grãos aumenta e é mobilizada no último estágio do teste. 
Durante os estágios de cisalhamento, onde ocorre compressão axial da amostra, ocorre aumento da poro-pressão. No fim dos estágios, quando as drenagens são abertas para a próxima etapa de adensamento, a água comprimida é expelida, diminuindo o volume original da amostra e mantendo-a densificada.

\subsubsection{Trajetórias de tensão}

A Figura 94 apresenta as trajetórias de tensões obtidas nos ensaios A e B. Observase que os dois primeiros estágios dos ensaios apresentam trajetórias de tensões coincidentes. As diferenças de tensões e variações de poro-pressões ocorridas nesses dois estágios se anulam no cálculo das tensões efetivas, resultando na coincidência das trajetórias de tensões. Nos dois primeiros estágios, as tensões de ruptura não são totalmente mobilizadas no ensaio multi-estágio. Porém, este fato não afeta na interpretação da envoltória de ruptura.

No último estágio, a trajetória de tensões do ensaio multi-estágio é deslocada para a direita devido ao aumento abrupto de tensão desviadora até $0,95 \%$ de deformação. Porém, os pontos de ruptura do último estágio do ensaio $B$ ocorre próximo à envoltória interpretada para o ensaio $A$.

Parry e Nadajarah (1973) e Nambiar et al (1985) obtiveram resultados parecidos e interpretaram que apesar das tensões de ruptura serem consideravelmente maiores nos ensaios multi-estágios, a ruptura ocorre na mesma trajetória de tensões obtida em ensaios convencionais, como ilustrado na Figura 13.

Nestes casos, a densificação da amostra ocorrida nos estágios anteriores não modifica os parâmetros de resistência do solo. A diminuição do volume da amostra também ocorreria caso a amostra fosse adensada à níveis maiores de tensão confinante e, como discutido anteriormente, esta densificação aumenta a resistência ao atrito entre os grãos devido a diminuição do índice de vazios, sem ocorrer mudanças em seu ângulo de atrito e coesão.

Possivelmente, esta hipótese é válida para este tipo de solo (compactados ou naturais pouco cimentados). Porém, em solos cimentados, as fases de cisalhamento iniciais podem quebrar as ligações por cimentação da amostra, modificando a sua estrutura interna e, consequentemente, modificando também os parâmetros de resistência. 


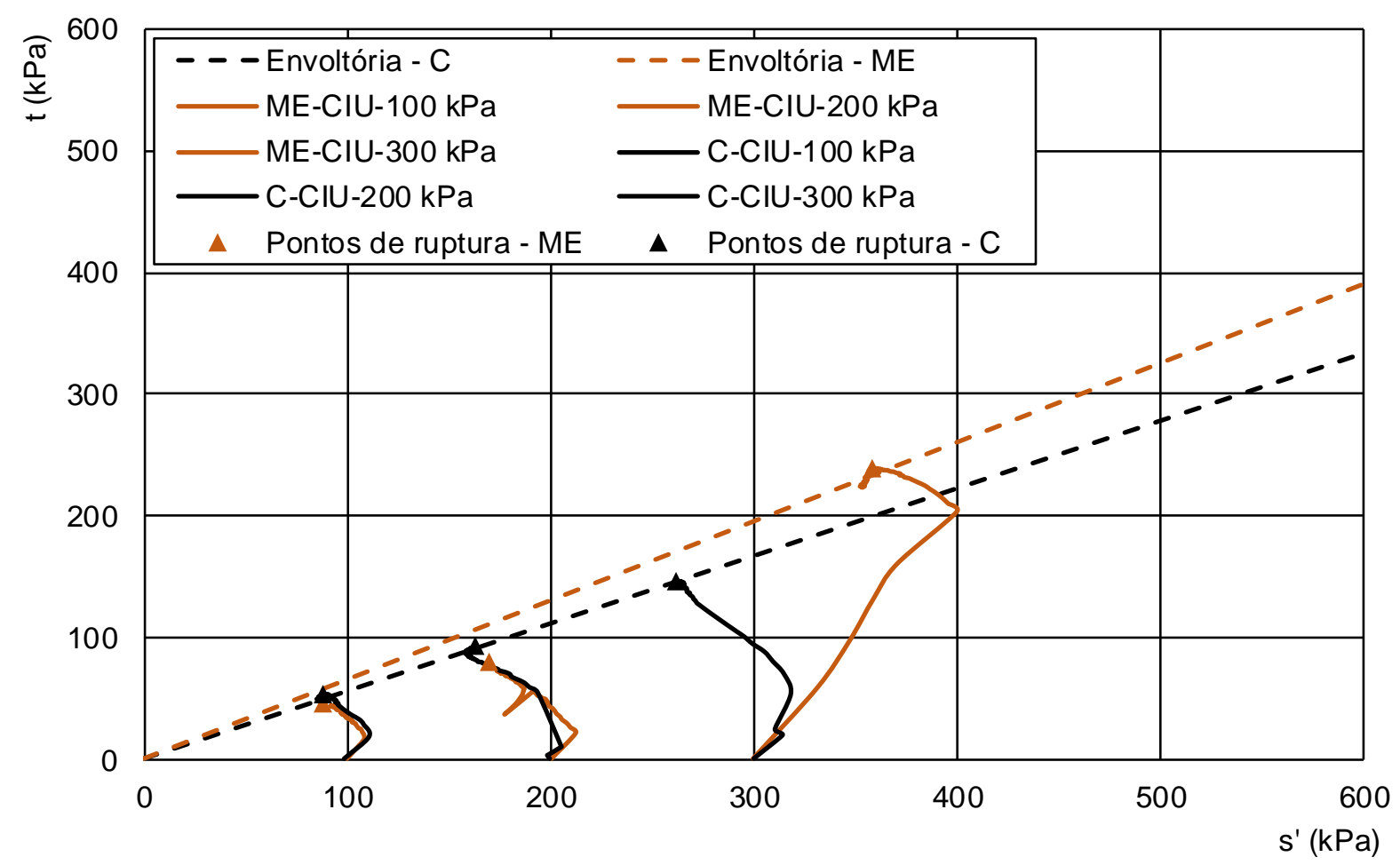

Figura 94. Comparação das trajetórias de tensões obtidas nos ensaios A e B

\subsubsection{Parâmetros de resistência}

A Figura 95 traz os círculos de Mohr de ruptura dos ensaios A e B. Os círculos plotados no ensaio $B$ correspondem ao ponto de paralisação nos dois primeiros estágios de cisalhamento e não aos pontos de ruptura interpretados.

A Tabela 15 apresenta os parâmetros do ensaio no momento da ruptura e os parâmetros de resistência interpretados.

O ensaio convencional resultou nos seguintes parâmetros de resistência: $\mathrm{c}^{\prime}=0 \mathrm{kPa} \mathrm{e}$ $\varphi^{\prime}=41^{\circ}$. O ensaio multi-estágio resultou em: $\mathrm{c}^{\prime}=2 \mathrm{kPa}$ e $\varphi^{\prime}=34^{\circ}$. Dessa forma, houve uma diferença de $7^{\circ}$ no ângulo de atrito estimado e de $2 \mathrm{kPa}$ na coesão.

A Tabela 16 traz os parâmetros de resistência deste solo obtidos na literatura. Nos estudos consultados, os valores de coesão variaram entre 5 e $27 \mathrm{kPa}$, com média de $16,75 \mathrm{kPa}$. O ângulo de atrito apresentou variação entre $27^{\circ}$ e $34^{\circ}$. $\mathrm{O}$ ângulo de atrito obtido no ensaio $A$ é coincidente com o ângulo de atrito máximo encontrado na literatura. $\mathrm{O}$ ângulo obtido no ensaio $\mathrm{B}$ é superior à média da literatura. 


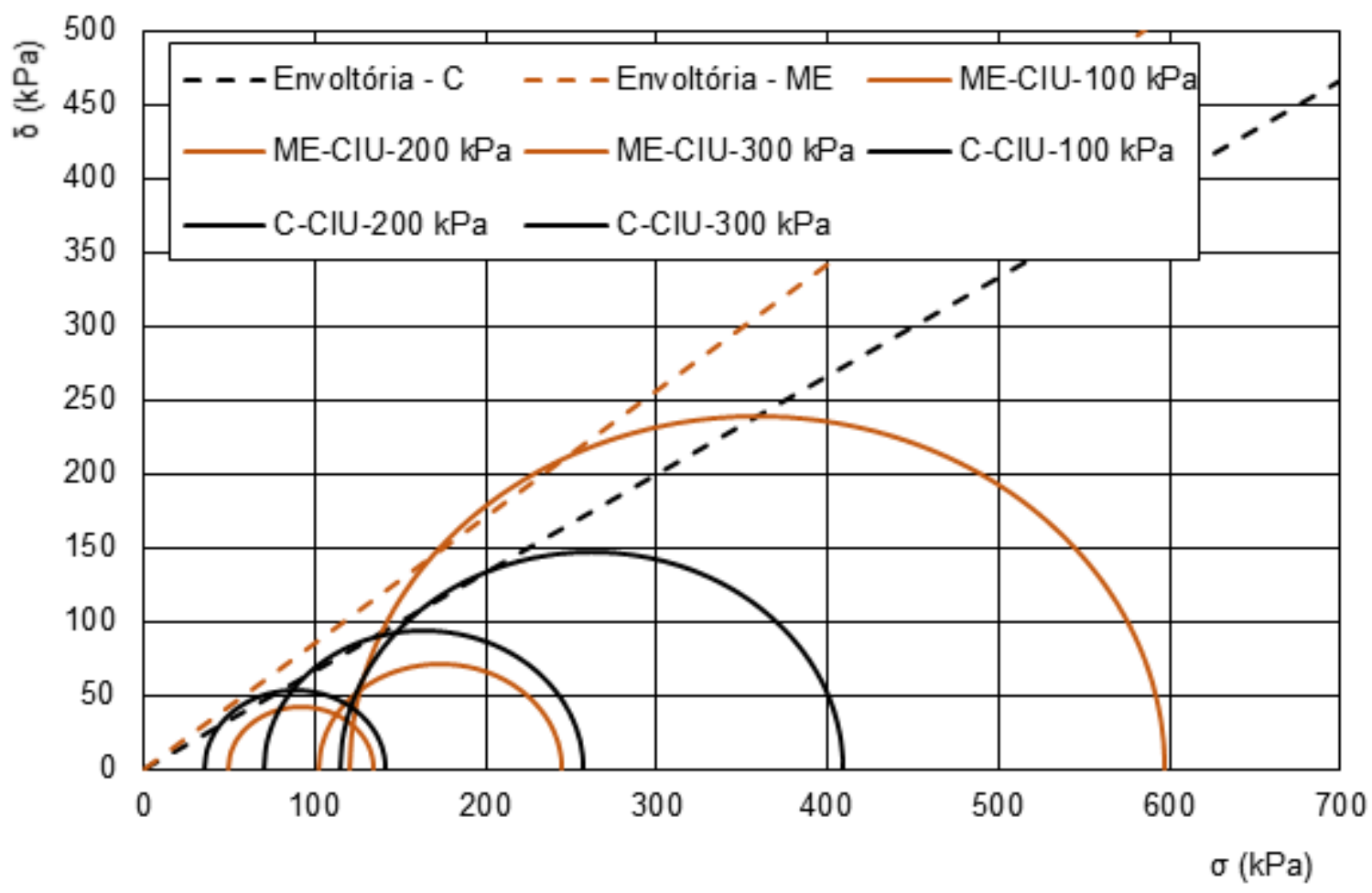

Figura 95. Círculos de Mohr obtidos nos ensaios A e B

Tabela 15. Parâmetros de resistência e síntese das condições do ensaio nos pontos de ruptura.

\begin{tabular}{|c|c|c|c|c|c|c|c|c|c|c|}
\hline \multicolumn{11}{|c|}{ PONTOS DE RUPTURA INFERIDOS - ENSAIO MULTI-ESTÁGIO } \\
\hline & $\varepsilon_{\mathrm{a}}$ & $\mathbf{q}$ & $\Delta \mathbf{u}$ & sig3' & q/sig3' & sig1' & $\mathbf{s}^{\prime}$ & $\mathbf{t}$ & $c^{\prime}$ & $\phi^{\prime}$ \\
\hline $100 \mathrm{kPa}$ & 3.50 & 90.00 & 57.00 & 43.00 & 2.09 & 133.00 & 88.00 & 45.00 & & \\
\hline $200 \mathrm{kPa}$ & 4.50 & 160.00 & 110.00 & 90.00 & 1.78 & 250.00 & 170.00 & 80.00 & 0 & 41 \\
\hline $300 \mathrm{kPa}$ & 6.75 & 477.50 & 180.00 & 120.00 & 3.98 & 597.50 & 358.75 & 238.75 & & \\
\hline \multicolumn{11}{|c|}{ PONTOS DE RUPTURA INFERIDOS - ENSAIO CONVENCIONAL } \\
\hline & $\varepsilon_{a}$ & $\mathbf{q}$ & $\Delta \mathbf{u}$ & sig3' & q/sig3' & sig1' & $\mathbf{s}^{\prime}$ & $\mathbf{t}$ & $c^{\prime}$ & $\phi^{\prime}$ \\
\hline $100 \mathrm{kPa}$ & 7.94 & 106.97 & 64.00 & 35.00 & 3.06 & 141.97 & 88.49 & 53.49 & & \\
\hline $200 \mathrm{kPa}$ & 10.82 & 186.39 & 130.00 & 70.00 & 2.66 & 256.39 & 163.19 & 93.19 & 2 & 34 \\
\hline $300 \mathrm{kPa}$ & 6.76 & 293.36 & 185.00 & 115.00 & 2.55 & 408.36 & 261.68 & 146.68 & & \\
\hline
\end{tabular}


Tabela 16. Parâmetros de resistência do solo compactado: comparativo com a literatura

\begin{tabular}{|c|c|c|c|c|}
\hline & $\begin{array}{l}\text { Tipo de } \\
\text { ensaio }\end{array}$ & Tipo de amostra & c ou c' (kPa) & $\varphi$ ou $\varphi^{\prime}\left({ }^{\circ}\right)$ \\
\hline \multirow{4}{*}{ Oliveira (2004) } & \multirow{3}{*}{ CAU } & Compactada - umidade ótima & 12 & 32 \\
\hline & & Compactada - ramo seco & 5 & 34 \\
\hline & & Compactada - ramo úmido & 9 & 32 \\
\hline & CAD & Compacta - umidade ótima & 12 & 30 \\
\hline \multirow{3}{*}{ Guzmán (2013) } & \multirow{3}{*}{$\mathrm{ClU}$} & Compactada - umidade ótima & 21.4 & 29 \\
\hline & & Compactada - ramo úmido & 17.6 & 31 \\
\hline & & Compactada - ramo úmido & 15.5 & 28 \\
\hline \multirow{3}{*}{ Orlando (2015) } & \multirow{3}{*}{$\mathrm{ClU}$} & Compactada - umidade ótima & 27 & 27 \\
\hline & & Compactada - ramo seco & 27 & 29 \\
\hline & & Compactada - ramo úmido & 21 & 27 \\
\hline \multirow{2}{*}{ Estudo atual } & \multirow{2}{*}{$\mathrm{ClU}$} & C - Compactada - umidade ótima & 2 & 34 \\
\hline & & ME - Compactada - umidade ótima & 0 & 41 \\
\hline
\end{tabular}

\subsubsection{Parâmetros de deformabilidade}

A Figura 96 apresenta a comparação dos módulos de resistência secantes obtidos nos ensaios $A$ e $B$. Nos ensaios multi-estágios foram obtidos módulos a partir de $0.03 \%$ de deformação e nos ensaios convencionais os módulos foram medidos a partir de $0.15 \%$ de deformação axial. Esta diferença se deve à programação do ensaio, devido à limitação do número de leituras permitidas pelo software utilizado e a extensão do ensaio.

Observa-se que os módulos obtidos no primeiro estágio (com tensão confinante efetiva de $100 \mathrm{kPa}$ ) nos ensaios $\mathrm{A}$ e B apresentam boa correlação. Excluindo a primeira leitura do ensaio convencional, as medidas se sobrepõem no gráfico, como era esperado.

No segundo estágio dos ensaios (realizados com $200 \mathrm{kPa}$ ), observa-se que, de modo geral, os módulos de deformabilidade obtidos no ensaio multi-estágio apresentam valores maiores do que os obtidos no ensaio convencional. Porém, tais diferenças são baixas e tendem a diminuir com o aumento da deformação. A partir de $1.76 \%$ de deformação, os módulos são coincidentes. 


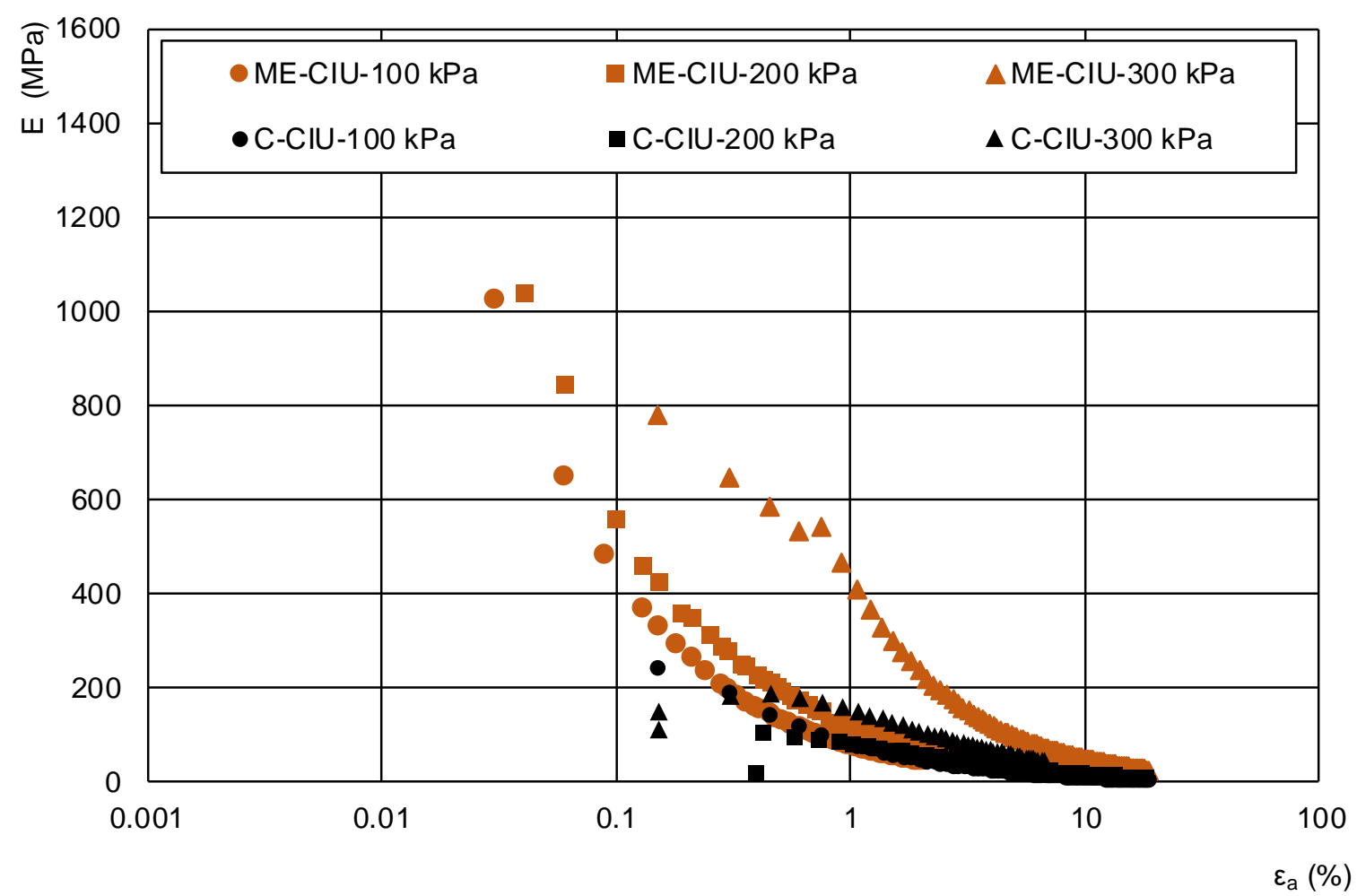

Figura 96. Comparação entre módulos de deformabilidade secantes obtidos nos ensaios A e B

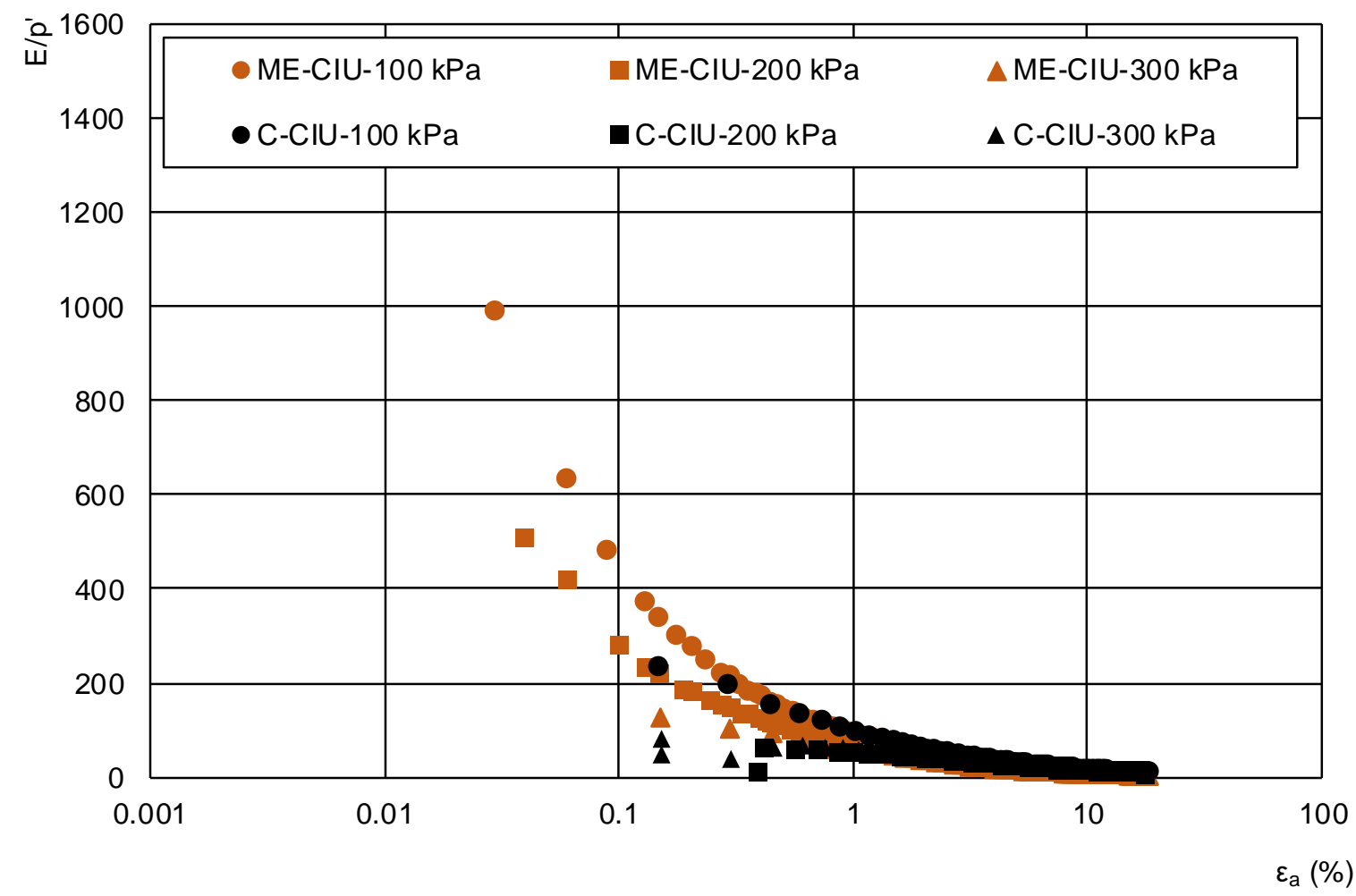

Figura 97. Módulos de deformabilidade secantes normalizados por p' obtidos nos ensaios A e B 
No terceiro estágio não há correlação entre os módulos obtidos nos ensaios A e B. Os módulos obtidos no ensaio multi-estágio nesta etapa são significamente maiores do que os obtidos no ensaio convencional. Na Figura 97, onde os módulos de deformabilidade são normalizados por p', os valores de $\mathrm{E}$ se sobrepõem a partir de $0.6 \%$ de deformação.

As diferenças observadas nos módulos presentes na Figura 96 demonstram que a amostra tornou-se gradualmente mais rígida ao longo de ensaio multi-estágio, quando comparamos com os módulos obtidos nos ensaios convencionais. Porém, na Figura 97, observa-se que é os módulos de deformação normalizados apresentam boa correlação.

\subsection{Avaliação de ensaios multi-estágios em amostras indeformadas}

A avaliação da técnica multi-estágio em amostras indeformadas é dificultada pela elevada heterogeneidade das amostras, que muitas vezes não permite a comparação direta dos resultados com os obtidos em ensaios convencionais. Devido esta dificuldade, foi necessária a execução de dois ensaios convencionais (ensaios $D$ e E) e quatro ensaios multi-estágios em amostras indeformadas (ensaios $\mathrm{G}, \mathrm{H}, \mathrm{I}$ e J) para uma avaliação consistente da técnica.

A Figura 98 apresenta as trajetórias de tensões obtidas nestes ensaios. Como pode ser observado, as amostras apresentaram comportamentos distintos e diferentes parâmetros de ruptura foram obtidos. A Tabela 17 apresenta um resumo dos parâmetros de resistência obtidos neste solo.

Para facilitar as análises dos dados, os ensaios que apresentaram comportamentos semelhantes foram analisados separadamente, permitindo uma melhor avaliação da técnica multi-estágio. Dessa forma, foram os seguintes ensaios foram analisados em conjunto: Ensaios D versus $\mathrm{G}$; ensaios $\mathrm{E}$ versus $\mathrm{H}$; e ensaios $\mathrm{D}$ versus $\mathrm{F}$ e I. 

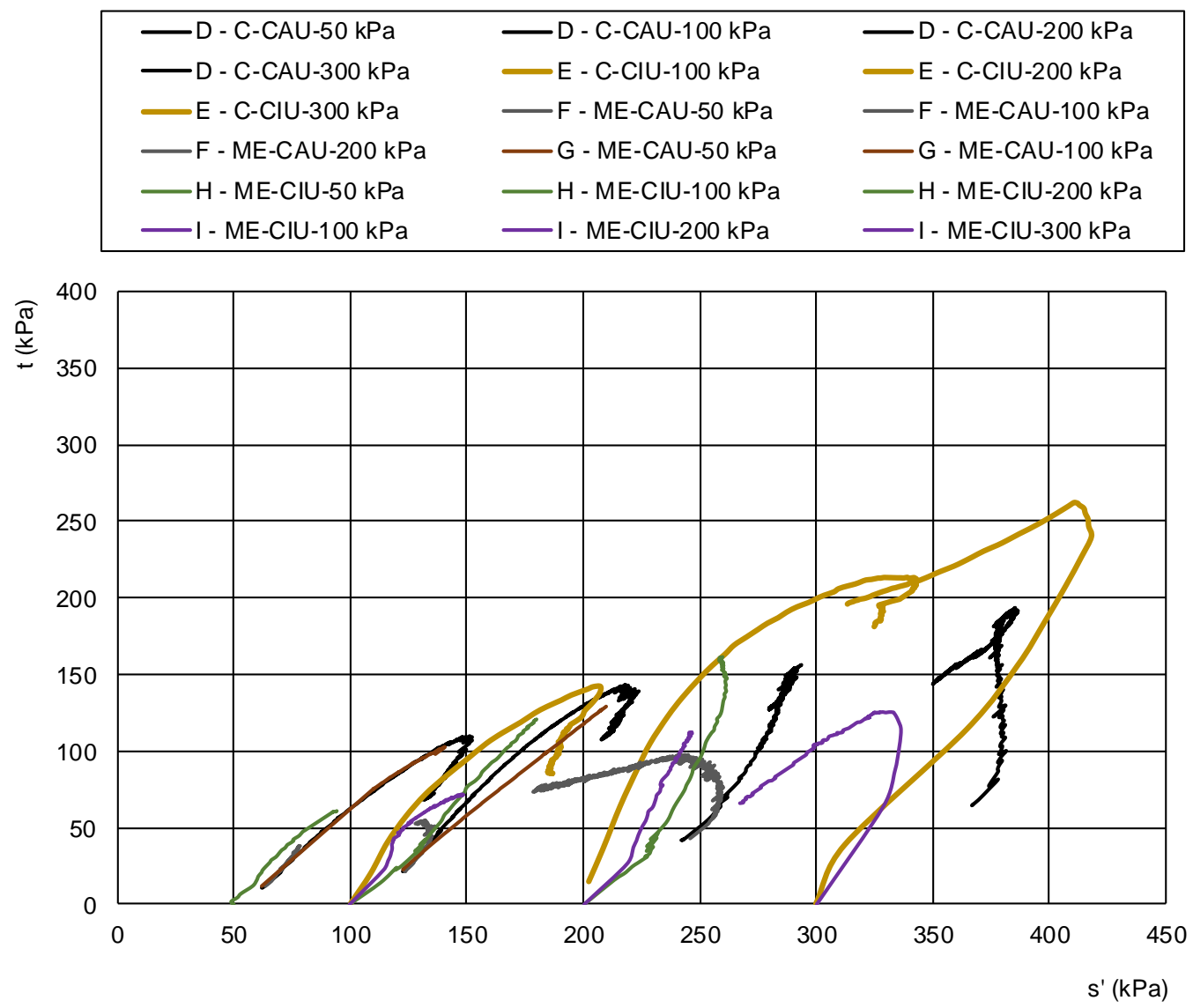

Figura 98. Comparativo das trajetórias de tensões obtidas nos ensaios D, F, G, H e I

Tabela 17. Síntese dos parâmetros de resistência obtidos em amostras indeformadas

\begin{tabular}{|c|c|c|c|c|}
\hline ID & Tipo de Ensaio & Ensaio & $c^{\prime}$ & $\varphi^{\prime}$ \\
\hline \multirow{4}{*}{ D } & & C-CAU-50 kPa & \multirow{4}{*}{61} & \multirow{4}{*}{20} \\
\hline & Convoncional & C-CAU-100 kPa & & \\
\hline & Gourverictudial & C-CAU-200 kPa & & \\
\hline & & C-CAU-300 kPa & & \\
\hline \multirow{3}{*}{$\mathrm{E}$} & & C-CIU-100kPa & \multirow{3}{*}{29} & \multirow{3}{*}{35} \\
\hline & Convencional & C-CIU-200kPa & & \\
\hline & & C-CIU-300kPa & & \\
\hline \multirow{3}{*}{$\mathrm{F}$} & & ME-CAU-50 kPa & \multirow{3}{*}{12} & \multirow{3}{*}{21} \\
\hline & Multi-estágio & ME-CAU-100 kPa & & \\
\hline & & ME-CAU-200 kPa & & \\
\hline \multirow{2}{*}{$\mathrm{G}$} & Multi-estágio & ME-CAU-50 kPa & \multirow{2}{*}{55} & \multirow{2}{*}{23} \\
\hline & & ME-CAU-100 kPa & & \\
\hline \multirow{3}{*}{$\mathrm{H}$} & & ME-CIU-50 kPa & \multirow{3}{*}{13} & \multirow{3}{*}{37} \\
\hline & Multi-estágio & ME-CIU-100 kPa & & \\
\hline & & ME-CIU-200 kPa & & \\
\hline \multirow{3}{*}{1} & & ME-CIU-100 kPa & \multirow{3}{*}{28} & \multirow{3}{*}{19} \\
\hline & Multi-estágio & ME-CIU-200 kPa & & \\
\hline & & ME-CIU-300 kPa & & \\
\hline
\end{tabular}




\subsubsection{Ensaios D e G}

A Figura 99 apresenta as curvas de tensão-deformação e de variação de poropressões dos ensaios $G$ e $D$. Como explicitado no item 3.5 o ensaio $G$ foi realizado apenas com tensões de adensamento de 50 e $100 \mathrm{kPa}$, pois este corpo de prova foi utilizado para as análises microscópicas. Para facilitar a visualização, apenas os dois primeiros estágios do ensaio $D$ foram apresentados no gráfico a seguir.
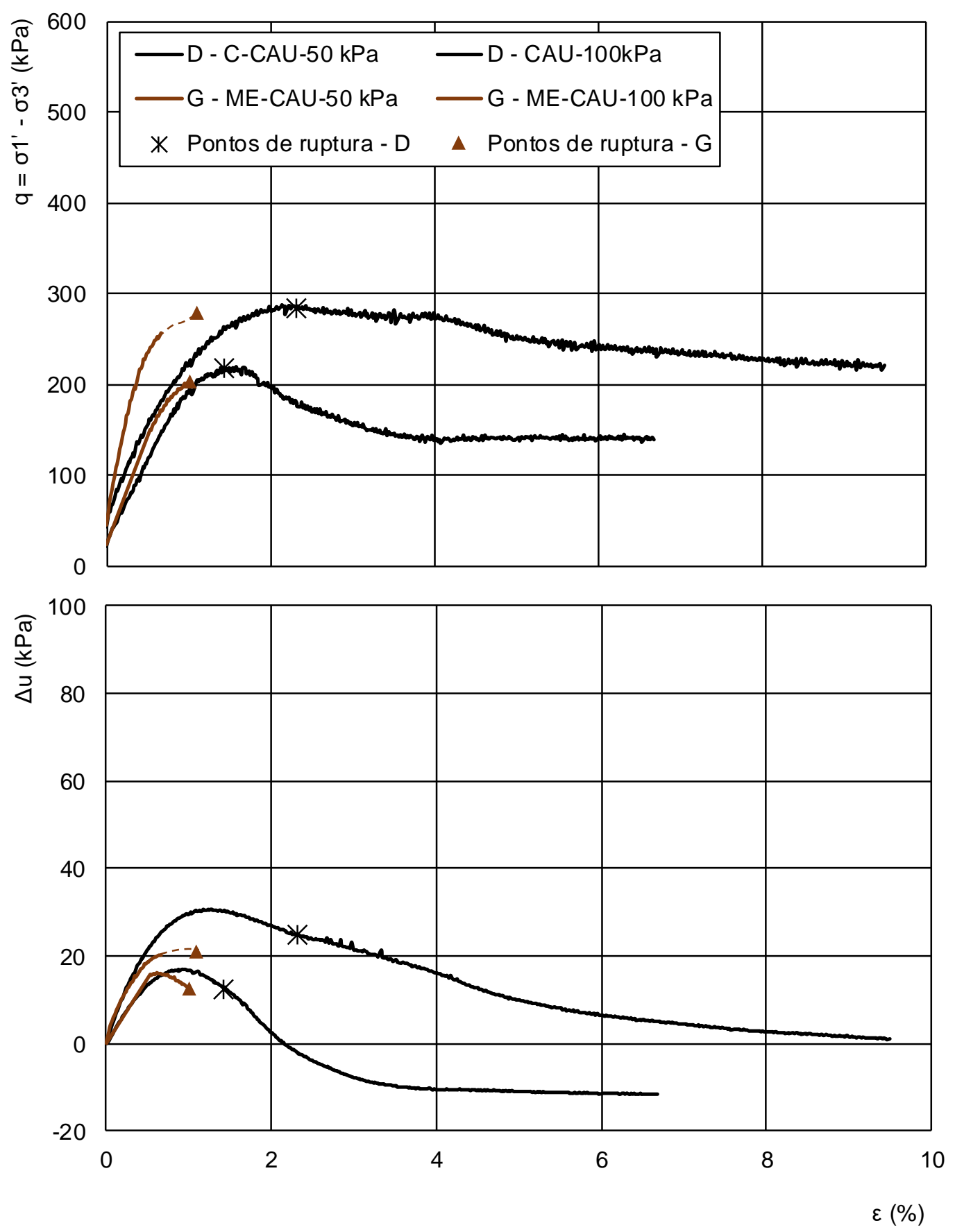

Figura 99. Gráficos de tensão-deformação e variação de poro-pressões dos ensaios G e D 
A Tabela 18 apresenta os parâmetros de ensaio no momento da ruptura. As diferenças entre as tensões desviadoras de ruptura foram pequenas. Nos ensaios realizados com $50 \mathrm{kPa}$ de confinante, a diferença entre as tensões de ruptura foi de $13.5 \mathrm{kPa}$. No ensaio de $100 \mathrm{kPa}$, esta diferença cai para $4 \mathrm{kPa}$. As diferenças entre as poropressões na ruptura também foram baixas, chegando a ser nula no ensaio de $50 \mathrm{kPa}$.

A Figura 100 apresenta as trajetórias de tensões e as envoltórias de tensão obtidas. Observa-se menor geração de poro-pressões ao longo ensaio multi-estágio. Este comportamento foi observado por diversos autores (e.g. Parry e Nadajarah, 1973, Nambiar et al, 1985).

Tabela 18. Dados dos ensaios D e G na ruptura

\begin{tabular}{|c|c|c|c|c|c|c|c|c|}
\hline \multicolumn{9}{|c|}{ PONTOS DE RUPTURA INFERIDOS - G } \\
\hline & $\varepsilon_{\mathrm{a}}$ & q & $\Delta \mathbf{u}$ & sig3' & q/sig3' & sig1' & $\mathbf{s}^{\prime}$ & $\mathbf{t}$ \\
\hline $50 \mathrm{kPa}$ & 1.00 & 205.00 & 12.50 & 38.10 & 5.38 & 243.10 & 140.60 & 102.50 \\
\hline $100 \mathrm{kPa}$ & 1.10 & 280.00 & 21.00 & 79.50 & 3.52 & 359.50 & 219.50 & 140.00 \\
\hline \multicolumn{9}{|c|}{ PONTOS DE RUPTURA INFERIDOS - D } \\
\hline & $\varepsilon_{\mathrm{a}}$ & q & $\Delta \mathbf{u}$ & sig3' & q/sig3' & sig1' & $\mathbf{s}^{\prime}$ & $t$ \\
\hline $50 \mathrm{kPa}$ & 1.42 & 218.50 & 12.50 & 38.70 & 5.65 & 257.20 & 148.00 & 109.30 \\
\hline $100 \mathrm{kPa}$ & 2.31 & 284.00 & 24.70 & 76.00 & 2.81 & 360.00 & 218.00 & 142.00 \\
\hline
\end{tabular}

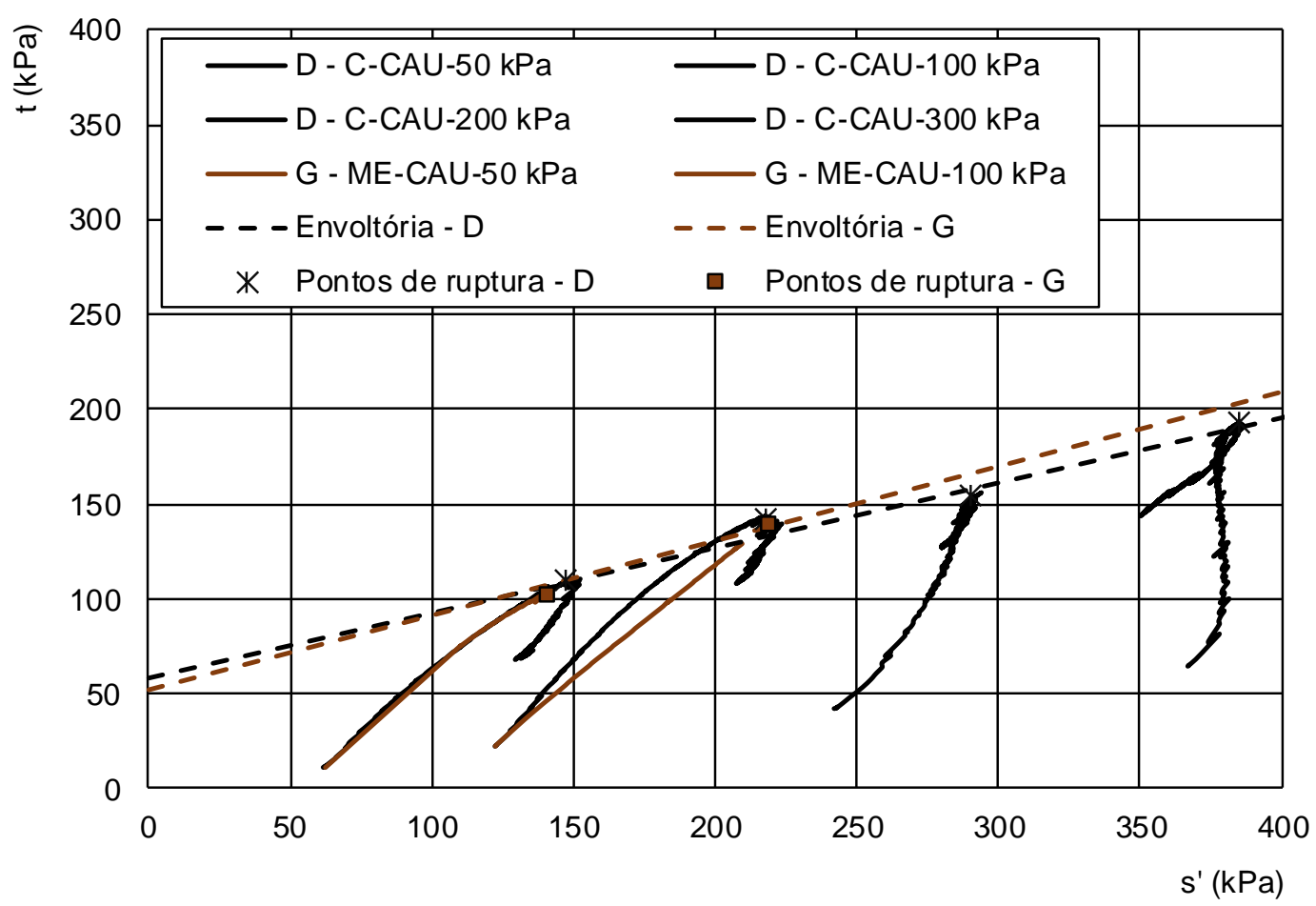

Figura 100. Trajetórias de tensões resultantes dos ensaios D e G 
As diferenças dos parâmetros de resistência obtidos foram de $6 \mathrm{kPa}$ de coesão e $3^{\circ}$ no ângulo de atrito, representando uma diferença de cerca de $10 \%$ dos valores totais. Em relação aos módulos de deformabilidade, observa-se comportamento semelhante ao ocorrido nas amostras compactadas. O gráfico da Figura 101 apresenta os módulos de deformação secantes pela deformação axial. Os dados iniciais do primeiro estágio do ensaio $G$ não foram salvos, devido problemas técnicos.

Os módulos obtidos no primeiro estágio do ensaio multi-estágio são coincidentes com os obtidos no ensaio convencional. Já o segundo estágio do ensaio multi-estágio apresenta módulos de deformação consideravelmente mais elevados ensaio multiestágio, demonstrando que há aumento de rigidez da amostra devido a etapa inicial de cisalhamento. Porém, os módulos de deformação normalizados por p' (

Figura 102) tendem a se igualar.

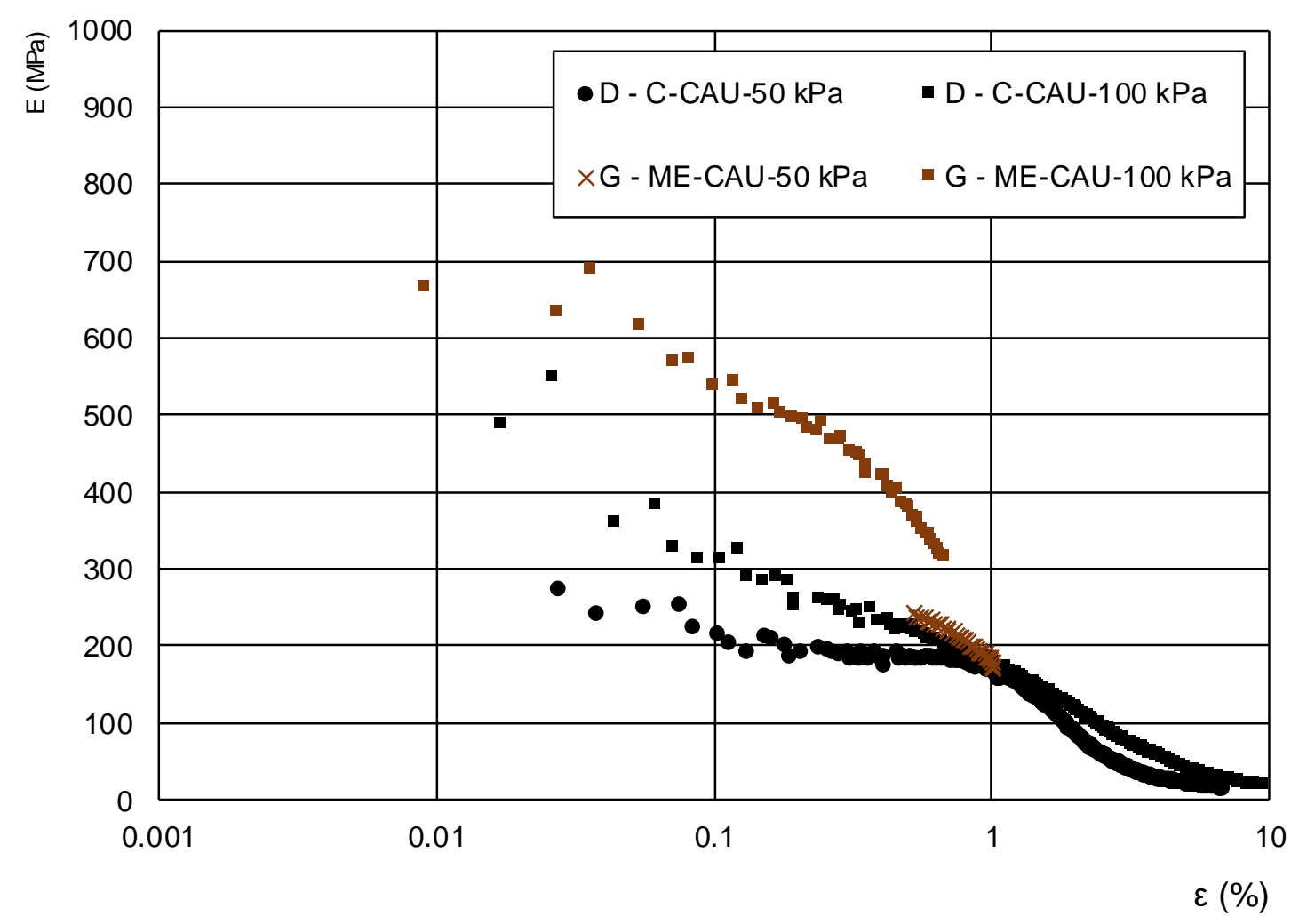

Figura 101. Módulos de deformabilidade obtidos no ensaio G e D 


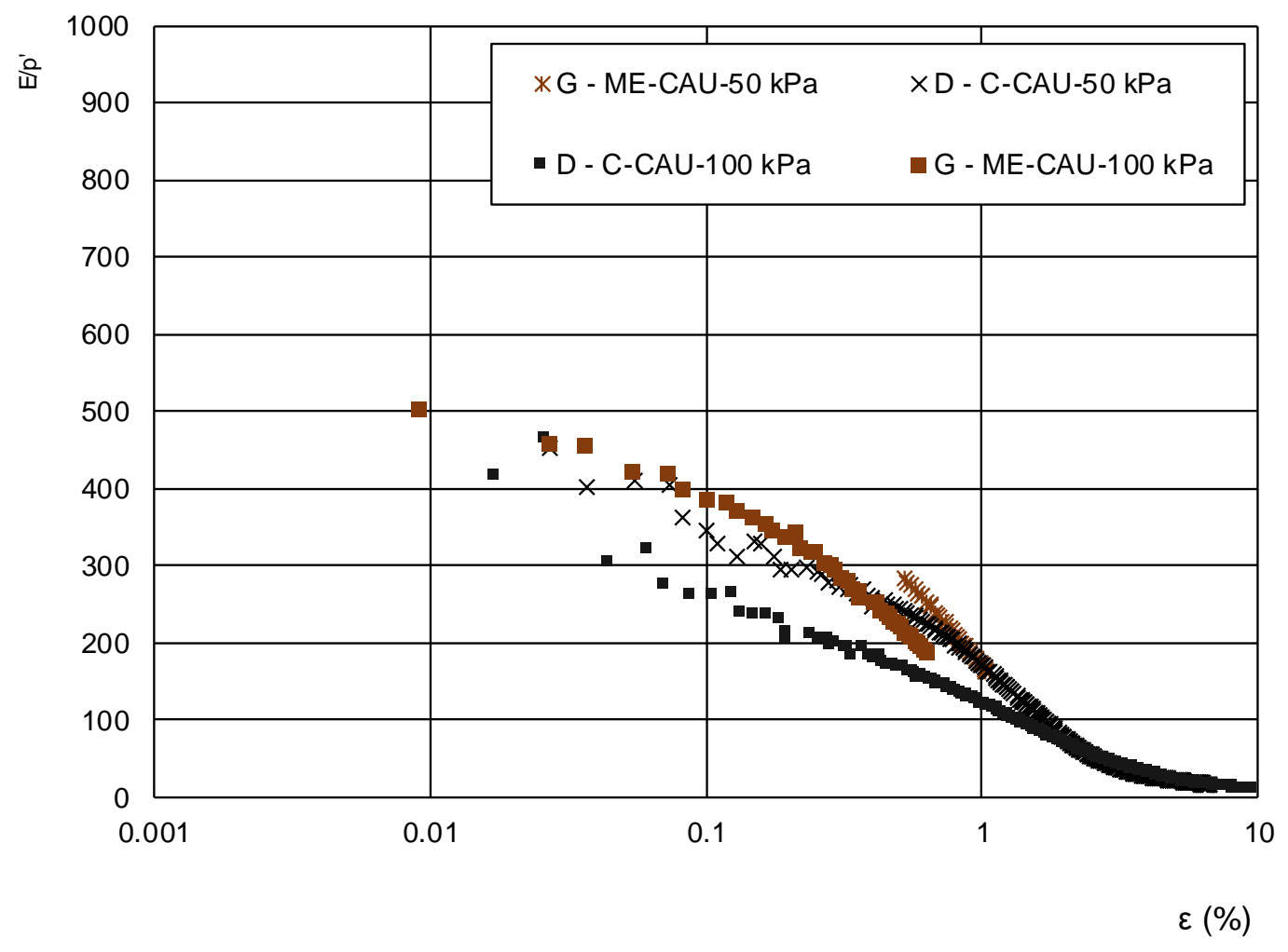

Figura 102. Módulos de deformabilidade normalizados por p' obtidos nos ensaios D e G

A Figura 103 apresenta o gráfico tensão-deformação, sem normalização da deformação inicial. Neste gráfico observa-se que o aumento da rigidez ocorre apenas no trecho já deformado no estágio anterior. Esta mudança no comportamento da amostra pode ser influenciada tanto pela fase de carregamento e cisalhamento axial, uma vez que a amostra não apresenta comportamento perfeitamente elástico. Porém, observa-se que após este trecho, a amostra apresenta o mesmo comportamento que uma amostra que não sofreu carregamento axial previamente. 


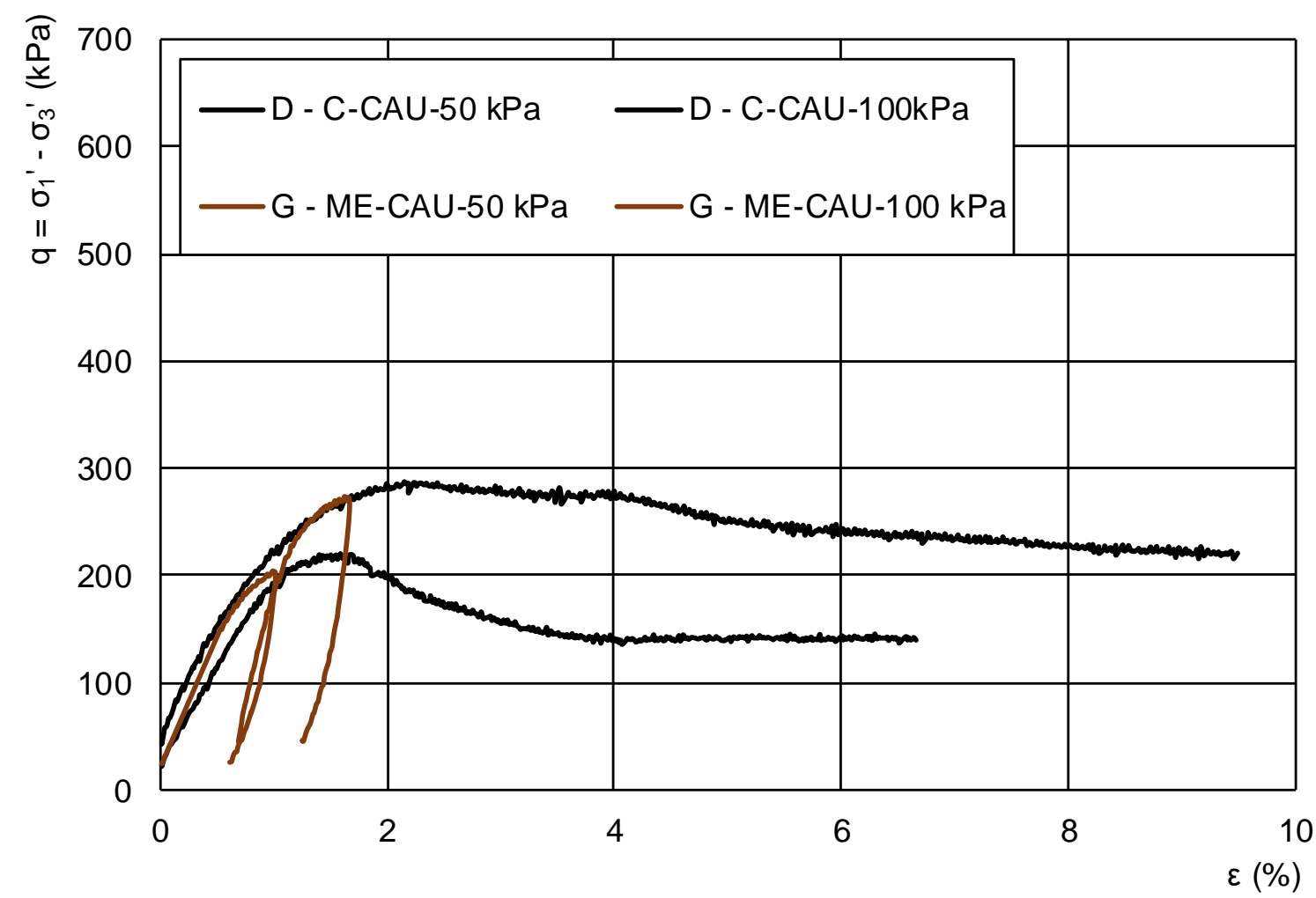

Figura 103. Curvas de tensão-deformação dos ensaios D e G

\subsubsection{Ensaios E e H}

As curvas de tensão-deformação e de variação de poro-pressões obtidas nos ensaios E e H estão apresentadas na Figura 104. Neste gráfico, as curvas de 100 e $200 \mathrm{kPa}$ podem ser comparadas. $\mathrm{O}$ ensaio multi-estágio $(\mathrm{H})$ apresentou menores tensões desviadoras de ruptura que o ensaio convencional $(E)$, a diferença de tensão de ruptura no ensaio de $100 \mathrm{kPa}$ foi de $40 \mathrm{kPa}$ e no ensaio de $200 \mathrm{kPa}$ foi $103 \mathrm{kPa}$. Em relação ao comportamento da curva, observa-se que em baixas deformações as tensões desviadoras no ensaio multi-estágio são ligeiramente maiores. Comparando a curvatura das curvas, nota-se maior rigidez do corpo de prova no início dos ensaios multi-estágios.

Apesar das diferenças no comportamento tensão-deformação, o comportamento das poro-pressões nos dois tipos de ensaios foi semelhante. Observa-se que o aumento das poro-pressões é ligeiramente maior no ensaio multi-estágio no início das fases de cisalhamento. No gráfico da Figura 105 vê-se que as curvas tendem a se aproximar no decorrer do ensaio, sobrepondo-se próximo ao pico de poro-pressões. 
A trajetória de tensões, presente na Figura 105, mostra que a trajetória do ensaio multi-estágio fica à direita da trajetória de tensões do ensaio convencional correspondente, como ocorrido com as demais comparações realizadas.
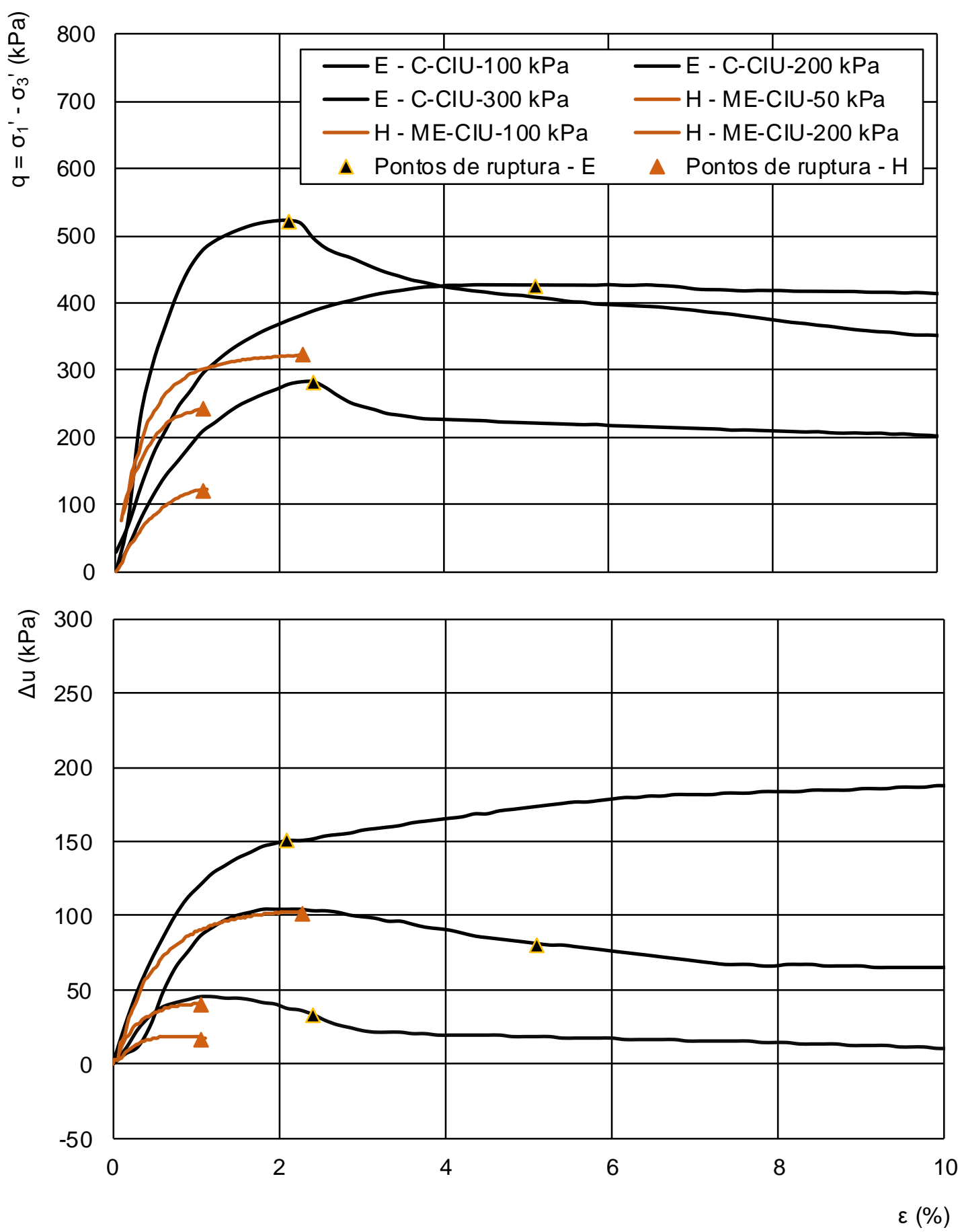

Figura 104. Curvas de tensão-deformação e variação de poro-pressões dos ensaios E e H

Apesar de ocorrer maior mobilização de tensões no ensaio convencional, os pontos de ruptura dos dois tipos de ensaio ocorrem praticamente na mesma envoltória de 
ruptura. A Tabela 20 apresenta os parâmetros obtidos. Houve diferença de $2^{\circ}$ no ângulo de atrito e de $16 \mathrm{kPa}$ no ângulo de atrito. A Figura 106 apresenta os círculos de Mohr obtidos, apresentando a semelhança nas envoltórias obtidas.

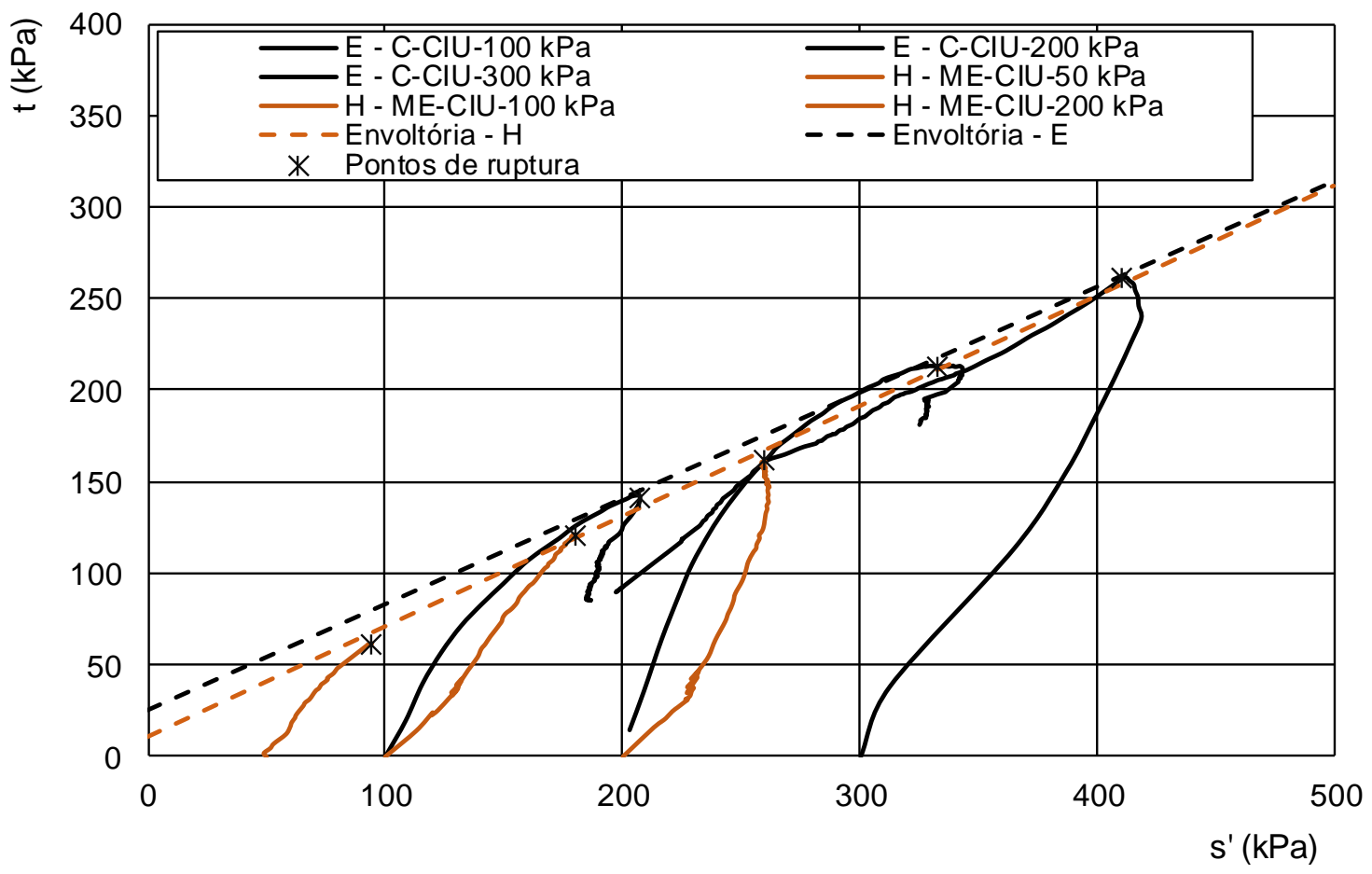

Figura 105. Trajetórias de tensões obtidas nos ensaios E e H

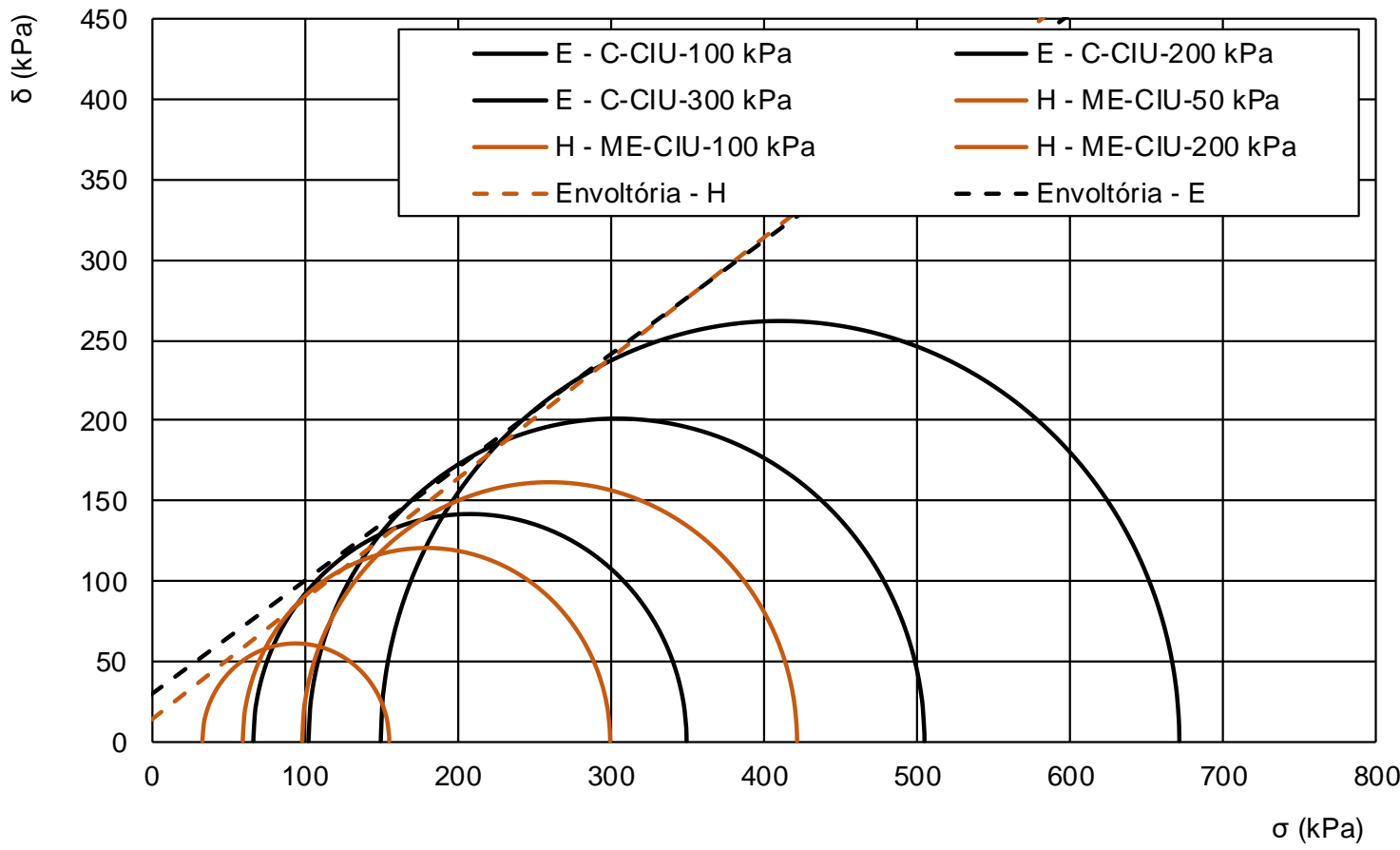

Figura 106. Círculos de Mohr de ruptura obtidos nos ensaios E e H 
A Figura 107 apresenta os módulos de deformabilidade secantes obtidos nos ensaios $\mathrm{E}$ e H, para os ensaios de 100 e $200 \mathrm{kPa}$. Os módulos obtidos em ambos os ensaios foram parecidos. Porém, para baixas deformações, os módulos de deformabilidade normalizados por p' do ensaio multi-estágio foram maiores do que os obtidos no ensaio convencional como mostrado na Figura 104. Este fato indica que ocorre enrijecimento do corpo de prova no ensaio multi-estágio. Este enrijecimento influência o cálculo dos módulos de deformabilidade apenas no início do ensaio. Com o aumento da deformação, há tendência de aproximação das curvas dos módulos normalizados.

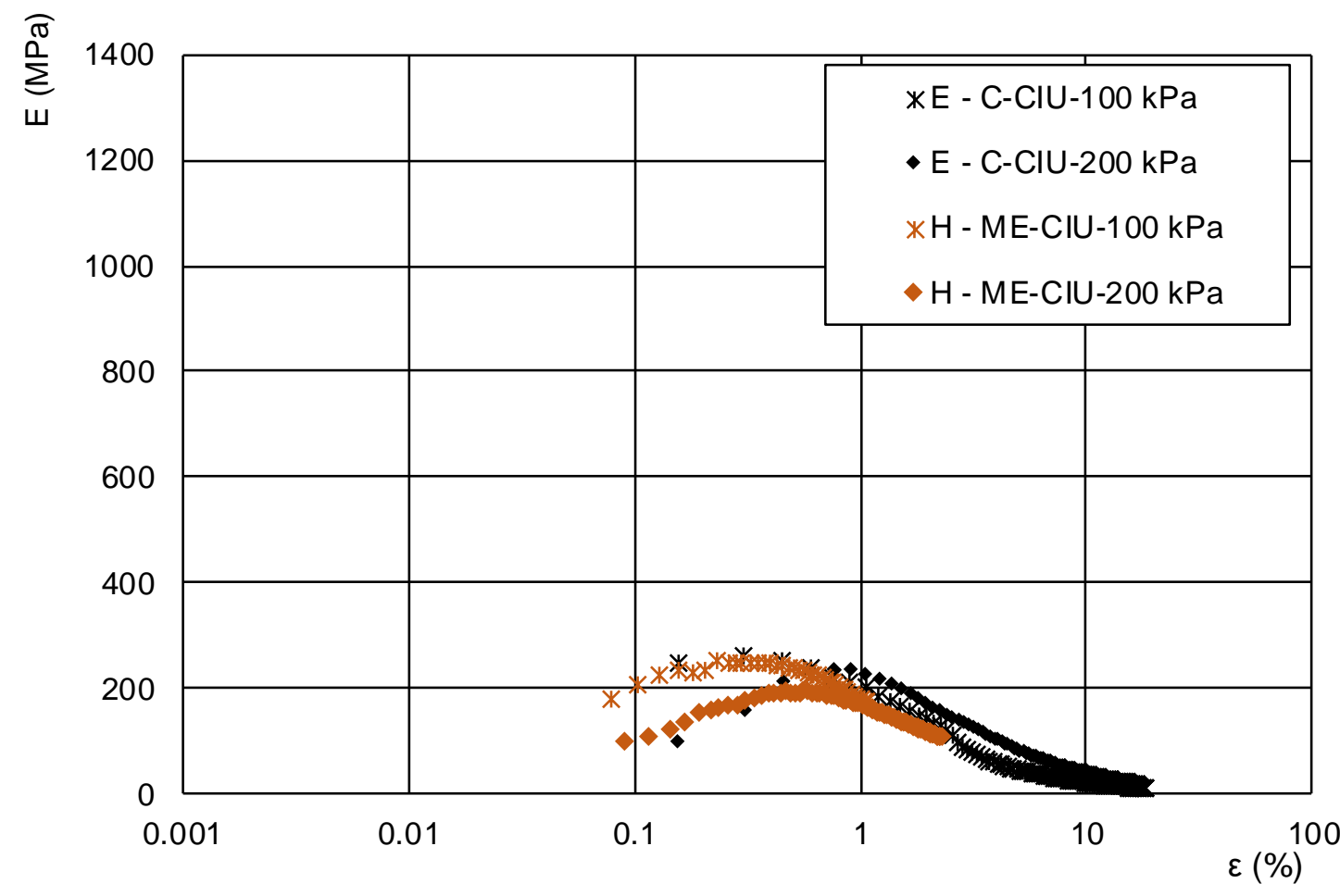

Figura 107. Módulos de deformabilidade secantes obtidos nos ensaios E e H 


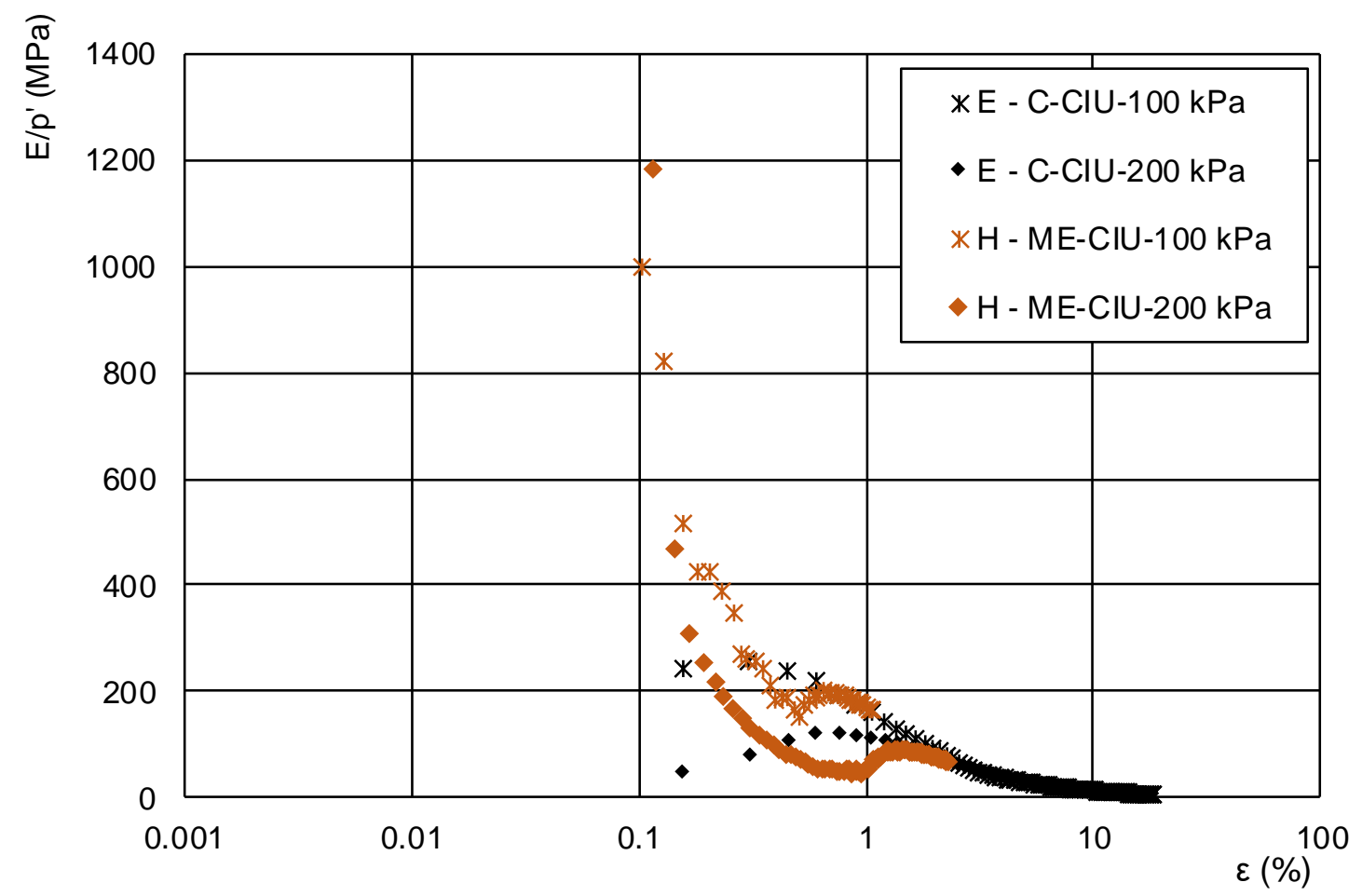

Figura 108. Comparativo dos módulos de deformabilidade secantes obtidos nos ensaios $E$ e H

\subsubsection{Ensaios D, F e I}

A Figura 109 apresenta as curvas de tensão-deformação do ensaio convencional D e dos ensaios multi-estágios $\mathrm{F}$ e I. Como pode ser observado, os níveis de tensões atingidos pelos ensaios foram distintos. Os ensaios multi-estágio $\mathrm{F} \mathrm{e} \mathrm{I}$ apresentaram tensões de ruptura consideravelmente menores do que o ensaio convencional $\mathrm{D}$.

As trajetórias de tensões dos ensaios, apresentadas na Figura 110, indicam que os ensaios multi-estágios apresentaram comportamento semelhante e as envoltórias de ruptura obtidas nestes ensaios apresentam boa correlação. Os parâmetros de ruptura apresentaram uma diferença de $2^{\circ}$ no ângulo de ruptura e uma diferença de $16 \mathrm{kPa}$.

Observa-se que as envoltórias obtidas nos ensaios multi-estágios apresentam-se paralelizadas com a envoltória do ensaio convencional D. Ou seja, os ensaios apresentam ângulos de atritos semelhantes, porém, com grandes variações na coesão. Provavelmente, trata-se de uma zona menos coesa do solo que não foi ensaiada nos ensaios convencionais. Parâmetros de resistência correlacionáveis com ensaios $\mathrm{F}$ e I foram obtidos em ensaios convencionais por Vieira (1999). 

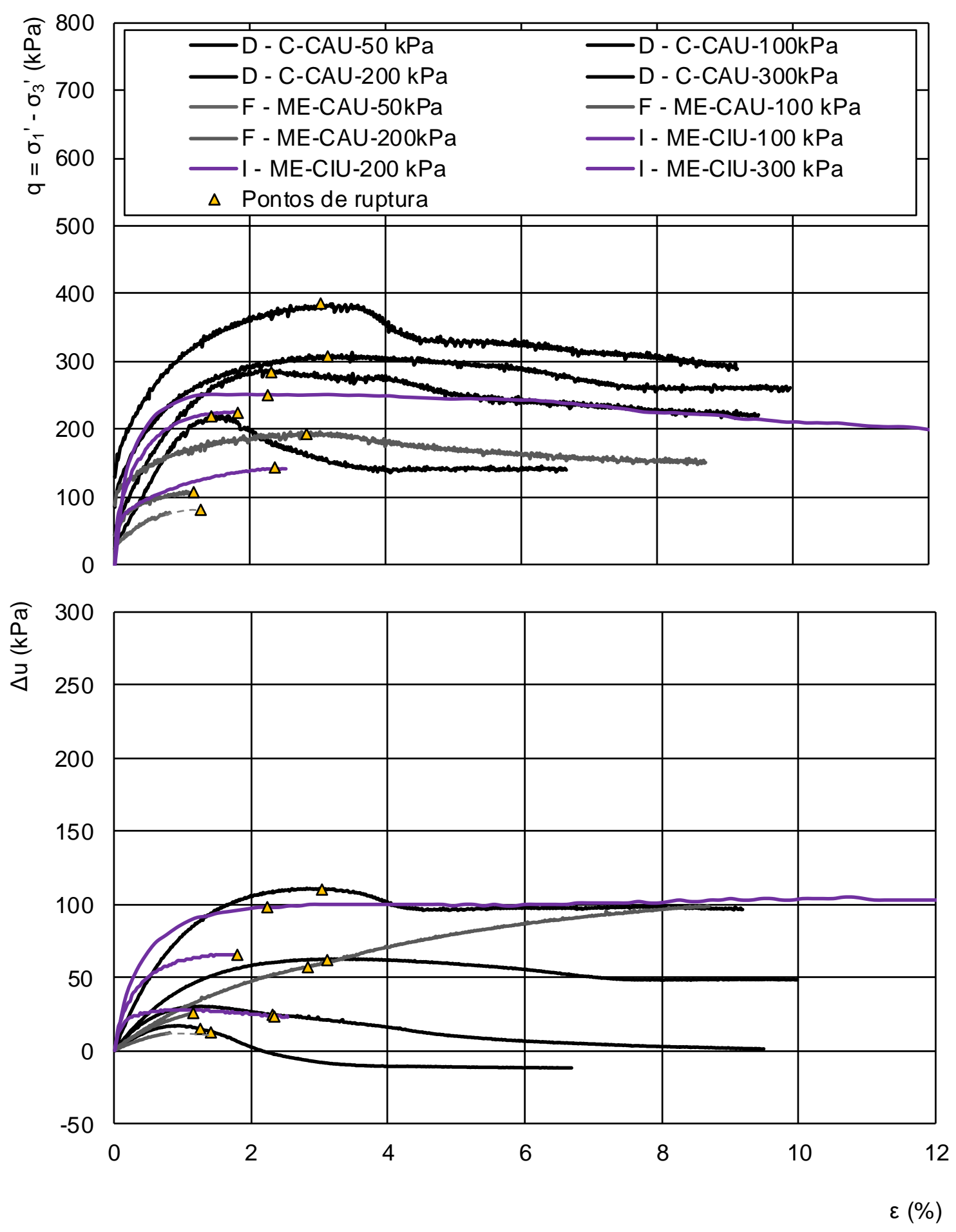

Figura 109. Curvas de tensão-deformação e curvas de variação de variação de poro-pressões versus deformação axial obtidas nos ensaios $\mathrm{D}, \mathrm{F}$ e I 


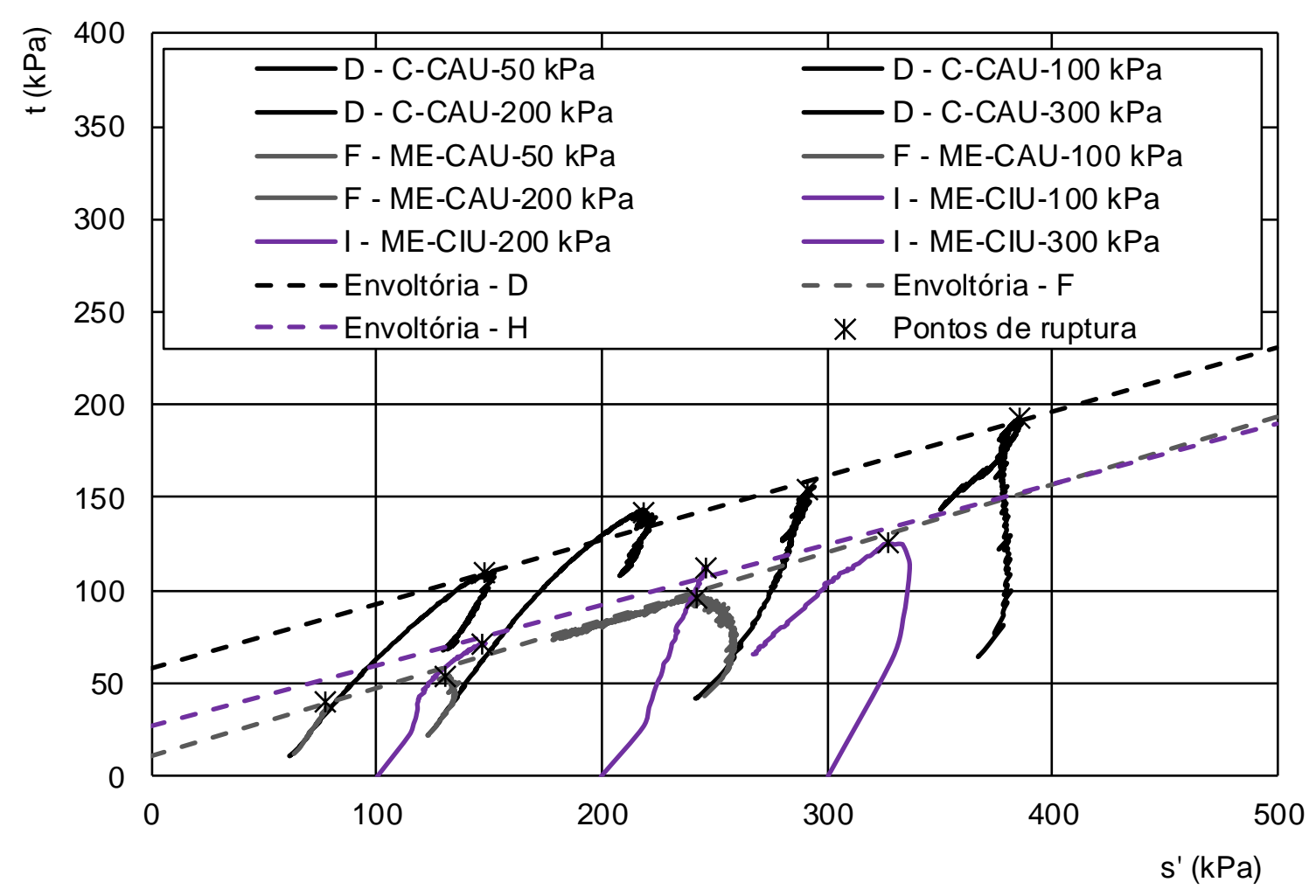

Figura 110. Trajetórias de tensões e envoltórias de ruptura obtidas nos ensaios D, F e I

\subsection{Efeito das etapas de cisalhamento intermediárias na estrutura dos corpos de prova}

A principal preocupação na execução do ensaio multi-estágio é a ação das etapas de cisalhamento iniciais e intermediárias na estrutura do corpo de prova. Alguns autores não recomendam a utilização desta técnica, pois acreditam que a amostra perde suas características iniciais ao longo do ensaio multi-estágio, resultando em parâmetros que não correspondem à realidade do maciço. Areias pouco coesas e argilas sensíveis podem ser muito afetadas pelo carregamento axial, porém ensaios triaxiais multi-estágio em solos bem cimentados e pouco sensíveis apresentaram bom desempenho em diversos estudos presentes na literatura.

Este item visa analisar os efeitos do carregamento axial na estrutura do solo residual em estudo ao longo de ensaios triaxiais. As análises foram realizadas a partir da integração de dados da literatura e dos resultados obtidos em laboratório. No item 6.4 serão discutidas as análises microestruturais realizadas a partir de imagens de MEV, salientado também as perturbações causadas pelos estágios sucessivos de cisalhamento. 


\subsubsection{Avaliação do grau de perturbação do corpo de prova após as etapas de cisalhamento iniciais}

Baseado nos experimentos de Kim e Ko (1979), que realizaram uma série de ensaios para analisar o grau de perturbação em corpos de prova de rocha (xistos e arenitos) em ensaios multi-estágios, foi realizado um ensaio com repetição da tensão de confinamento (ensaio C).

Uma amostra indeformada foi submetida à três séries de carregamento e descarregamento axial com a tensão confinante em $200 \mathrm{kPa}$. Idealmente, as tensões de ruptura estimadas a partir destes carregamentos devem ser iguais ou dentro da margem de erro do ensaio. Neste estudo, considerou-se dentro da margem de erro variações de até $10 \%$ na tensão desviadora de ruptura.

As curvas de tensão-deformação obtidas neste ensaio estão apresentas na Figura 111. Observa-se que as tensões de ruptura não foram totalmente mobilizadas nos dois estágios iniciais e, por isso, os pontos de ruptura foram estimados de acordo com a interpretação do comportamento das curvas de tensão-deformação. A Tabela 19 apresenta as tensões de ruptura inferidas.

Tabela 19. Pontos de ruptura inferidos nos três estágios do ensaio C

\begin{tabular}{ccccccccc}
\hline \multicolumn{7}{c}{ PONTOS DE RUPTURA INFERIDOS - ENSAIO C } \\
\hline & $\boldsymbol{\varepsilon}_{\mathbf{a}}$ & $\mathbf{q}$ & $\mathbf{\Delta} \mathbf{u}$ & $\mathbf{s i g 3}^{\prime}$ & $\mathbf{q} / \mathbf{s i g 3}^{\prime}$ & $\mathbf{s i g 1}^{\prime}$ & $\mathbf{s}^{\prime}$ & $\mathbf{~ t}$ \\
\hline $\mathbf{I}$ & 3.00 & 203.00 & 68.30 & 131.70 & 1.54 & 334.70 & 233.20 & 101.50 \\
\hline II & 5.50 & 179.00 & 50.20 & 149.80 & 1.19 & 328.80 & 239.30 & 89.50 \\
\hline III & 4.80 & 193.25 & 49.00 & 151.00 & 1.28 & 338.10 & 244.55 & 93.55 \\
\hline
\end{tabular}

A tensão de ruptura estimada foi mais elevada no primeiro estágio. Já a menor tensão ocorreu no segundo estágio. A diferença entre estes dois estágios é de $24 \mathrm{kPa}$, representando uma diferença de cerca de $10 \%$ na tensão de ruptura. Estas diferenças provavelmente seriam minimizadas, caso as tensões de ruptura fossem totalmente mobilizadas. No gráfico da Figura 87 vê-se que os estágios foram paralisados antes da ruptura. A diferença das tensões de ruptura entre o primeiro e o segundo estágio é de $9,75 \mathrm{kPa}$, representando $4,8 \%$.

A figura a seguir traz as trajetórias de tensões deste ensaio. Observa-se que os pontos de ruptura encontram-se próximos um do outro no gráfico t e s'. As curvas apresentam comportamentos semelhante, porém a cada estágio, as trajetórias deslocam-se para a direita do gráfico, como já observado previamente em outros ensaios. Ou seja, há 
menor geração de pressões neutras ao longo de um ensaio multi-estágio. Provavelmente, neste teste, esta diminuição de geração de pressões neutras se deve à saída de água após a abertura das drenagens, realizado após o descarregamento axial. A diminuição de geração de poro-pressões também foi observada por Parry e Nadajarah (1973) e Nambiar et al (1985), como já discutido previamente.

Porém, neste solo, estas diferenças não representam mudanças significativas na estimativa dos pontos de ruptura, já que a variação das pressões neutras tende a se igualar com o aumento da deformação.

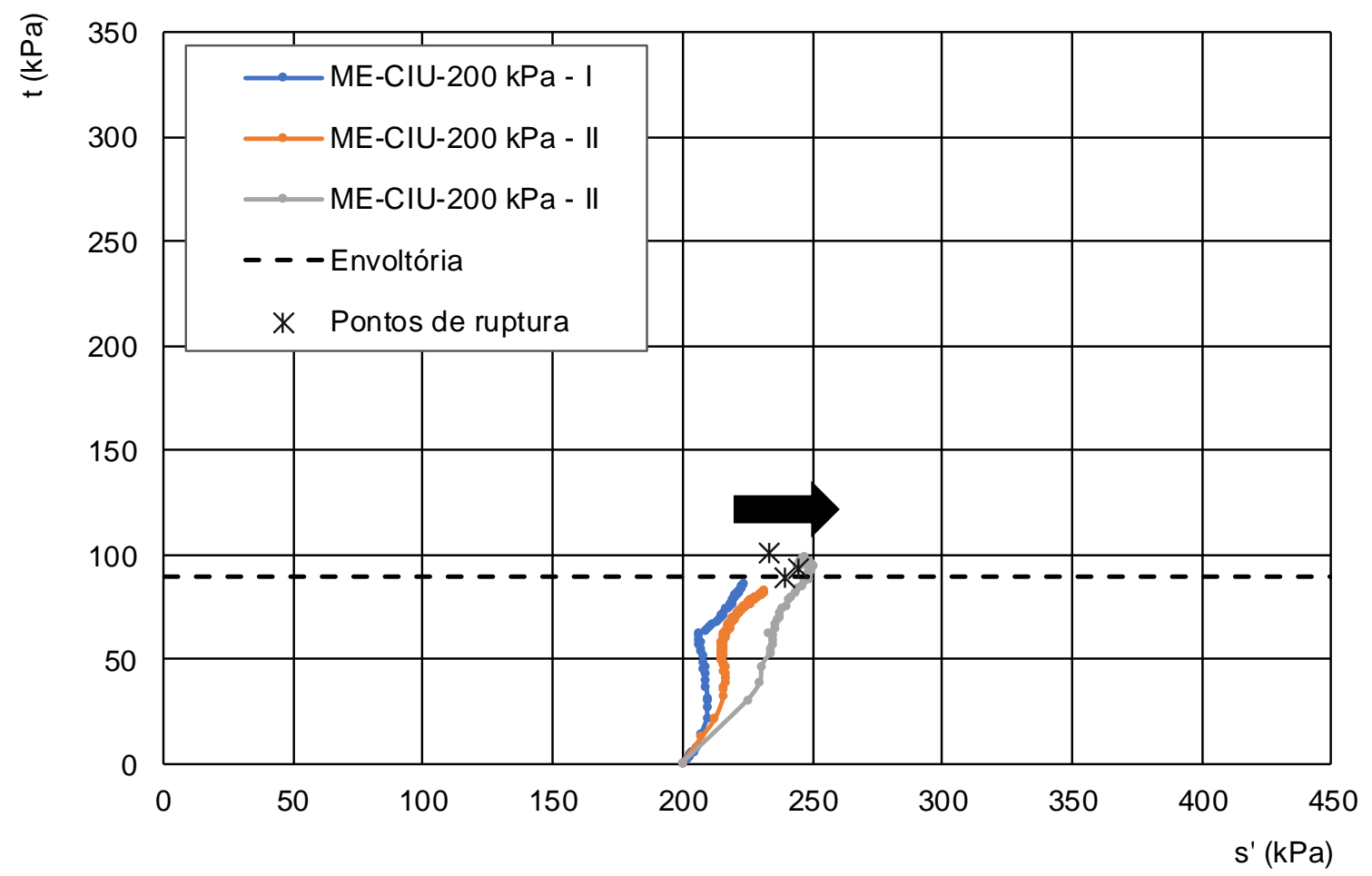

Figura 111. Trajetórias de tensão do ensaio $C$, indicando deslocamento das trajetórias de tensão para a direita ao longo do ensaio

Dessa forma, pode-se afirmar que ocorrem mudanças na estrutura deste solo ao longo do ensaio multi-estágio, porém, estas não são suficientes para alterar a definição dos pontos de ruptura, e portanto, a técnica multi-estágio é apta para estimar os parâmetros de ruptura de forma eficaz.

Em relação aos módulos de deformabilidade, como discutido no item 6.3.1, no início das etapas intermediárias de cisalhamento há modificação da rigidez do corpo de prova, até a porcentagem de deformação ao qual a amostra já foi submetida. Os módulos de deformabilidade obtidos no ensaio C estão apresentados na Figura 112, 
onde observa-se que ocorre variação dos módulos no a partir do segundo estágio. Porém, o comportamento dos módulos é o mesmo no segundo e terceiro estágio.
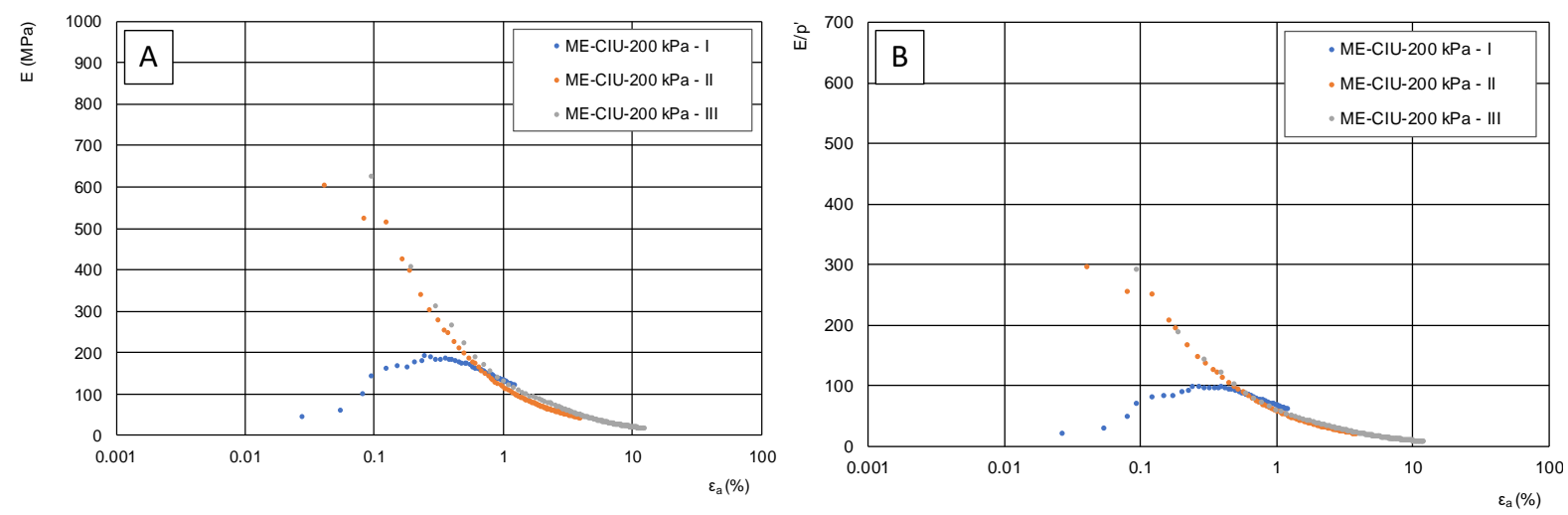

Figura 112. (A) módulos de deformabilidade secantes obtidos no ensaio C. (B) módulos de deformabilidade secantes normalizados por $\mathbf{p}^{\prime}$

Nos ensaios A e B, realizados em amostras compactadas, observou-se maiores variações nas tensões de ruptura e nos módulos de deformabilidade do que nas amostras indeformadas. É provável que a cimentação e a imbricação natural dos grãos sejam responsáveis pela manutenção da resistência e dos módulos de deformabilidade nas amostras indeformadas. É provável que a cimentação, por apresentar comportamento mais rígido, impeça a densificação nos estágios de cisalhamento.

Como discutido no item 2.4.2.4, Parry e Nadajarah (1973) analisaram a variação de índice de vazios e volume de uma amostra indeformada e de uma amostra compactada ao longo de ensaios multi-estágios e concluíram que há maior variação de volume na amostra compactada. Dessa forma, é possível concluir que há maior densificação, e modificação da estrutura, nas amostras compactadas do que nas amostras indeformadas.

No item 6.1 concluímos que a densificação das amostras compactadas não modifica os parâmetros de resistência do solo, porém, afeta consideravelmente os módulos de deformabilidade. Dessa forma, para os solos compactados e pouco cimentados, recomenda-se a aplicação do ensaio multi-estágio apenas para a definição dos parâmetros de resistência.

Para as amostras indeformadas analisadas, os estágios iniciais de cisalhamento não afetam a estimativa dos parâmetros de resistência. Porém, os módulos de deformabilidade são afetados pelos estágios iniciais. 
Recomenda-se atentar-se aos níveis de tensões de ensaio em amostras indeformadas. A partir da tensão de cedência, onde as ligações por cimentações são quebradas durante o adensamento ou cisalhamento, é provável que os ensaios multiestágios não apresentem a mesma eficiência.

\subsubsection{Variação de volume e índice de vazios ao longo de ensaios multi-estágios}

Foi realizada a comparação da variação da variação de índice de vazios ao longo do ensaio multi-estágio $G$ e o ensaio convencional $D$. Não foi possível realizar esta análise nas outras amostras, pois os demais ensaios foram feitos utilizando um software que não grava os dados necessários para tal.

A Figura 113 apresenta a variação do índice de vazios ao longo dos ensaios G e D, realizados. No primeiro estágio, a variação de índice de vazios é exatamente a mesma para os dois estágios. Nos estágios seguintes, observa-se maior variação de índice de vazios no ensaio convencional. Esperava-se maior variação no ensaio multiestágio. Porém, a diferença da variação entre os dois ensaios é tão pequena (menor que $e=0.05$ ), que pode ser desconsiderada. Dessa forma, pode-se concluir que os estágios de cisalhamento iniciais do ensaio multi-estágio não geram compressão e densificação significativa nos corpos de provas indeformados do solo analisado.

Como discutido no item 6.1 e afirmado pelo estudo de Parry e Nadajarah (1973), o mesmo não ocorre nas amostras compactadas. Vê-se que a cimentação e o imbricamento natural dos grãos apresentam uma ação relevante neste caso. 

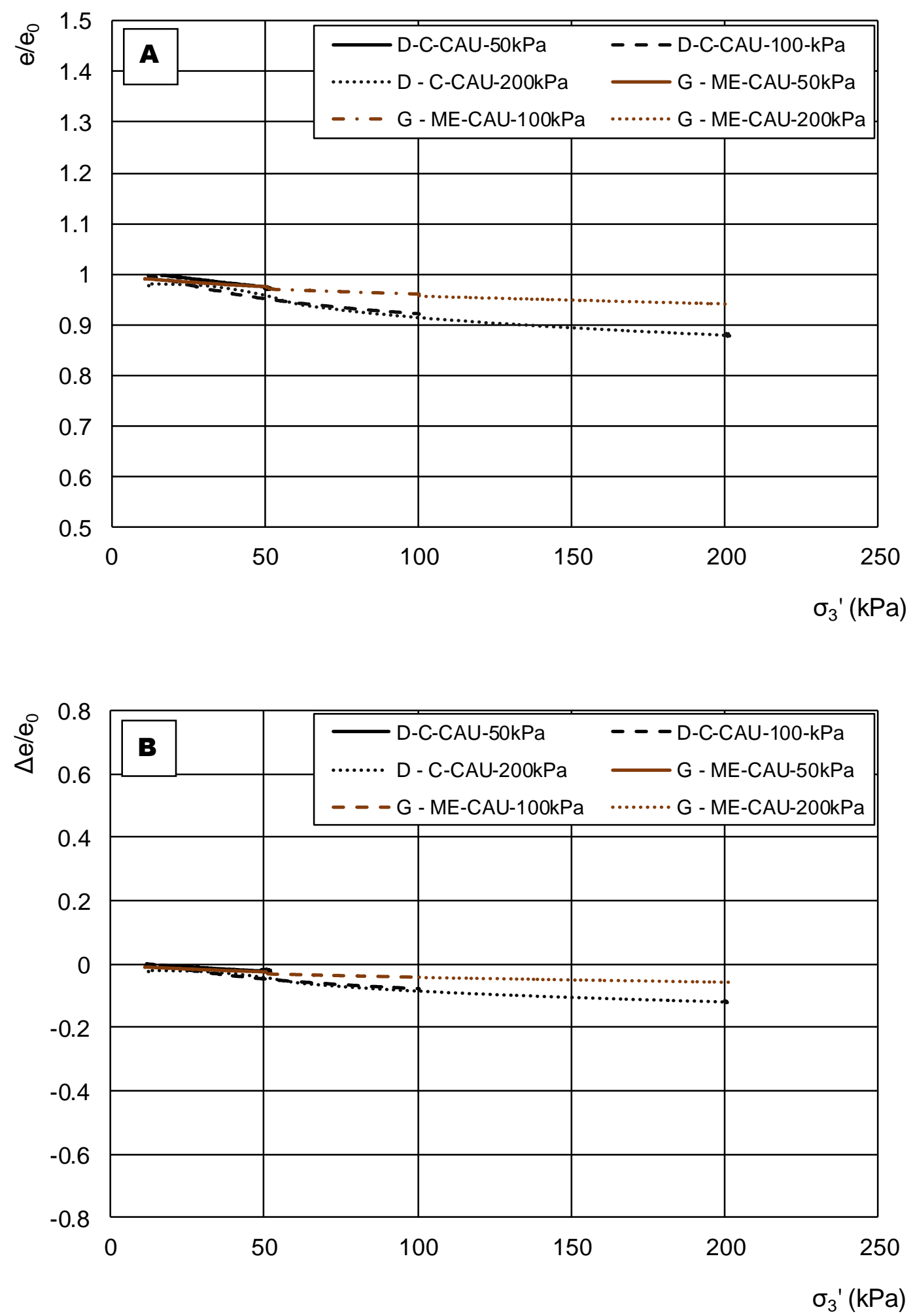

Figura 113. Variação do índice de vazios durante os estágios de adensamento dos ensaios $D$ e G. (A) gráfico entre razão do índice de vazios ao longo do adensamento e o índice de vazioinicial versus aumento da tensão confinante. (B) gráfico da variação do índice de vazios versus aumento da tensão confinante 


\subsection{Análise microestrutural de corpos de provas submetidos à compressão triaxial}

As amostras utilizadas nos ensaios de $50 \mathrm{kPa}$ e $100 \mathrm{kPa}$ do ensaio convencional $\mathrm{De}$ a amostra utilizada no ensaio multi-estágio $G$ foram analisadas em microscópio eletrônico de varredura, a fim de estudar a microestrutura das zonas de cisalhamento geradas durante os ensaios.

Foram realizadas imagens seguindo os planos de ruptura identificados nestas amostras. Os foto-mosaicos que ilustram estes planos de ruptura estão apresentados no Anexo A, com indicação de escala e de topo e base. Na amostra do ensaio $G$ também foi feito um foto-mosaico no centro do corpo de prova, fora da zona de cisalhamento.

As descrições das zonas de cisalhamento estão apresentadas nos itens a seguir.

\subsubsection{Ensaio D - C-CAU-50 kPa}

Como ilustrado na Figura 47, o ensaio de $50 \mathrm{kPa}$ do ensaio $\mathrm{D}$ foi continuado até $6,63 \%$ de deformação. Parte do plano de ruptura (ou plano de falha) está apresentado na Figura 114.

O plano de ruptura é delimitado por paredes (contatos) irregulares e rugosas e apresenta espessura que varia entre $1 \mathrm{~mm}$ e $1,5 \mathrm{~mm}$. É preenchido por grumos e aglomerados de minerais que, em sua maioria, apresentam formato esférico ou alongado. De modo geral, os aglomerados minerais alongados apresentam extremidades ovaladas e situam-se paralelos ao plano de falha.

Entremeados a estes aglomerados, há presença de poros de dimensões variadas. Os poros de maior extensão apresentam até $4 \mathrm{~mm}$ de comprimento, possuem formato alongado e apresentam-se paralelos às paredes do plano de falha. Na imagem, os poros são identificados por apresentarem coloração preta e homogênea. Esta coloração é a resposta típica da resina epoxy. 


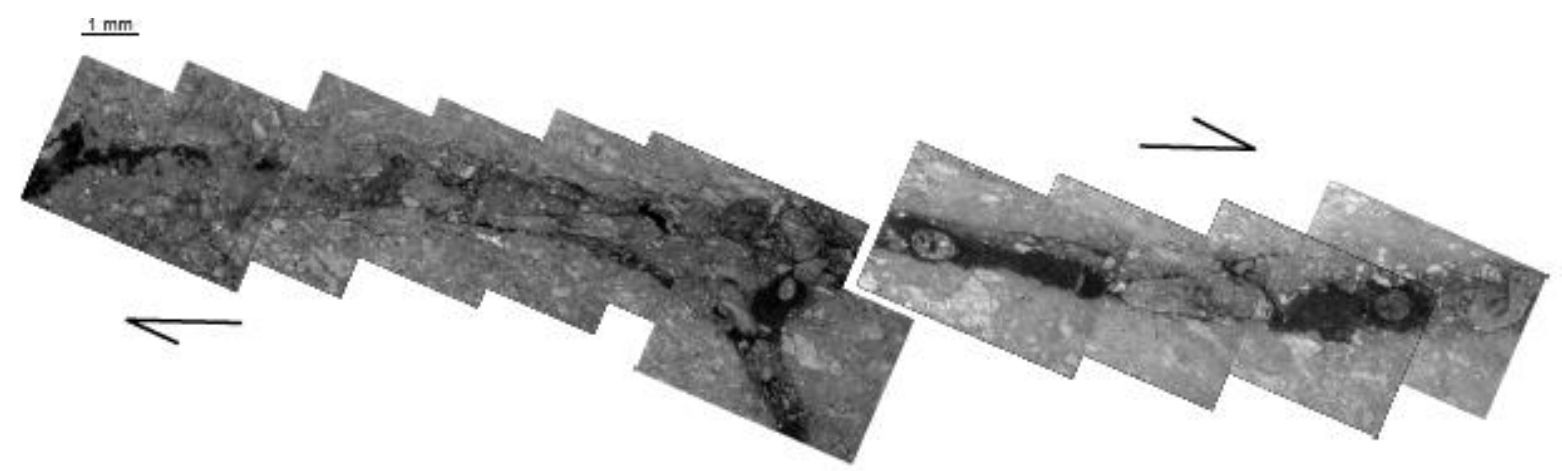

Figura 114. Trecho do plano de ruptura obtido no ensaio D-C-CAU-50 kPa observado em MEV

As imagens na Figura 115 apresentam, em detalhe, um trecho do plano de falha, ilustrando a textura de seu preenchimento e do solo ao seu redor. A imagem $115.1 \mathrm{e}$ 115.2 apresentam a textura de um grumo de minerais e do preenchimento do plano de falha ao redor deste grumo, respectivamente. Já a imagem 115.3 apresenta a textura do solo próximo às paredes.

Observa-se que o preenchimento e os grumos observados dentro do plano de falha apresentam textura semelhante, com menor granulometria e menor porosidade do que o solo ao seu entorno. Na Figura 115.3, é possível observar as placas de argila e os poros entre elas.

A partir destas imagens, interpretou-se que, possivelmente, no início do carregamento axial, ocorre separação dos agregados minerais localizados na zona de falha, diminuindo o índice de vazios e gerando a textura observada nas Figuras 115.1 e 115.2, como sugerido por Skempton (1985) na Figura 4. Com o aumento da deformação e o deslocamento das paredes da falha, este preenchimento é movido. As zonas do preenchimento mais coesas são movidas em conjunto, formando os grumos observados. A formação destas zonas mais coesas pode ser explicada pela tendência de aproximação química de placas de argilas.

Provavelmente, com o aumento da deformação os grumos adquirem formato alongado, devido ao atrito com as paredes da zona de ruptura. Os grumos menores, possivelmente, são rotacionados durante o cisalhamento e, por isso, apresentam formato esférico, como ilustrado na Figura 115. 

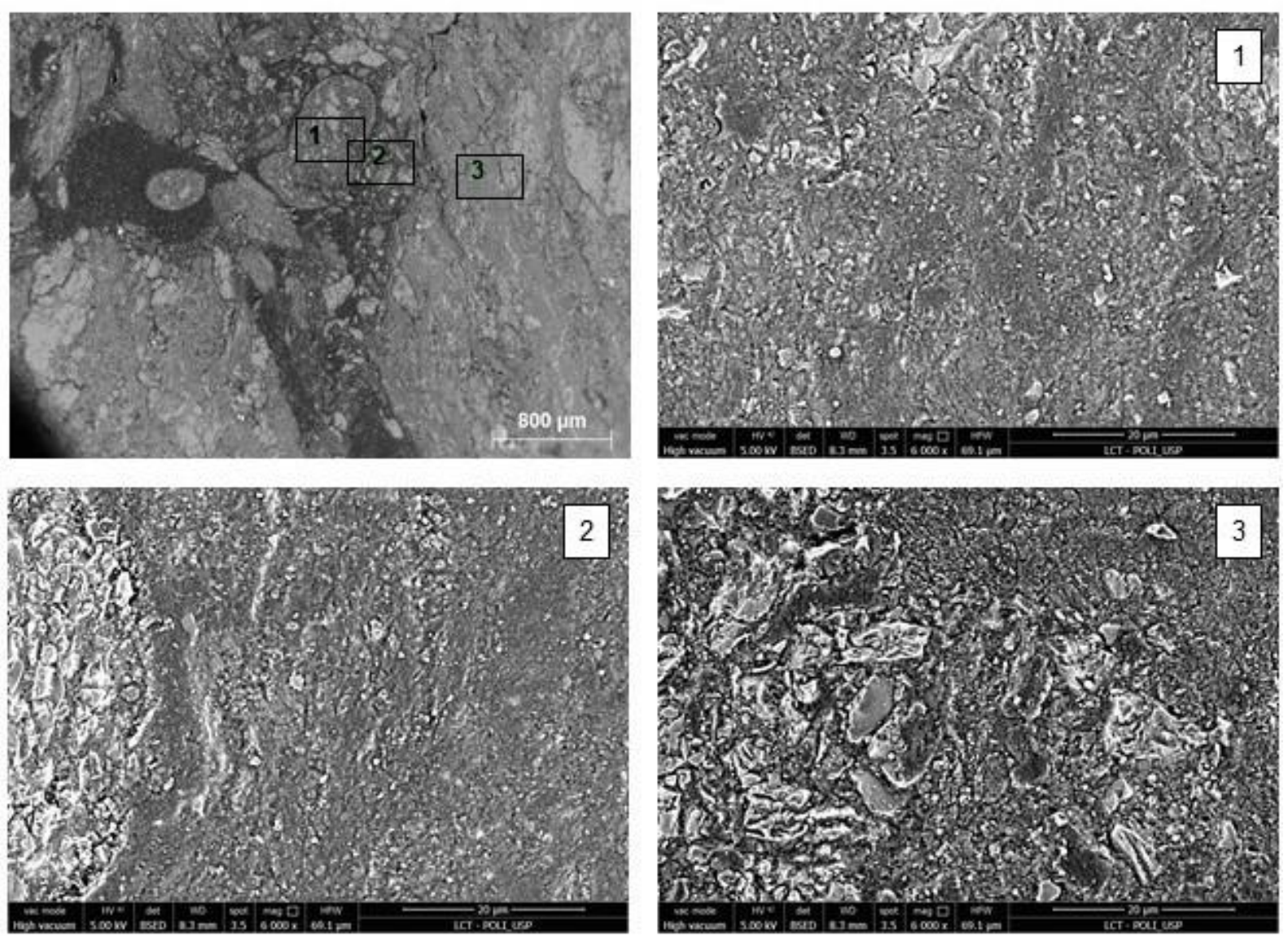

Figura 115. Detalhe do plano de ruptura obtido no ensaio D-C-CAU-50 kPa, ilustrando as paredes e o seu preenchimento, com indicação dos pontos observados com maior detalhe. (1) textura de um grumo de solo; (2) textura do preenchimento da falha, ao lado do grumo; (3) textura do solo próximo à parede do plano de ruptura

Também observou-se alinhamento dos grãos próximos às paredes dos grãos, como ilustrado na Figura 116. Estes alinhamentos também foram observados por Tchalenko (1967), que as denominou de Kink Bands. Estes lineamentos são correlacionáveis com as estruturas s-c, típica de rochas miloníticas. 


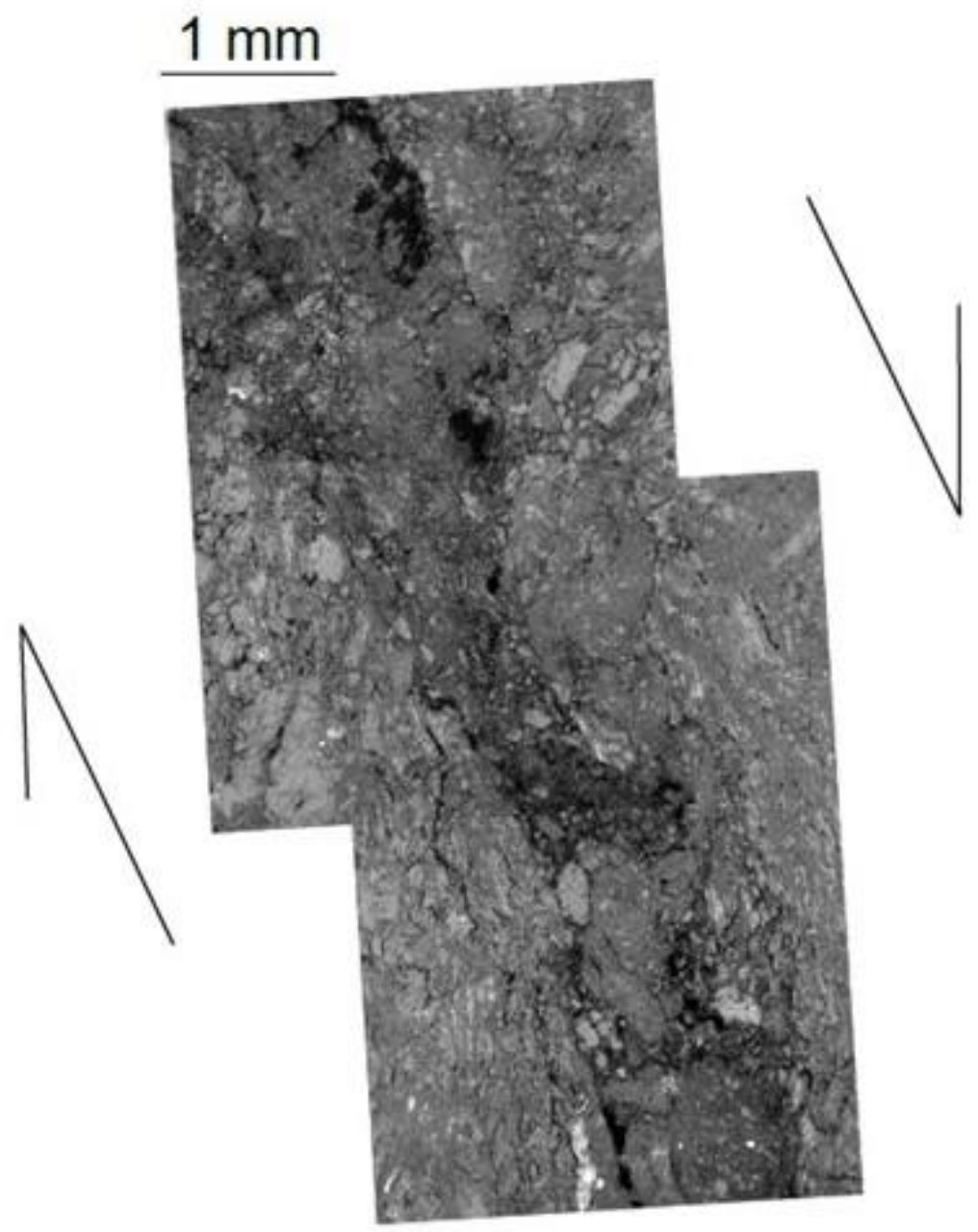

Figura 116. Trecho do plano de ruptura obtido no ensaio D-C-CAU-50 kPa, com lineações próximas às paredes de falha evidentes (kink bands)

No foto-mosaico, presente no Anexo A, onde o trecho do plano de ruptura analisado é ilustrado em toda a sua totalidade, observa-se que o plano se divide, formando um plano menor que intercepta obliquamente o plano principal.

\subsubsection{Ensaio D - C-CAU-100 kPa}

A Figura 117 apresenta um trecho da zona de cisalhamento observada no corpo de prova utilizado no ensaio triaxial convencional $\mathrm{A}$, realizado com $100 \mathrm{kPa}$ de tensão confinante. Este ensaio foi continuado até a deformação de 9,49\%. O Anexo A apresenta o todo o trecho do plano analisado, com indicação de topo e base. 


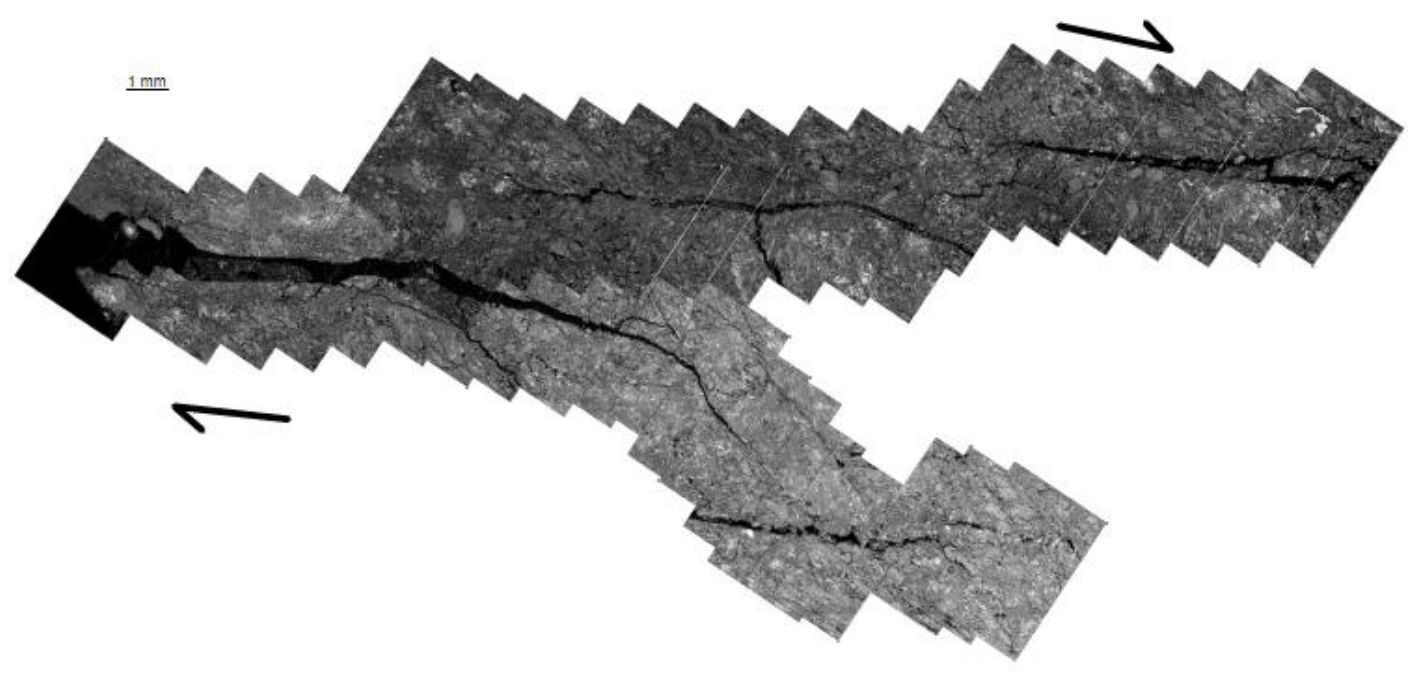

Figura 117. Trecho do plano de ruptura obtido no ensaio D-C-CAU-100 kPa observado em MEV

Esta zona de cisalhamento é formada por dois planos de fraturas principais (PSZ) subparalelos. Há formação de curvas oblíquas aos planos principais. A geometria desta zona assemelha-se ao esquema de Riedel, apresentado no item 2.2. É possível observar as zonas conjugadas $\mathrm{R}$ e $\mathrm{R}$ '. $\mathrm{O}$ ângulo entre a zona $\mathrm{R}$ e o plano de cisalhamento principal é de $12^{\circ}$. Este valor é compatível com o ângulo de atrito obtido no ensaio. Previa-se que o ângulo entre R e PSZ seria de $10^{\circ}$ (metade do ângulo de atrito estimado). Também foi possível identificar indicadores cinemáticos que indicam o caráter antitético de R'. O deslocamento principal ocorre no sentido horário e na zona R' ocorre no sentido anti-horário, como indicado no detalhe da Figura 118.

Nota-se que os planos de cisalhamento principais não são contínuos, o que confirma a teoria de que o surgimento do plano principal é posterior ao acionamento das zonas $R$ e R'. 


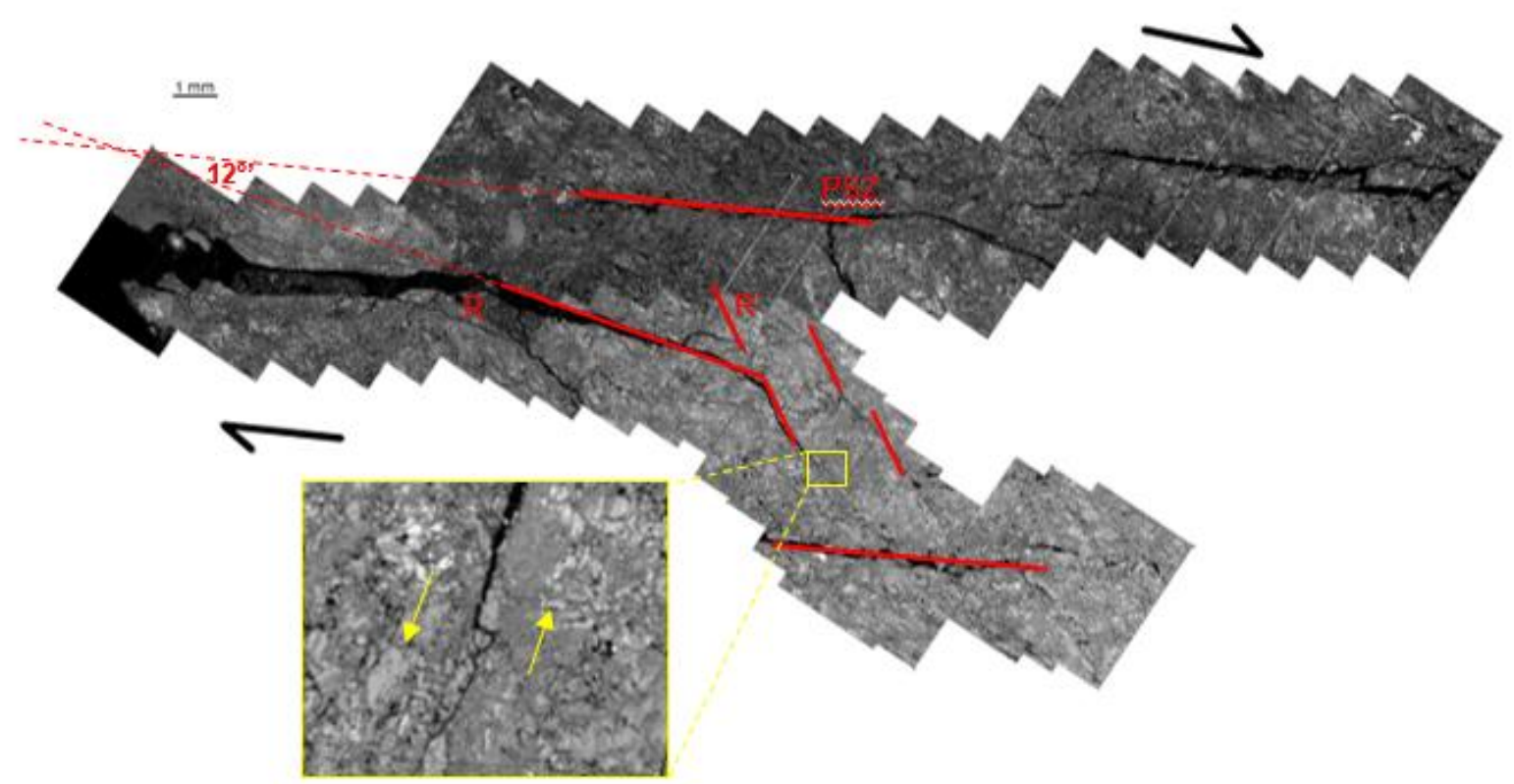

Figura 118. Zona de cisalhamento do ensaio D-C-CAU-100 kPa, com indicações do esquema de Riedel, com indicador cinemático provando caráter antitético de $\mathbf{R}^{\prime}$

A zona de cisalhamento apresenta espessura de cerca de $1,1 \mathrm{~cm}$ e os planos de cisalhamento principais apresentam espessuras entre 0,5 e $0,8 \mathrm{~mm}$.

Diferente da zona de cisalhamento do ensaio de $50 \mathrm{kPa}$, as paredes das zonas principais apresentam-se retificadas, indicando bom desenvolvimento do deslocamento. Outra diferença está no preenchimento. No ensaio de $100 \mathrm{kPa}$ os planos principais apresentam elevada porosidade, e grande parte dos planos não está apresenta preenchimento. Porém, em alguns locais, observa-se grumos alongados, como o que está indicado na Figura 119.

A Figura 119.B apresenta o contato entre a grumo que preenche o plano principal e o solo ao seu entorno. Nota-se que o grumo apresenta grãos com menor granulação e menor porosidade. 

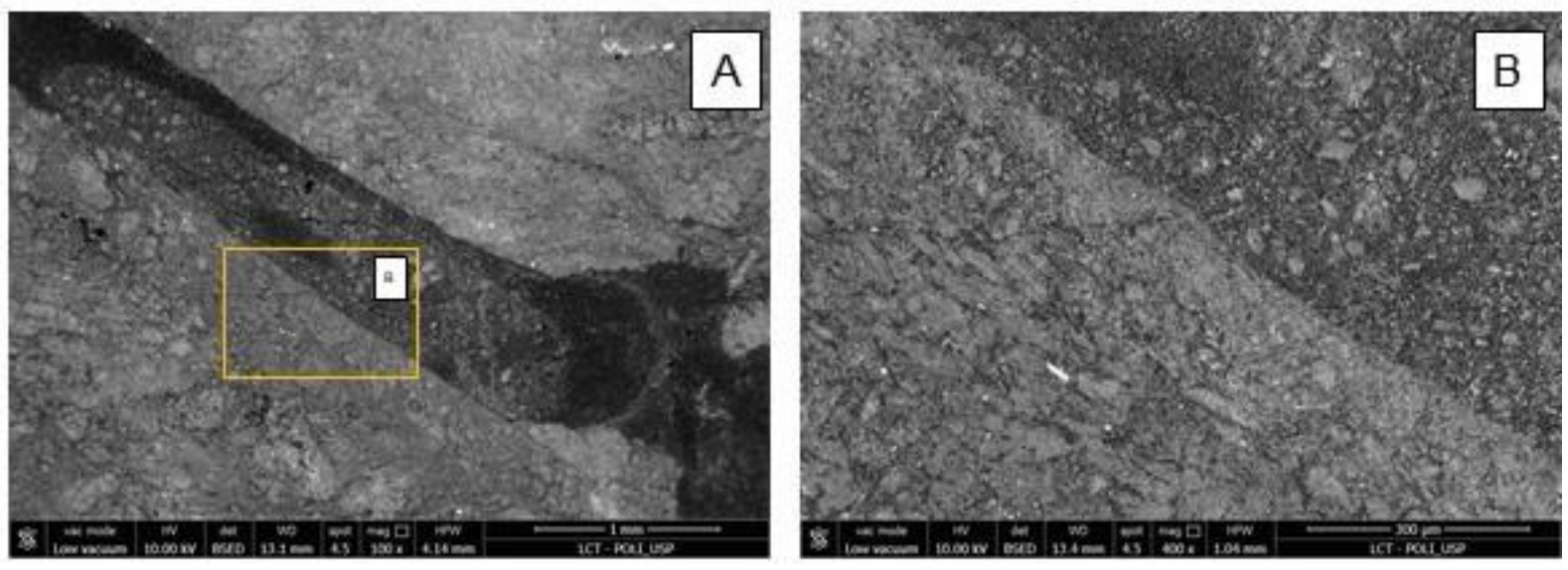

Figura 119. Zona de cisalhamento do ensaio D-C-CAU-100 kPa. (A) detalhe do PSZ com preenchimento; (B) imagem de maior detalhe diferenciando a textura interna e externa do PSZ

Nota-se que as estruturas geradas nos ensaios de 50 kPa e 100 kPa são distintas. No ensaio de $50 \mathrm{kPa}$ observou-se um único plano de ruptura, com maior preenchimento e lineações em torno de suas paredes rugosas. No ensaio de $100 \mathrm{kPa}$ observa-se uma zona de cisalhamento com falhas conjugadas, com maior presença de trincas e planos com paredes retificadas e com pouco preenchimento. Ou seja, nota-se um comportamento predominantemente rúptil neste último ensaio.

Estas diferenças podem ser causadas pela diferença da tensão de confinamento dos ensaios, pelas diferenças no grau de deformação atingido ou pela heterogeneidade da amostra. Acredita-se que a tensão de confinamento efetiva pode ser um fator preponderante na definição das microestruturas geradas em ensaios não drenados, uma vez que a ação das poro-pressões dentro do corpo de prova é de grande influência na formação das estruturas plásticas e rúpteis.

\subsubsection{Ensaio G - ME-CAU-50,100 kPa}

No ensaio multi-estágio $G$ foram realizadas dois estágios de cisalhamento, com tensões de adensamento de 50 e $100 \mathrm{kPa}$, e um estágio de adensamento até 200 $\mathrm{kPa}$. Em seguida, o corpo de prova foi retirado para realização das análises microestruturais. Ou seja, o corpo de prova analisado apresenta a microestrutura que possuiria no momento do início do último estágio do teste.

Apesar do ensaio ter sido paralisado no pico da tensão desviadora, no limiar da ruptura, observa-se formação de um plano de ruptura, com desenvolvimento de estruturas de cisalhamento. 
Foram realizadas análises em dois locais do corpo de prova, foi realizada uma sessão vertical no centro do corpo de prova e um foto-mosaico seguindo a zona de cisalhamento. Estas duas sessões estão apresentadas no Anexo A e um trecho da zona de cisalhamento está ilustrada na Figura 120.

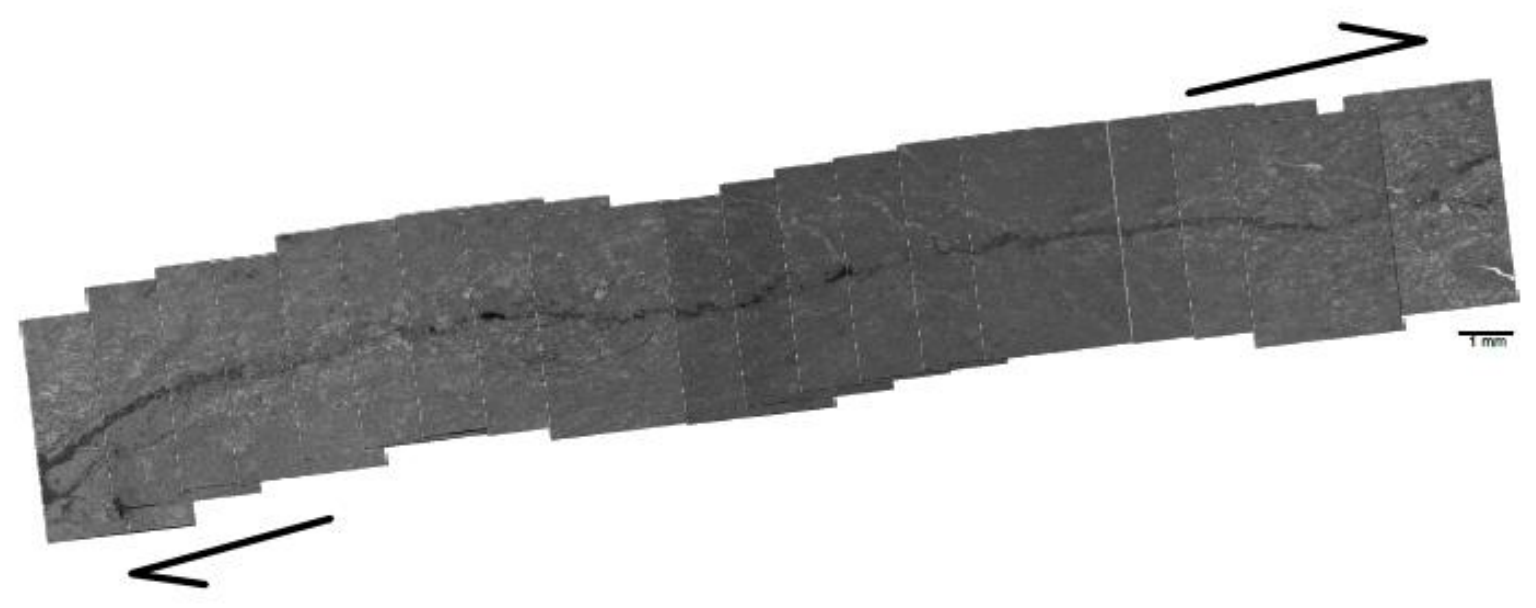

Figura 120. Trecho do plano de ruptura obtido no ensaio D-C-CAU-100 kPa observado em MEV

Observa-se formação de dois planos de rupturas na zona de cisalhamento. No topo da zona de cisalhamento há formação de um plano oblíquo ao plano principal, que intercepta os limites dos corpos de prova.

O plano de ruptura principal apresenta espessuras entre 0,1 e $03 \mathrm{~mm}$ e apresenta paredes rugosas, mostrando que não houve deslocamento efetivo entre as paredes. Em alguns locais o plano principal é descontinuado.

Em relação ao preenchimento do plano, boa parte do plano é preenchido por aglomerados minerais entremeados por poros paralelos às paredes do plano de ruptura. Em alguns locais, observa-se fissuras entre as paredes.

Em torno do plano de ruptura principal, observam-se lineações oblíquas, correlacionáveis com as Kink Bands de por Tchalenko (1967). E podem ser consideradas as zonas sintéticas $\mathrm{R}$ do esquema de Riedel.

As imagens da Figura 121 apresenta as principais estruturas descritas acima, com detalhes dos aglomerados minerais que preenchem o plano, as fissuras e as kink bands ao redor do plano. A Figura 122 apresenta, em detalhe, a rugosidade das paredes do plano de ruptura. 

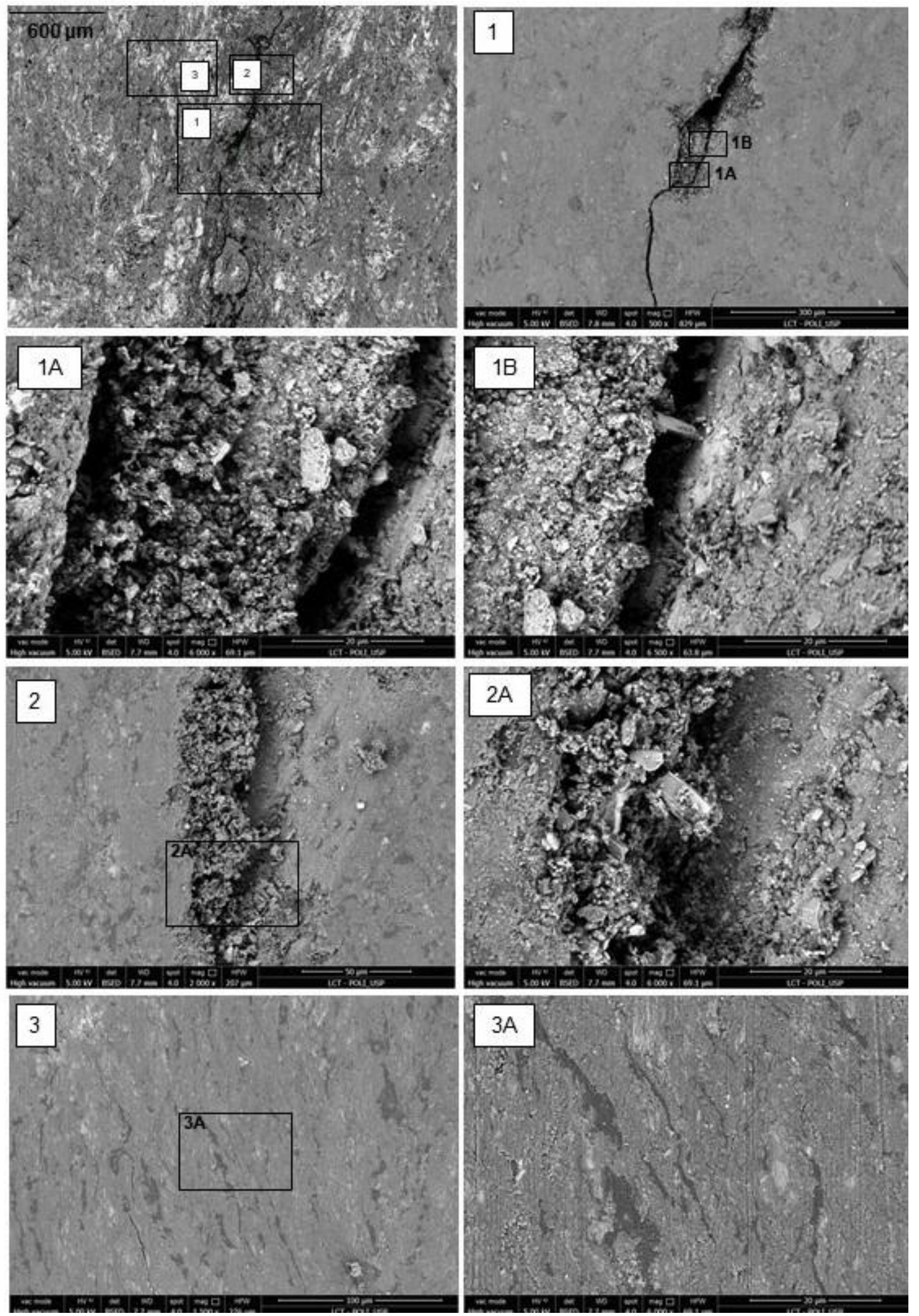

Figura 121. Microestruturas observadas na zona de cisalhamento gerada no ensaio G-MECAU-50,100 kPa. Em 1, 1A e 1B observa-se aglomerado mineral que preenche o plano de ruptura: em 2 e 2A há um detalhe do preenchimento do plano; e em 3 e $3 A$ observa-se lineações geradas próximas ao plano de falha. 

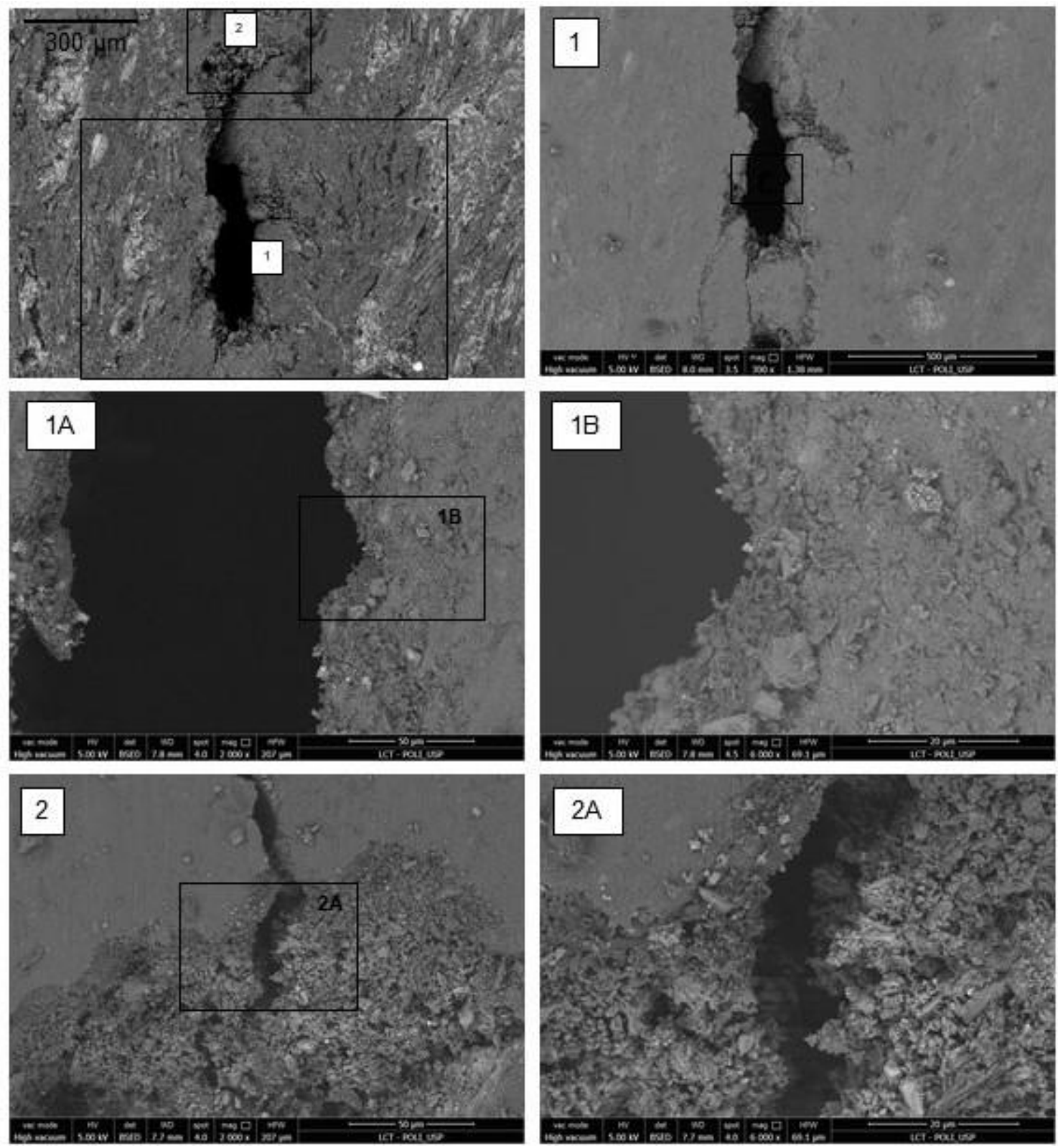

Figura 122. Detalhe das paredes do plano de ruptura gerada no ensaio G-ME-CAU-50,100 kPa

Não foi observado zonas antitéticas R'. A movimentação da zona de cisalhamento só ocorre quando há ativação das zonas $R$, R' e P. Não foram encontradas evidências do desenvolvimento das zonas $R^{\prime}$ e $P$, comprovando novamente que não houve movimentação das paredes. A baixa espessura do plano, a ausência de indícios de movimentação do plano e a geração das zonas $\mathrm{R}$ sem a formação da zona conjugada $R^{\prime}$ indicam que a zona de cisalhamento observada ainda apresenta-se pouco desenvolvida. 


\subsection{Influência da Heterogeneidade do Solo na Estimativa dos Parâmetros de Ruptura em Ensaios Convencionais}

O solo analisado apresenta elevada heterogeneidade. As elevadas diferenças composicionais, herdadas da rocha mãe, afetam a mineralogia, granulometria, estrutura e os parâmetros de resistência e deformabilidade do solo. Esta heterogeneidade cria uma dificuldade na avaliação dos ensaios multi-estágios das amostras indeformadas, desta forma, será discutido neste item as variações naturais do comportamento tensão-deformação e dos parâmetros de resistência deste solo. As análises foram realizadas a partir dos resultados dos ensaios $D$ e $E$ e de dados obtidos na literatura.

Foram realizados dois ensaios triaxiais convencionais e os parâmetros de resistência obtidos apresentaram divergências substanciais, com diferenças de $32 \mathrm{kPa}$ na coesão e de $15^{\circ}$ no ângulo de atrito, além de apresentarem comportamentos de tensãodeformação distintos.

$O$ ensaio $D$ foi realizado com amostras do bloco $A$ e o ensaio $E$ foi realizado utilizando amostras do bloco $\mathrm{C}$. Apesar das amostras serem retiradas de blocos distintos, os blocos foram retirados de locais próximos, com menos de $50 \mathrm{~cm}$ de distância, como ilustrado na Figura 25.

A Figura 123 apresenta o comportamento tensão-deformação dos ensaios D e E. Os ensaios realizados com tensão de adensamento de $100 \mathrm{kPa}$ apresentaram boa correlação nos valores de tensão de ruptura, apesar de apresentarem comportamento diferentes. Há formação de pico de tensão bem mais evidenciado no ensaio E. Nos demais estágios as tensões desviadoras atingidas no ensaio $E$ foram muito elevadas, quando comparada com o ensaio D. 

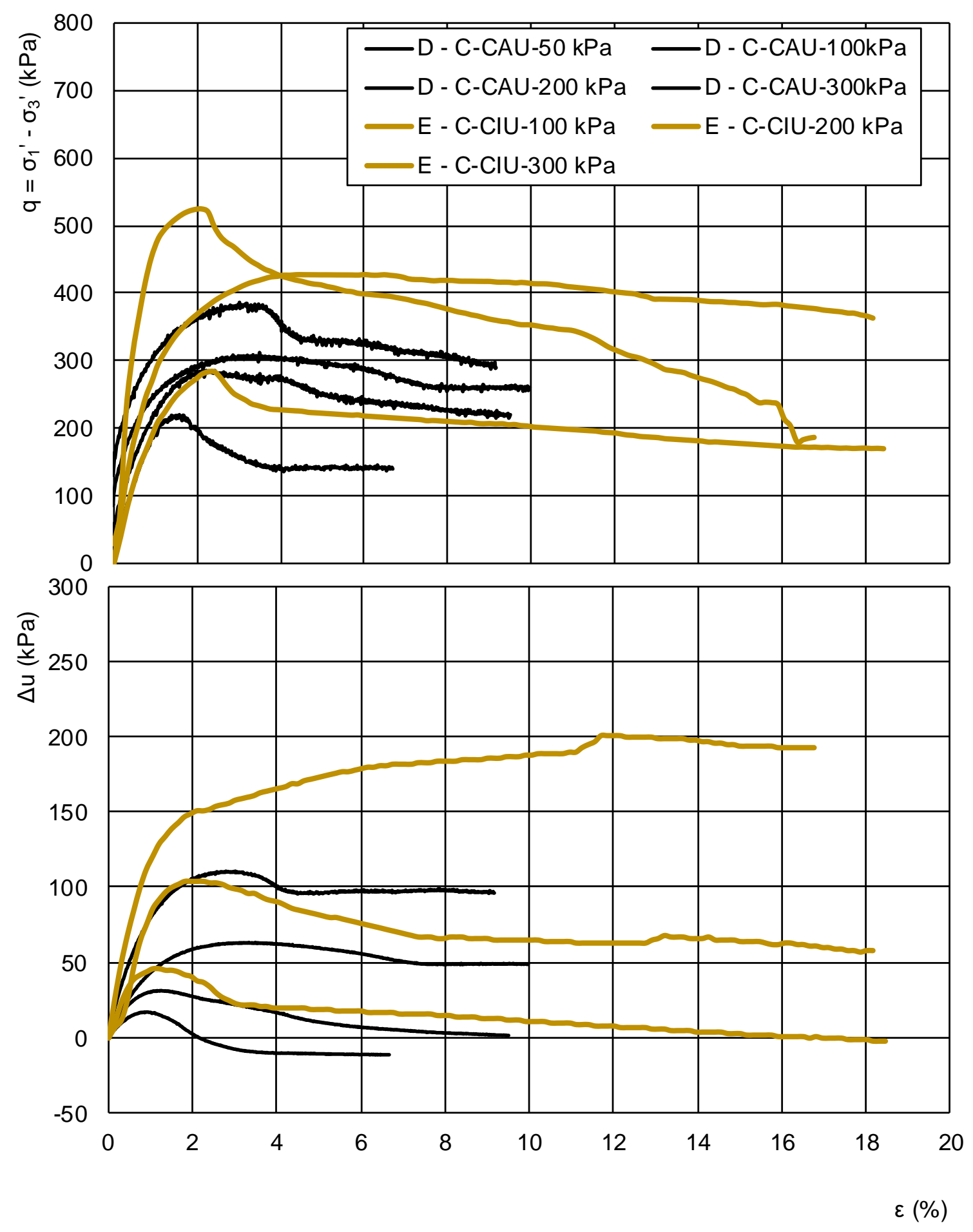

Figura 123. Comportamento tensão-deformação obtidos nos ensaios D e E 


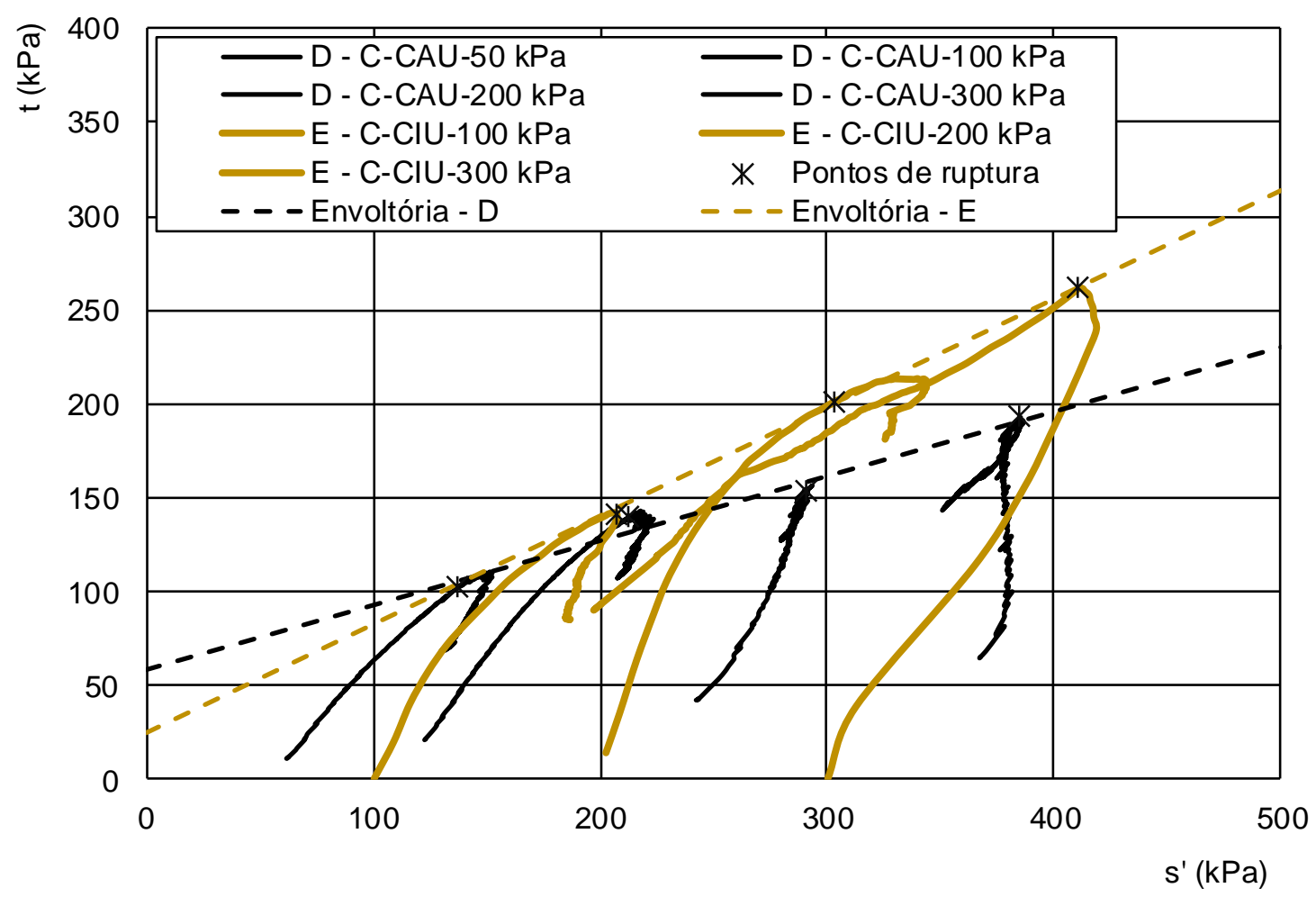

Figura 124. Trajetórias de tensões obtidas nos ensaios D e E

A Figura 124 apresenta as trajetórias de tensões nos ensaios convencionais realizados, ilustrando as diferenças entre os pontos de ruptura e nas envoltórias de tensões.

A Tabela 20 a seguir apresenta os valores dos parâmetros de resistência efetivos deste solo encontrados na literatura. Há diferenças de até $107 \mathrm{kPa}$ de coesão e $15^{\circ}$ de ângulo de atrito.

Tabela 20. Parâmetros de resistência efetivos do solo

\begin{tabular}{lcccc}
\hline & Tipo de ensaio & Tipo de amostra & $\mathbf{c}^{\prime}(\mathbf{k P a})$ & $\boldsymbol{\varphi}^{\prime}\left(^{\circ}\right)$ \\
\hline \multirow{2}{*}{ Vieira (1999) } & CAU & Indeformada & 8.7 & 23 \\
& CAU & Indeformada & 16 & 32 \\
\hline ABEF (1989) & CU & Indeformada & 116.28 & 28 \\
\hline \multirow{2}{*}{ Estudo atual } & CAU & Indeformada & 60 & 20 \\
& CIU & Indeformada & 29 & 35 \\
\hline
\end{tabular}

Estas divergências de valores dificulta a definição dos parâmetros de projeto e a correta caracterização do solo, sendo necessários mapeamentos de detalhe. Outra preocupação ao lidar com solos extremamente heterogêneos é a necessidade de integrar dados advindos de amostras diferentes, como é o caso dos ensaios triaxiais convencionais, onde a envoltória de ruptura é definida a partir de três amostras distintas. 
Esta dificuldade ocorreu durante o desenvolvimento da presente pesquisa. O ensaio D inicialmente seria realizado com as tensões de adensamento de 50, 100 e $200 \mathrm{kPa}$, porém, devido à dificuldade de interpretação da correta envoltória de ruptura foi necessária a execução de um ensaio com tensão de 300 kPa. A Figura 125 apresenta duas possibilidades de interpretação da envoltória de ruptura, neste caso. Vale dizer, que os parâmetros de resistência obtidos em ambas as interpretações estão de acordo com dados encontrados na literatura.
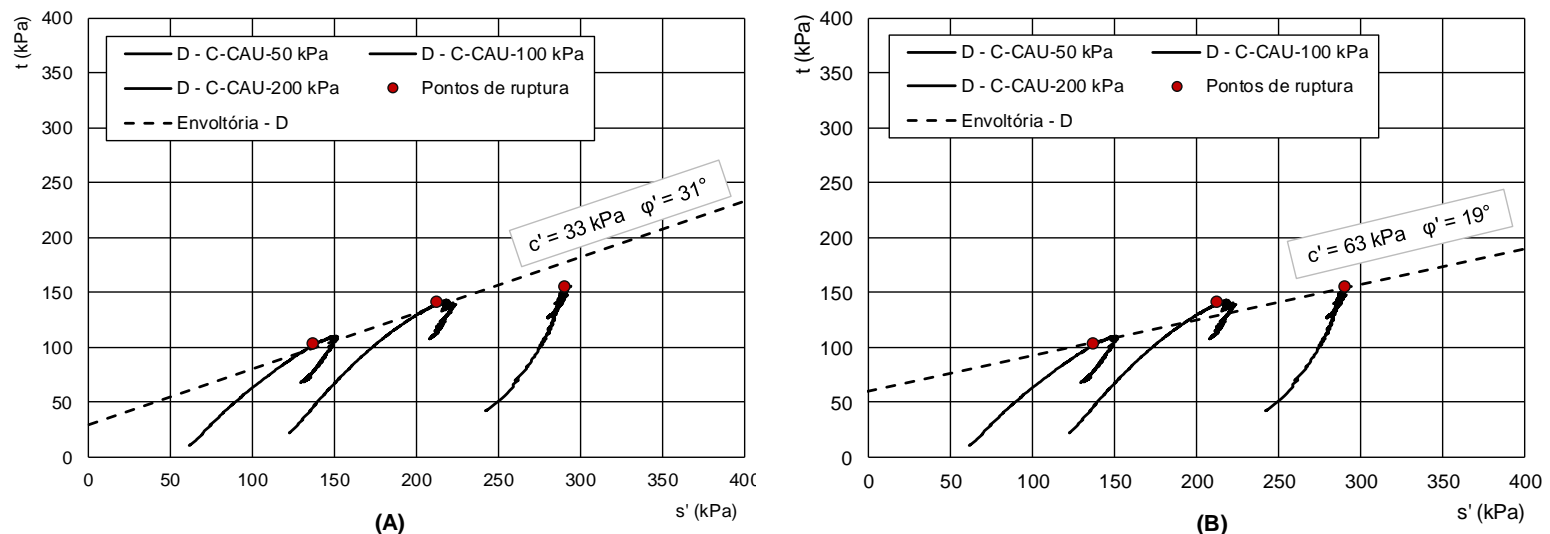

Figura 125. Dificuldades de interpretação de ensaios convencionais devido a elevada heterogeneidade do solo apresentadas no ensaio D

Para a definição dos valores de coesão adotadas neste estudo realizou-se um ensaio com tensão de confinante de $300 \mathrm{kPa}$ e concluiu-se que a amostra utilizada no ensaio de $100 \mathrm{kPa}$ apresenta composição mais resistente que as demais, e por isso, o seu ponto de ruptura localiza-se acima da envoltória de ruptura.

Esta amostra apresenta a mesma resistência da amostra utilizada no ensaio de 100 $\mathrm{kPa}$ do ensaio E. Possivelmente trata-se de uma zona mais resistente presente no bloco A que se repete, em maior quantidade, no bloco C. Dessa forma conclui-se que a dificuldade de interpolação de dados é advinda da heterogeneidade do solo. Assim, a hipótese de que uma envoltória curva seria mais adequada neste caso não é válida, pois a dificuldade de interpolação é resultante das diferenças composicionais do solo e não de seu estado de tensões. Estas diferenças afetariam também a interpretação de uma envoltória curva, que também não retrataria a resistência real do maciço.

ABEF (1989) retratou a mesma dificuldade ao estudar este solo. A Figura 126 apresenta alguns dos círculos de Mohr obtidos neste estudo, ilustrando a dificuldade de definição de envoltória de ruptura. Os autores não apresentaram a envoltória e os parâmetros de resistência interpretados neste estudo. 

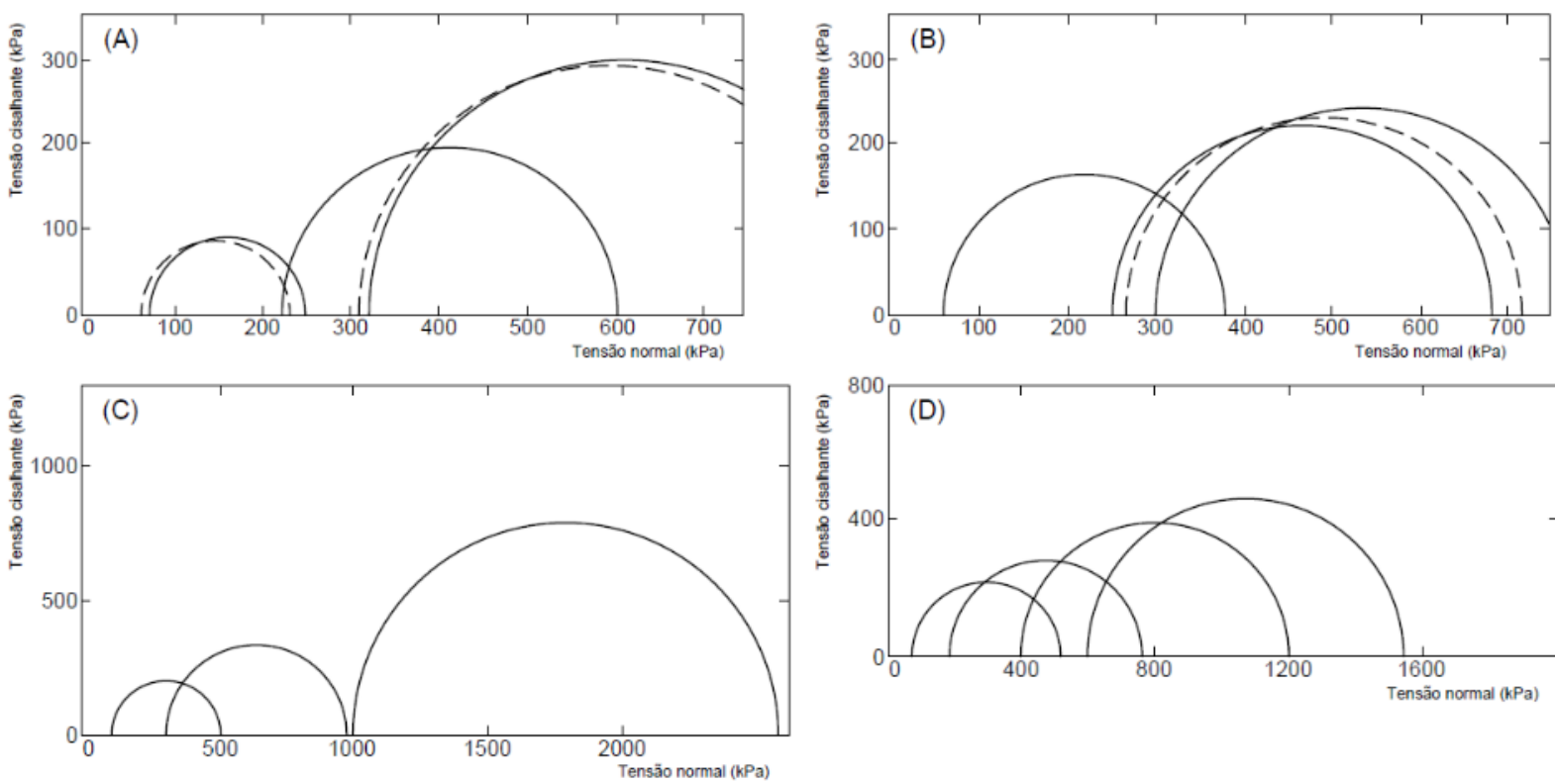

Figura 126. Círculos de Mohr de ruptura obtidos por ABEF (1989). Em (A) e (B) resultados de ensaios UU; Em (C) resultados de um ensaio CD: e em (D) resultados de um ensaio CU (adaptado de ABEF, 1989) 


\section{CONCLUSÕES}

Foram realizados ensaios triaxiais multi-estágios e convencionais em amostras indeformadas e amostras compactadas. Também foram obtidas imagens de MEV dos planos de ruptura em diferentes condições de deformação. A partir dos resultados foi possível analisar o efeito da técnica multi-estágio no comportamento tensãodeformação, na geração de poro-pressões e na definição dos parâmetros de resistência e deformabilidade nestes dois tipos de amostras. Além de descrever e avaliar alguns dos processos de desenvolvimento dos planos de ruptura em alguns corpos de prova.

Na etapa de caracterização do solo analisado e na análise dos dados da literatura, pode-se concluir que:

- O solo em estudo apresenta elevada heterogeneidade, com preservação das estruturas da rocha-mãe.

- Nos ensaios de caracterização, o solo foi classificado como um silte arenoso de alta plasticidade. Porém, a partir das análises da literatura observa-se que há trechos do solo formado por silte argiloso e argilas argilosas. Demonstrando, que o solo apresenta elevada variação granulométrica.

A partir da comparação dos ensaios triaxiais multi-estágios e convencionais realizadas em amostras compactadas, observou-se que:

- As alterações na estrutura da amostra em ensaios multi-estágios em corpos de prova compactados modificaram as tensões de ruptura nos estágios finais, superestimando as tensões desviadoras de ruptura.

- Os módulos de deformabilidade também foram afetados ao longo do ensaio.

A interpretação do ensaio C (ME-CIU-200,200,200 kPa), realizado com repetição da tensão de adensamento em uma amostra indeformada, mostrou que:

- As tensões de ruptura obtidas não apresentaram grandes variações, com diferenças de até $10 \%$.

- A cada estágio de cisalhamento, as trajetórias de tensões obtidas são gradualmente deslocadas para a direita, indicando que ocorre menor geração de poro-pressões no decorrer do ensaio. 
- Os pontos de ruptura localizam-se próximos no gráfico t versus s'. Ou seja, as fases de cisalhamento intermediárias não alteraram a resistência de amostras indeformadas de forma considerável.

A partir da realização de ensaios convencionais e multi-estágios em amostras indeformadas, conclui-se que:

- Os ensaios convencional $\mathrm{D}$ e o multi-estágio $\mathrm{G}$ e os ensaios convencional $\mathrm{E}$ e multi-estágio $\mathrm{H}$ apresentaram boa correlação no comportamento tensãodeformação e nos parâmetros de resistência obtidos.

- Nas trajetórias de tensões observou-se que há menor geração de poropressões em ensaios multi-estágios. As trajetórias de tensões obtidas em ensaios multi-estágios estão sempre posicionadas à direita das obtidas em ensaios convencionais.

- Na comparação entre o ensaio convencional D e o multi-estágio G não ocorreu variações significativas na variação do índice de vazios ao longo dos ensaios. Ou seja, as fases de cisalhamento não afetaram a compressibilidade da amostra nas fases de adensamento posteriores.

- A cimentação do solo é um fator preponderante na manutenção da estrutura ao longo dos estágios de cisalhamento sucessivos. Os estágios iniciais de cisalhamento devem ser realizados em níveis de tensões abaixo da tensão de cedência do solo, para garantir a eficácia do método multi-estágio.

- Em relação aos módulos de deformabilidade obtidos em ensaios multi-estágios nas amostras indeformadas, observou-se que estes não são correlacionáveis aos obtidos em ensaios convencionais no início das fases de cisalhamento finais. Os módulos obtidos em ensaios multi-estágios são correlacionáveis apenas após atingir taxas de deformação não atingidas em estágios anteriores.

A partir das imagens de MEV foram realizadas análises microestruturais das zonas de cisalhamento em amostras submetidas a ensaios convencionais $(D)$ e ao ensaio multiestágio (G). Conclui-se que:

- A zona de cisalhamento formada no ensaio convencional D com $100 \mathrm{kPa}$ apresenta comportamento menos plástico do que a formada no ensaio de $D$ com $50 \mathrm{kPa}$. No ensaio de $50 \mathrm{kPa}$, há presença de lineações e mudanças na foliação da amostra tanto no entorto quanto no interior do plano de ruptura. No 
ensaio de $100 \mathrm{kPa}$, há maior presença de fissuras, associadas à de zonas de cisalhamento conjugadas menores, formadas anteriormente ao deslocamento principal. Estas zonas de cisalhamento apresentam relações estruturais correlacionáveis com o esquema de Riedel.

- Já há formação de plano de ruptura próximo ao pico de tensão desviadora. Porém, o plano apresenta-se pouco desenvolvido, com pequena espessura e sem evidências de deslocamento significativo. Não interferindo na estimativa dos parâmetros de resistência do solo.

A partir das dificuldades de interpretação dos ensaios triaxiais convencionais ocorridas devido a elevada heterogeneidade conclui-se que:

- Ensaios triaxiais convencionais realizados sem um bom controle da amostragem podem não resultar em valores com boa representatividade, devido a necessidade de interpolação de dados em amostras diferentes.

- Em solos residuais cimentados, em casos onde não é possível realizar controle da amostragem pode ser preferível realizar ensaios multi-estágios, que utilizam apenas uma amostra e minimizam o efeito da variabilidade do solo. 


\section{REFERÊNCIAS BIBLIOGRÁFICAS}

ABEF - Associação Brasileira de Engenharia de Fundações e Serviços Geotécnicos (Org). ABEF Research on Foundation Engineering. In: XII ICSMF. 1989.

ABNT - Associação Brasileira de Normas Técnicas. NBR-6457: Amostras de Solos: Preparação para Ensaios de Caracterização e Compactação. Rio de Janeiro, 1984a. 9 p.

ABNT - Associação Brasileira de Normas Técnicas. NBR-6459: Solo Determinação do Limite de Liquidez. Método de ensaio. Rio de Janeiro, 1984d, 6 p.

ABNT - Associação Brasileira de Normas Técnicas. NBR-6508: Grãos de Solo que Passam na Peneira de 4,8 mm - Determinação da Massa Específica. Método de Ensaio. Rio de Janeiro. 1984b, 8 p.

ABNT - Associação Brasileira de Normas Técnicas. NBR-7180: Solo Determinação do Limite de Plasticidade. Método de ensaio. Rio de Janeiro, 1984e, $3 p$.

ABNT - Associação Brasileira de Normas Técnicas. NBR-7181: Solo - Análise Granulométrica. Método de Ensaio. 1984c, 13 p.

AHLGREN, S.G. The Nucleation and Evolution of Riedel Shear Zones in Porous Sandstone. Journal of Structural Geology, v.23, p.1203-1214. 2001.

BISHOP, A. W.; HENKEL, D.J. The Measurement of Soil Properties in the Triaxial Test. 2ed. London: Edward Arnold. 1962.

BLACK,D.K.; LEE, K.L. Saturating Laboratory Samples by Back Pressure. Journal of Soil Mechanics and Foundations, ASCE, v.99, n.1, p.75-93. 1973.

BLIGHT, G.E. Origin and Formation of Residual Soils. In: BLIGHT, G.E.; LEONG, E.C. (Org). Mechanics of Residual Soil. 2ª ed. London: CRC Press. 1997.

BRENNER, R.P.; GARGA, V.K., BLIGHT, G.E., Shear Strengh Behaviour and the Measurement of Shear Strengh in Residual Soils. In: BLIGHT, G.E.; LEONG, E.C. (Org). Mechanics of Residual Soil. 2ª ed. London: CRC Press. 1997. 
CAMUTI, K.S.; McGUIRE, P.T. Preparation of Polished Thin Sections from Poorly Consolidates Regolith and Sediment Materials. Sedimentary Geology, v.128, 1999. CRAWFORD, A; WYLIE, D. A Modified Multiple Failure State Triaxial Testing Method. Anais: 28th U.S. Symp. on Rock Mechanics, London, p.133-140, 1987.

DE BEER, E. E. The Cell Test. Geotechnique, v.2, n.2, p.162-172, 1950.

DRESS, R. Practical Applications of Soil Micromorphologty Sampling and Sample Preparation. Summary of Presentation: Soil Micromorphology Workshop, 1977. FERREIRA, S.M.R; CORREIA, A.G.; ROQUE, A.J. Strengh of Non- Traditional Granular Materials Assessed from Drained Multistage Triaxial Tests. Procedia Engineering, v.143, p.67-74, 2016.

FOSSEN, H. Geologia Estrutural. 2ª ed. São Paulo: Oficina de Textos, 2013.

GILLOT, J.E. Importance of Specimen Preparation in Microscopy. Soil Specimen Preparation for Laboratory Testing, ASTM - American Society for Testing and Materials, STP 599, p. 289-307, 1976.

GURGUEIRA, M. D. Correlação de Dados Geológicos e Geotécnicos da Bacia de São Paulo. 2013. 76 p. Dissertação de mestrado. Instituto de Geociências, Universidade de São Paulo, São Paulo, 2013.

GUZMÁN, G.G.C. Contribuição ao Estudo do Comportamento Geotécnico de um Solo Quasi-saturado. 2014. 229 p. Dissertação de Mestrado. Escola Politécnica da Universidade de São Paulo, São Paulo, 2014.

GYLLAND, A.S.; RUESLATTEN, H.; JOSTAD, H.P.; NORDAL, S. Microstructural Observations of Shear Zones in Sensitive Clay. Engineering Geology, v. 163, p.7588, 2013.

HEAD, H. K, Manual of Soil Laboratory: Effective Stress Tests. v.3, 2ed. London: John Wiley. 1998.

HO, D.Y.F.; FREDLUND, D.G. A Multi-stage Triaxial Test for Insaturated Soils. Geotechnical Testing Journal, v.5, n.1, p - 18-25, 1982.

HORMDEE, D.; KAIKEERATI, N.; ANGSUWOTAI, P. Evaluation on the Results of Multistage Shear Test. Int. Journal of Geomate, v.2, n.1, p.140-143, 2012. 
KENNEY, T.C.; WATSON, G.H. Multiple-stage Triaxial Tests for Determining c' e Ф' of Saturated Soil. Anais: 5th Intern. Conference on Soil Mechanics and Foundation Engineering, Paris, p.191-195, 1961.

KHOSRAVI, A.; ALSHERIF, N.; LYNCH, C.; McCARTNEY, J. Multistage Triaxial Testing to Estimate Effective Stress Relationships for Unsatured Compacted Soils. Geotechnical Testing Journal, v.35, n.1, 2011.

KIM, H. M.; KO, H.Y. Multistage Triaxial Testing of Rocks. Canadian Geotechnical Journal, v.2, n.2, p. 90-105,1979.

KONDNER, R.L. Hyperbolic Strees-Strain response, cohesive soils. Journal of Soil Mechanics and Foundation, v.89, n.1, p.115-143, 1963.

KOVARI, K.; TISA, A.; EINSTEIN, H. H.; FRANKLIN, J.A. Suggested Methods for Determining the Strengh of Rock Materials in Triaxial Compression. Intern. Journal of Rock Mechanics and Min. Science, v. 20, n.6, p.283-290, 1975.

KUWAJIMA, R.M. Determinação da Sucção "in situ" em Solo Residual Compactado Utilizando-se o Parâmetro B e a Medição Direta de Sucção. 2000. 198 p. Dissertação de mestrado. Escola Politécnica da Universidade de São Paulo, São Paulo, 2000.

LAMBE, T.W. Stress Path Method. Journal of the Soil Mechanics and Foundations Division, v.93, n.6, p.309-331, 1967.

LEMOS, M.B,; MARINHO, F.A.M. Caracterização Geológico-Geotécnica do Solo Residual Proveniente de Gnaisses Migmatíticos do Complexo Embu, São Paulo, SP. Anais: XIX Congresso Brasileiro de Mecânica dos Solos e Engenharia Geotécnica, 2018.

LEROUIEIL, S.; VAUGHAN, P.R. The General and Congruent Effects of Structure in Natural Soils and Weak Rocks. Geotechnique, v.40, n.3, p.467-488, 1990.

LUMB, P. Multistage Triaxial Test on Undisturbed Soils. Civil Engineering Public Works Rev., v. 59, p. 591-595, 1964.

MONTEIRO, M.D.; GURGUEIRA, M.D.; ROCHA, H.C. Geologia da Região Metropolitana de São Paulo. In: ABMS (org). Twin Cities: Solos das Regiões Metropolitanas de São Paulo e Curitiba. 1 ed. São Paulo: ABMS, p. 15 - 43, 2012. 
MORGENSTERN, N.R.; TCHALENKO, J.S. Microscopic Structures in Kaolin Subjected to Direct Shear. Géotechnique, v. 17, p.309-328, 1967.

NAMBIAR, M.R.M.; RAO,G.V., GULHATI, S.K. Multistage Triaxial Testing: a Rational Procedure. Strengh Testing of Marine Sediments: Laboratory and In Situ Measurements, ASTM, STP 883, p.274-293, 1985.

OLIVEIRA, O.M. Estudo sobre a Resistência ao Cisalhamento de um Solo Residual Compactado não Saturado. 2004. Tese de doutorado. Escola Politécnica da Universidade de São Paulo, São Paulo, 2004.

ORLANDO, P.G. Avaliação Experimental da Interação Solo Coesivo-Fita Polimérica sob Condições de Teor de Umidade Variáveis. 2015. Tese de mestrado. Escola Politécnica da Universidade de São Paulo, São Paulo, 2015.

PAGOULATOS, A. Evaluation of Multistage Triaxial Testing on Berea Sandstone. Tese de Mestrado, University of Oklahoma, Normam, 2004.

PARRY, R.H.G.; NADARAJAH, V. Multistage Triaxial Testing of Lightly Overconsolidated Clays. Journal of Testing and Evaluation, v.1, n.5, p.347-391, 1973.

PINTO, C. S. Curso Básico de Mecânica de Solos. $3^{a}$ ed. São Paulo: Oficina de Textos, 2006.

RAHARDJO, H; LIM, T.T.; CHANG, M.F.; FREDLUND, D.G. Sher-Strengh Characteristics of a Residual Soil. Canadian Geotechnical Journal, v.32, n.1, p. 6077,1995 .

SAEEDY, H. S.; MOLLAH, M.A. Application of Multistage Triaxial Test to Kuwaiti Soils. ASTM - American Society for Testing and Materials, STP 977, p.363-375, 1988.

SCHOENEMANN, M.R.; PYLES, M.R. Stress Path Considerations in Multistage Triaxial Test. ASTM - American Society for Testing and Materials, STP 977, p.732739, 1988

SHARMA, M.S.R.; BAXTER, C.D.P.; MORAN, K.; VAZIRI, H.; NARAYANASAMY, R. Strengh os Weakly Cemented Sands from Drained Multistage Triaxial Tests. Journal of Geotechnical and Geoenvironmental Engineering. American Society of Civil Engineers, p. 1202-1210, 2011. 
SHIELDS, D.H.; DOMASCHUK, L.; MAN, C,-S, KENYON, R.M. The Deformation Properties of Warm Permafrost. Strengh Testing of Marine Sediments: Laboratory and In Situ Measurements, ASTM, STP 883, p.473-486, 1985.

SKEMPTON, A.W. Residual Strengh of Clays in Landslides, Folded Strata and the Laboratory. Géotechnique, v.35, n.1, p.3-18. 1985.

SRIDHARAN, A.; NARASIMHA RAO, S. A New Approach to Multi-Stage Triaxial Test. Journal of Soil Mechanics and foundation Div., v. 98, n.11, p.1279-1286, 1972.

STUERMER, M. M. Estudo da Capacidade de Retenção de Água em um Solo Residual Compactado. 1998. 158 p. Dissertação de mestrado. Escola Politécnica da Universidade de São Paulo, São Paulo, 1998.

TAYLOR, D.W. Triaxial Testing of Soils and Bituminous Mixtures. ASTM - American Society for Testing and Materials, STP 106, p. 180-191, 1950.

TCHALENKO, J. S. The Evolution of Kink-Bands and the Development of Compression Textures in Sheared Clays. Tectonophysics. v.6, n.2, p.159-174, 1967.

TCHALENKO, J.S. Similarities Between Shear Zones of Different Magnitudes. Geological Society of America Bulletin, v. 81. p. 1625-1640. 1970.

VAZ, L.F. Classificação Genética dos Solos e dos Horizontes de Alteração de Rocha em Regiões Tropicais. Solos e Rochas. v.19, n.2, p.117-136, 1996.

VIEIRA, A. M. Variação Sazonal da Sucção em um Talude de Solo Residual de Gnaisse. 1999. Dissertação de mestrado Escola Politécnica da Universidade de São Paulo, São Paulo, 1999.

WEN, B.P.; AYDIN, A.; Microstructural Study of a Natural Slip Zone: Quantification and Deformation History. Engineering Geology. v.68, p.289-317, 2002.

WONG, H.Y. Soil Strengh Parameter Determination. Hong Kong Engineer, The Journal of Hong Kong Institution of Engineers, p.33-39, 1978. 


\section{ANEXO A}

FOTO-MOSAICOS DAS ZONAS DE CISALHAMENTO OBSERVADAS EM MEV 


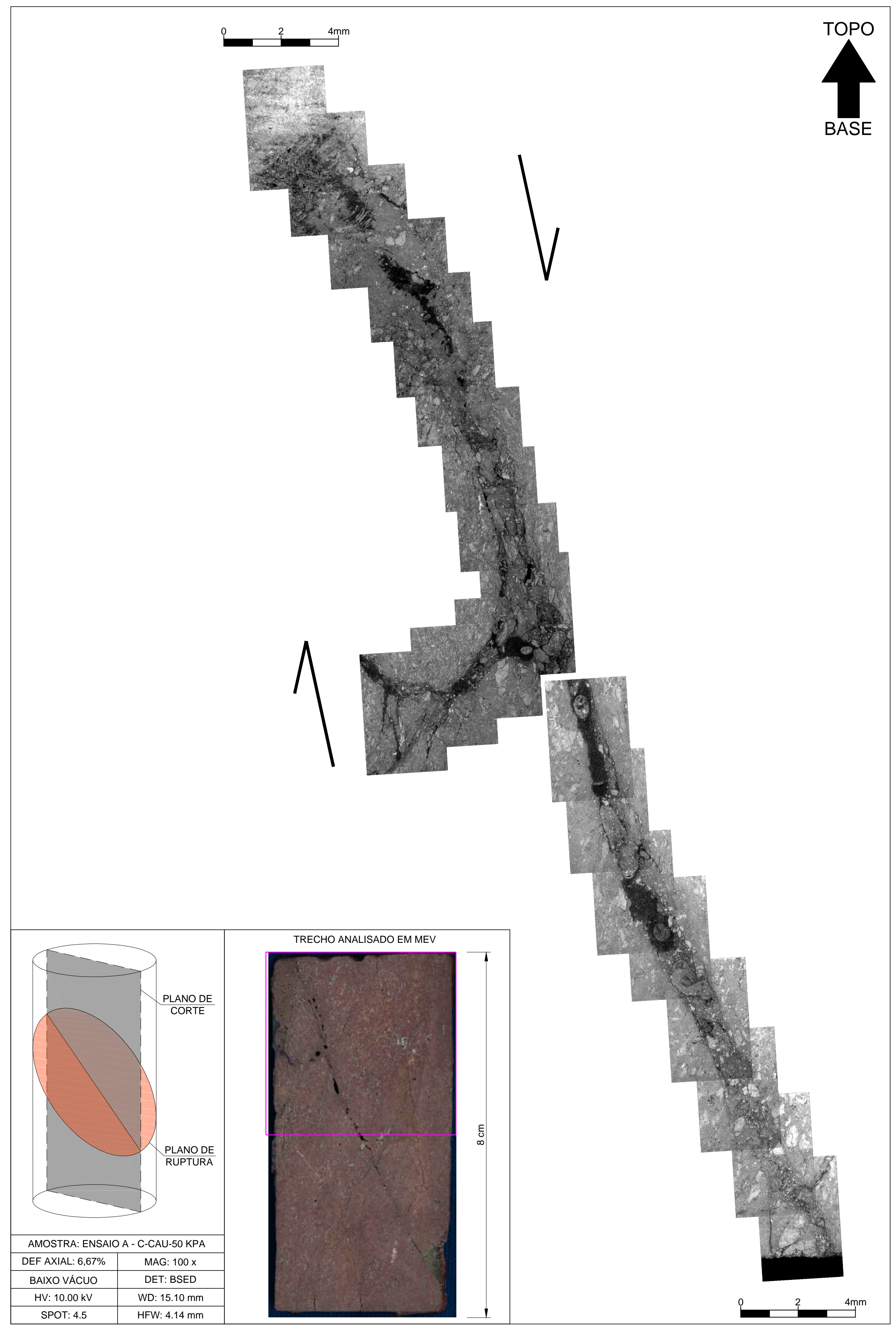




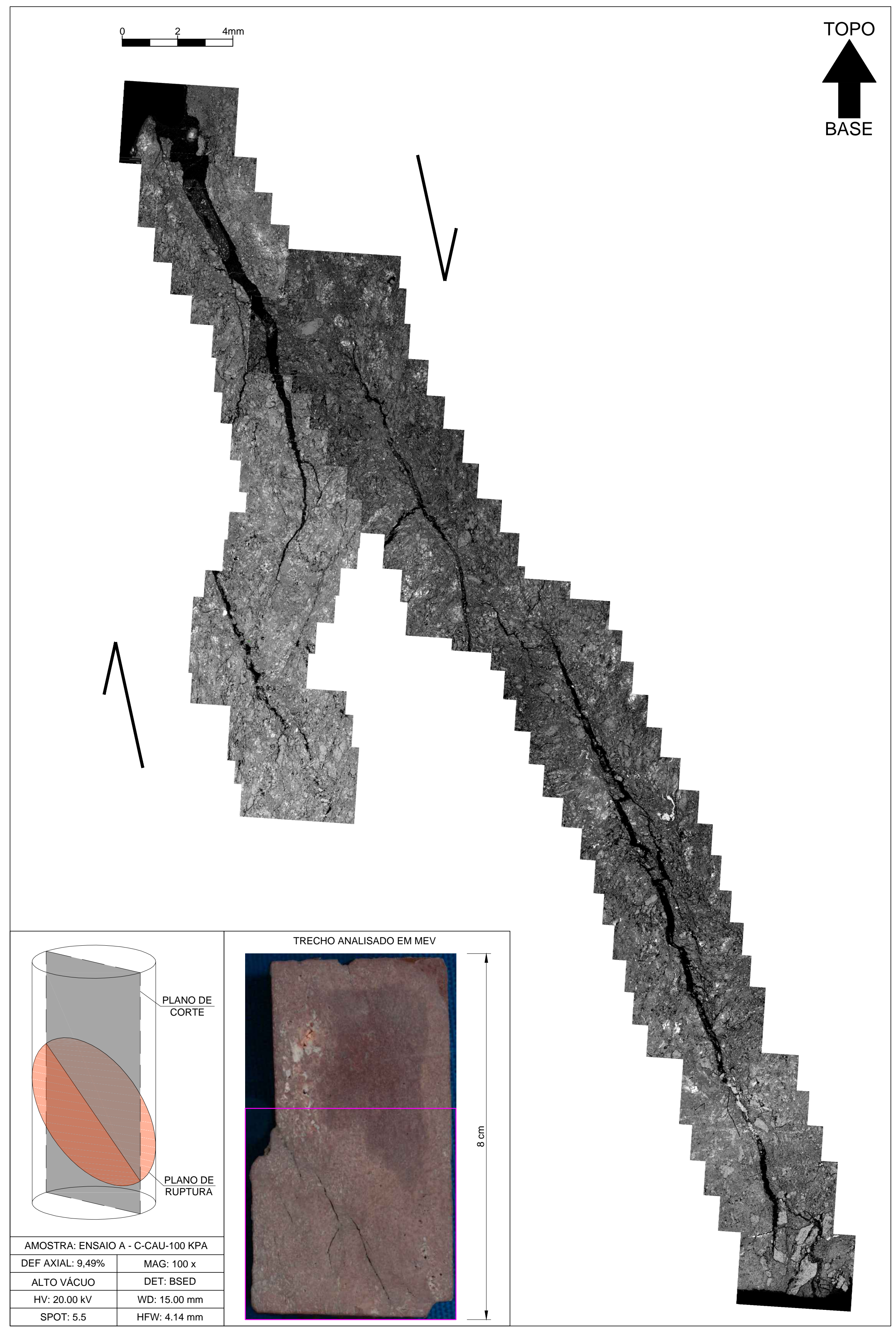




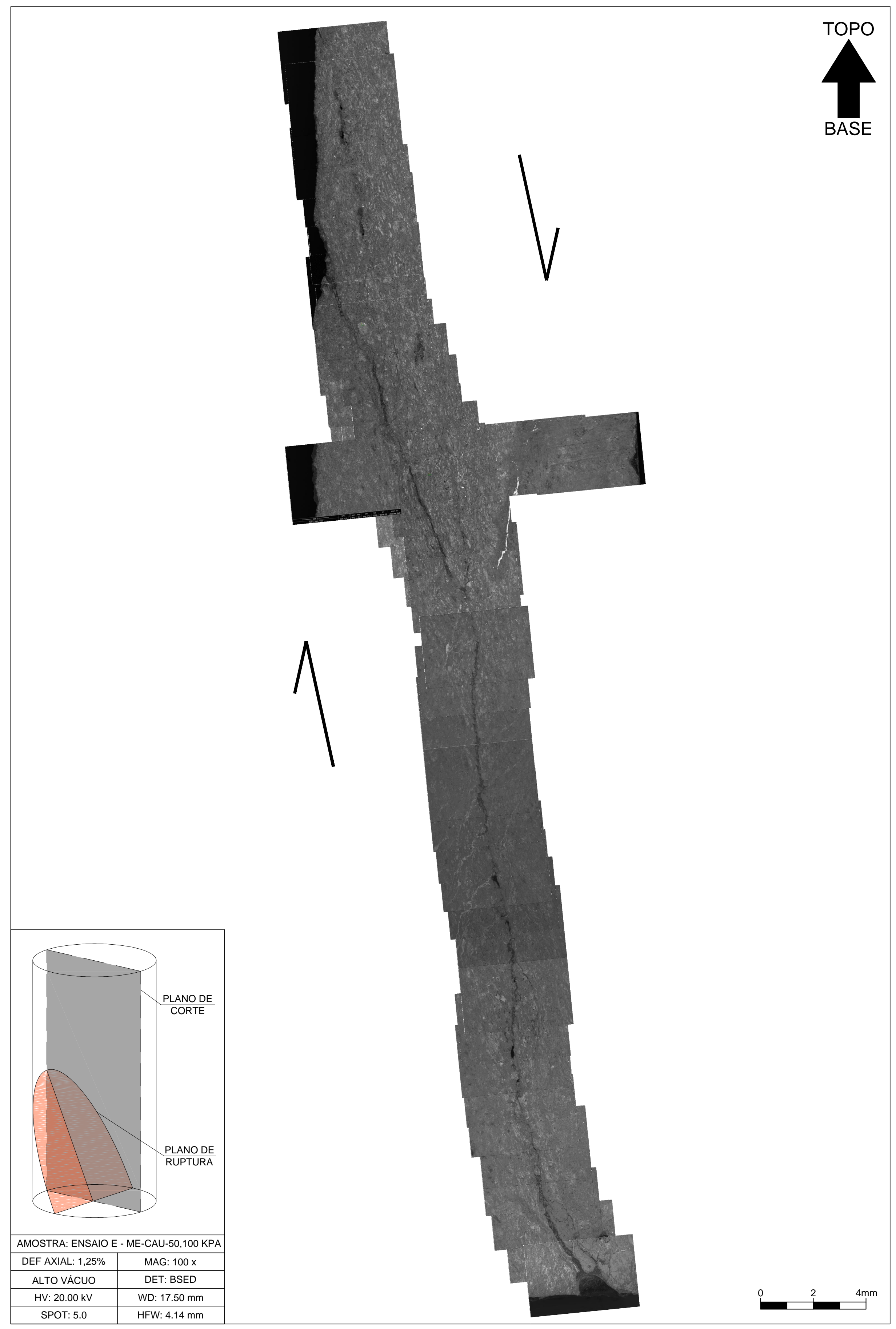




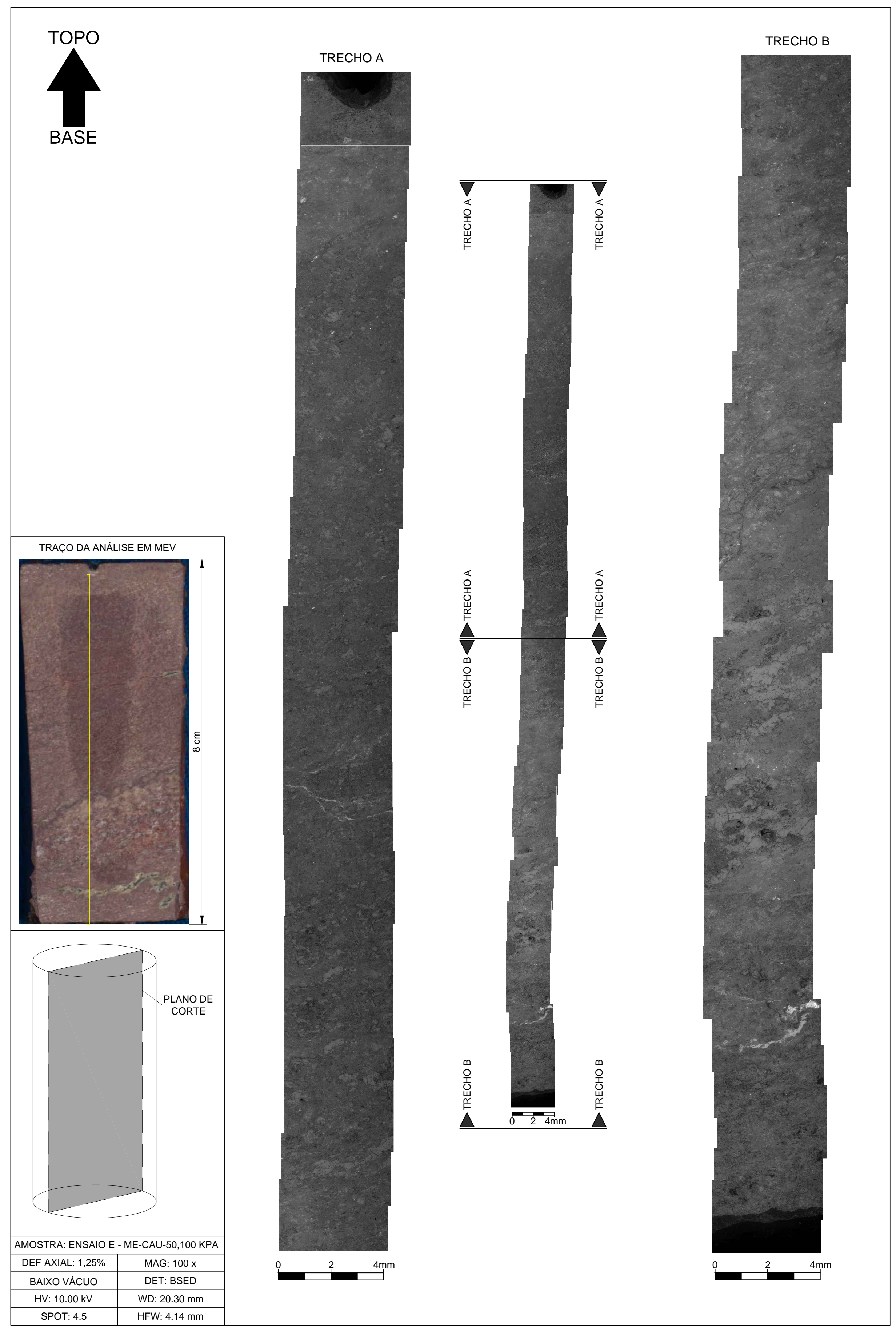

